\title{
WestVirginiaUniversity
}

THE RESEARCH REPOSITORY @ WVU

Graduate Theses, Dissertations, and Problem Reports

2016

\section{Three Essays on the Economics of Corruption}

Jamie Bologna

Follow this and additional works at: https://researchrepository.wvu.edu/etd

\section{Recommended Citation}

Bologna, Jamie, "Three Essays on the Economics of Corruption" (2016). Graduate Theses, Dissertations, and Problem Reports. 5229.

https://researchrepository.wvu.edu/etd/5229

This Dissertation is protected by copyright and/or related rights. It has been brought to you by the The Research Repository @ WVU with permission from the rights-holder(s). You are free to use this Dissertation in any way that is permitted by the copyright and related rights legislation that applies to your use. For other uses you must obtain permission from the rights-holder(s) directly, unless additional rights are indicated by a Creative Commons license in the record and/ or on the work itself. This Dissertation has been accepted for inclusion in WVU Graduate Theses, Dissertations, and Problem Reports collection by an authorized administrator of The Research Repository @ WVU.

For more information, please contact researchrepository@mail.wvu.edu. 


\title{
Three Essays on the Economics of Corruption
}

\author{
Jamie Bologna
}

Dissertation Submitted to the

College of Business and Economics at

West Virginia University

in partial fulfillment of the requirements for the degree of

Doctor of Philosophy

In

Economics

\author{
Andrew T. Young, Ph.D., Chair \\ Joshua C. Hall, Ph.D. \\ Jac C. Heckelman, Ph.D. \\ Donald J. Lacombe, Ph.D. \\ Amanda Ross, Ph.D. \\ Department of Economics \\ Morgantown, WV \\ 2016
}

Keywords: corruption, growth, income levels, informal economy

Copyright @ 2016 Jamie Bologna 


\title{
Abstract \\ Three Essays on the Economics of Corruption
}

\author{
Jamie Bologna
}

In this dissertation, I explore topics involving the measurement of political corruption and its effect on economic outcomes both across and within countries. The first chapter of this dissertation provides an introduction to the economics of corruption and summarizes the crucial existing research. This chapter describes how this dissertation contributes to the existing research and provides an outline for the following chapters. Chapter 2 examines the conditional effect of corruption on growth across a sample of countries. In this second chapter, I argue that the effect corruption has on economic growth depends on the uncertainty involved. Employing data on a cross-section of counties, this paper uses an interaction between the frequency of bribery payments and the uncertainty regarding the delivery of the service in exchange for these bribes, to show that, overall, corruption has a negative impact on growth, unless the uncertainty is minimal. Chapter 3 examines the effect of corruption and informal sector employment on income across 476 Brazilian municipalities to estimate whether corruption impacts GDP or income levels once variation in informal economic activity is taken into account. Overall, I find that higher levels of corruption and a larger informal economy are generally associated with poor economic outcomes. However, only the size of the informal economy has a statistically significant effect. Chapter 4 examines the most commonly used measure of corruption in the U.S. and shows how this measure is influenced by political factors. Lastly, Chapter 5 summarizes the findings from Chapter 2 through Chapter 4. Additionally, Chapter 5 discusses policy recommendations and future research projects involving the economics of corruption. 


\section{Dedication}

To my father and mother for their unwavering support and encouragement throughout my life. 


\section{Acknowledgements}

I would like to first thank my dissertation committee for all of their helpful comments, constructive critiques, and positive encouragement throughout not only my dissertation writing stages, but my entire career as a graduate student. I am particularly thankful to my advisor, Dr. Andrew Young, for his guidance, mentorship, and genuine advice. Dr. Young gave me the freedom to explore topics on my own, while providing continuous feedback, which taught me how to effectively engage in research. I am truly fortunate to have had the opportunity to work with Dr. Young as a graduate student, and only hope I can become a scholar of the same caliber someday. I am also grateful to Dr. Joshua Hall, Dr. Amanda Ross, and Dr. Donald Lacombe. I have learned an immense amount from all three professors as I taken classes and have coauthored papers with each. I would also like to thank Dr. Jac Heckelman for all of his helpful feedback on my work throughout the past few years. I was fortunate to meet Dr. Heckelman at an academic conference early on in my career as a graduate student. I am thankful for the time he has taken to read my work and provide invaluable advice.

I would also like to thank my fellow classmates for their support and encouragement along the way, as well as the lasting friendships we have formed. I am also grateful to my undergraduate advisors, Dr. Todd Nesbit and Dr. Kerry Adzima, for the time they have taken over the past nine years to support me and their genuine interest in my success. Lastly, I would like to thank my fiancé, Blake Pavlik, for his unwavering support, patience, and encouragement throughout my graduate career. Completing my $\mathrm{Ph} . \mathrm{D}$. would have proven difficult, if not impossible, without his support. 


\section{Table of Contents}

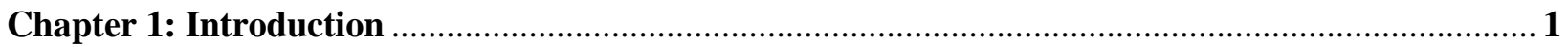

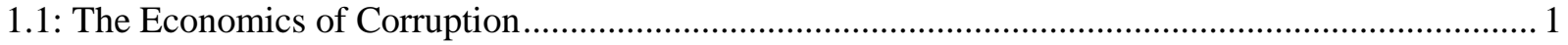

1.2: Dissertation Contributions and Outline........................................................................................ 4

Chapter 2: Corruption: The Good, the Bad, and The Uncertain ............................................... 10

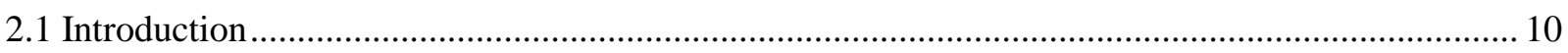

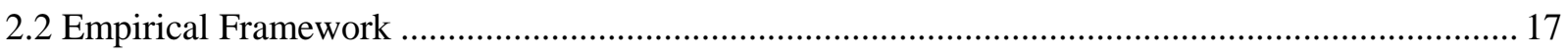

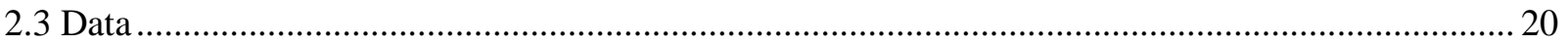

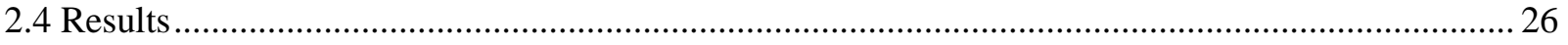

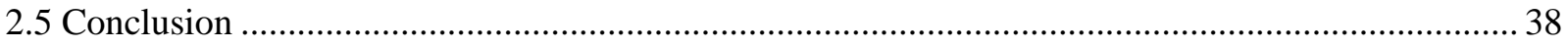

Chapter 3: The Effect of Informal Employment and Corruption on Income Levels in Brazil ......... 40

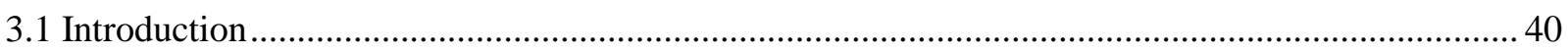

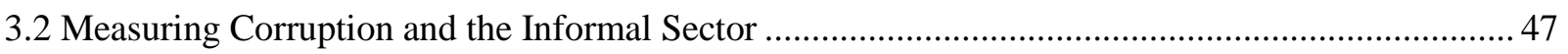

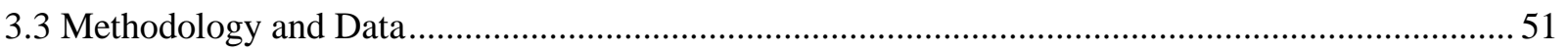

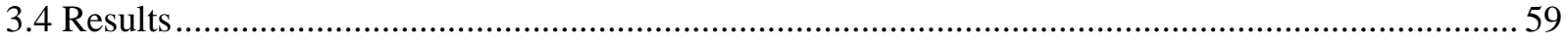

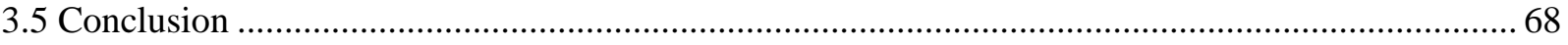

Chapter 4: Executive Influence over Reported Corruption Convictions: Are Conviction Rates a Biased Measure of State Level Corruption?.............................................................................. 70

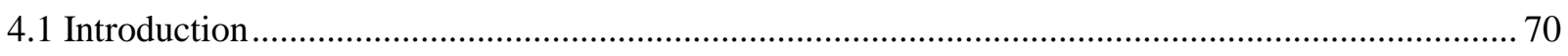

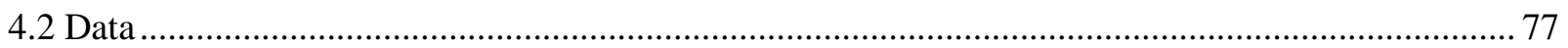

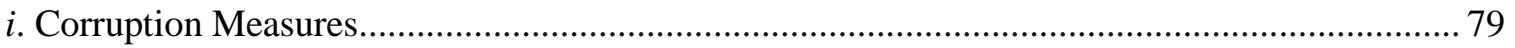

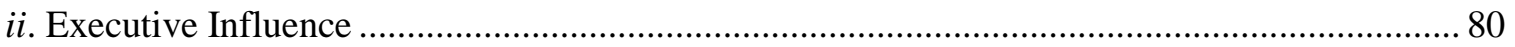

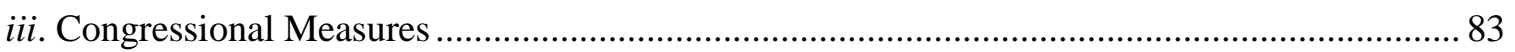

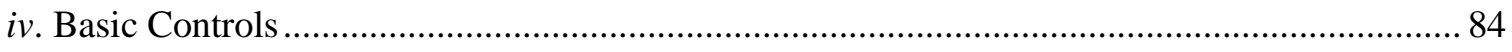

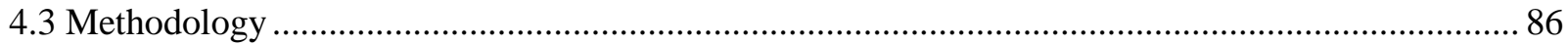

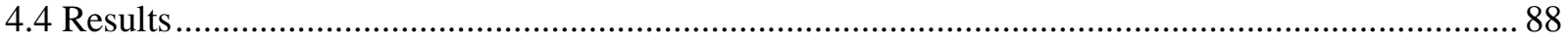

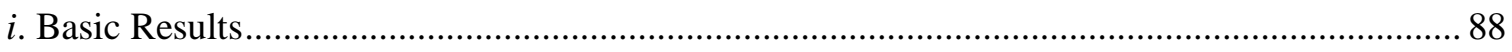

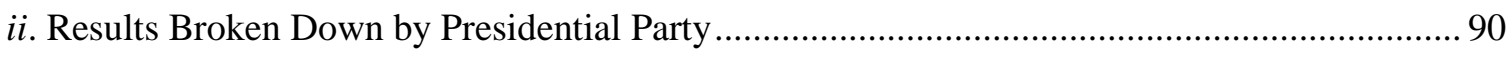

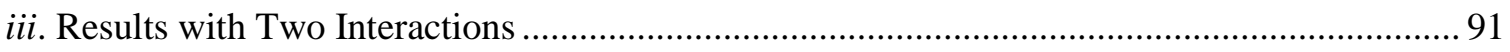

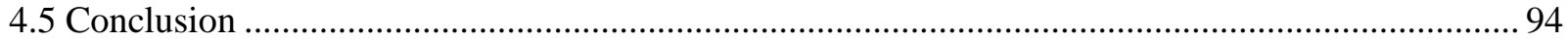

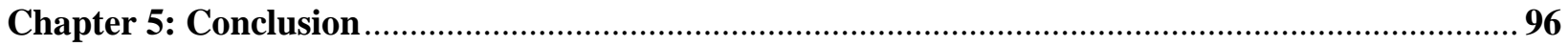

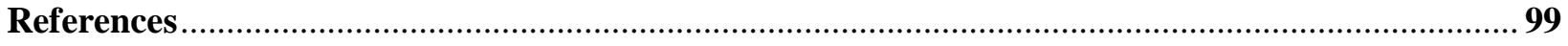

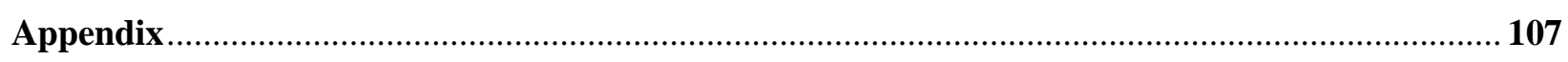

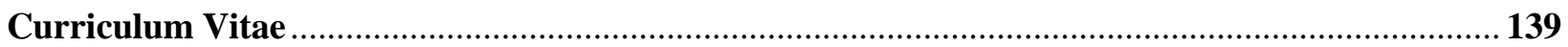




\section{List of Tables}

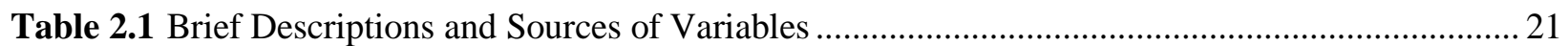

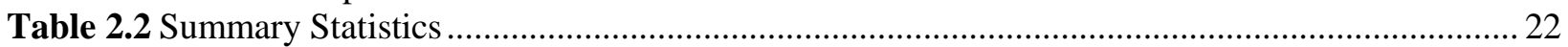

Table 2.3 Effect of corruption perceptions (CORRUPT_PER_1;CORRUPT_PER_2) versus frequency of corruption experience (CORRUPT_EXP) on average GDP per-capita growth; baseline specification ..... 28 Table 2.4 Effect of perceptions (CORRUPT_PER_1; CORRUPT_PER_2) versus frequency of corruption experience (CORRUPT_EXP) on average GDP per-capita growth; basic controls included ..................................2 29

Table 2.5 Conditional marginal effect of both corruption experience (CORRUPT_EXP) on growth ...... 29

Table 2.6 Effect of corruption experience (CORRUPT_EXP) on average GDP per-capita growth; comparing the importance of FREEDOM and UNCERT …............................................................ 33

Table 2.7 Conditional marginal effect of both corruption experience (CORRUPT_EXP) on growth from 2000-2005, holding economic freedom and uncertainty at given values ............................................... 34 Table 2.8 Conditional marginal effect of both corruption experience (CORRUPT_EXP) on growth from 2000-2011, holding economic freedom and uncertainty at given values .............................................. 35 Table 2.9 Effect of frequency of corruption experience (CORRUPT_EXP) on average GDP per-capita growth; basic controls included; IV robustness checks ........................................................................... 36

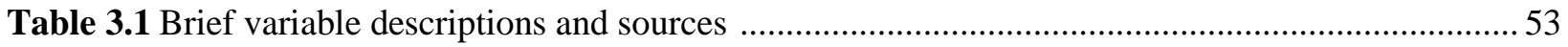

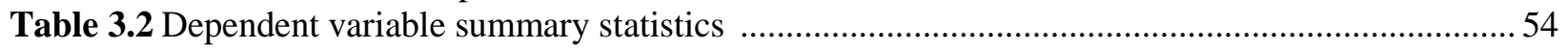

Table 3.3 Independent variable and instrumental variable brief descriptions .......................................55

Table 3.4 Independent variable and instrumental variable summary statistics ......................................56

Table 3.5 The effect corruption and the informal economy have on GDP per-capita in 2004 and income per-capita from different sources in 2000; no additional controls included ..........................................59

Table 3.6 The effect corruption and the informal economy have on GDP per-capita and income per-capita from different sources in 2010; no additional controls included ............................................................6 60

Table 3.7 The effect corruption, measured by the share of resources (R\$) found to involve corruption, and the informal economy have on GDP per-capita in 2004 and income per-capita from different sources in

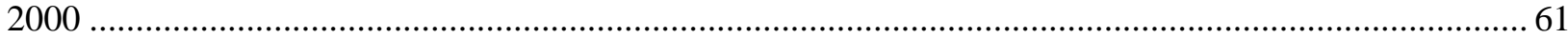

Table 3.8 The effect corruption, measured by the share of items found to involve corruption, and the informal economy have on GDP per-capita and income per-capita from different sources in 2000.......... 62 Table 3.9 The effect corruption, measured by the share of resources (R\$) found to involve corruption, and the informal economy have on GDP per-capita and income per-capita from different sources in $2010 \ldots . .63$ Table 3.10 The effect corruption, measured by the share of items found to involve corruption, and the informal economy have on GDP per-capita and income per-capita from different sources in 2010......... 64 Table 3.11 The effect corruption and the informal economy have on GDP per-capita and total income

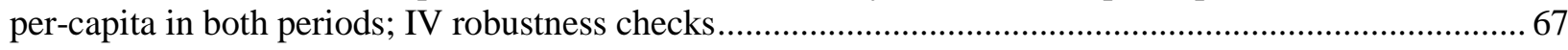

Table 4.1 Testing for differences in the means in PIN corruption data ............................................... 74

Table 4.2 Summary Statistics of Corruption Measures (Dependent Variables) \& Political Influence

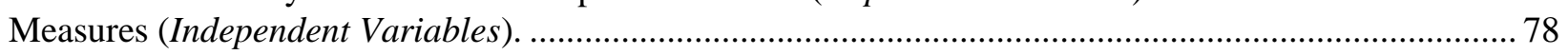

Table 4.3 Summary Statistics and brief variable descriptions of basic controls ................................... 78

Table 4.4 The effect of political importance and oversight committee membership on PIN measures of corruption

Table 4.5 The effect of political importance and oversight committee membership on PIN measures of corruption, split into two samples based on president's political party

Table 4.6 The effect of political importance and oversight committee membership on PIN measures of corruption, split into two samples based on whether PERCENT_DEM - .50 is positive or negative 
Table 4.7 The effect political importance and oversight committee membership conditional on being the same party as the president on corruption convictions 92

Table 4.8 Conditional marginal effect of IMPORTANCE on corruption convictions, holding COMMITTEE_MAJ_PRES and SAME_PARTY_AS_PRES at given values 93

Table 4.9 Conditional marginal effect of IMPORTANCE on corruption conviction rates, holding COMMITTEE_MAJ_PRES and SAME_PARTY_AS_PRES at given values 


\section{List of Figures}

Figure 2.1 Effect of interaction between frequency of corruption experience and corruption uncertainty on average GDP per-capita growth rate for 2000-2005 and 2000-2011 periods

Figure 2.2 Effect of interaction between frequency of corruption experience and corruption uncertainty on average GDP per-capita growth rate for 2000-2005 and 2000-2011 periods

Figure 2.3 Estimated marginal impacts of corruption experience (CORRUPT_EXP) on growth, conditional on the level of uncertainty (UNCERT) for the 2000-2005 period (panel a) and the 2000-2011 period (panel b).

Figure 3.1The relationship between corruption, as measured by the share of resources $(\mathrm{R} \$$ ) found to involve corruption, and formal and informal incomes per-worker.

Figure 3.2 The relationship between corruption, as measured by the share of resources (R\$) found to involve corruption, and the size of the informal economy is 2000 .

Figure 3.3 The relationship between the size of the informal economy in 2000 and formal and informal incomes per-worker in 2000 .

Figure 4.1 Map of Political Importance across the 48 Contiguous U.S. States. 


\section{Chapter 1}

\section{Introduction}

\subsection{The Economics of Corruption}

Public corruption, commonly defined as "the misuse of public office for private gain" (Svensson, 2005 , p. 20), is considered to be a major detriment to development, particularly in low-income countries. Corruption not only poses direct costs on society through the act of bribing, it also results in the misallocation of productive resources (Svensson, 2005). For example, even if corruption 'greases the wheels' of an economy by allowing more firms to operate (Dreher and Gassebner, 2013), it is possible that the firms allowed to operate are the least efficient. A more specific example of this is when the government is looking to contract the production of a good to a private company, a firm may gain the government's contract through bribes. However, the firm may pay to gain this contract at the expense of the quality of their product (Rose-Ackerman, 1996).

The World Bank has supported over 600 anti-corruption and governance initiatives developed by member countries since 1996 and has launched the Strengthening World Bank Group Engagement on Governance and Anticorruption (GAC) strategy in 2007. The GAC strategy has been recently updated in 2012, making GAC an integral part of the Bank's operations. $^{1}$ Other international organizations, for example the Organization for Economic Cooperation and Development (OECD) and United Nations (UN), also pursue anti-corruption

\footnotetext{
${ }^{1}$ In an effort to give an approximation of the importance of corruption, the World Bank Institute estimated that worldwide total bribery alone is about $\$ 1$ trillion per year (Kaufmann, 2005). A common definition of corruption is the abuse of public office for private gain (World Bank, Rose-Ackerman (2004)). Since bribery is just one form of corruption it is likely to be an underestimate of the true cost of corruption.
} 
initiatives, such as the OECD's Anti-Bribery Convention and the UN's Convention against Corruption (UNCAC).

Despite these massive anti-corruption efforts, empirical evidence regarding the economic consequences of corruption is mixed. Beginning with Mauro (1995), several studies report a negative relationship between corruption and economic growth ( $\mathrm{Li}, \mathrm{Xu}$, and Zou, 2000; Abed and Davoodi, 2002). However, other studies find that this negative relationship disappears once other factors are controlled for (Mo, 2001; Mocan, 2004; Mocan, 2009). A major goal of my dissertation research is to understand why scholars are getting these mixed results, when the idea that corruption has a negative effect is so prominent. This will shed more light on the nature and measurement of corruption.

Importantly, many of the holes in the existing literature stem from the fact that, due to its secretive nature, corruption is extremely hard to measure. One of the goals of this dissertation is to get a better understanding of the effects political corruption has on economic outcomes using improved measures. Another goal is to better understand the most commonly used measures of corruption so that researchers can make more careful conclusions from their research.

One key factor that is missing in much of the cross-country research is the uncertainty involved in corruption. Corruption regimes differ greatly across countries, causing the uncertainty involving corruption to vary greatly as well. Shleifer and Vishny (1993) argue that there are ostensibly three different types of corruption regimes. The first two regimes both involve monopolistic providers, however end up with very different uncertainty levels. The first is one in which there is a monopoly over the goods to be provided and to whom bribes should be paid is therefore clear. The second is one in which an individual may need numerous complementary goods that come from several different monopolistic providers resulting in 
significantly more uncertainty. In order to make the comparison between these two types of regimes concrete, Shleifer and Vishny (1993) compare Communist Russia with post-Communist Russia, arguing significantly more uncertainty exists regarding corruption in the latter. A third regime exists as well, however, in this regime competition exists among suppliers of the same goods, causing both the level of corruption and uncertainty to fall since individuals can simply switch providers if unsatisfied with the current service. In the second chapter of this dissertation I explore how the level of uncertainty determines corruption's impact on economic growth.

While there are two important aspects of uncertainty that surround corruption, from uncertainty regarding the requirement of bribery to uncertainty regarding the success of bribery, the second chapter of my dissertation will focus on the latter as this directly tests whether or not corruption represents a mutually beneficial transaction or a simple transfer of wealth. In regimes where bribery "works", for example, corruption will likely have less of a negative impact as it acts as a mutually beneficial transaction and the firm got something beneficial for its bribery payment. Consequently, while institutional quality may be important in determining the overall level of corruption, it seems that uncertainty is the crucial determinant of how corruption will impact growth. Overall, I find that corruption has a negative impact on growth, unless the uncertainty is minimal. Furthermore, the negative effect of corruption becomes larger in magnitude with higher levels of uncertainty.

Another key factor missing from the empirical corruption-income literature is the informal sector. It could be the case that we see a negative correlation between low-income countries and high corruption levels partly because corruption is driving individuals to participate in the informal sector, seemingly lowering income and GDP per-capita due to its negative impact on the formal economy alone. Chapter 3 explores this hypothesis using data 
from Brazilian municipalities. Overall, I find that higher levels of corruption and a larger informal economy are generally associated with poor economic outcomes. However, only the size of the informal economy has a statistically significant effect.

Lastly, though the corruption measure used in Chapter 3 provides an excellent example of an unbiased, instance based, corruption measure, this measure is specific to Brazil. In most cases, researchers are forced to rely on alternative, less reliable measures of corruption. I explore the reliability of one of these measures in Chapter 4. Most US state level studies use data on federal corruption convictions from reports by the US Department of Justice's (DOJ) Public Integrity Section (PIN) to measure corruption. This data may be problematic for two reasons. First, research has shown that the presidentially appointed federal prosecutors handling a majority of corruption cases tend to make decisions on which cases to take to court based on partisan ties (Gordon, 2009), resulting in a potential bias of corruption convictions. Second, few studies that use the PIN data acknowledge that it is derived from a survey of US Attorneys and not from administrative records (Boylan and Long, 2003; Cordis and Milyo, 2013). Therefore, the PIN data is derived from a survey of US Attorneys that have been shown to exhibit a bias in the actual decision to take trials to court. Thus, the PIN data is likely inaccurate, and more importantly, politically biased. Additionally, we may see that politicians in politically important states are more inclined to engage in corruption because the returns to doing so are much higher. I find evidence that reported corruption convictions vary systematically based on political factors.

\subsection{Dissertation Contributions and Outline}

This dissertation includes three essays on the economics of corruption. Chapter 2 and Chapter 3 both focus on corruption's effect on economic outcomes. Chapter 2 shows that this effect 
depends on the level uncertainty regarding the corrupt acts across countries. Chapter 3 looks within the country of Brazil to show that the informal sector actually has a more robust negative effect on income levels that corruption alone. Chapter 4 takes a different approach and examines the reliability of a commonly used existing measure of corruption, corruption convictions.

The second chapter of my dissertation argues that the effect corruption has on economic growth may depend on the uncertainty involved. More specifically, I argue that the mixed results of the above empirical studies stem from the fact that uncertainty associated with the secretive nature of corruption is not controlled for. Using an interaction term between the experience of corruption and uncertainty regarding corruption, I find that corruption generally has a negative impact on growth, unless there is a minimal amount of uncertainty. Furthermore, the negative effect of corruption becomes larger in magnitude with higher levels of uncertainty.

As mentioned above, Shleifer and Vishny (1993) argue that there are ostensibly three different types of corruption regimes, with the interesting comparison being between the regimes both with monopolistic providers. Recall the first regime is one in which there is a monopoly over the goods to be provided and to whom bribes should be paid is therefore clear; while in the second regime, an individual may need numerous complementary goods that come from several different monopolistic providers making bribe payments unclear. In both of these regimes we are likely to see a significant amount of corruption. However, in the first regime the effect corruption has on economic outcomes is likely to be less detrimental than in the second simply because it is more predictable. In addition, the second regime is more susceptible to rent-seeking activities that further increase uncertainty. As argued in Shleifer and Vishny (1993), in the second regime incentives often exist to set up new government organizations that create new laws and regulations simply to enable the officials in these organizations to become a provider of some 
government good or service and extract bribes. As predicting what new laws or regulations will be set in place is difficult (if not impossible), this greatly increases uncertainty and decreases incentives for investment.

Further, given that the second regime is more susceptible to rent-seeking activities, it is likely that firms in this second regime are even more inefficient than the first. Dal Bó and Rossi (2007) argue that a high level of corruption is associated with more inefficient firms since corruption encourages firms to allocate more resources away from productive activities to lessproductive activities, one of these activities being rent-seeking. Consequently, countries that have an environment resembling the second regime may have lower growth rates simply because their firms as a whole are less efficient.

Chapter 2 uses questions from the World Bank’s World Business Environment Survey (WBES) to conduct a cross-sectional analysis of the effect corruption experience, uncertainty, and an interaction between corruption experience and uncertainty have on economic growth. This interaction term will be used to determine if the effect corruption has on growth is contingent upon the uncertainty involved. To the best of my knowledge, this is the first paper to do so.

As a preview of the results, Chapter 2 finds that over a five year period, the marginal effect of an increase in the frequency of corruption experience has a statistically significant and positive relationship with economic growth at extremely low levels of uncertainty. However, the sign of this effect becomes negative for a majority of the sample. Over an eleven-year period, however, more uncertainty is tolerated and the positive and statistically significant effect of corruption is relevant for $30 \%$ of the sample. However, the sign of this effect becomes negative for over $58 \%$ of the sample and statistically significant and negative for over $40 \%$ of the sample. 
Furthermore, in both periods, the negative effect of corruption becomes larger with more uncertainty. Further, given the potential endogeneity between corruption and economic growth, I use latitude and government consumption as a share of GDP to instrument for corruption. Thus overall, Chapter 2 finds that corruption has a negative impact on growth, unless there is a minimal amount of uncertainty.

In Chapter 3, I test if corruption has a significant impact on income levels one variation in informal economic activity is taken into account. The Brazilian economy offers an ideal setting for this type of analysis. I find that the informal sector is more important in determining well-being than corruption. This is therefore suggesting that corruption may impact income levels through its effect on the informal sector.

The negative association between corruption and income levels is well-documented, and numerous papers also link corruption to the size of the shadow economy (Johnson et al., 1997; Hindriks et al., 1999; Hibbs and Piculescu, 2005; Dreher et al., 2009; Dreher and Schneider, 2010). However, empirical studies that explicitly incorporate the effect of the informal sector when estimating the relationship between corruption and economic outcomes at the aggregate level are scarce and there are virtually no studies that incorporate this effect within a specific country. For example, broad surveys of the corruption literature rarely even mention the informal sector, other than the fact that its size may be influenced by corruption (e.g., Dreher and Herzfeld, 2005; Treisman, 2007). Thus, if the informal sector has a significant impact on economic outcomes and if corruption and the informal sector are significantly correlated, then previous empirical results are potentially biased.

Overall, Chapter 3 finds that while corruption tends to have a negative association with GDP per-capita and income levels, this relationship is largely statistically insignificant. 
However, the size of the informal sector has a negative and robustly significant relationship with GDP per-capita and average income from all sources of employment (both formal and informal). This is therefore suggesting that the size of the informal sector may be more important in determining income levels than corruption. Furthermore, even if informal employment is a relevant alternative to formal employment and results in positive spillovers into the formal economy, society as a whole is worse off in the face of a larger informal sector since both GDP per-capita and total incomes are lower.

In addition to exploring reasons behind the mixed results of the growth-corruption literature by looking at important omitted controls, I also explore the possibility that this corruption data is simply not telling us what we would like it to in Chapter 4. Focusing on corruption studies within the US states, I caution researchers in their use of federal corruption conviction rates as a measure of corruption across states. Federal corruption conviction rates are provided by the US Department of Justice's (DOJ) Public Integrity Section (PIN). This is the only freely available corruption measure available for the US that varies both across states and time. However, because corruption cases at all levels of government are overseen by PIN, estimates of corruption using corruption convictions are potentially biased. This is in fact what I find.

As part of the DOJ, PIN is an agency within the executive branch of the US federal government. Moreover, the head of the DOJ, the Attorney General, is appointed by the president and serves as a member of the president's cabinet. Thus, it is possible that the president exerts an influence over corruption convictions. For example, in states that are important to win in a presidential election, the president may have an incentive to sway its voters by influencing number of corruption convictions of officials in that state. For obvious reasons, this incentive is 
greater for presidents serving in their first term but will likely still exist during a second term to the extent that a president aims to help his or her political party to stay in power. Thus, the first goal of this paper is to estimate the impact of executive influence on federal corruption conviction rates across the US states.

Using state-level data on corruption convictions and political importance over five consecutive presidential terms from 1993-2012, Chapter 4 finds evidence that executive influence is an important determinant of reported federal corruption convictions in each state. Specifically, the evidence suggests that corruption conviction rates are higher in politically important states. However, this effect decreases in magnitude and becomes statistically insignificant when states have a governor of the same political party as the president. Thus, it seems that corruption convictions vary systematically based on political factors. 


\section{Chapter 2}

\section{Corruption: The Good, The Bad, and The Uncertain}

\subsection{Introduction}

The idea that corruption negatively impacts economic growth is widely held and acknowledged. The World Bank has supported over 600 anti-corruption and governance initiatives developed by member countries since 1996 and has launched the Strengthening World Bank Group Engagement on Governance and Anticorruption (GAC) strategy in 2007. The GAC strategy has been recently updated in 2012, making GAC an integral part of the Bank's operations. ${ }^{2}$ Other international organizations, for example the Organization for Economic Co-operation and Development (OECD) and United Nations (UN), also pursue anti-corruption initiatives, such as the OECD's Anti-Bribery Convention and the UN's Convention against Corruption (UNCAC).

Nevertheless, the empirical evidence regarding the economic consequences of corruption is mixed. Beginning with Mauro (1995), several studies report a negative relationship between corruption and economic growth (Li, Xu, and Zou, 2000; Abed and Davoodi, 2002). However, other studies find that this negative relationship disappears once other factors are controlled for (Mo, 2001; Mocan, 2004; Mocan, 2009).

This paper argues that the mixed results of the above empirical studies stem from the fact that uncertainty associated with the secretive nature of corruption is not controlled for. As argued in Shleifer and Vishny (1993), there are ostensibly three different types of corruption regimes.

One in which there is a monopoly over the goods to be provided and to whom bribes should be paid is therefore clear. Thus, while there may be a high level of corruption there is a low amount

\footnotetext{
${ }^{2}$ In an effort to give an approximation of the importance of corruption, the World Bank Institute estimated that worldwide total bribery alone is about $\$ 1$ trillion per year (Kaufmann, 2005). A common definition of corruption is the abuse of public office for private gain (World Bank, Rose-Ackerman (2004)). Since bribery is just one form of corruption it is likely to be an underestimate of the true cost of corruption.
} 
of uncertainty. In the second regime, however, an individual may need numerous complementary goods that come from several different monopolistic providers. In addition, all of these providers are attempting to maximize their own revenue rather than combined revenue, causing uncertainty regarding bribe payments to be extremely high. This uncertainty stems from the fact that in this second regime there are several different monopolistic providers that may or may not ask for bribe payments. Further, it is unclear as to what the exact amount of the payment will be, if a bribe payment is required. In order to make the comparison between these two types of regimes concrete, Shleifer and Vishny (1993) compare Communist Russia with post-Communist Russia, arguing significantly more uncertainty exists regarding corruption in the latter.

In the third regime, competition exists among suppliers of the same goods, causing both the level of corruption and uncertainty to fall since individuals can simply switch providers if unsatisfied with the current service. However, the interesting comparison is between the first and second regimes. In both of these regimes we are likely to see a significant amount of corruption. However, in the first regime the effect corruption has on economic outcomes is likely to be less detrimental than in the second simply because it is more predictable. In addition, the second regime is more susceptible to rent-seeking activities that further increase uncertainty. As argued in Shleifer and Vishny (1993), in the second regime incentives often exist to set up new government organizations that create new laws and regulations simply to enable the officials in these organizations to become a provider of some government good or service and extract bribes. As predicting what new laws or regulations will be set in place is difficult, this greatly increases uncertainty and decreases incentives for investment.

Further, given that the second regime is more susceptible to rent-seeking activities, it is likely that firms in this second regime are even more inefficient than the first. Dal Bó and Rossi 
(2007) argue that a high level of corruption is associated with more inefficient firms since corruption encourages firms to allocate more resources away from productive activities to lessproductive activities, one of these activities being rent-seeking. Consequently, countries that have an environment resembling the second regime may have lower growth rates simply because their firms as a whole are less efficient.

Thus, the regimes in which corruption takes place seem to determine whether corruption will be more or less uncertain. While there are two important aspects of uncertainty that surround corruption, from uncertainty regarding the requirement of bribery to uncertainty regarding the success of bribery, this paper will focus on the latter as this directly tests whether or not corruption represents a mutually beneficial transaction or a simple transfer of wealth. In regimes where bribery "works", for example, corruption will likely have less of a negative impact as it acts as a mutually beneficial transaction and the firm got something beneficial for its bribery payment. Consequently, while institutional quality may be important in determining the overall level of corruption, it seems that uncertainty is the crucial determinant of how corruption will impact growth.

This paper uses questions from the World Bank's World Business Environment Survey (WBES) to conduct a cross-sectional analysis of the effect corruption experience, uncertainty, and an interaction between corruption experience and uncertainty have on economic growth. This interaction term will be used to determine if the effect corruption has on growth is contingent upon the uncertainty involved. To the best of my knowledge, this is the first paper to do so.

There have been three studies showing that corruption has less of a negative impact on investment in regions where corruption is more predictable (Wei, 1997; Campos et al., 1999; 
Lambsdorff, 2003). Campos et al. (1999) and Lambsdorff (2003) use a measure of uncertainty that is similar to the one used in this paper. Both use a measure of uncertainty that comes from a survey of firms asking if the service was delivered as agreed. Campos et al. (1999) use an additional survey question asking if the additional payment was known in advance. Both find that corruption in regimes that have less uncertainty have less of a negative impact. However, both only control for the overall level of corruption and uncertainty involved, and do not allow for an interaction between the two.

Wei (1997) attempts to test the corruption-investment relationship by including an interaction term between uncertainty and corruption perceptions. However, the measure of uncertainty the author is using is from the 1997 Global Competitiveness Report where respondents were asked to rate the level of corruption according the extent of irregular or additional payments. Wei takes the standard deviation of this rating and then assumes the standard deviation of this response is correlated with other measures of uncertainty, such as if the service can be guaranteed after the bribe.

This paper expands upon all three studies by using economic growth, rather than investment, as the dependent variable. It is crucial to understand whether corruption, and the uncertainty associated with it, increase or decrease the standard of living of a country. The clearest way to test this hypothesis is by exploring the effect corruption has on economic growth. Using investment as a proxy for economic growth can be misleading as the empirical evidence exploring the links between growth and investment is mixed and extremely sensitive to the measure of investment.

For example, in regards to foreign direct investment (FDI), the measure used in Wei (1997), it may be the case that in some of these highly corrupt countries, increases in FDI may 
have no impact on economic growth. As shown in Borensztein, et al. (1998), FDI only increases productivity in host countries that are above a minimum threshold of capital stock. Even more extreme is the finding by Gourinchas and Jeanne (2013) that capital flows to countries that have lower growth rates, suggesting that looking at net capital inflows as in Lambsdorff (2003) may also be misleading for growth predictions. ${ }^{3}$

Unlike Wei (1997) and Lambsdorff (2003), Campos et al. (1999) consider domestic investment as a percent of GDP as the dependent variable. While including domestic investment can be seen as an improvement as it has been shown to be more strongly correlated with growth than foreign investment (Gourinchas and Jeanne, 2013), it still has its drawbacks. As shown in Choe (2003), economic growth tends to have a stronger impact on domestic investment than domestic investment has on growth.

In addition to altering the dependent variable, this paper expands upon the Wei (1997) study by using a more direct measure of corruption uncertainty, similar to the one in the Campos et al. (1999) and Lamsdorff (2003) studies, where it is specifically asking firms if the service was delivered as agreed after making an additional payment, i.e., a bribe. In addition, this paper expands upon Campos et al. (1999) and Lamsdorff (2003) by interacting this with the frequency the firms make these additional payments. By including the interaction term this paper will be able to properly estimate the marginal effects of an increase in corruption.

If the effect corruption has on growth is contingent upon the level of uncertainty involved, it is important to include and interpret an interaction between the two. Specifically, we want to know if uncertainty actually increases the negative impact of corruption on growth. Thus, not only is it important to know the overall effect of corruption on growth, holding

\footnotetext{
${ }^{3}$ It is important to note that the finding of Gourinchas and Jeanne (2011) is not driven by foreign aid flows, as aidadjusted capital flows show a similar pattern.
} 
uncertainty constant, but it is also important to know how the effect of corruption actually worsens as uncertainty increases. Therefore, this paper is directly testing the effects these bribes have on growth contingent upon whether the service the firm paid for was delivered as agreed.

This will give some indication of the levels of uncertainty that corruption has statistically significant impacts on growth and further, what the size and signs of these impacts are.

Figure 2.1: Effects of the frequency of corruption experience on average GDP per-capita growth rate for the 2000-2005 and 2000-2011 periods.
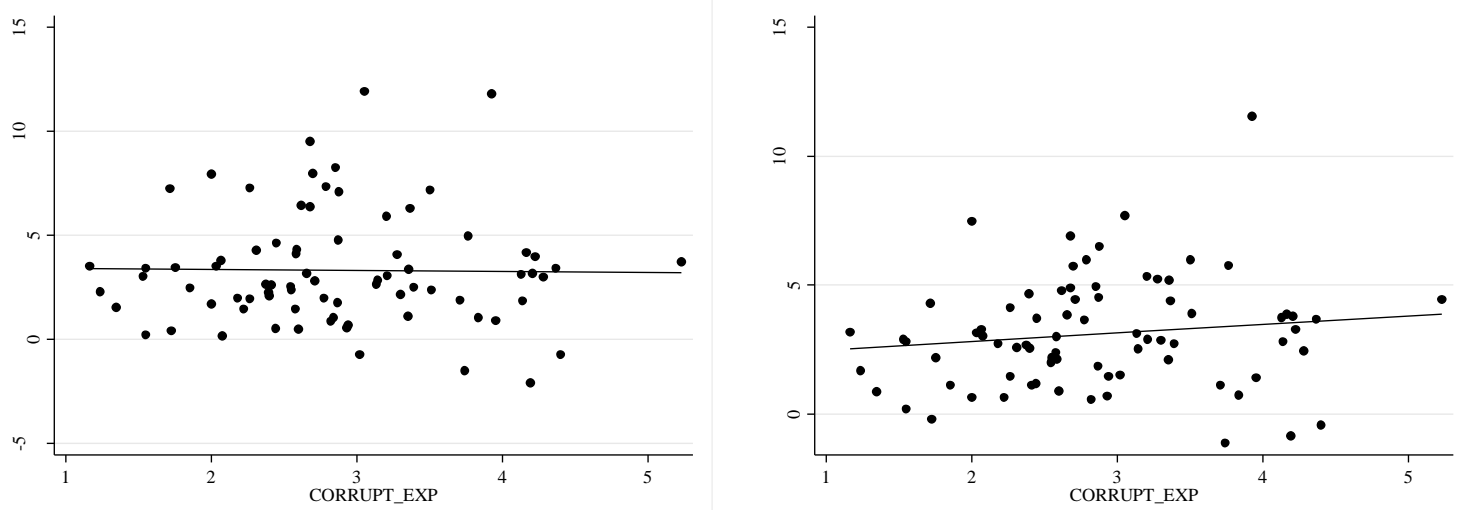

Source: World Business Environment Survey by the World Bank (CORRUPT_EXP) and World Bank Development Indicators $($ GROWTH).

Figure 2.1 plots the unconditional relationship between corruption experience and GDP per-capita growth. ${ }^{4}$ The experience index comes from the World Business Environment Survey (WBES) conducted by the World Bank (CORRUPT_EXP).CORRUPT_EXP measures the frequency of corruption experience, i.e. how common it is for firms to make unofficial additional payments to public officials. ${ }^{5}$ For simplicity, all corruption measures used in this paper have been rescaled such that a higher number implies more corruption. As the figure shows, the relationship between corruption and growth isn't all that clear from these graphs. Over a five

\footnotetext{
${ }^{4}$ GDP per-capita data is in 2005 PPP adjusted international dollars and comes from the World Bank.

${ }^{5}$ In a survey of the literature, Treisman (2007) emphasizes the importance of experience indices in research and uses the World Business Environment Survey, CORRUPT_EXP, index as an example. The construction of this index will be discussed in further detail in the data section of this paper.
} 
year period, CORRUPT_EXP is slightly negatively related to economic growth with the effect turning positive over an eleven year period. In addition, in both cases, the simple unconditional relationship is statistically insignificant.

The WBES also asks firms to rate on a scale of 1 (always) to 6 (never) if when making these unofficial payments, how often the service is delivered as agreed. ${ }^{6}$ As mentioned above, the response to this question is interacted with the response from the frequency of experience question. With an initial look at the data, this measure seems important for growth. First consider the countries of Brazil and the Czech Republic. These countries are classified by the World Bank as an upper-middle income economy and a high income OECD economy, respectively. Both countries received very similar scores in the frequency of corruption experience ( 2.57 and 2.58 respectively); however, Brazil experiences $77 \%$ more corruption uncertainty than the Czech Republic. In addition, the growth rate of GDP per capita from 2000-2005 in the Czech Republic is almost three times that of Brazil. A similar result occurs when comparing the two most corrupt countries according to this frequency of experience measure, Bangladesh followed by Madagascar. Bangladesh experiences more corruption than Madagascar, however, Bangladesh also experiences far less uncertainty. Consequently, the growth rate of GDP per-capita from 2000 - 2005 in Bangladesh is $3.7 \%$, while the growth rate over the same period in Madagascar is $-0.74 \%$. As Figure 2.2 shows, in general there is a strong negative relationship between this interaction term and economic growth. ${ }^{7}$ In both panels, the relationship is statistically different from zero.

\footnotetext{
${ }^{6}$ Given the conditional nature of this question, I exclude firms that responded to the former as experiencing no corruption and consequently left the uncertainty question blank as a robustness check. As a further robustness check, I exclude all firms that only responded to one of the questions. Both robustness checks are available in table 2.A2 of Chapter 2, Appendix A. However, the main results use all available information as this gives the reader a better overall measure of corruption and uncertainty using a broader sample of firms.

${ }^{7}$ Alternatively, one could interpret Figure 2 as showing that as corruption experience increases, economic growth will decrease, holding the level of uncertainty constant.
} 
Figure 2.2: Effect of interaction between frequency of corruption experience and corruption uncertainty on average GDP per-capita growth rate for 2000-2005 and 2000-2011 periods.
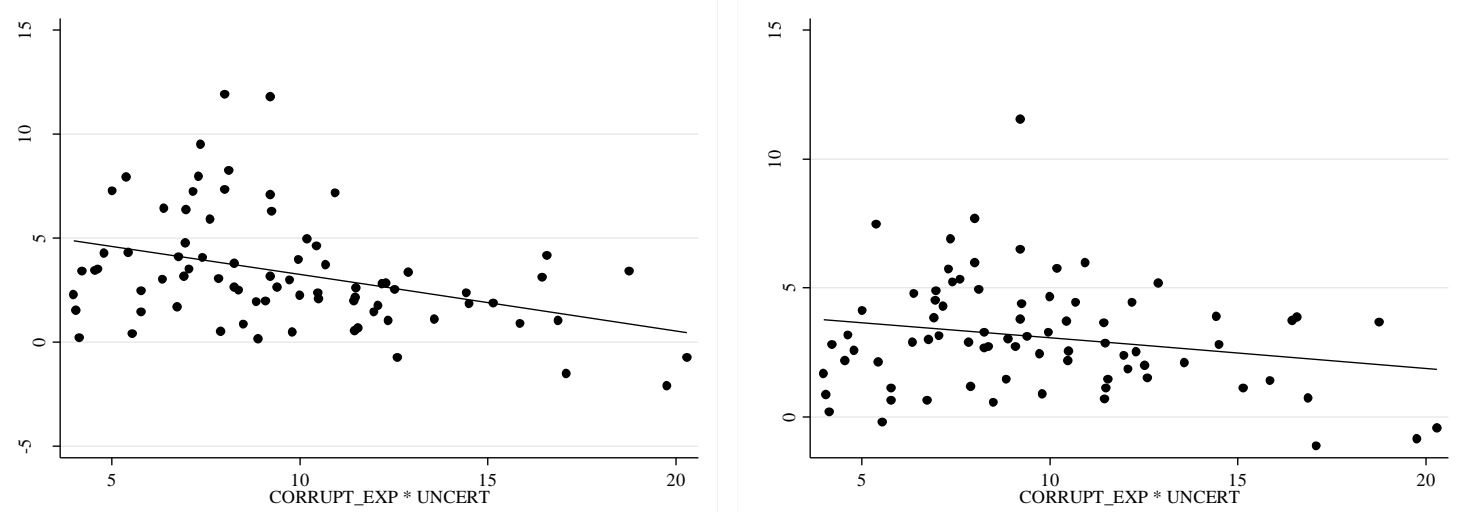

Source: Transparency International (CORRUPT_PER_1), World Bank Governance Indicators (CORRUPT_PER_2), World Business Environment Survey by the World Bank (CORRUPT_EXP), and World Bank Development Indicators $($ GROWTH).

As a preview of the results, this paper finds that over a five year period, the marginal effect of an increase in the frequency of corruption experience has a statistically significant and positive relationship with economic growth at extremely low levels of uncertainty. However, the sign of this effect becomes negative for over $60 \%$ of the sample and statistically significant and negative for $45 \%$ of the sample. Over an eleven-year period, however, more uncertainty is tolerated and the positive and statistically significant effect of corruption is relevant for $27 \%$ of the sample. The sign of this effect becomes negative for over $58 \%$ of the sample and statistically significant and negative for $45 \%$ of the sample. Furthermore, in both periods, the negative effect of corruption becomes larger with more uncertainty. Thus overall, this paper finds that corruption has a negative impact on growth, unless there is a minimal amount of uncertainty.

The empirical framework is described in 2; section 3 presents the data; section 4 summarizes the results; section 5 concludes.

\subsection{Empirical Framework}

This paper will adopt the neoclassical growth framework with a Cobb-Douglas production function (see, e.g., Barro, 1991; Barro and Sala-i-Martin, 1992; Barro et al., 1995) using cross- 
country data and will follow the interaction term framework employed in Heckelman and Wilson (2013). As shown in this literature, the path of the log of per-capita output is given by:

(2.2.1) $y_{i}(t)=\left(1-\mathrm{e}^{\beta t}\right) y_{i}{ }^{*}+\mathrm{e}^{\beta t} y_{i}(0)$,

where $i$ represents each country as the unit of observation and will be dropped in subsequent equations for simplicity, $y(t)$ represents the log of per capita output at time $t, y^{*}$ represents the steady state level of log per capita output, $y(0)$ represents the initial level of log per capita output, and $\beta$ represents the rate of convergence. Thus, $\beta$ is the rate of convergence since if $\beta<0$ then $y(t)$ approaches $y^{*}$ as $t$ approaches infinity. However, if $\beta=0$ then $y(t)=y(0)$ for all $\mathrm{t}$ and there will be no growth. Therefore, this paper will assume $\beta<0$.

The growth rate of per capita output can be found by rewriting (1) as: (2.2.2) $y(\mathrm{~T})-y(0)=\left(1-\mathrm{e}^{\beta \dagger}\right) y^{*}+\left(\mathrm{e}^{\beta t}-1\right) y(0)$, where $\mathrm{T}$ is the number of years over which growth will be examined. As in Heckelman and Wilson (2013), it is assumed that $y^{*}$ varies over time with a constant growth rate and that the variability is determined by a variety of different factors. The interest of this paper is in determining the impact that corruption and uncertainty have on economic growth, through their effect on $y^{*}$.

Therefore, this paper assumes $y^{*}=f(C R)$ is a function of corruption regimes. Specifically, (2.2.3) $f(C R)=\lambda_{0}+\lambda_{1} C O R R U P T \_E X P+\lambda_{2} U N C E R T+\lambda_{3} C O R R U P T \_E X P \times U N C E R T$, where CORRUPT_EXP is an index of corruption experience and UNCERT is an index of uncertainty. The inclusion of CORRUPT_EXP and UNCERT simply suggest that corruption experience and corruption uncertainty have their own separate impacts on growth. The inclusion of CORRUPT_EXP $\times U N C E R T$ in the model reflects the central hypothesis that the impact corruption has on growth is contingent upon the level of uncertainty involved. Taking these three 
variables together, equation (2.2.3) proxies for the type of corruption regime that exists in each country. Substituting equation (2.2.3) into equation (2.2.2) results in the following growth specification:

$(2.2 .4) g_{\mathrm{T}}=\alpha_{0}+\alpha_{1} C O R R U P T \_E X P+\alpha_{2} U N C E R T+\alpha_{3} C O R R U P T \_E X P \times U N C E R T+\theta y(0)$, where $g_{\mathrm{T}}=y(\mathrm{~T})-y(0), \alpha_{\mathrm{j}}=\lambda_{j}\left(1-\mathrm{e}^{\beta t}\right)$ and $\theta=\left(1-\mathrm{e}^{\beta t}\right)$. Differentiating with respect to CORRUPT_EXP, the model implies that the marginal impact of corruption experience on growth is: $\frac{\delta g_{\mathrm{T}}}{\delta C O R R U P T_{\_} E X P}=\alpha_{1}+\alpha_{3} U N C E R T$

This equation says that in the absence of any uncertainty, the effect of corruption on growth would be simply $\alpha_{1}$. As some researchers argue, corruption may actually "grease the wheels" of economic growth when there is a poor institutional environment (Leff, 1964; Huntington, 1968). In this case corruption in an environment with absolutely no uncertainty, may actually have a positive impact on economic growth. However, as argued in Shleifer and Vishny (1993) corruption in general is likely to come with a significant amount of uncertainty, and this uncertainty is determined by the type of regime corruption takes place in. In addition, corruption is susceptible to detrimental rent-seeking behavior, inducing uncertainty. In this regard, any positive effect that corruption may have is likely quickly offset by the negative effect of uncertainty. Given this, even if corruption "greases the wheels", i.e. if $\alpha_{1}>0, \alpha_{3}$ will likely be less than 0 , effectively offsetting this positive effect. ${ }^{8}$ Thus, in general, this paper expects that $\frac{\delta g_{\mathrm{T}}}{\delta C O R R U P T_{-} E X P}<0$.

Differentiating (4) with respect to UNCERT yields the marginal impact of uncertainty,

\footnotetext{
${ }^{8}$ The grease the wheels hypothesis will be tested in the robustness section of the paper.
} 


$$
\frac{\delta g_{T}}{\delta U N C E R T}=\alpha_{2}+\alpha_{3} \text { CORRUPT_EXP. }
$$

Like above, this paper expects that $\alpha_{3}<0$, as an increase in uncertainty in corrupt environments will likely harm growth outcomes. However, unlike corruption experiences, there is no clear hypothesis of how corruption uncertainty would affect economic growth in the absence of any corruption, and thus no clear hypothesis of what the sign of $\alpha_{2}$ will be. A low degree of corruption and a high degree of uncertainty may be the case in highly developed countries with high quality institutions. In these areas, it could be the case that this high amount of uncertainty actually deters corruption. Thus, $\alpha_{2}>0$ could signify that a high amount of uncertainty is actually keeping corruption experience at an extremely low level and improving growth outcomes. However, it could also be the case that this high level of corruption uncertainty is indicative of a country with low quality institutions and poorly defined and enforced property rights, causing it to have a negative effect, or $\alpha_{2}<0$.

\subsection{Data}

The corruption data for this paper comes from two different sources: the World Bank and Transparency International. ${ }^{9}$ Brief descriptions and sources can be found in table 2.1, while summary statistics are listed in table 2.2. The World Bank's WBES, conducted in 1999-2000, surveyed over 10,000 firms in 80 countries on both their experiences and perceptions of corruption, among other things. ${ }^{10}$ The WBES asked those conducting the interviews to read each firm the following sentence: "It is common for firms in my line of business to pay some irregular

\footnotetext{
${ }^{9}$ List of countries included in Chapter 2, Appendix A.

${ }^{10}$ There are two additional surveys that could be used; however neither includes questions of uncertainty. United Nation's Inter-Regional Crime Victims Survey measures household corruption experience, however, only includes a small number of countries each survey (e.g. the survey in 2000 only included 14 countries (Mocan, 2008)). In addition, the Global Corruption Barometer conducted by TI measures both corruption experiences and perceptions, however this is far less used in the literature. Results using these measures are therefore not reported, but available upon request.
} 


\begin{tabular}{|c|c|c|}
\hline Name & Description & Source \\
\hline \multicolumn{3}{|l|}{ Dependent Variable } \\
\hline GROWTH & Average GDP per-capita growth rate $\left(\left(\ln y_{\mathrm{T}}-\ln \mathrm{y}_{0}\right) / \mathrm{T}\right) * 100$. & $\mathrm{WB}^{1}$ \\
\hline \multicolumn{3}{|c|}{ Corruption Measures } \\
\hline CORRUPT_EXP & Common to make unofficial payments; scale 1 (least) -6 (most) corruption. & $\mathrm{WB}^{1}$ \\
\hline UNCERT & Service delivered as agreed; scale 1 (least) -6 (most) corruption. & $\mathrm{WB}^{1}$ \\
\hline CORRUPT_PER_l & Perception of corruption; scale 0 (least) -10 (most) corruption. & $\mathrm{TI}^{2}$ \\
\hline CORRUPT_PER_2 & Perception of corruption; scale -2.5 (least) -2.5 (most) corruption. & $\mathrm{WB}^{1}$ \\
\hline \multicolumn{3}{|l|}{ Other Controls } \\
\hline SHADOW & Size of the shadow economy expressed as a percent of GDP in 2000. & $\mathrm{SBM}^{3}$ \\
\hline$E D U \_P R I M A R Y$ & Avg. years in primary school of pop. 15 years and older in 2000 . & $\mathrm{BL}^{5}$ \\
\hline POP_GROWTH & Avg. population growth rate $\left(\left(\ln\right.\right.$ pop $\left.\left._{\mathrm{T}}-\ln \mathrm{pop}_{0}\right) / \mathrm{T}\right) * 100$. & $\mathrm{WB}^{1}$ \\
\hline INVEST & Avg. gross capital formation as percent of GDP from 2001- T (inclusive). & $\mathrm{WB}^{1}$ \\
\hline OPEN & Avg. of exports plus imports divided by GDP from 2001-T (inclusive). & $\mathrm{WB}^{1}$ \\
\hline DEMOCRACY & Index on a scale of 0 (autocracy) to 10 (democracy) in 2000. & Polity IV \\
\hline FREEDOM & Index of economic freedom in 2000; scale 0 (least) -10 (most) freedom. & $\mathrm{GLH}^{6}$ \\
\hline$G D P \_P C$ & Initial level of GDP per-capita in 2005 PPP adjusted dollars. & $\mathrm{WB}^{1}$ \\
\hline COMMON_LAW & Legal origin representing common law. & $\mathrm{LLSV}^{7}$ \\
\hline SOCIALIST & Legal origin representing socialist law. & $\mathrm{LLSV}^{7}$ \\
\hline Regional Dummy & $\begin{array}{l}\text { Sub-saharan Africa; North America; Middle East and North Africa; Europe } \\
\& \text { Central Asia (excluding Eastern Europe); Latin America; Eastern } \\
\text { Europe. }\end{array}$ & $\mathrm{UN}^{4}$ \\
\hline \multicolumn{3}{|l|}{ Instruments } \\
\hline LATITUDE & Absolute value of latitude. & $\operatorname{LLSV}^{7}$ \\
\hline$G_{-} G D P$ & Government consumption as percent of GDP in 1999. & $\mathrm{WB}^{1}$ \\
\hline
\end{tabular}

"additional" payment to get things done."11 The firms were then asked if this was true always, usually, frequently, sometimes, seldom, or never. The firms' responses were coded on a scale from 1 (always true) to 6 (never true), and therefore, have been rescaled so that a higher number means the statement is more likely to be true $\left(C O R R U P T_{-} E X P\right) .{ }^{12}$ This measure has been used in the literature as a measure of corruption experience since it is assumed that firms will answer based on their own experience (e.g., Treisman (2007) and Aidt (2009)).

\footnotetext{
${ }^{11}$ A majority of the interviews were done face-to-face, reducing the possibility of a response bias (Batra et al., 2003). However, countries in Africa responded via mail and consequently had low response rates. Therefore, in the table A1.2 of Chapter 2, Appendix A I re-estimate the main specifications after excluding countries in Africa finding no change in the results.

${ }^{12}$ This rescaling is done to make the interpretation of the results more intuitive. A higher value of both CORRUPT_EXP and the uncertainty measure imply higher levels of corruption and uncertainty, respectively.
} 


\begin{tabular}{lcccc}
\hline \multicolumn{2}{l}{ Table 2.2: Summary Statistics. } & \multicolumn{3}{c}{$\mathbf{2 0 0 0 - 2 0 1 1}$} \\
Name & Mean & Std. Dev. & Mean & Std. Dev. \\
& & & & \\
& 2.691 & 3.16 & 2.501 & 2.404 \\
GROWTH & & & & \\
& 2.857 & 0.851 & 2.857 & 0.851 \\
CORRUPT_EXP & 3.393 & 0.813 & 3.393 & 0.813 \\
UNCERT & 5.241 & 2.388 & 5.241 & 2.388 \\
CORRUPT_PER_1 & 0.018 & 1.005 & 0.018 & 1.005 \\
CORRUPT_PER_2 & & & & \\
& 37.264 & 13.540 & 8.7 & 67.3 \\
SHADOW & 4.545 & 1.521 & 4.545 & 1.521 \\
EDU_PRIMARY & 1.496 & 1.344 & 1.482 & 1.474 \\
POP_GROWTH & 22.623 & 7.401 & 23.501 & 7.13 \\
INVEST & 90.03 & 48.246 & 93.781 & 50.036 \\
OPEN & 4.902 & 3.983 & 4.902 & 3.983 \\
DEMOCRACY & 6.566 & 1.069 & 6.566 & 1.069 \\
FREEDOM & 10773 & 12902 & 10773 & 12902 \\
GDP_PC & 0.341 & 0.475 & 0.341 & 0.475 \\
COMMON_LAW & 0.291 & 0.457 & 0.291 & 0.457 \\
SOCIALIST & & & & \\
Regional Dummy & & & & \\
Instruments & 24.856 & 16.681 & 24.856 & 16.681 \\
LATITUDE & 16.338 & 7.174 & 16.338 & 7.174 \\
G_GDP & & & & \\
\hline
\end{tabular}

In addition to the questions pertaining to experience, the WBES also asks questions regarding the uncertainty and predictability surrounding corrupt activities. This paper uses one of these questions regarding the certainty of the delivery of services that required additional payments, or bribes (UNCERT). The survey specifically asks firms to respond to the following sentence on a scale of 1 (always) to 6 (never): "If a firm pays the required "additional payments" the service is usually also delivered as agreed." Interestingly, CORRUPT_EXP and UNCERT have a very low correlation coefficient (0.010). This is reinforcing the idea that it is the regimes in which corruption takes place that determines uncertainty, not the institutional environment or level of corruption. Therefore, interacting UNCERT with the corruption experience measure will give some indication of whether the beneficial or detrimental effects of corruption depend on the type of corruption regime $\left(C O R R U P T \_E X P \times U N C E R T\right)$. As described 
in the previous section, if the interaction is negative, this means that the effect corruption has on growth worsens as uncertainty increases.

In addition to including a measure of corruption experience, this paper will include a measure of corruption perceptions as an additional control. The previous empirical literature relies on either corruption perception indices or corruption experience indices when estimating the effect of corruption on economic growth. The two perception indices considered in this paper are Transparency International's Corruption Perception Index (CORRUPT_PER_1) and the World Bank's Control of Corruption Index (CORRUPT_PER_2).CORRUPT_PER_l is comprised of data from 16 surveys from 8 different sources and measures the degree to which corruption is perceived to exist among public officials and politicians. Both perceptions indices are composite survey based measures. CORRUPT_PER_2 is comprised of data from 31 different sources and is based on the perceptions of the extent of corruption, i.e. to which public power is exercised for private gain (Kaufmann et al. (2010)).

The perception indices rely on the views of survey respondents or expert evaluations of the extent of corruption in a country, rather than focusing on respondents' own experience with corruption. Although both experience and perception indices are intended to measure the actual extent of corruption in a country, there may be important differences between the two. For example, as noted in Donchev and Ujhelyi (2014), an individual may actually be basing their perceptions of corruption on factors other than their experience, such as events publicized in the media. Thus, we may expect that perception indices are more likely to be biased by the current institutional environment or performance of the economy than experience indices. More formally, Donchev and Ujhelyi (2014) show that the WBES indices are not statistically significant predictors of perceived corruption, using CORRUPT_PER_l as a measure of 
perception, once other factors, such as the level of per-capita GDP, are controlled for. ${ }^{13}$ This is suggesting that these two measures may be picking up different factors.

Furthermore, these differences may be important for economic growth and the use of these two different measures has led to mixed results. While there are a few exceptions, in general, the finding that corruption perceptions negatively impact economic growth, while corruption experience has no relationship with growth is common. ${ }^{14}$ For example, Aidt (2009) finds a significant negative relationship between perceived corruption and the growth rate of GDP per capita. However, he finds that this relationship becomes insignificant when using a corruption experience index in place of the corruption perceptions index.

Therefore, to the extent that corruption perceptions are not representative of corruption experiences, we can see that these corruption perceptions and corruption experience may have their own separate impact on economic growth. Thus, in addition to the experience measures, this paper will also include the CORRUPT_PER_l measure, available every year starting in 1995, and the CORRUPT_PER_2 measure, available every other year from 1996-2002 on an annual basis thereafter. ${ }^{15}$ In order for these measures to match the timing of the experience measures the values of each index in the year 2000 are used. For simplicity, as with the

\footnotetext{
${ }^{13}$ In addition, several other researchers have noted that corruption experience is only weakly related to corruption perceptions (Mocan (2004; 2009), Gonzales et al. (2007), Weber Abramo (2008), Olken (2009), Razafindrakoto and Roubaud (2010)).

${ }^{14}$ Mauro (1995), Mo (2001), Li, Xu, and Zou (2001), Abed and Davoodi (2002), and Méon and Sekkat (2005) are all studies that have found corruption perceptions to be negatively correlated with economic growth. While the literature using corruption experience measures is far less dense, Mocan $(2004 ; 2009)$ and Aidt (2009) find that corruption experience has no relationship to economic growth.

${ }^{15}$ There is an additional corruption perception index available for purchase from International Country Risk Guide; however, previous literature sites the correlation between this index and the perception indices used in this paper, CORRUPT_PER_l and CORRUPT_PER_2, at above .87 (see e.g., Donchev and Ujhelyi (2014)), therefore they are likely going to produce similar results.
} 
experience indices, perception indices have been rescaled such that a higher number implies more corruption. ${ }^{16}$

The cases where only initial level of GDP per-capita and the corruption measures are controlled for are referred to as the baseline specifications. In addition to the corruption measures, other factors that are commonly thought to also influence economic growth in the literature are also included as controls. This group of variables is referred to as basic controls.

Following Méon and Sekkat (2005) and Aidt (2009), this paper controls for initial level of primary education (EDU_PRIMARY) and average investment share of GDP (INVEST), as well as the initial level of democracy and economic freedom (DEMOCRACY; FREEDOM) as in Heckelman and Powell (2010). In addition to initial levels, average trade openness (OPEN) and average population growth $\left(P O P \_G R O W T H\right)$ during the growth period are included as controls as in Méon and Sekkat (2005) and Aidt (2009), respectively. Averages are included for some variables, rather than initial levels, simply because these variables are extremely volatile over time. For example, INVEST has varied by as much as 34\% since 1960 for Colombia, a country included in this study.

Given that corruption is often thought to impact the size of the shadow economy (Dreher and Schneider, 2010), and the shadow economy is often thought to be related to economic growth (La Porta and Shleifer, 2008) it is also important to control for the size of the informal economy (Bologna, 2015a). The only measure of the shadow economy available across a wide range of countries is derived using a Multiple Indicators Multiple Causes (MIMIC) model (Schneider et al., 2010). Specifically, since the shadow economy is not directly observable across

\footnotetext{
${ }^{16}$ In a survey of the literature, Treisman (2007) refers to the CORRUPT_PER_1 and CORRUPT_PER_2 indices as the most commonly used in empirical work. In addition, he emphasizes the importance of experience indices in future research and uses the World Business Environment Survey, APAY, index as an example.
} 
countries, Schneider et al. (2010) treat the size of the shadow economy as a latent variable and uses several measurable causal or indicator variables to measure it. For example, they assume that the size of the shadow economy is determined by tax burdens, regulatory burdens, and overall institutional quality, among many other factors. They use measurements of each of these causal variables to estimate the size of the shadow economy as a percentage of "official" GDP $(S H A D O W)$. Thus, although it is important to control for the size of the unofficial, or shadow, economy, it would be not be surprising if this variable has little effect given that many of the casual variables determining its size are included as explanatory variables in my model.

Lastly, following La Porta et al. (1999), I include two dummy variables indicating whether or not a country is of common law legal origin or of a socialist law origin, as legal origins have been shown to be important to economic growth (COMMON_LAW;SOCIALIST). ${ }^{17}$ The basic controls are then supplemented with a robustness analysis using additional controls and instrumental variables. The robustness checks will be explained in detail in the next section. See Table 2.1 and Table 2.2 for names, a brief description, and sources of the data.

\section{$2.4 \quad$ Results}

The regressions are estimated using ordinary least squares and cross-sectional data for a maximum of 78 countries. (The number of countries depends on the controls used.) As the corruption experience data is only available for the year 2000, this paper estimates the relationship between corruption and GDP per-capita growth over the subsequent five- and eleven-year periods. As argued in Aidt (2009), and to some extent in Shleifer and Vishny (1993), even if corruption has a positive impact on growth in the short term this effect will dissipate over

\footnotetext{
${ }^{17}$ La Porta et al. (1999) also focus on three variations of civil law: French, Scandinavian, and German. To avoid collinearity issues, civil law in general is excluded from the analysis.
} 
the longer term as corruption often leads to an inefficient allocation of resources. Thus, it is important to try to estimate the effects of corruption over two time periods.

The specification is based on equation (2.2.4), defining $g_{\mathrm{T}}$ as the average growth rate per year (i.e. $\left.g_{\mathrm{T}}=\frac{y(\mathrm{~T})-y(0)}{\mathrm{T}}\right)$ and adding in EDU_PRIMARY,POP_GROWTH, INVEST, OPEN, DEMOCRACY, FREEDOM, SHADOW, COMMON_LAW, and SOCIALIST as controls. The focus of the results is on the experience measure CORRUPT_EXP as it is the most commonly used experience measure and is available for a total of 80 countries. Table $\mathbf{2 . 3}$ compares the effect of CORRUPT_EXP and CORRUPT_EXP $\times$ UNCERT with the corruption perceptions indices, CORRUPT_PER_1 and CORRUPT_PER_2, on economic growth without including any additional controls. In both periods, CORRUPT_PER_1 and CORRUPT_PER_2 are positive and statistically significant, while CORRUPT_EXP, and its interaction, are only statistically significant in the 2000-2011 specification. Importantly, in the 2000-2011 period the interaction between experience and uncertainty, CORRUPT_EXP $\times U N C E R T$, is negative and statistically significant as expected.

As indicated in the previous literature, the perceptions of corruption may be picking up other qualities of the country that aren't necessarily related to actual corruption. Furthermore, these other qualities may be directly related to growth and may be driving the relationship between corruption perceptions and economic growth. For example, Mocan (2009) finds that corruption perceptions are negatively related to long-run economic growth; however, once controlling for institutional quality this effect disappears. Similarly, Mo (2001) finds the negative effect of corruption perceptions to be insignificant once education is controlled for. 


\begin{tabular}{|c|c|c|c|c|c|c|}
\hline & & $2000-2005$ & & & $2000-2011$ & \\
\hline & (1) & (2) & (3) & (4) & (5) & (6) \\
\hline CORRUPT_PER_l & $\begin{array}{l}0.362^{*} \\
(0.197)\end{array}$ & & & $\begin{array}{l}0.225^{*} \\
(0.133)\end{array}$ & & \\
\hline CORRUPT_PER_2 & & $\begin{array}{c}0.981 * * * \\
(0.358)\end{array}$ & & & $\begin{array}{c}0.630^{* *} \\
(0.260)\end{array}$ & \\
\hline CORRUPT_EXP & $\begin{array}{c}1.168 \\
(1.562)\end{array}$ & $\begin{array}{c}0.707 \\
(1.089)\end{array}$ & $\begin{array}{c}0.920 \\
(1.178)\end{array}$ & $\begin{array}{c}2.754 * * \\
(1.151)\end{array}$ & $\begin{array}{l}1.983^{* * *} \\
(0.785)\end{array}$ & $\begin{array}{c}2.103 * * \\
(0.851)\end{array}$ \\
\hline UNCERT & $\begin{array}{c}0.245 \\
(1.260)\end{array}$ & $\begin{array}{c}0.069 \\
(1.038)\end{array}$ & $\begin{array}{c}0.009 \\
(1.086)\end{array}$ & $\begin{array}{c}2.004 * * \\
(0.900)\end{array}$ & $\begin{array}{l}1.577 * * \\
(0.684)\end{array}$ & $\begin{array}{l}1.522 * * \\
(0.714)\end{array}$ \\
\hline CORRUPT_EXP×UNCERT & $\begin{array}{l}-0.663 \\
(0.445)\end{array}$ & $\begin{array}{c}-0.576^{*} \\
(0.320)\end{array}$ & $\begin{array}{l}-0.550 \\
(0.338)\end{array}$ & $\begin{array}{c}-1.024 * * * \\
(0.336)\end{array}$ & $\begin{array}{c}-0.824 * * * \\
(0.235)\end{array}$ & $\begin{array}{c}-0.807 * * * \\
(0.246)\end{array}$ \\
\hline$G D P \_P C$ & $\begin{array}{l}-0.510 \\
(0.450) \\
\end{array}$ & $\begin{array}{l}-0.219 \\
(0.424) \\
\end{array}$ & $\begin{array}{l}-0.698 \\
(0.422) \\
\end{array}$ & $\begin{array}{c}-0.725^{* *} * \\
(0.317) \\
\end{array}$ & $\begin{array}{l}-0.428 \\
(0.313) \\
\end{array}$ & $\begin{array}{c}-0.751 * * * \\
(0.275)\end{array}$ \\
\hline $\begin{array}{l}\text { Obs. } \\
\mathrm{R}^{2}\end{array}$ & $\begin{array}{c}52 \\
0.412\end{array}$ & $\begin{array}{c}63 \\
0.411\end{array}$ & $\begin{array}{c}63 \\
0.342 \\
\end{array}$ & $\begin{array}{c}51 \\
0.412\end{array}$ & $\begin{array}{c}62 \\
0.364\end{array}$ & $\begin{array}{c}62 \\
0.312\end{array}$ \\
\hline
\end{tabular}

Therefore, the above relationships are re-estimated with the basic set of controls as described in the previous section. As can be seen in Table 2.4 the coefficients on corruption perceptions become insignificant in every specification once these other factors are controlled for. Thus this is suggesting that corruption perceptions do not influence growth rates on their own. In addition, CORRUPT_EXP and CORRUPT_EXP $\times$ UNCERT now become statistically significant in every specification. Furthermore, the signs of CORRUPT_EXP and CORRUPT_EXP $\times U N C E R T$ are as expected.

In order to interpret the marginal effect of corruption experience, as in equation (2.2.5), we take a closer look at the estimates presented in columns (3) and (6) of table 2.4. These conditional marginal effects are summarized in table 2.5 for the both five-year period and eleven-year period. In addition, these tables are summarized visually in figure 2.3. These tables tell us the marginal effects, and statistical significance, of corruption experience at specified values of uncertainty. 
Table 2.4: Effect of perceptions (CORRUPT_PER_1; CORRUPT_PER_2) versus frequency of corruption experience $\left(C O R R U P T \_E X P\right)$ on average GDP per-capita growth; basic controls included.

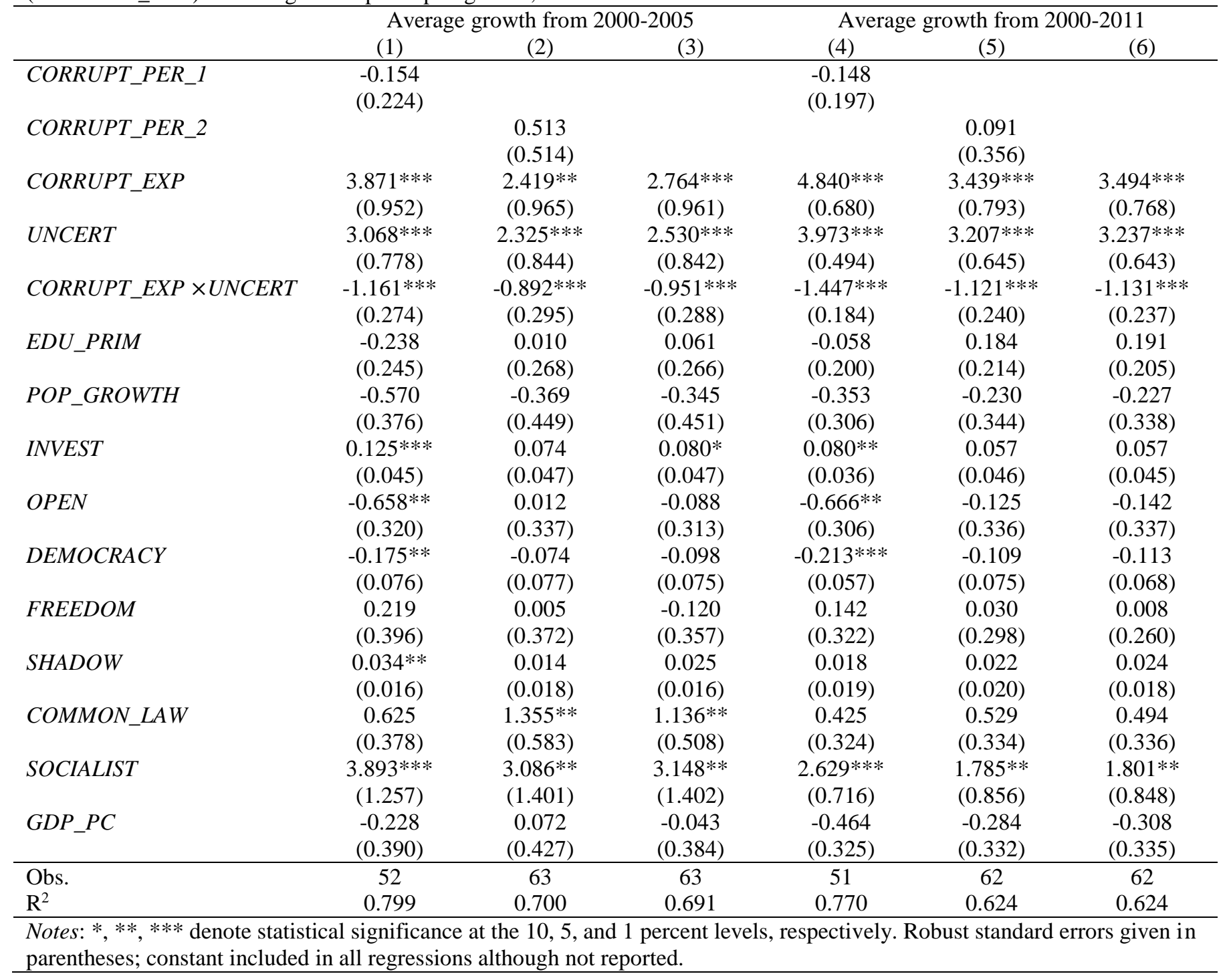

Table 2.5: Conditional marginal effect of both corruption experience (CORRUPT_EXP) on growth.

\begin{tabular}{|c|c|c|c|c|c|c|}
\hline \multirow[b]{2}{*}{ UNCERT Value Meaning } & \multicolumn{3}{|c|}{ Average growth from 2000-2005 } & \multicolumn{3}{|c|}{ Average growth from 2000-2011 } \\
\hline & $\begin{array}{c}\text { UNCERT } \\
\text { Value }\end{array}$ & $d y / d x$ & $p$-value & $\begin{array}{c}\text { UNCERT } \\
\text { Value }\end{array}$ & $d y / d x$ & $p$-value \\
\hline Potential Minimum & 1.000 & 1.812 & 0.013 & 1.000 & 2.363 & 0.000 \\
\hline Sample Minimum & 2.048 & 0.815 & 0.093 & 2.048 & 1.178 & 0.002 \\
\hline Sample Median & 3.421 & -0.490 & 0.209 & 3.421 & -0.374 & 0.194 \\
\hline Sample Maximum & 4.921 & -1.918 & 0.005 & 4.921 & -2.071 & 0.000 \\
\hline Potential Maximum & 6.000 & -2.945 & 0.002 & 6.000 & -3.292 & 0.000 \\
\hline Statistically Significant Break Point & 2.075 & 0.789 & 0.100 & 2.670 & 0.475 & 0.100 \\
\hline Statistically Significant Break Point & 3.617 & -0.678 & 0.100 & 3.523 & -0.490 & 0.100 \\
\hline Positive to Negative Turning Point & 2.905 & 0.000 & 1.000 & 3.090 & 0.000 & 1.000 \\
\hline
\end{tabular}


Figure 2.3: Estimated marginal impacts of corruption experience (CORRUPT_EXP) on growth, conditional on the level of uncertainty (UNCERT) for the 2000-2005 period (panel a) and the 20002011 period (panel $b$ ).
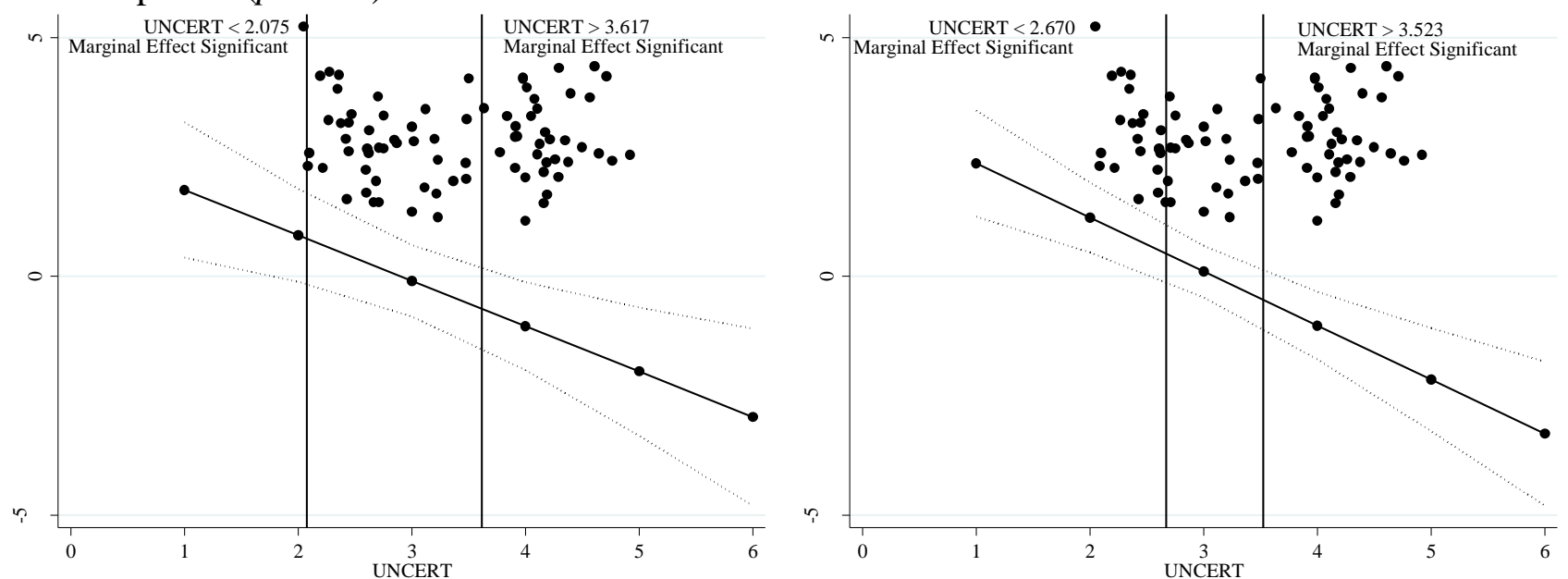

Notes: Panel a summarizes results presented in column (3) of table 2.4. Panel $b$ summarizes the results presented in column (6) of table 2.4.

Starting with the five-year period, in table 2.5, we see that at very low levels of UNCERT, the marginal effect of corruption on growth is actually positive and statistically significant. However, only two percent of the countries in the sample have values of uncertainty that are lower than the 2.075 cut off. Furthermore, the marginal effect becomes negative for any level of uncertainty above 2.905 , which amounts to over 62 percent of the sample, and statistically significant and negative for 45 percent of the sample. Thus, in only very extreme cases of minimal uncertainty we see corruption having a positive relationship to growth. In a majority of the sample we see that corruption is detrimental to growth.

In the eleven-year period, however, we see that corruption is slightly more tolerated. In countries with uncertainty levels below 2.670 (27 percent of the sample), corruption can have a positive impact. As before, however, this effect becomes negative fairly quickly for uncertainty levels above 3.090 (58 percent of the sample) and negative and statistically significant for more than 45 percent of the sample. Thus, although it seems that corruption is more tolerated at low 
levels on uncertainty in the longer run, there is a still a strong negative relationship at high levels of uncertainty.

In addition, all effects seem to become economically large at extreme values. For example, using the 2000-2005 sample maximum estimates provided in table $\mathbf{2 . 5}$, a one unit increase in CORRUPT_EXP(equivalent to moving from Sweden to the United States), when uncertainty is at its highest, is associated with a decrease in GROWTH by 2.945 percentage points, which is greater than the entire mean of GROWTH for the overall sample. Thus, in countries that experience the most uncertainty, corruption will likely have a strong negative impact. Over the eleven-year period we see that these effects are even larger at extreme values of corruption and uncertainty.

Some researchers argue that the effect corruption has on economic growth depends on the quality of the institutional environment and may actually be positive in a second best world (Leff, 1964; Huntington, 1968). For example, Leff (1964) refers to corruption as a 'safeguard' against the losses of 'bad policies'; i.e., in an environment with ill-functioning institutions corruption may be beneficial in that it helps entrepreneurs to circumvent tedious, time consuming regulations. Lui (1985) develops a model showing that corruption decreases the average time spent in a queue, thus speeding up slow bureaucratic processes. However, firm level empirical evidence suggests the opposite: higher levels of corruption result in more wasted time and higher costs (Kauffman and Wei, 1999) as well as lower firm growth in general (Fisman and Svennson, 2007). ${ }^{18}$

\footnotetext{
${ }^{18}$ It is possible to classify corruption into two broad types, cost-reducing and cost-increasing (Sequeira and Djankov, 2010). Corruption that is cost-reducing allows individuals and officials to collude to get around illfunctioning institutions. Corruption that is cost-increasing involves bribery payments that are not mutually beneficial; they only raise the cost for individuals and firms. However, since corruption measures do not distinguish between the types of corruption, it is impossible to focus on one or another in an empirical study. Instead, researchers look at how the effect of corruption differs based on the overall institutional environment (e.g. Bologna,
} 
More relevant to this paper, however, are the two macroeconomic studies that attempt to test the grease the wheels argument by interacting measures of corruption and institutional quality. Interestingly, these two studies find the results are sensitive to whether we focus on economic or political institutions. Heckelman and Powell (2010) find evidence that corruption is beneficial when a measure of economic freedom is low; however, Méon and Sekkat (2005) find that the effects of corruption tend to worsen in lower quality political institutions.

Thus, in order to compare this study with this previous corruption literature examining the "grease the wheels" hypothesis specifications table $\mathbf{2 . 6}$ present results that include an interaction term of institutional quality and corruption experience for both periods, focusing on economic institutions. This will indicate whether institutional quality or uncertainty is the fundamental determinant of whether corruption is good or bad for growth.

As can be seen in specifications (1) and (3) in table 2.6, when excluding the uncertainty measures $(U N C E R T ;$ CORRUPT_EXP $\times$ UNCERT) and including an interaction between institutional quality and corruption experience (CORRUPT_EXP $\times$ FREEDOM) instead, corruption experience is no longer statistically significant. In addition, we see that the interaction between institutional quality and experience is statistically insignificant. Furthermore, specifications (2) and (4) show that when including both CORRUPT_EXP $\times$ UNCERT and CORRUPT_EXP $\times$ FREEDOM, CORRUPT_EXP $\times$ UNCERT becomes statistically significant at the one percent level. FREEDOM and CORRUPT_EXP $\times$ FREEDOM are never statistically significant.

2015b). A common finding, though, is that corruption is more prevalent in countries with a larger regulatory state (e.g., Holcombe and Bourdeaux, 2015). 


\begin{tabular}{|c|c|c|c|c|}
\hline & \multicolumn{2}{|c|}{ Average growth from $2000-2005$} & \multicolumn{2}{|c|}{ Average growth from 2000-2011 } \\
\hline & (1) & (2) & (3) & (4) \\
\hline CORRUPT_EXP & $\begin{array}{c}1.884 \\
(1.739)\end{array}$ & $\begin{array}{c}2.990 \\
(1.940)\end{array}$ & $\begin{array}{c}0.494 \\
(1.763)\end{array}$ & $\begin{array}{c}1.661 \\
(1.577)\end{array}$ \\
\hline UNCERT & & $\begin{array}{c}2.511 * * * \\
(0.895)\end{array}$ & & $\begin{array}{c}3.437 * * * \\
(0.651)\end{array}$ \\
\hline CORRUPT_EXP $\times U N C E R T$ & & $\begin{array}{c}-0.945^{* * * *} \\
(0.303)\end{array}$ & & $\begin{array}{c}-1.200 * * * \\
(0.236)\end{array}$ \\
\hline$E D U \_P R I M$ & $\begin{array}{c}0.105 \\
(0.283)\end{array}$ & $\begin{array}{c}0.066 \\
(0.282)\end{array}$ & $\begin{array}{c}0.244 \\
(0.222)\end{array}$ & $\begin{array}{c}0.145 \\
(0.213)\end{array}$ \\
\hline POP_GROWTH & $\begin{array}{l}-0.746^{*} \\
(0.437)\end{array}$ & $\begin{array}{l}-0.342 \\
(0.457)\end{array}$ & $\begin{array}{l}-0.627^{*} \\
(0.358)\end{array}$ & $\begin{array}{l}-0.191 \\
(0.336)\end{array}$ \\
\hline INVEST & $\begin{array}{c}0.094 \\
(0.064)\end{array}$ & $\begin{array}{c}0.081 \\
(0.049)\end{array}$ & $\begin{array}{c}0.054 \\
(0.066)\end{array}$ & $\begin{array}{c}0.052 \\
(0.044)\end{array}$ \\
\hline OPEN & $\begin{array}{c}0.086 \\
(0.425)\end{array}$ & $\begin{array}{l}-0.097 \\
(0.333)\end{array}$ & $\begin{array}{c}0.214 \\
(0.473)\end{array}$ & $\begin{array}{c}-0.098 \\
(0.331)\end{array}$ \\
\hline DEMOC & $\begin{array}{l}-0.033 \\
(0.092)\end{array}$ & $\begin{array}{l}-0.097 \\
(0.076)\end{array}$ & $\begin{array}{l}-0.052 \\
(0.096)\end{array}$ & $\begin{array}{l}-0.116^{*} \\
(0.064)\end{array}$ \\
\hline FREEDOM & $\begin{array}{c}0.392 \\
(0.689)\end{array}$ & $\begin{array}{l}-0.023 \\
(0.750)\end{array}$ & $\begin{array}{l}-0.110 \\
(0.724)\end{array}$ & $\begin{array}{l}-0.793 \\
(0.577)\end{array}$ \\
\hline CORRUPT_EXP $\times F R E E$ & $\begin{array}{l}-0.285 \\
(0.256)\end{array}$ & $\begin{array}{l}-0.037 \\
(0.286)\end{array}$ & $\begin{array}{l}-0.066 \\
(0.264)\end{array}$ & $\begin{array}{c}0.308 \\
(0.230)\end{array}$ \\
\hline SHADOW & $\begin{array}{c}0.026 \\
(0.019)\end{array}$ & $\begin{array}{c}0.025 \\
(0.017)\end{array}$ & $\begin{array}{c}0.023 \\
(0.024)\end{array}$ & $\begin{array}{c}0.019 \\
(0.020)\end{array}$ \\
\hline COMMON_LAW & $\begin{array}{c}1.466 * * \\
(0.601)\end{array}$ & $\begin{array}{l}1.116^{* * *} \\
(0.547)\end{array}$ & $\begin{array}{l}0.972 * \\
(0.512)\end{array}$ & $\begin{array}{l}0.648^{*} \\
(0.356)\end{array}$ \\
\hline SOCIALIST & $\begin{array}{c}2.037 \\
(1.392)\end{array}$ & $\begin{array}{c}3.145^{* * *} \\
(1.429)\end{array}$ & $\begin{array}{c}0.338 \\
(0.858)\end{array}$ & $\begin{array}{l}1.929 * * \\
(0.861)\end{array}$ \\
\hline$G D P \_P C$ & $\begin{array}{c}0.079 \\
(0.461)\end{array}$ & $\begin{array}{l}-0.043 \\
(0.387)\end{array}$ & $\begin{array}{l}-0.211 \\
(0.431)\end{array}$ & $\begin{array}{c}-0.276 \\
(0.330) \\
\end{array}$ \\
\hline Observations & 63 & 63 & 62 & 62 \\
\hline R-squared & 0.613 & 0.691 & 0.417 & 0.634 \\
\hline
\end{tabular}

Further, if we look at table 2.7 and table 2.8 we see that the effect corruption experience has on economic growth largely depends on the level of uncertainty, not the level of economic freedom. Looking at panel $a$ in both tables, we see that at extremely high levels of uncertainty corruption has a negative impact on growth regardless of the level of freedom, and similarly has a positive impact on growth at extremely low levels of uncertainty, regardless of the level of freedom. Further, looking at panel $b$ we see that regardless of economic freedom being at its maximum or minimum, the effect of corruption experiences still worsens as uncertainty 
increases. Thus, overall, these results suggest that uncertainty regarding corruption is more important in determining the effects corruption has on growth than the institutional environment in which it exists.

Table 2.7: Conditional marginal effect of both corruption experience (CORRUPT_EXP) on growth from 20002005 , holding economic freedom and uncertainty at given values.

Panel a: Conditional marginal effect of corruption experience on growth across different values of economic freedom, holding uncertainty fixed at extreme values.

\begin{tabular}{|c|c|c|c|c|c|c|}
\hline \multirow[b]{2}{*}{ FREEDOM Value Meaning } & \multicolumn{3}{|c|}{$\begin{array}{l}\begin{array}{l}U N C E R T \text { at potential maximum } \\
(=6)\end{array}\end{array}$} & \multicolumn{3}{|c|}{$\begin{array}{c}\text { UNCERT at potential minimum } \\
(=1)\end{array}$} \\
\hline & $\begin{array}{l}\text { FREEDOM } \\
\text { Value }\end{array}$ & $d y / d x$ & $p$-value & $\begin{array}{l}\text { FREEDOM } \\
\text { Value }\end{array}$ & $d y / d x$ & $p$-value \\
\hline Potential Minimum & 0.000 & -2.679 & 0.267 & 0.000 & 2.045 & 0.288 \\
\hline Sample Minimum & 4.560 & -2.848 & 0.031 & 4.560 & 1.875 & 0.032 \\
\hline Sample Median & 6.550 & -2.922 & 0.004 & 6.550 & 1.802 & 0.016 \\
\hline Sample Maximum & 8.650 & -2.999 & 0.003 & 8.650 & 1.724 & 0.094 \\
\hline Potential Maximum & 10.000 & -3.050 & 0.010 & 10.000 & 1.673 & 0.207 \\
\hline
\end{tabular}

Panel b: Conditional marginal effect of corruption experience on growth across different values of uncertainty, holding economic freedom fixed at extreme values.

\begin{tabular}{|c|c|c|c|c|c|c|}
\hline \multirow[b]{2}{*}{ UNCERT Value Meaning } & \multicolumn{3}{|c|}{$\begin{array}{c}\text { FREEDOM at potential maximum } \\
\qquad(=10)\end{array}$} & \multicolumn{3}{|c|}{$\begin{array}{l}\text { FREEDOM at potential minimum } \\
\qquad(=0)\end{array}$} \\
\hline & $\begin{array}{l}\text { UNCERT } \\
\text { Value }\end{array}$ & $d y / d x$ & $\mathrm{p}$-value & $\begin{array}{l}\text { UNCERT } \\
\text { Value }\end{array}$ & $d y / d x$ & p-value \\
\hline Potential Minimum & 1.000 & 1.673 & 0.207 & 1.000 & 2.045 & 0.288 \\
\hline Sample Minimum & 2.048 & 0.683 & 0.543 & 2.048 & 1.055 & 0.585 \\
\hline Sample Median & 3.420 & -0.613 & 0.528 & 3.420 & -0.241 & 0.905 \\
\hline Sample Maximum & 4.921 & -2.031 & 0.046 & 4.921 & -1.659 & 0.455 \\
\hline Potential Maximum & 6.000 & -3.050 & 0.010 & 6.000 & -2.679 & 0.267 \\
\hline
\end{tabular}

As commonly pointed out in the literature, cross-country growth regressions often suffer from omitted variable bias since some factors, such as the cultural setting in each country, cannot be control for. In order to attempt to control for some of these cultural factors specifications (1) and (4) in table 2.9 include the basic controls as before, but these specifications also include regional dummy variables, as defined in the United Nations Statistics Division. As can be seen in both tables, the signs and significance of corruption experience and the interaction between corruption experience and uncertainty are largely unaffected by the inclusion of these additional variables. 
Table 2.8: Conditional marginal effect of both corruption experience (CORRUPT_EXP) on growth from 20002011, holding economic freedom and uncertainty at given values.

Panel a: Conditional marginal effect of corruption experience on growth across different values of economic freedom, holding uncertainty fixed at extreme values.

\begin{tabular}{|c|c|c|c|c|c|c|}
\hline & \multicolumn{3}{|c|}{$\begin{array}{c}\begin{array}{c}\text { UNCERT at potential maximum } \\
(=6)\end{array}\end{array}$} & \multicolumn{3}{|c|}{$\begin{array}{c}\text { UNCERT at potential minimum } \\
(=1)\end{array}$} \\
\hline & $\begin{array}{l}\text { FREEDOM } \\
\text { Value }\end{array}$ & $d y / d x$ & $p$-value & $\begin{array}{l}\text { FREEDOM } \\
\text { Value }\end{array}$ & $d y / d x$ & $p$-value \\
\hline Potential Minimum & 0.000 & -5.540 & 0.004 & 0.000 & 0.461 & 0.765 \\
\hline Sample Minimum & 4.560 & -4.135 & 0.000 & 4.560 & 1.866 & 0.007 \\
\hline Sample Median & 6.550 & -3.521 & 0.000 & 6.550 & 2.480 & 0.000 \\
\hline Sample Maximum & 8.650 & -2.874 & 0.001 & 8.650 & 3.127 & 0.000 \\
\hline Potential Maximum & 10.000 & -2.458 & 0.015 & 10.000 & 3.543 & 0.001 \\
\hline
\end{tabular}

Panel $b$ : Conditional marginal effect of corruption experience on growth across different values of uncertainty, holding freedom fixed at extreme values.

\begin{tabular}{|c|c|c|c|c|c|c|}
\hline & \multicolumn{3}{|c|}{$\begin{array}{l}\text { FREEDOM at potential maximum } \\
(=10)\end{array}$} & \multicolumn{3}{|c|}{$\begin{array}{c}\text { FREEDOM at potential minimum } \\
\qquad(=0)\end{array}$} \\
\hline & $\begin{array}{l}\text { UNCERT } \\
\text { Value }\end{array}$ & $d y / d x$ & p-value & $\begin{array}{l}\text { UNCERT } \\
\text { Value }\end{array}$ & $d y / d x$ & $\mathrm{p}$-value \\
\hline Potential Minimum & 1.000 & 3.543 & 0.001 & 1.000 & 0.461 & 0.765 \\
\hline Sample Minimum & 2.048 & 2.285 & 0.012 & 2.048 & -0.797 & 0.605 \\
\hline Sample Median & 3.420 & 0.638 & 0.426 & 3.420 & -2.443 & 0.129 \\
\hline Sample Maximum & 4.921 & -1.163 & 0.178 & 4.921 & -4.245 & 0.017 \\
\hline Potential Maximum & 6.000 & -2.458 & 0.015 & 6.000 & -5.540 & 0.004 \\
\hline
\end{tabular}

Notes: These estimates are summarizing the results presented in column (4) of table 5. Standard errors are corrected for heteroskedasticity.

The last two specifications for each period in table 2.9, specifications (2) - (3) and (5) (6), instrument for corruption experience with instruments that are common in the literature using two-staged least squares. ${ }^{19}$ Specifications (2) and (5) include the absolute value of a country's latitude and government consumption as a share of GDP as instruments for corruption experience; while specifications (3) and (6) in both tables includes only the absolute value of a country's latitude alone as in instrument for corruption experience. As discussed in Treisman (2007), finding a valid instrument that influences corruption, with no effect on growth, is nearly impossible. Thus, these last specifications are intended only as a robustness check and should be interpreted with caution.

\footnotetext{
${ }^{19}$ Swaleheen (2011) uses both GMM first difference and GMM system estimators to estimate the relationship between corruption and growth in a dynamic panel setting. I proceed with two-stage least squares since I am constrained to a cross-country setting.
} 


\begin{tabular}{|c|c|c|c|c|c|c|}
\hline & & $2000-2005$ & & & $2000-2011$ & \\
\hline & (1) & (2) & (3) & (4) & (5) & (6) \\
\hline CORRUPT_EXP & $\begin{array}{c}2.901 * \\
(1.461)\end{array}$ & $\begin{array}{l}4.321 * * \\
(1.942)\end{array}$ & $\begin{array}{c}4.126 * * \\
(2.030)\end{array}$ & $\begin{array}{c}3.044 * * \\
(1.396)\end{array}$ & $\begin{array}{c}5.053 * * * \\
(1.253)\end{array}$ & $\begin{array}{c}4.774 * * * \\
(1.534)\end{array}$ \\
\hline UNCERT & $\begin{array}{c}2.804 * * \\
(1.235)\end{array}$ & $\begin{array}{c}4.001 * * \\
(1.864)\end{array}$ & $\begin{array}{c}3.744 * * \\
(1.859)\end{array}$ & $\begin{array}{c}3.223 * * * \\
(1.111)\end{array}$ & $\begin{array}{c}4.670 * * * \\
(1.162)\end{array}$ & $\begin{array}{c}4.365^{* * * *} \\
(1.379)\end{array}$ \\
\hline CORRUPT_EXP $\times U N C E R T$ & $\begin{array}{c}-0.974 * * \\
(0.441)\end{array}$ & $\begin{array}{c}-1.390 * * \\
(0.548)\end{array}$ & $\begin{array}{c}-1.323 * * \\
(0.551)\end{array}$ & $\begin{array}{c}-0.997 * * \\
(0.416)\end{array}$ & $\begin{array}{c}-1.564 * * * \\
(0.358)\end{array}$ & $\begin{array}{c}-1.475 * * * \\
(0.419)\end{array}$ \\
\hline$E D U \_P R I M$ & $\begin{array}{c}0.077 \\
(0.246)\end{array}$ & $\begin{array}{l}-0.017 \\
(0.237)\end{array}$ & $\begin{array}{c}0.037 \\
(0.235)\end{array}$ & $\begin{array}{c}0.197 \\
(0.193)\end{array}$ & $\begin{array}{c}0.118 \\
(0.200)\end{array}$ & $\begin{array}{c}0.172 \\
(0.191)\end{array}$ \\
\hline POP_GROWTH & $\begin{array}{l}-0.332 \\
(0.467)\end{array}$ & $\begin{array}{l}-0.201 \\
(0.385)\end{array}$ & $\begin{array}{l}-0.216 \\
(0.409)\end{array}$ & $\begin{array}{l}-0.179 \\
(0.367)\end{array}$ & $\begin{array}{l}-0.040 \\
(0.323)\end{array}$ & $\begin{array}{l}-0.126 \\
(0.294)\end{array}$ \\
\hline INVEST & $\begin{array}{l}0.082 * \\
(0.047)\end{array}$ & $\begin{array}{l}0.076^{*} \\
(0.041)\end{array}$ & $\begin{array}{c}0.083^{* *} \\
(0.040)\end{array}$ & $\begin{array}{c}0.056 \\
(0.041)\end{array}$ & $\begin{array}{c}0.059 \\
(0.040)\end{array}$ & $\begin{array}{c}0.061 \\
(0.039)\end{array}$ \\
\hline OPEN & $\begin{array}{l}-0.170 \\
(0.552)\end{array}$ & $\begin{array}{c}0.104 \\
(0.408)\end{array}$ & $\begin{array}{l}-0.138 \\
(0.303)\end{array}$ & $\begin{array}{c}-0.466 \\
(0.594)\end{array}$ & $\begin{array}{l}-0.040 \\
(0.356)\end{array}$ & $\begin{array}{l}-0.212 \\
(0.320)\end{array}$ \\
\hline DEMOCRACY & $\begin{array}{l}-0.042 \\
(0.097)\end{array}$ & $\begin{array}{c}-0.153^{*} \\
(0.090)\end{array}$ & $\begin{array}{l}-0.116 \\
(0.073)\end{array}$ & $\begin{array}{c}-0.031 \\
(0.090)\end{array}$ & $\begin{array}{c}-0.154 * * \\
(0.068)\end{array}$ & $\begin{array}{c}-0.128 * * \\
(0.057)\end{array}$ \\
\hline FREEDOM & $\begin{array}{l}-0.040 \\
(0.399)\end{array}$ & $\begin{array}{c}0.021 \\
(0.330)\end{array}$ & $\begin{array}{l}-0.030 \\
(0.341)\end{array}$ & $\begin{array}{c}0.163 \\
(0.297)\end{array}$ & $\begin{array}{c}0.144 \\
(0.255)\end{array}$ & $\begin{array}{c}0.100 \\
(0.282)\end{array}$ \\
\hline SHADOW & $\begin{array}{c}0.023 \\
(0.020)\end{array}$ & $\begin{array}{c}0.021 \\
(0.015)\end{array}$ & $\begin{array}{l}0.025^{*} \\
(0.014)\end{array}$ & $\begin{array}{c}0.021 \\
(0.021)\end{array}$ & $\begin{array}{c}0.022 \\
(0.014)\end{array}$ & $\begin{array}{c}0.024 \\
(0.015)\end{array}$ \\
\hline COMMON_LAW & $\begin{array}{c}1.435 \\
(0.862)\end{array}$ & $\begin{array}{l}1.109 * * \\
(0.434)\end{array}$ & $\begin{array}{l}1.030 * * \\
(0.426)\end{array}$ & $\begin{array}{l}0.857 * \\
(0.465)\end{array}$ & $\begin{array}{c}0.426 \\
(0.315)\end{array}$ & $\begin{array}{c}0.385 \\
(0.309)\end{array}$ \\
\hline SOCIALIST & $\begin{array}{c}3.985^{* *} \\
(1.615)\end{array}$ & $\begin{array}{c}3.959 * * * \\
(1.379)\end{array}$ & $\begin{array}{c}3.759 * * \\
(1.479)\end{array}$ & $\begin{array}{c}2.912 * * \\
(1.130)\end{array}$ & $\begin{array}{c}2.622 * * \\
(1.038)\end{array}$ & $\begin{array}{c}2.330 * * \\
(1.096)\end{array}$ \\
\hline$G D P \_P C$ & $\begin{array}{l}-0.068 \\
(0.524)\end{array}$ & $\begin{array}{c}0.161 \\
(0.423)\end{array}$ & $\begin{array}{c}0.092 \\
(0.405)\end{array}$ & $\begin{array}{l}-0.392 \\
(0.398)\end{array}$ & $\begin{array}{l}-0.084 \\
(0.339)\end{array}$ & $\begin{array}{l}-0.182 \\
(0.302)\end{array}$ \\
\hline Obs. & 63 & 62 & 63 & 62 & 61 & 62 \\
\hline $\mathrm{R}^{2}$ & 0.714 & 0.680 & 0.677 & 0.666 & 0.598 & 0.602 \\
\hline F-Statistic & & 8.706 & 12.028 & & 10.510 & 11.244 \\
\hline J-Statistic & & 0.407 & - & & 0.098 & - \\
\hline $\begin{array}{l}\text { Notes: } *, * *, * * * \text { denote stat } \\
\text { parentheses; constant include } \\
\text { effects; specifications (2) and } \\
\text { for CORRUPT_EXP using } L\end{array}$ & $\begin{array}{l}\text { ignifica } \\
\text { regress } \\
\text { strumen } \\
D E \text { and } \\
\end{array}$ & $\begin{array}{l}\text { he } 1,5, \text { a } \\
\text { hough nc } \\
\text { ORRUPT } \\
\end{array}$ & $\begin{array}{l}\text { rcent le } \\
\text { d. Spec } \\
\text { ing } L A^{\prime}\end{array}$ & $\begin{array}{l}\text { oective } \\
\text { s (1) at } \\
\text { only; s }\end{array}$ & $\begin{array}{l}\text { ist standa } \\
\text { clude re } \\
\text { tions (3) }\end{array}$ & $\begin{array}{l}\text { s given in } \\
\text { xed } \\
\text { instrument }\end{array}$ \\
\hline
\end{tabular}

The first instrument included in this analysis is the absolute value of a country's latitude.

A common finding is that institutional quality and the geographical location of a country are correlated (e.g., Acemoglu et al., 2001; Hall and Jones, 1999). To the extent that overall institutional quality is representative of the level of corruption, we may see that countries further away from the equator also tend to experience lower levels of corruption. Thus, the absolute value of a country's latitude is likely going to be negatively correlated with current levels of corruption experience. 
In addition, it is unlikely that the absolute value of latitude is correlated with the error term. As argued in Acemoglu et al. (2001), the geographical environment set the stage for the types of institutions that were developed during colonial times. Given the persistence of institutions, these early colonial institutions formed the foundation for institutions in the present day. Consequently, studies that find that latitude has a direct impact on current economic performance often fail to control for institutional quality and are therefore simply picking the effects of institutional quality, rather than geography alone. Further, even if latitude is correlated initial levels of income, education, or institutions, it is unlikely that it would be associated with changes in any of these variables, e.g. growth rates.

The second instrument used in this paper is a proxy for the size of government, measured as government consumption expenditures as a percentage of GDP in $1999(G / G D P)$, as an instrument. Intuitively, the larger the size of government, the more opportunities there are for corruption. Thus, the size of government is likely positively correlated with corruption levels. In addition, it is unlikely that the size of government alone has a direct impact on growth. As argued in Bergh and Henrekson (2011), countries that have large governments, yet more economic freedom may have very different growth outcomes than countries with large governments with little economic freedom. Thus, it is reasonable to assume that government size, alone, in 1999 is unrelated to growth past 2000.

Therefore, this paper argues that these instruments are valid. As can be seen in specification (2) and (5) of the tables, the first-stage F-statistics always rejects the weak instrument null hypothesis according to the Stock and Yogo (2005) critical values and the Jstatistics indicate no evidence to reject the exogeneity of the instruments. However, due to $G \_G D P$ potentially having its own impact on economic growth specification (3) and (6) exclude 
$G_{-} G D P$ as an instrument, despite the J Statistic failing to reject exogeneity of the instruments. Note that the F-statistic still rejects the weak instrument null hypothesis, but we cannot estimate a J-statistic since the equation is just identified. Importantly, in all specifications, the sign and statistical significance of CORRUPT_EXP and CORRUPT_EXP $\times$ UNCERT remain unchanged. Thus, although the availability of instruments is limited, this provides further evidence that the relationship between corruption and growth is highly dependent upon the level of uncertainty involved.

\subsection{Conclusion}

The question of whether corruption is good or bad for growth may seem like an obvious one. However, the empirical literature estimating the consequences of corruption is mixed. This paper argues that the mixed results in the previous literature stem from the fact that uncertainty regarding corruption is not controlled for. The type of corruption regime determines the level of the uncertainty involved, which consequently determines if corruption is good or bad for growth. Corruption may be beneficial for economic growth, for example by using bribes to get around inefficient regulations as described above, as long as the uncertainty regarding this corruption is minimal.

Overall, this paper finds that relationship between corruption experience and growth is highly dependent upon the level of uncertainty involved. At very low levels of uncertainty, corruption experience is found to have a positive relationship with growth. However, this effect is quickly offset by increases in uncertainty.

Over a five-year period, the estimated marginal effect of corruption experience on growth is negative for over 60 percent of the sample, and statistically significant and negative for 45 percent of the sample. Similarly, over an eleven-year period the marginal effect of corruption 
experience on growth is negative for over 58 percent of the sample and statistically significant and negative for 45 percent of the sample. Thus, corruption seems to have a negative relationship with growth for a majority of the sample.

Furthermore, these effects become economically large at extreme values of uncertainty and corruption. For example, at the sample maximum level of uncertainty, a one unit increase in CORRUPT_EXP(equivalent to moving from Sweden to the United States), is associated with a decrease in GROWTH by 2.945 percentage points, which is more than the entire mean of GROWTH for the overall sample. Thus, in countries that experience the most uncertainty, corruption will likely have a strong negative impact. 


\section{Chapter 3}

\section{The Effect of Informal Employment and Corruption on Income Levels in Brazil}

\subsection{Introduction}

Corruption is considered to be a major detriment to development, particularly in low-income countries. In a review of the literature, Olken and Pande (2012) summarize the ways in which corruption has been measured and show that no matter how dramatically the estimates differ there is a strong negative association between income levels and corruption. ${ }^{20}$ A major explanation for this finding is that corruption induces uncertainty, decreasing incentives for investment, thereby reducing future income (Shleifer and Vishny, 1993; Wei, 1997; Campos et al., 1999; Bologna, 2016).

An alternative, less direct, explanation of this finding is that corruption has an impact on the size of the informal sector (shadow economy) and the size of the informal sector subsequently impacts income levels and growth rates (La Porta and Shleifer, 2008). Specifically, in lower-income countries, corruption and the informal sector are found to be complements and therefore a higher level of corruption translates into a larger informal sector (Dreher and Schneider, 2010). Furthermore, it is highly plausible that the unofficial economy and the official economy are substitutes, rather than complements, in lower income countries causing the official economy to suffer when the unofficial economy is large (Dreher and Schneider, 2010; Johnson et al., 1997). Therefore, it could be the case that we see this strong negative association between low-income countries and high corruption levels partly because corruption is driving individuals

\footnotetext{
${ }^{20}$ This finding is common in much of the empirical literature (e.g., Li, Xu, and Zou, 2000; Mo, 2001; Abed and Davoodi, 2002; Treisman, 2007; Aidt, 2009), though corruption's impact on growth is less agreed upon (see, Bologna (2016), for a review of the growth literature).
} 
to participate in the informal sector, seemingly lowering income and GDP per-capita due to its negative impact on the formal economy alone.

The negative relationship between corruption and income levels is well-documented, and numerous papers also link corruption to the size of the shadow economy (Johnson et al., 1997; Hindriks et al., 1999; Hibbs and Piculescu, 2005; Dreher et al., 2009; Dreher and Schneider, 2010). However, empirical studies that explicitly incorporate the effect of the informal sector when estimating the relationship between corruption and economic outcomes at the aggregate level are scarce and there are virtually no studies that incorporate this effect within a specific country. ${ }^{21}$ For example, broad surveys of the corruption literature rarely mention the informal sector, other than the fact that its size may be influenced by corruption (e.g., Dreher and Herzfeld, 2005; Treisman, 2007). Thus, if the informal sector has a significant impact on economic outcomes and if corruption and the informal sector are significantly correlated, the previous empirical results are potentially biased. A primary contribution of this paper is to exploit a unique data set on corruption and informal sector employment in 476 Brazilian municipalities to estimate whether corruption impacts income levels once variation in informal economic activity is taken into account.

The size of the informal sector in Brazil is extremely large. Both employment and incomes from the informal sector are included in each decennial Census, making this an ideal country for this specific type of analysis. In the sample of municipalities used in this paper, the size of the Brazilian informal sector in 2000, as measured by share of employees without a formal contract, was over 50 percent of total employees. Furthermore, informal sector employees

\footnotetext{
${ }^{21}$ Dreher and Gassebner (2013) conduct a cross-sectional analysis and include the size of the informal sector in addition to corruption measures when examining how corruption impacts entrepreneurship, finding no change in their results. Wiseman (2014) argues that corruption only impacts entrepreneurship through its effect on the shadow economy within the United States, but does not include both effects in a single regression.
} 
accounted for almost 40 percent of total income from employees of all types in these municipalities. Thus, it is clear that the informal sector is an integral part of the Brazilian economy.

In addition, corruption in Brazil has long been a serious problem. Due to a number of scandals exposing specific politician's behavior in the latter half of the $20^{\text {th }}$ century, Brazil is recognized as a country that is suffering from corrupt acts (Geddes and Neto, 1992; Silva, 1999). In order to combat corruption, in May of 2003, the government of Luiz Inácio Lula da Silva implemented a program based on random auditing of municipal governments' expenditures (Ferraz and Finan, 2008; Ferraz and Finan, 2011). This program randomly selects about one percent of the total number of municipalities with a population less than 500,000 (ControladoriaGeral da União (CGU)). The CGU auditors collect information on all federal funds transferred to the municipal government, inspects public work construction, and consults the population through community councils on any complaints of misconduct (CGU). This collected information is then organized into a report and made available to the public.

In a series of papers, Claudio Ferraz and Frederico Finan used these reports to construct measures of corruption in the audited municipalities $(2008 ; 2011)$. This paper uses the corruption indicators developed in their 2011 paper, specifically. Ferraz and Finan (2011) focus on three different types of corruption that could be found in these audit reports: fraud in the public procurement of goods and services, diversion of funds, and the over invoicing of goods and services. They estimate that corruption in these local governments alone amounts to be about $\$ 550$ million per year.

The main corruption variable of interest is the share of total federal resources ( $R$ \$) that is associated with any of these three types of corruption. As can be seen in figure 3.1, this 
corruption variable is negatively related to average incomes of both formal and informal

workers. $^{22}$ This figure also shows that, on average, formal employees have higher incomes than informal employees and that corruption has more of a negative impact on the informal sector than the formal.

Figure 3.1: The relationship between corruption, as measured by the share of resources (R $\$$ ) found to involve corruption, and formal and informal incomes per-worker.

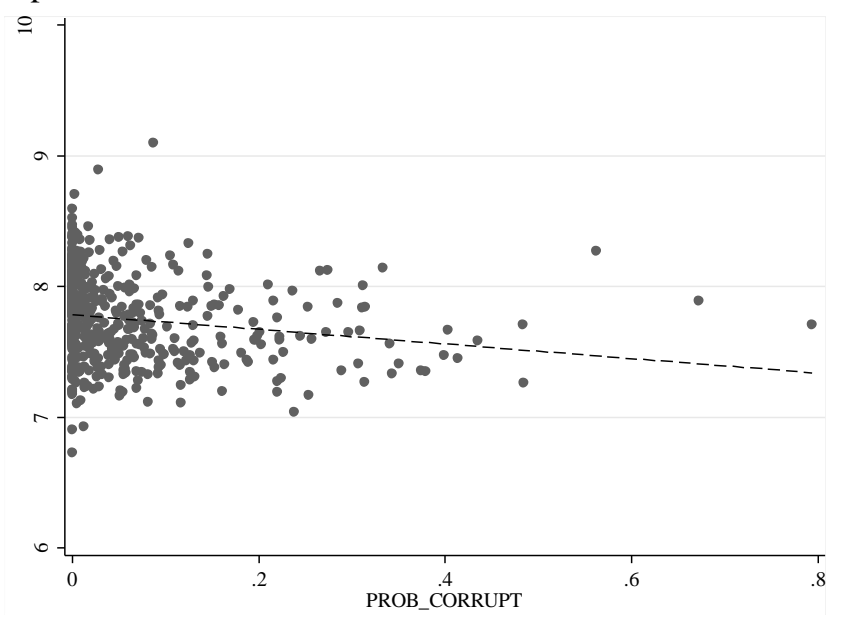

Sources: Formal and informal incomes per-capita (FORMAL_INCOME; INFORMAL_INCOME) from IBGE Census 2000 and the share of resources $\mathrm{R} \$$ involving corruption (PROB_CORRUPT) from Ferraz and Finan (2011).

Figure 3.2: The relationship between corruption, as measured by the share of resources (R $\$$ ) found to involve corruption, and the size of the informal economy is 2000 .

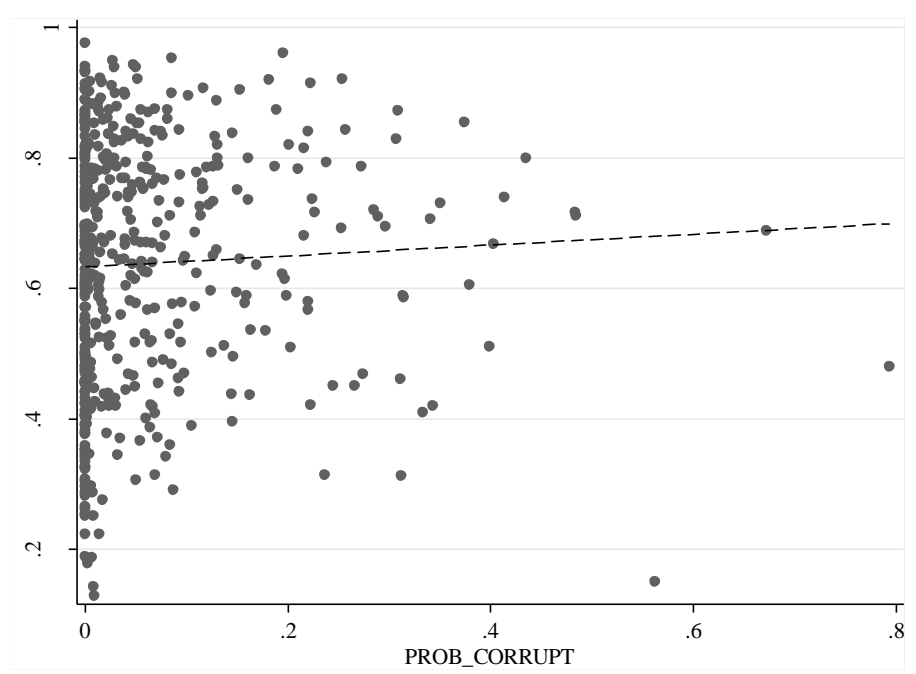

Sources: Size of informal economy (SIZE_INFORMAL), as measured by share of employees without a formal contract, from IBGE Census 2000 and the share of resources R\$ involving corruption (PROB_CORRUPT) from Ferraz and Finan (2011).

\footnotetext{
${ }^{22}$ Data will be explained in further detail in the data section.
} 
Furthermore, as figure 3.2 shows, a higher level of corruption is associated with an increase in the size of the informal sector, although this positive relationship is relatively small in magnitude. Taken together, these figures suggest that even if corruption and the informal sector are complementary in the sense that corruption induces individuals to participate in the informal sector as in Dreher and Schneider (2010), these individuals are worse off regardless of being formally or informally employed in the presence of more corruption.

If the size of the informal sector has its own direct impact on the income levels of both the formally and informally employed, this could potentially bias the relationship between corruption and income levels. Some researchers argue that the official economy and the unofficial economy are complementary, and therefore an increase in the informal sector is not necessarily bad for economic growth (Choi and Thum, 2005). Schneider and Enste (2000) estimate that about two-thirds of the income earned in the informal sector is immediately spent in the formal economy, therefore causing there to be positive spillovers. However, others argue that reducing the shadow economy would lead to a significant increase in the tax base leading to higher quality public services and economic growth (Loayza, 1996). Researchers also argue that the informal sector distorts competition and prevents more efficient formal firms from gaining market share, consequently decreasing economic growth (Farrell, 2004).

La Porta and Shleifer (2008) summarize the above views of researchers into three broad categories: (1) a romantic view, (2) a parasitic view, and (3) a dual view. In regards to the first view, the informal sector consists of firms and individuals that are extremely similar in productivity (i.e., have similar characteristics) to the formal sector, however are only held back by governmental policies and practices. ${ }^{23}$ In this case, wages in both the formal sector and the

\footnotetext{
${ }^{23}$ Given the importance of these policies and practices in determining whether individuals work in the formal or informal sector, governmental institutions are controlled for in the analysis of this paper.
} 
informal sector would be fairly similar and a movement from the formal sector to the informal sector shouldn't have a large impact on the total amount produced. However, as shown in figure 3.1, formal employees earn more income on average. In addition, as shown in figure $\mathbf{3 . 3}$ municipalities with larger informal economies have lower levels of income in general. Thus, it is unlikely the case that the romantic view is the reality in Brazil.

Figure 3.3: The relationship between the size of the informal economy in 2000 and formal and informal incomes perworker in 2000.
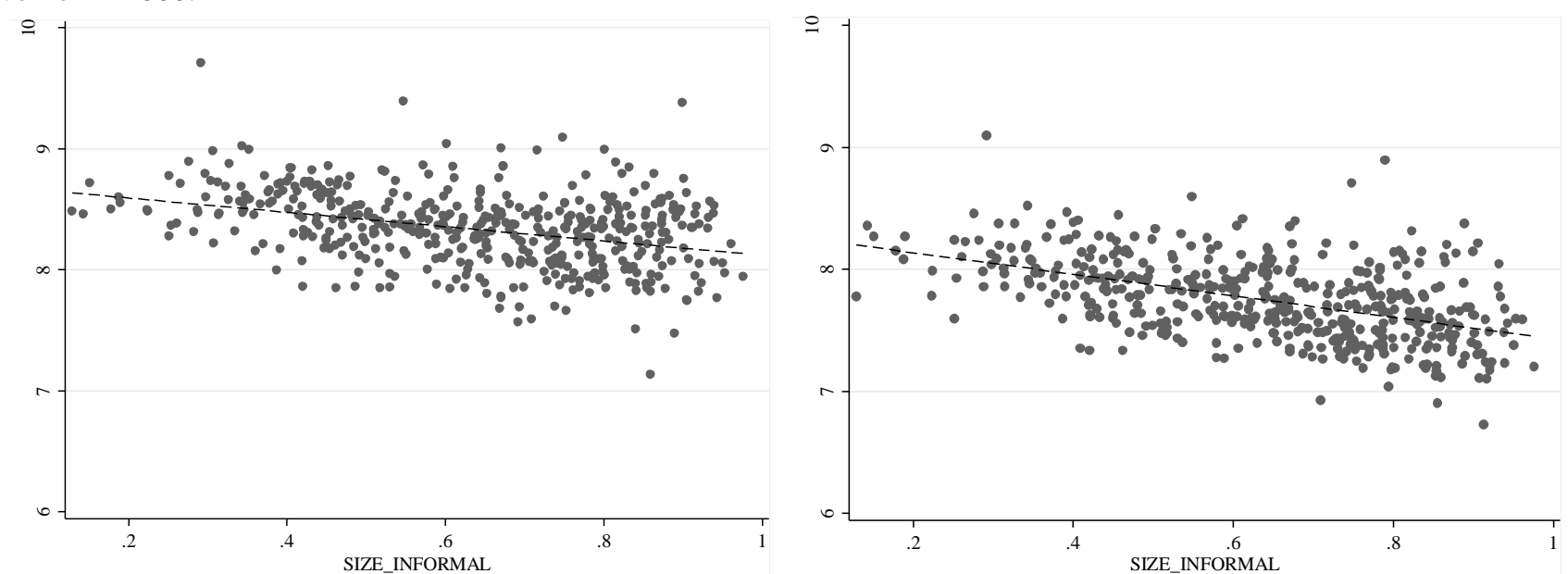

Sources: Formal and informal incomes per-capita (FORMAL_INCOME; INFORMAL_INCOME) as well as the size of the informal economy, as measured by SIZE_INFORMAL from IBGE Census 2000.

The parasitic and dual views both argue that informal firms are far less productive than

formal firms. This is likely due to the fact that the informal sector is labor intensive, while the formal sector is capital intensive. However, the parasitic view argues further that these informal firms actually have negative effects on the formal sector, while the dual view contends that these informal firms are far too small to have a negative impact on the formal sectors. The informal sector allows individuals to operate under the radar of government supervision. This means, for example, that individuals in this sector can avoid paying taxes, but it also means that they have are unable to consume certain public services. ${ }^{24}$ Researchers that support the dual view believe

\footnotetext{
${ }^{24}$ For example, because of their informal status individuals in the informal sector do not have full and enforceable property rights over their product (Braun and Loayza, 1994).
} 
that the informal sector is a good thing in developing countries, where the quality of public service is low, as it gives individuals a type of refuge. La Porta and Shleifer (2008) find the most evidence in support of the dual view when looking at a cross-section of countries.

As can be seen in figure $\mathbf{3 . 3}$, the size of the informal sector is negatively related to average incomes of both formal and informal workers, but has a stronger effect on the latter. The increase in the relative number of informal employees may be driving the wage down in the informal sector; however, all else equal this should also be increasing or leaving the wages in the formal sector unchanged, however the opposite is true. This is suggesting that the parasitic view may be the most relevant in Brazil. In the case of the Brazilian economy these informal, less productive, firms may actually take up a large enough share of the market to have a negative impact on the formal sector. In either case, it is clear that controlling for the size of the informal sector is important when estimating the relationship between corruption and income levels.

The relationships given in figures 3.1 through $\mathbf{3 . 3}$ are simply bivariate relationships, however, and may be excluding important factors. The goal of this paper is to closely examine these relationships, while controlling for a variety of factors that are found in the literature to have an impact on income levels. Specifically, I estimate how the level of corruption and the size of the informal sector impact GDP per-capita and both formal and informal income per-worker, while controlling for an additional 19 variables. Furthermore, I check the robustness of these results by including a variety of fixed effects, as well as supplementing with an instrumental variable analysis.

As a preview of the results, this paper finds that while corruption tends to have a negative association with GDP per-capita and income levels, this relationship is largely statistically insignificant. However, the size of the informal sector has a negative and robustly significant 
relationship with GDP per-capita and average income from all sources of employment (both formal and informal). This is therefore suggesting that the size of the informal sector may be more important in determining income levels than corruption. Furthermore, even if informal employment is a relevant alternative to formal employment and results in positive spillovers into the formal economy, society as a whole is worse off in the face of a larger informal sector since both GDP per-capita and total incomes are lower.

A further review of the literature is described in 2; section 3 presents the data and empirical methodology; section 4 summarizes the results; section 5 concludes.

\subsection{Measuring Corruption and the Informal sector}

As emphasized in Olken and Pande (2012), the ideal way to measure corruption is by direct observation; however, due to corruption's secretive nature this is obviously difficult. Until recently, much of the literature on corruption has focused on cross-country comparisons between corruption perceptions and economic growth (e.g., Mauro, 1995). Nevertheless, these perception indices have been shown to be biased at both the macro level (Donchev and Ujhelyi, 2014) and at the micro level (Olken, 2009). Perceptions of corruption can easily be influenced by factors other than corruption, such as the level of incomes or education in each country. Furthermore, corruption perceptions are rather difficult to compare across countries. Given this, the use of more experience based measures of corruption has been emphasized at the aggregate level, the most common of which is an index of bribe payers (Treisman, 2007; Bologna, 2016).

However, while bribes represent a more direct measure of corruption, these aggregate measures are largely survey based and could still be biased. Given this, there have been several micro based studies that attempt to measure corruption through direct observation of bribes (e.g., McMillan and Zoido, 2004; Olken and Barron, 2009; Sequeria and Djankov, 2010) or by 
estimating theft of public resources (e.g., Reinikka and Svensson, 2004; Olken, 2007). However each of these micro based studies typically focuses on specific categories of public services such as education (Reinikka and Svensson, 2004) or public infrastructure (Olken, 2007).

The measure of corruption used in this paper is based on instances of corruption in Brazilian municipalities using audit reports that are made available to the public. This measure of corruption is unlikely to suffer from the biases of the perception indices, as it is estimating corruption from actual incidences of corruption. Furthermore, it is a much broader measure of corruption than bribes or theft of a specific type of government expenditure alone as it includes corruption in all types of government expenditures, rather than focusing on exclusive categories.

As explained in Ferraz and Finan (2011), Brazil is one of the most decentralized countries in the world, with local governments receiving about $\$ 35$ billion per year from the federal government to provide public services. The mayor and the local legislators are relatively free to decide how to spend these resources, allowing a great deal of room for corruption. The three most common ways in which local politicians can engage in corruption are fraud in the procurement in public services, diversion of funds, and over invoicing public services. As an example, Ferraz and Finan (2011) explain mayors often divert funds intended for public service projects, such as education, toward the purchases of personal items for either themselves or for their friends and family. ${ }^{25}$

Given the discretion allowed in the municipal governments, it is not surprising that there is a vast amount of corruption in the Brazilian municipalities. In order to combat this corruption, in May 2003, Luiz Inácio Lula da Silva implemented an anticorruption program based on random auditing of municipal expenditures. Out of a total of about 5,500 municipalities 50-60

\footnotetext{
${ }^{25}$ See Ferraz and Finan (2011) for further details on the political processes in Brazilian municipalities and for more examples of corruption occurring in these municipalities.
} 
are chosen to be audited on a monthly basis (CGU). Municipalities with more than 500,000 inhabitants cannot be chosen, therefore excluding approximately 8 percent of the municipalities (Ferraz and Finan, 2011). Furthermore, to ensure a fair and truly random process, individuals are invited to witness each lottery.

Once a municipality is chosen, approximately $10-15$ CGU auditors gather information on all federal funds transferred to the municipal government from 2001 onward. The results of each audit are made publicly available. Although the audit program is still in existence today, the dataset used in Ferraz and Finan (2011) uses audits only for the first eleven months of the program, or the first 11 lottery draws. Therefore, although Olken and Pande (2012) argue that the results of these audit reports need to be interpreted with caution as it represents both actual corruption and the inability to hide corruption from auditors, it unlikely that this would be a large issue using only the earliest audits, rather than the most recent ones.

As mentioned above, corruption is not the whole story when it comes to determining its effect on GDP and income levels. Although the literature is somewhat mixed as to the exact direction of the relationship, corruption and the informal (shadow) economy are clearly related. Some argue that since the option of entering into the shadow economy can act as a constraint on politicians' behavior, corruption and the informal economy are substitutes for one another (Choi and Thum, 2005; Dreher et al., 2009). However, others argue that if the option of participating in the informal sector is plausible then corruption may drive entrepreneurs underground. In this case, corruption is often needed to expand the informal sector and therefore we may actually see that corruption and the informal sector are complementary (Johnson et al., 1997; Hindriks et al., 1999; Hibbs and Piculescu, 2005). 
Dreher and Schneider (2010) argue that the relationship between corruption and the informal sector depends on the level of income or development of the specific country in question. Using the World Bank's definition of income classes, Dreher and Schneider (2010) break their sample up into two groups: low income and high income. Specifically, countries are classified as low income if their 2004 GNI per-capita is less than US $\$ 3,255$. Using this classification, Dreher and Schneider (2010) find that corruption and the informal sector are complements for countries in the low income group and substitutes for countries in the high income group.

Given that Brazil's 2004 GNI per-capita is approximately US $\$ 3,310$ (World Bank), Brazil is a country that just missed the low income cutoff point in the Dreher and Schneider (2010) analysis. From 2001 - 2003 the GNI per-capita in Brazil was actually less than the low income cutoff point of US $\$ 3,255$. Since the corruption data is measuring the level of corruption from 2001- 2003, it is likely that Brazil falls into the low income group where corruption and the informal sector are complementary. Thus, in the case of Brazil it is likely that an increase in corruption corresponds to an increase in the size of the informal sector.

Since the informal sector is likely to have its own impact on development (see, e.g., Schneider and Estne, 2000; La Porta and Shleifer, 2008), it is important to incorporate the informal sector into the analysis as well when looking at corruption-income level relationships. This leads to the question of how to properly measure the size of the informal sector. As noted in Schneider and Estne (2000), Schneider (2005), and Schneider (2007), a precise definition of the shadow, or informal, economy is still lacking. The informal sector includes both legal activities, such as unreported income related to the production of legal goods and services, as well as illegal activities, such as trade in stolen goods. A common working definition is to include all market- 
based production of legal goods and services that are deliberately concealed from public authorities (see, e.g., Schneider and Williams, 2013). ${ }^{26}$

Given the availability of data in Brazil, this paper will use a slightly different, yet simpler, definition of the size of the informal sector. Each Brazilian Census includes data on all "types" of employees in the production of goods and services in all legal sectors of the economy- both formal and informal. Consistent with the definition used in the methodology of constructing GDP in Brazilian municipalities, this paper will define informal employees as the difference between the total number of employees and employees with a formal contract (Instituto Brasileiro de Geografia e Estatística - IBGE). Therefore, these informal employees are engaged in legal productive activities that contribute to the calculation of GDP; however, they are mostly non-tax payers. Specifically, only nine percent of employees without a formal contract are taxpayers of pension (IBGE). Thus, rather than using value-added estimates of these employees as the size of the informal sector, this paper will simply use the relative share of total employment allocated to the informal sector. This gives a simple idea of how large the informal sector is in the Brazilian economy.

\subsection{Methodology \& Data}

The goal of this paper is to estimate the effect corruption has on economic outcomes, while incorporating the effects of the informal sector, using municipalities as the unit of analysis. Economic outcomes are measured first using an estimate of GDP per-capita in each municipality. However, given that the informal sector is unlikely to be fully incorporated into estimates of GDP, it is important to check the robustness of this result with total income from both formal and

\footnotetext{
${ }^{26}$ As noted in Pederson (2003), it is important to understand that a portion of these unofficial activities are already incorporated into officially calculated national account measures so value estimates of the informal sector does not necessarily mean that the official measures are underestimated by exactly that amount.
} 
informal employment taken together, and with income from formal and informal employment separately. Formal employees are employees hired with a formal contract and those hired without a formal contract are referred to as informal. Therefore, this paper will estimate the following:

$$
\text { (3.3.1) } y_{i, t}=\alpha_{0}+\alpha_{1} \text { CORRUPT_MEASURE } E_{i}+\alpha_{2} S I Z E_{\_} I N F O R M A L_{i}+\theta X_{i}+\varepsilon_{i},
$$

where $i$ represents each municipality as the unit of observation, $y$ is one of the four measures of economic output at time $t$ as described briefly above and in detail below, CORRUPT_MEASURE is one of the two measures of corruption described in detail below, SIZE_INFORMAL is the relative share of total employees without a formal contract, $X$ is a matrix of additional controls, and $\varepsilon$ is the error term.

The data for this paper comes from three different sources: Instituto Brasileiro de Geografia e Estatística (Brazilian Institute of Geography and Statistics - IBGE), Instituto de Pesquisa Econômica Aplicada (Institute of Applied Economic Research - IPEA), and Ferraz and Finan (2011). All dependent variables and controls, other than the measure of corruption, come from either IBGE or IPEA. The corruption measures come from Ferraz and Finan (2011). I will first discuss the construction of the dependent variables, following by independent variables. Dependent variable descriptions are summarized in table 3.1. 


\begin{tabular}{|c|c|c|c|}
\hline Variable & Description & Year & Source \\
\hline \multicolumn{4}{|c|}{ Dependent Variables } \\
\hline \multicolumn{4}{|c|}{ GDP per-capita } \\
\hline GDP_PC_04 & GDP per-capita for years 2004. & 2004 & IPEADATA \\
\hline$G D P_{-}^{-} P C_{-} 10$ & GDP per-capita for years 2010 . & 2010 & IPEADATA \\
\hline \multicolumn{4}{|l|}{ Types of Income } \\
\hline TOTAL_OO & Average yearly income per employees from main job. & 2000 & Census \\
\hline FORMAL_OO & Average yearly income per employees with formal contracts only. & 2000 & Census \\
\hline INFORMAL_OO & Average yearly income per employees without formal contracts only. & 2000 & Census \\
\hline TOTAL_10 & Average yearly income per employees from main job. & 2010 & Census \\
\hline FORMĀL_10 & Average yearly income per employees with formal contracts only. & 2010 & Census \\
\hline INFORMĀL 10 & Average yearly income per employees without formal contracts only. & 2010 & Census \\
\hline
\end{tabular}

The first dependent variable of interest is simply GDP per-capita for each municipality put into R $\$ 2000$ dollars by the IPEA. Municipal GDP is calculated by the IBGE and made available by IPEADATA. This data is given annually from 2000 until 2010. Thus, since the corruption incidences that form the data of this paper take place mainly in 2001-2003, it makes sense to look at subsequent GDP per-capita levels in 2004. Furthermore, as corruption is often argued to have differing short-term and long-term relationships checking robustness with the most recent year available (2010) is also necessary (Aidt, 2009).

Looking at the relationships between GDP per-capita, corruption, and the informal sector will give some indication of how corruption and the informal sector influence official estimates of GDP. The estimates of GDP in each municipality explicitly includes value added in the construction industry from employees employed informally, accounting for approximately 70 percent of employment in that sector (IBGE). Thus, indicating that the IBGE is attempting to incorporate the informal sector into its official estimates. However, as mentioned in Pederson (2003), while official estimates of GDP are able to capture a portion of the informal sector, they are likely going to under-estimate "total" output if the size of the informal sector is significant. 
Since, on average, over 60 percent of employees fit the definition of informal as defined in this paper and in the GDP methodology, the GDP estimate is likely biased.

Therefore, these results are supplemented with average total income per-worker estimates that come from the IBGE Census in 2000 and in 2010. Total income is defined as the average yearly income employees, of any type, receive from their main job. Thus, this is a per-worker measure, rather than a strict per-capita measure. Furthermore, both the Census in 2000 and 2010 split this average income into several different types of employees. The incomes of the two types of employees that this paper is focused on are employees hired with a formal contract and those hired without a formal contract. The former are referred to as formal employees, and the latter are referred to as informal employees. As can be seen in table 3.2, in both 2000 and 2010, employees hired with a formal contract make almost double what those employees hired without a formal contract make. This paper will first estimate the relationship between corruption, the informal sector, and incomes in 2000, and then supplement these results with incomes in 2010. The latter estimates, as well as a supplemental IV analysis, will allow more causal arguments to be made.

\begin{tabular}{|c|c|c|c|c|c|c|}
\hline Variable & Year & Obs. & Mean & $\begin{array}{l}\text { Std. } \\
\text { Dev. }\end{array}$ & Min & $\operatorname{Max}$ \\
\hline \multicolumn{7}{|c|}{ Dependent Variables } \\
\hline \multicolumn{7}{|l|}{ GDP per-capita } \\
\hline$G D P \_P C \_04$ & 2004 & 476 & 4819 & 7951 & 829 & 124638 \\
\hline$G D P \_P C_{-} 10$ & 2010 & 476 & 5904 & 9232 & 1055 & 129629 \\
\hline \multicolumn{7}{|l|}{ Types of Income } \\
\hline TOTAL_OO & 2000 & 476 & 3497 & 1308 & 1311 & 14843 \\
\hline FORMAL_OO & 2000 & 476 & 4369 & 1457 & 1257 & 16466 \\
\hline INFORMAL_OO & 2000 & 476 & 2454 & 885 & 838 & 8927 \\
\hline TOTAL_10 & 2010 & 476 & 4014 & 1157 & 2058 & 12804 \\
\hline FORMAL_10 & 2010 & 476 & 4612 & 1026 & 2718 & 13788 \\
\hline INFORMAL_10 & 2010 & 476 & 2768 & 766 & 1363 & 7593 \\
\hline
\end{tabular}


Independent variable, and instrumental variable, descriptions are summarized in table

3.3. The main corruption variable used in this paper, from Ferraz and Finan (2011), is defined as the share of audited resources $(\mathrm{R} \$)$ found to involve corruption (PROB_CORRUPT). This gives an idea of the proportion of federal resources that are involved in corrupt acts. However, since a dollar value was not available for every single instance of corrupt acts, Ferraz and Finan (2011) also use the share of audited items found to involve corruption (PROB_CORRUPT_2) as an alternative measure of corruption. This second measure gives an idea of the frequency of corrupt transactions, whereas the first measure gives more of an idea of how serious these transactions were, in terms of their value.

Table 3.3: Independent variable and instrumental variable brief descriptions.

\begin{tabular}{|c|c|c|c|}
\hline Variable & Description & Year & Source \\
\hline \multicolumn{4}{|l|}{ Independent Variables } \\
\hline \multicolumn{4}{|c|}{ Corruption \& Informal Sector Measures } \\
\hline PROB_CORRUPT & Share of audited resources ( $\mathrm{R} \$$ ) found to involve corruption. & 2001-04 & $\mathrm{F} \& \mathrm{~F}(2011)$ \\
\hline PROB_CORRUPT_2 & Share of audited items found to involve corruption. & 2001-04 & $\mathrm{F} \& \mathrm{~F}(2011)$ \\
\hline MISMANAGE & Proportion of irregularities associated with mismanagement. & 2001-04 & $\mathrm{F} \& \mathrm{~F}(2011)$ \\
\hline SIZE_INFORMAL & Share of total employees without a formal contract. & 2000 & Census \\
\hline \multicolumn{4}{|l|}{ Basic Controls } \\
\hline INSTITUTION & Index of institutional quality; scale of 1 (poor institutions) to 6 (superior institutions). & 1997-00 & Census \\
\hline POPULATION & Total population, enters regressions in logged form. & 2000 & Census \\
\hline$U R B A N$ & Share of urban population. & 2000 & Census \\
\hline DENSITY & People per square mile, enters regressions in logged form. & 2000 & Census \\
\hline TEEN & Share of population between ages $10-19$. & 2000 & Census \\
\hline WORK & Share of population between ages $20-59$. & 2000 & Census \\
\hline ELDER & Share of population age 60 or over. & 2000 & Census \\
\hline SCHOOL & Average \# of years of schooling population 10 years or older. & 2000 & Census \\
\hline AGRICULTURE & Share of employment in agricultural sector. & 2000 & Census \\
\hline CONSTRUCTION & Share of employment in construction sector. & 2000 & Census \\
\hline MANUFACTURING & Share of employment in manufacturing sector. & 2000 & Census \\
\hline$T R A D E$ & Share of employment in trade sector. & 2000 & Census \\
\hline TRANSPORT & Share of employment in transportation sector. & 2000 & Census \\
\hline SERVICES & Share of employment in services sector. & 2000 & Census \\
\hline PROVISION & Share of employment in the provision of services sector. & 2000 & Census \\
\hline SOCIAL & Share of employment in the social services sector. & 2000 & Census \\
\hline GOVERNMENT & Share of employment in the government sector. & 2000 & Census \\
\hline OTHER & Share of employment in other activities sector. & 2000 & Census \\
\hline DISTANCE_SP & (Log) min. cost of transport to São Paulo Municipal Headquarters index & 1995 & IPEADATA \\
\hline \multicolumn{4}{|l|}{ Instrumental Variables } \\
\hline$R A I N$ & Quarterly averages of rainfall of summer months Dec. - Feb. (mm). & $1961-90$ & IPEADATA \\
\hline TEMP & Quarterly averages of temperature of summer months Dec. - Feb. $\left({ }^{\circ} \mathrm{C}\right)$. & $1961-90$ & IPEADATA \\
\hline
\end{tabular}


As can be seen in table 3.4, there is a great amount of variation across municipalities in their levels of corruption. Approximately 6 percent of resources are found to involve corruption in the sample, however, this number gets as large as 80 percent of resources and as low as 0 percent of resources in some municipalities.

\begin{tabular}{|c|c|c|c|c|c|}
\hline Variable & Obs. & Mean & $\begin{array}{c}\text { Std. } \\
\text { Dev. }\end{array}$ & Min & Max \\
\hline \multicolumn{6}{|l|}{ Independent Variables } \\
\hline PROB_CORRUPT & 476 & 0.063 & 0.102 & 0.000 & 0.794 \\
\hline$P R O B \_C O R R U P T \_2$ & 476 & 0.052 & 0.052 & 0.000 & 0.323 \\
\hline MISMANAGE & 366 & 1.624 & 1.624 & 0.000 & 8.000 \\
\hline \multicolumn{5}{|l|}{ Basic Controls } & 0.977 \\
\hline INSTITUTION & 476 & 2.979 & 0.545 & 1.400 & 4.500 \\
\hline POPULATION & 476 & 25412 & 40598 & 1270 & 449476 \\
\hline$U R B A N$ & 476 & 0.601 & 0.231 & 0.119 & 1.000 \\
\hline DENSITY & 476 & 320 & 2072 & 0.662 & 33,072 \\
\hline TEEN & 476 & 0.223 & 0.027 & 0.144 & 0.284 \\
\hline WORK & 476 & 0.473 & 0.052 & 0.336 & 0.579 \\
\hline ELDER & 476 & 0.088 & 0.026 & 0.031 & 0.214 \\
\hline SCHOOL & 476 & 4.332 & 1.188 & 1.178 & 8.504 \\
\hline AGRICULTURE & 476 & 0.398 & 0.208 & 0.000 & 0.899 \\
\hline CONSTRUCTION & 475 & 0.055 & 0.031 & 0.003 & 0.284 \\
\hline MANUFACTURING & 472 & 0.08 & 0.076 & 0.002 & 0.507 \\
\hline TRADE & 475 & 0.091 & 0.045 & 0.009 & 0.27 \\
\hline TRANSPORT & 475 & 0.029 & 0.015 & 0.001 & 0.086 \\
\hline SERVICES & 434 & 0.015 & 0.019 & 0.000 & 0.227 \\
\hline PROVISION & 476 & 0.134 & 0.066 & 0.008 & 0.441 \\
\hline SOCIAL & 475 & 0.077 & 0.03 & 0.030 & 0.203 \\
\hline GOVERNMENT & 476 & 0.054 & 0.035 & 0.035 & 0.278 \\
\hline OTHER & 476 & 0.058 & 0.028 & 0.028 & 0.182 \\
\hline DISTANCE_SP & 476 & 1913 & 1311 & 68.063 & 8,582 \\
\hline \multicolumn{6}{|l|}{ Instrumental Variables } \\
\hline$R A I N$ & 433 & 120 & 41 & 37 & 241 \\
\hline TEMP & 433 & 25 & 2 & 17 & 29 \\
\hline
\end{tabular}

Since not all municipalities in the sample were selected in the same lottery, lottery fixed effects are included in some regressions to check for robustness. It is possible that an exogenous event occurred at the time of being selected for a lottery affecting both income and corruption levels in that sample of municipalities. If this is the case, then we may see a significant 
relationship between incomes and corruption simply because of the timing of the audits, not necessarily because of any causal relationship.

In addition to these main corruption variables, Ferraz and Finan (2011) develop an alternative measure of corruption associated with less blatant acts of corruption and more broadly inclusive of acts of mismanagement in general. They argue that these types of violations are less visible, yet may still be associated with acts of corruption. Essentially, any violation of a standard rule or procedure is recorded as an act of mismanagement. An example Ferraz and Finan (2011) give is in the procurement of public goods, at least three firms have to bid for the contract. When less than three firms bid, yet the good is still provided, this is coded as an act of mismanagement. To get a relative measure of mismanagement across municipalities, Ferraz and Finan (2011) divide the total number of violations by the total number of service items audited $(M I S M A N A G E) .{ }^{27}$ This variable will be included in the regressions as a robustness check. If politicians do attempt to hide their blatant acts of corruption from the auditors, these acts are more likely to be uncovered using this variable.

As mentioned in the previous section the size of the informal sector will be defined as the difference between the total number of employees and the number of employees with a formal contract. ${ }^{28}$ This amount is then divided by the total number of employees so that we are measuring the relative size of the informal sector in each municipality (SIZE_INFORMAL). This definition is used because it is consistent with the construction of the GDP in each municipality

\footnotetext{
${ }^{27}$ Ferraz and Finan (2011) calculate this additional variable for only a subset of audited municipalities, dropping the total number of observations down to 331 .

28 This definition of the informal sector includes military and public service employees, accounting for only about 17 percent of informal employment as defined in this paper (IBGE). Results do not change when excluding military and public service employees from the definition. For brevity, these results are not presented in this paper, but are available upon request.
} 
(IBGE). Thus, this part of the informal sector is at least somewhat included in the official GDP estimates.

Recall, the corruption variables represent corruption for the years 2001-2003. Therefore, given that the Census is available for years 2000 and 2010, this paper uses the size of the informal sector in 2000 as the control variable of interest. Thus, making SIZE_INFORMAL a predetermined variable in this model.

This paper includes an additional 19 variables to control for a variety of characteristics at or prior to the year of 2000 that are common in the literature (see, e.g., Higgins et al., 2006; Resende, 2013; Cravo and Resende, 2013). These variables include population and demographic controls (e.g., Resende, 2013), average years of schooling (e.g., Cravo and Resende, 2013), and industrial employment structure (e.g., Higgins et al., 2006). An additional control is included to measure the cost of transport from each municipal headquarters to the city of São Paulo (Resende, 2013). This variable is included as São Paulo is essentially the center of economic activity in Brazil, and therefore is what many municipalities depend on for development.

Lastly, I control for the overall quality of government in each municipality (INSTITUTION). The IBGE provides a broad measure of institutional quality, the Municipal Institutional Quality Indicator (Indicador de Qualidade Institucional Municipal - IQIM), which is used by the Ministry of Planning. This index broadly measures the overall efficiency of municipal governments from 1997-2000. A higher score in the IQIM index represents more efficient municipal governments. Given this, it is likely that this index will be positively related to economic outcomes, and negatively related to both corruption and informal sector size, thus it is important to include this variable in all regressions. All independent variable names, brief descriptions, and sources are given in table 3.3 and table 3.4. 


\subsection{Results}

For brevity, results are presented only for the main variables of interest (PROB_CORRUPT, PROB_CORRUPT_2, MISMANAGE, and SIZE_INFORMAL). Full results are available in Chapter 3, Appendix A. Table 3.5 and table 3.6 present the most basic results, with no additional controls included. Table 3.5 estimates the effect of corruption on GDP per-capita in 2004 and income per-worker in 2000 both with and without controlling for the size of the informal sector. Specifications (1) through (4) include with corruption only, while specifications (5) through (8) include both corruption and the size of the informal sector. Similarly, table $\mathbf{3 . 6}$ estimates these effects for the 2010 period. In both cases, the negative effect of corruption decreases in magnitude once the size of the informal sector is controlled for as expected. Thus, estimates of the effect corruption has on economic outcomes without controlling for the size of the informal economy are likely overstated.

Table 3.5: The effect corruption and the informal economy have on GDP per-capita in 2004 and income per-capita from different sources in 2000; no additional controls included.

\begin{tabular}{|c|c|c|c|c|c|c|c|c|}
\hline & \multicolumn{5}{|c|}{ Types of Income in 2000} & \multicolumn{3}{|c|}{ Types of Income in 2000} \\
\hline & $\begin{array}{c}G D P \_P C \_04 \\
\text { (1) }\end{array}$ & $\begin{array}{l}\text { TOTAL } \\
\text { (2) }\end{array}$ & $\begin{array}{l}\text { FORMAL } \\
\text { (3) }\end{array}$ & $\begin{array}{c}\text { INFORMAL } \\
\text { (4) }\end{array}$ & $\begin{array}{c}G D P \_P C \_04 \\
\text { (5) }\end{array}$ & $\begin{array}{c}\text { TOTAL } \\
\text { (6) }\end{array}$ & $\begin{array}{c}\text { FORMAL } \\
\text { (7) }\end{array}$ & $\begin{array}{c}\text { INFORMAL } \\
(8)\end{array}$ \\
\hline PROB_CORRUPT & $\begin{array}{c}-1.064 * * * \\
(0.410)\end{array}$ & $\begin{array}{c}-0.471 * * \\
(0.192)\end{array}$ & $\begin{array}{c}-0.351 * * \\
(0.162)\end{array}$ & $\begin{array}{c}-0.558 * * * \\
(0.158)\end{array}$ & $\begin{array}{c}-0.860 * * * \\
(0.283)\end{array}$ & $\begin{array}{c}-0.368 * * * \\
(0.128)\end{array}$ & $\begin{array}{c}-0.302 * * \\
(0.138)\end{array}$ & $\begin{array}{c}-0.485 * * * \\
(0.122)\end{array}$ \\
\hline SIZE_INFORMAL & & & & & $\begin{array}{c}-2.447 * * * \\
(0.157) \\
\end{array}$ & $\begin{array}{c}-1.236^{* * *} * \\
(0.066)\end{array}$ & $\begin{array}{c}-0.585 * * * \\
(0.072) \\
\end{array}$ & $\begin{array}{c}-0.872 * * * \\
(0.072)\end{array}$ \\
\hline Observations & 476 & 476 & 476 & 476 & 476 & 476 & 476 & 476 \\
\hline R-squared & 0.020 & 0.019 & 0.013 & 0.030 & 0.369 & 0.445 & 0.138 & 0.271 \\
\hline PROB_CORRUPT_2 & $\begin{array}{c}-4.094 * * * \\
(0.591)\end{array}$ & $\begin{array}{c}-2.013 * * * \\
(0.283)\end{array}$ & $\begin{array}{c}-1.396 * * * \\
(0.268)\end{array}$ & $\begin{array}{c}-1.630 * * * \\
(0.274)\end{array}$ & $\begin{array}{c}-2.373 * * * \\
(0.529)\end{array}$ & $\begin{array}{c}-1.143 * * * \\
(0.237)\end{array}$ & $\begin{array}{c}-1.002 * * * \\
(0.263)\end{array}$ & $\begin{array}{c}-1.021 * * * \\
(0.284)\end{array}$ \\
\hline SIZE_INFORMAL & & & & & $\begin{array}{c}-2.330 * * * \\
(0.152)\end{array}$ & $\begin{array}{c}-1.179 * * * \\
(0.067)\end{array}$ & $\begin{array}{c}-0.534 * * * \\
(0.074)\end{array}$ & $\begin{array}{c}-0.824 * * * \\
(0.074)\end{array}$ \\
\hline Observations & 476 & 476 & 476 & 476 & 476 & 476 & 476 & 476 \\
\hline R-squared & 0.077 & 0.090 & 0.056 & 0.067 & 0.381 & 0.462 & 0.155 & 0.273 \\
\hline
\end{tabular}


Table 3.6: The effect corruption and the informal economy have on GDP per-capita and income per-capita from different sources in 2010; no additional controls included.

\begin{tabular}{|c|c|c|c|c|c|c|c|c|}
\hline & \multicolumn{5}{|c|}{ Types of Income in 2010} & \multicolumn{3}{|c|}{ Types of Income in 2010} \\
\hline & $\begin{array}{c}G D P_{-} P C_{-} 10 \\
(1)\end{array}$ & $\begin{array}{c}\text { TOTAL } \\
\text { (2) }\end{array}$ & $\begin{array}{c}\text { FORMAL } \\
\text { (3) }\end{array}$ & $\begin{array}{c}\text { INFORMAL } \\
\text { (4) }\end{array}$ & $\begin{array}{c}G D P_{-} P C_{-} 10 \\
(5)\end{array}$ & $\begin{array}{c}\text { TOTAL } \\
(6)\end{array}$ & $\begin{array}{c}\text { FORMAL } \\
\text { (7) }\end{array}$ & $\begin{array}{c}\text { INFORMAL } \\
(8)\end{array}$ \\
\hline PROB_CORRUPT & $\begin{array}{c}-0.951 * * \\
(0.397)\end{array}$ & $\begin{array}{c}-0.306 * * \\
(0.155)\end{array}$ & $\begin{array}{c}-0.276^{* *} \\
(0.108)\end{array}$ & $\begin{array}{l}-0.528^{*} \\
(0.271)\end{array}$ & $\begin{array}{c}-0.760 * * * \\
(0.283)\end{array}$ & $\begin{array}{c}-0.224 * * \\
(0.109)\end{array}$ & $\begin{array}{c}-0.236 * * * \\
(0.087)\end{array}$ & $\begin{array}{c}-0.452^{* *} \\
(0.227)\end{array}$ \\
\hline SIZE_INFORMAL & & & & & $\begin{array}{c}-2.288 * * * \\
(0.150)\end{array}$ & $\begin{array}{c}-0.973 * * * \\
(0.049)\end{array}$ & $\begin{array}{c}-0.484 * * * \\
(0.045)\end{array}$ & $\begin{array}{c}-0.909 * * * \\
(0.099)\end{array}$ \\
\hline Observations & 476 & 476 & 476 & 476 & 476 & 476 & 476 & 476 \\
\hline R-squared & 0.018 & 0.013 & 0.019 & 0.015 & 0.372 & 0.442 & 0.217 & 0.169 \\
\hline PROB_CORRUPT_2 & $\begin{array}{c}-3.778 * * * \\
(0.526)\end{array}$ & $\begin{array}{c}-1.415 * * * \\
(0.192)\end{array}$ & $\begin{array}{c}-0.801 * * * \\
(0.144)\end{array}$ & $\begin{array}{c}-1.711 * * * \\
(0.320)\end{array}$ & $\begin{array}{c}-2.167 * * * \\
(0.472)\end{array}$ & $\begin{array}{c}-0.724 * * * \\
(0.158)\end{array}$ & $\begin{array}{c}-0.459 * * * \\
(0.143)\end{array}$ & $\begin{array}{c}-1.077 * * * \\
(0.338)\end{array}$ \\
\hline SIZE_INFORMAL & & & & & $\begin{array}{c}-2.181 * * * \\
(0.146)\end{array}$ & $\begin{array}{c}-0.936 * * * \\
(0.050)\end{array}$ & $\begin{array}{c}-0.463^{* * *} * \\
(0.046)\end{array}$ & $\begin{array}{c}-0.858 * * * \\
(0.102)\end{array}$ \\
\hline Observations & 476 & 476 & 476 & 476 & 476 & 476 & 476 & 476 \\
\hline R-squared & 0.076 & 0.072 & 0.043 & 0.043 & 0.384 & 0.453 & 0.216 & 0.174 \\
\hline
\end{tabular}

Table 3.7 and table 3.8 present the results for the first time period of interest, GDP percapita in 2004 and income per-worker in 2000 using PROB_CORRUPT (table 3.7) and PROB_CORRUPT_2 (table 3.8) as the measure of corruption. Basic controls are included in each specification. As can be seen in these two tables, while the effect of corruption is negative in a majority of the specifications, it is generally statistically insignificant. Only in the case where corruption is measured by PROB_CORRUPT does corruption seem to have a negative and statistically significant association with GDP per-capita. However, this result is not robust to the inclusion of state fixed effects. Importantly, the F-Statistic indicates that these state effects are consistently different from zero. This fits in line with the story that corruption is a product of its environment (Svensson, 2005), as the negative effect found in regressions without state effects may be drive by the (unobserved) cultural environment of the area. Furthermore, it appears that the inclusion of less blatant forms of corruption (MISMANAGE) has very little impact on the results. Furthermore, MISMANAGE is never statistically significant. 
Table 3.7: The effect corruption, measured by the share of resources (R\$) found to involve corruption, and the informal economy have on GDP per-capita in 2004 and income per-capita from different sources in 2000.

\begin{tabular}{|c|c|c|c|c|c|c|c|c|}
\hline & \multicolumn{5}{|c|}{ Types of Income in 2000} & \multicolumn{3}{|c|}{ Types of Income in 2000} \\
\hline & $\begin{array}{c}G D P \_P C \_04 \\
(1)\end{array}$ & $\begin{array}{l}\text { TOTAL } \\
\text { (2) }\end{array}$ & $\begin{array}{c}\text { FORMAL } \\
\text { (3) }\end{array}$ & $\begin{array}{c}\text { INFORMAL } \\
\text { (4) }\end{array}$ & $\begin{array}{c}G D P_{-} P C_{-} 04 \\
(5)\end{array}$ & $\begin{array}{l}\text { TOTAL } \\
\text { (6) }\end{array}$ & $\begin{array}{c}\text { FORMAL } \\
\text { (7) }\end{array}$ & $\begin{array}{c}\text { INFORMAL } \\
(8)\end{array}$ \\
\hline \multirow{2}{*}{ PROB_CORRUPT } & $-0.417 *$ & -0.044 & -0.051 & $-0.186^{*}$ & $\begin{array}{l}-0.343 \\
\end{array}$ & 0.013 & -0.029 & -0.122 \\
\hline & $(0.219)$ & $(0.079)$ & $(0.089)$ & $(0.106)$ & $(0.241)$ & $(0.074)$ & $(0.084)$ & $(0.112)$ \\
\hline \multirow[t]{2}{*}{ SIZE_INFORMAL } & $-0.894 * * *$ & $-0.391 * * *$ & $0.228 * *$ & 0.008 & $-0.695 * * *$ & $-0.438 * * *$ & $0.280 * *$ & -0.141 \\
\hline & $(0.202)$ & $(0.078)$ & $(0.108)$ & $(0.105)$ & $(0.263)$ & $(0.080)$ & $(0.110)$ & $(0.124)$ \\
\hline Observations & 434 & 434 & 434 & 434 & 434 & 434 & 434 & 434 \\
\hline R-squared & 0.642 & 0.807 & 0.503 & 0.626 & 0.687 & 0.852 & 0.623 & 0.702 \\
\hline State Fixed Effects? & No & No & No & No & Yes & Yes & Yes & Yes \\
\hline Lottery Fixed Effects? & No & No & No & No & Yes & Yes & Yes & Yes \\
\hline F-Stat State Effects & - & - & - & - & $2.670 * * *$ & $6.170 * * *$ & $6.520 * * *$ & $4.500 * * *$ \\
\hline \multirow[t]{2}{*}{ PROB_CORRUPT } & $-0.463^{*}$ & -0.106 & -0.100 & $-0.225^{*}$ & -0.482 & 0.013 & -0.070 & -0.065 \\
\hline & $(0.252)$ & $(0.096)$ & $(0.108)$ & $(0.129)$ & $(0.304)$ & $(0.091)$ & $(0.107)$ & $(0.131)$ \\
\hline \multirow[t]{2}{*}{ MISMANAGE } & 0.070 & 0.000 & 0.002 & -0.006 & 0.044 & 0.002 & 0.003 & -0.005 \\
\hline & $(0.044)$ & $(0.008)$ & $(0.012)$ & $(0.010)$ & $(0.050)$ & $(0.010)$ & $(0.013)$ & $(0.012)$ \\
\hline \multirow[t]{2}{*}{ SIZE_INFORMAL } & $-0.826 * * *$ & $-0.430 * * *$ & 0.167 & 0.020 & -0.442 & $-0.438 * * *$ & $0.294 * *$ & -0.138 \\
\hline & $(0.234)$ & $(0.099)$ & $(0.131)$ & $(0.136)$ & $(0.290)$ & $(0.105)$ & $(0.131)$ & $(0.161)$ \\
\hline Observations & 331 & 331 & 331 & 331 & 331 & 331 & 331 & 331 \\
\hline R-squared & 0.662 & 0.800 & 0.505 & 0.619 & 0.705 & 0.848 & 0.630 & 0.704 \\
\hline State Fixed Effects? & No & No & No & No & Yes & Yes & Yes & Yes \\
\hline Lottery Fixed Effects? & No & No & No & No & Yes & Yes & Yes & Yes \\
\hline F-Stat State Effects & - & - & - & - & $2.080 * * *$ & $3.960 * * *$ & $5.140 * * *$ & $3.660 * * *$ \\
\hline
\end{tabular}

Table 3.8: The effect corruption, measured by the share of items found to involve corruption, and the informal economy have on GDP per-capita and income per-capita from different sources in 2000.

\begin{tabular}{|c|c|c|c|c|c|c|c|c|}
\hline & \multicolumn{5}{|c|}{ Types of Income in 2000} & \multicolumn{3}{|c|}{ Types of Income in 2000} \\
\hline & $\begin{array}{c}G D P \_P C \_04 \\
(1)\end{array}$ & $\begin{array}{c}\text { TOTAL } \\
\text { (2) }\end{array}$ & $\begin{array}{c}\text { FORMAL } \\
\text { (3) }\end{array}$ & $\begin{array}{c}\text { INFORMAL } \\
(4)\end{array}$ & $\begin{array}{c}G D P_{-} P C_{-} 04 \\
(5)\end{array}$ & $\begin{array}{c}\text { TOTAL } \\
\text { (6) }\end{array}$ & $\begin{array}{c}\text { FORMAL } \\
(7)\end{array}$ & $\begin{array}{c}\text { INFORMAL } \\
(8)\end{array}$ \\
\hline \multirow[t]{2}{*}{ PROB_CORRUPT_2 } & 0.130 & -0.181 & -0.240 & -0.193 & 0.118 & -0.087 & -0.237 & -0.001 \\
\hline & $(0.474)$ & $(0.182)$ & $(0.229)$ & $(0.246)$ & $(0.499)$ & $(0.208)$ & $(0.239)$ & $(0.270)$ \\
\hline \multirow[t]{2}{*}{ SIZE_INFORMAL } & $-0.868 * * *$ & $-0.391 * * *$ & $0.227 * *$ & 0.016 & $-0.679 * *$ & $-0.441 * * *$ & $0.275^{* *}$ & -0.136 \\
\hline & $(0.201)$ & $(0.078)$ & $(0.108)$ & $(0.105)$ & $(0.263)$ & $(0.080)$ & $(0.110)$ & $(0.124)$ \\
\hline Observations & 434 & 434 & 434 & 434 & 434 & 434 & 434 & 434 \\
\hline R-squared & 0.639 & 0.807 & 0.505 & 0.624 & 0.686 & 0.852 & 0.624 & 0.701 \\
\hline State Fixed Effects? & No & No & No & No & Yes & Yes & Yes & Yes \\
\hline Lottery Fixed Effects? & No & No & No & No & Yes & Yes & Yes & Yes \\
\hline F-Stat State Effects & - & - & - & - & $2.700 * * *$ & $5.970 * * *$ & $6.480 * * *$ & $4.410 * * *$ \\
\hline \multirow[t]{2}{*}{ PROB_CORRUPT_2 } & -0.067 & -0.236 & -0.357 & 0.026 & 0.359 & -0.010 & -0.254 & 0.242 \\
\hline & $(0.678)$ & $(0.263)$ & $(0.325)$ & $(0.343)$ & $(0.718)$ & $(0.262)$ & $(0.331)$ & $(0.327)$ \\
\hline \multirow[t]{2}{*}{ MISMANAGE } & 0.067 & 0.004 & 0.008 & -0.009 & 0.034 & 0.002 & 0.006 & -0.009 \\
\hline & $(0.049)$ & $(0.009)$ & $(0.013)$ & $(0.011)$ & $(0.054)$ & $(0.009)$ & $(0.014)$ & $(0.012)$ \\
\hline \multirow[t]{2}{*}{ SIZE_INFORMAL } & $-0.801 * * *$ & $-0.432 * * *$ & 0.159 & 0.034 & -0.403 & $-0.440 * * *$ & $0.285^{* *}$ & -0.123 \\
\hline & $(0.232)$ & $(0.100)$ & $(0.133)$ & $(0.139)$ & $(0.287)$ & $(0.107)$ & $(0.133)$ & $(0.164)$ \\
\hline Observations & 331 & 331 & 331 & 331 & 331 & 331 & 331 & 331 \\
\hline R-squared & 0.659 & 0.800 & 0.506 & 0.615 & 0.702 & 0.848 & 0.630 & 0.704 \\
\hline State Fixed Effects? & No & No & No & No & Yes & Yes & Yes & Yes \\
\hline Lottery Fixed Effects? & No & No & No & No & Yes & Yes & Yes & Yes \\
\hline F-Stat State Effects & - & - & - & - & $2.200 * * *$ & $3.680 * * *$ & $4.970 * * *$ & $3.720 * * *$ \\
\hline
\end{tabular}


However, the size of the informal sector (SIZE_INFORMAL) has a fairly robust, negative and statistically significant relationship with both GDP per-capita and total income per-worker. This is especially interesting since SIZE_INFORMAL also seems to have a positive relationship with formal income per-worker. Given its negative relationship with total income, this is suggesting that even if SIZE_INFORMAL results in positive spillovers to the formal sector, it has a negative overall impact on incomes.

In addition, the effects of SIZE_INFORMAL on GDP per-capita are large in magnitude. Considering only the statistically significant effects, a one standard deviation increase in the size of the informal sector (0.186) is associated with a decrease in GDP per-capita of a maximum of about 17 percent to a minimum of about 13 percent, depending on the specification. ${ }^{29}$ The effects of the informal sector on total income levels are smaller in magnitude than their effects on GDP per-capita, however the size of the effects are relatively stable across all specifications. A one standard deviation increase in the size of the informal sector $(0.186)$ is associated with a decrease in income per-worker of a maximum of about 8 percent to a minimum of about 7 percent.

This negative relationship, however, could be picking up the fact that as GDP falls, informal employment acts as a safety net in the short run even if its effects are negative in the long run therefore causing the share of informal employment to rise (Loayza and Rigolini, 2011). However, since we are looking at the effect the size of the informal sector in 2000 has on GDP per-capita in 2004, it is unlikely that this effect is exclusively picking up the business cycle effect. However, these results will be checked for robustness looking at the effect the size of the informal sector has on GDP per-capita after 10 years as well.

\footnotetext{
${ }^{29}$ Standard deviation increases come from summary statistics provided in table $\mathbf{3 . 2}$.
} 
A similar story emerges when looking at the results from the second time period of interest, GDP per-capita in 2010 and income levels in 2010, presented in table 3.9 and table

3.10.

\begin{tabular}{|c|c|c|c|c|c|c|c|c|}
\hline & \multicolumn{5}{|c|}{ Types of Income in 2010} & \multicolumn{3}{|c|}{ Types of Income in 2010} \\
\hline & $\begin{array}{c}G D P_{-} P C_{-} 10 \\
(1)\end{array}$ & $\begin{array}{l}\text { TOTAL } \\
\text { (2) }\end{array}$ & $\begin{array}{c}\text { FORMAL } \\
\text { (3) }\end{array}$ & $\begin{array}{c}\text { INFORMAL } \\
\text { (4) }\end{array}$ & $\underset{(5)}{G D P_{-} P C_{-} 10}$ & $\begin{array}{l}\text { TOTAL } \\
\text { (6) }\end{array}$ & $\begin{array}{c}\text { FORMAL } \\
\text { (7) }\end{array}$ & $\begin{array}{c}\text { INFORMAL } \\
\text { (8) }\end{array}$ \\
\hline PROB_CORRUPT & $\begin{array}{c}-0.456 * * \\
(0.203)\end{array}$ & $\begin{array}{c}0.010 \\
(0.054)\end{array}$ & $\begin{array}{c}-0.063 \\
(0.069)\end{array}$ & $\begin{array}{l}-0.037 \\
(0.149)\end{array}$ & $\begin{array}{l}-0.299 \\
(0.207)\end{array}$ & $\begin{array}{c}-0.002 \\
(0.051)\end{array}$ & $\begin{array}{l}-0.085 \\
(0.065)\end{array}$ & $\begin{array}{c}0.133 \\
(0.104)\end{array}$ \\
\hline SIZE_INFORMAL & $\begin{array}{c}-0.795 * * * \\
(0.199)\end{array}$ & $\begin{array}{c}-0.318 * * * \\
(0.061)\end{array}$ & $\begin{array}{l}-0.028 \\
(0.070)\end{array}$ & $\begin{array}{l}-0.084 \\
(0.130)\end{array}$ & $\begin{array}{c}-0.609 * * \\
(0.255)\end{array}$ & $\begin{array}{c}-0.260 * * * \\
(0.065)\end{array}$ & $\begin{array}{c}0.095 \\
(0.074)\end{array}$ & $\begin{array}{c}-0.251 * * \\
(0.124)\end{array}$ \\
\hline Observations & 434 & 434 & 434 & 434 & 434 & 434 & 434 & 434 \\
\hline $\mathrm{R}$-squared & 0.628 & 0.803 & 0.522 & 0.555 & 0.681 & 0.855 & 0.633 & 0.802 \\
\hline State Fixed Effects? & No & No & No & No & Yes & Yes & Yes & Yes \\
\hline Lottery Fixed Effects? & No & No & No & No & Yes & Yes & Yes & Yes \\
\hline F-Stat State Effects & - & - & - & - & $4.310 * * *$ & $5.150 * * *$ & $5.050 * * *$ & $25.570^{* * *}$ \\
\hline PROB_CORRUPT & $\begin{array}{l}-0.425^{*} \\
(0.220)\end{array}$ & $\begin{array}{l}-0.017 \\
(0.063)\end{array}$ & $\begin{array}{l}-0.100 \\
(0.080)\end{array}$ & $\begin{array}{l}-0.119 \\
(0.167)\end{array}$ & $\begin{array}{l}-0.313 \\
(0.254)\end{array}$ & $\begin{array}{l}-0.013 \\
(0.058)\end{array}$ & $\begin{array}{l}-0.129 * \\
(0.077)\end{array}$ & $\begin{array}{c}0.228 \\
(0.142)\end{array}$ \\
\hline MISMANAGE & $\begin{array}{c}0.052 \\
(0.035)\end{array}$ & $\begin{array}{l}-0.001 \\
(0.006)\end{array}$ & $\begin{array}{l}0.014 * \\
(0.007)\end{array}$ & $\begin{array}{c}-0.044 * * * \\
(0.014)\end{array}$ & $\begin{array}{c}0.027 \\
(0.038)\end{array}$ & $\begin{array}{c}0.005 \\
(0.008)\end{array}$ & $\begin{array}{c}0.024 * * * \\
(0.008)\end{array}$ & $\begin{array}{c}-0.026^{*} \\
(0.014)\end{array}$ \\
\hline SIZE_INFORMAL & $\begin{array}{c}-0.761 * * * \\
(0.226)\end{array}$ & $\begin{array}{c}-0.374 * * * \\
(0.072)\end{array}$ & $\begin{array}{c}-0.094 \\
(0.085)\end{array}$ & $\begin{array}{c}0.019 \\
(0.148) \\
\end{array}$ & $\begin{array}{c}-0.380 \\
(0.274) \\
\end{array}$ & $\begin{array}{c}-0.259 * * * \\
(0.080)\end{array}$ & $\begin{array}{c}0.084 \\
(0.091)\end{array}$ & $\begin{array}{l}-0.176 \\
(0.134)\end{array}$ \\
\hline Observations & 331 & 331 & 331 & 331 & 331 & 331 & 331 & 331 \\
\hline R-squared & 0.668 & 0.800 & 0.512 & 0.557 & 0.717 & 0.857 & 0.653 & 0.806 \\
\hline State Fixed Effects? & No & No & No & No & Yes & Yes & Yes & Yes \\
\hline Lottery Fixed Effects? & No & No & No & No & Yes & Yes & Yes & Yes \\
\hline F-Stat State Effects & - & - & - & - & $3.980 * * *$ & $5.140 * * *$ & $4.560 * * *$ & $20.850 * * *$ \\
\hline
\end{tabular}

The measures of corruption, PROB_CORRUPT and PROB_CORRUPT_2 have little relationship to GDP per-capita and income per-worker. As before, PROB_CORRUPT has a negative relationship with GDP per-capita that is not robust to the inclusion of state and lottery fixed effects. The major difference between the first time period and the time period given in tables 3.9 and 3.10 is that now when MISMANAGE and state and lottery fixed effects are included, PROB_CORRUPT_2 actually has a positive association with income. Since PROP_CORRUPT_2 measures the frequency of corrupt transactions, this could be indicating that a "grease the wheels" situation is present (e.g., Leff, 1964; Huntington, 1968; Heckelman 
and Powell, 2010). In this case a higher frequency of corrupt transactions leads to higher income

levels. However this effect is only positive and statistically significant in two of the 16

specifications using PROB_CORRUPT_2 in table 3.10.

\begin{tabular}{|c|c|c|c|c|c|c|c|c|}
\hline & \multicolumn{5}{|c|}{ Types of Income in 2010} & \multicolumn{3}{|c|}{ Types of Income in 2010} \\
\hline & $\begin{array}{c}G D P_{-} P C_{-} 10 \\
(1)\end{array}$ & $\begin{array}{c}\text { TOTAL } \\
(2) \\
\end{array}$ & $\begin{array}{c}\text { FORMAL } \\
\text { (3) }\end{array}$ & $\begin{array}{c}\text { INFORMAL } \\
(4) \\
\end{array}$ & $\begin{array}{c}G D P_{-} P C_{-} 10 \\
(5)\end{array}$ & $\begin{array}{c}\text { TOTAL } \\
(6) \\
\end{array}$ & $\begin{array}{c}\text { FORMAL } \\
(7)\end{array}$ & $\begin{array}{c}\text { INFORMAL } \\
(8) \\
\end{array}$ \\
\hline \multirow[t]{2}{*}{ PROB_CORRUPT_2 } & 0.042 & 0.144 & 0.137 & -0.138 & 0.263 & $0.259 * *$ & $0.243^{*}$ & 0.364 \\
\hline & $(0.394)$ & $(0.123)$ & $(0.130)$ & $(0.270)$ & $(0.424)$ & $(0.119)$ & $(0.144)$ & $(0.223)$ \\
\hline \multirow[t]{2}{*}{ SIZE_INFORMAL } & $-0.769 * * *$ & $-0.316 * * *$ & -0.022 & -0.084 & $-0.590 * *$ & $-0.253 * * *$ & 0.105 & $-0.247 * *$ \\
\hline & $(0.197)$ & $(0.060)$ & $(0.069)$ & $(0.131)$ & $(0.254)$ & $(0.064)$ & $(0.074)$ & $(0.124)$ \\
\hline Observations & 434 & 434 & 434 & 434 & 434 & 434 & 434 & 434 \\
\hline R-squared & 0.624 & 0.804 & 0.522 & 0.555 & 0.680 & 0.856 & 0.634 & 0.802 \\
\hline State Fixed Effects? & No & No & No & No & Yes & Yes & Yes & Yes \\
\hline Lottery Fixed Effects? & No & No & No & No & Yes & Yes & Yes & Yes \\
\hline F-Stat State Effects & - & - & - & - & $4.510 * * *$ & $5.370 * * *$ & $5.070 * * *$ & $25.490 * * *$ \\
\hline \multirow[t]{2}{*}{ PROB_CORRUPT_2 } & 0.047 & 0.186 & 0.125 & 0.169 & 0.627 & $0.332 * *$ & 0.172 & $0.671 * *$ \\
\hline & $(0.587)$ & $(0.184)$ & $(0.205)$ & $(0.341)$ & $(0.599)$ & $(0.164)$ & $(0.191)$ & $(0.318)$ \\
\hline \multirow[t]{2}{*}{ MISMANAGE } & 0.048 & -0.005 & 0.010 & $-0.048 * * *$ & 0.014 & -0.000 & $0.020 * *$ & $-0.035^{* *}$ \\
\hline & $(0.040)$ & $(0.007)$ & $(0.008)$ & $(0.015)$ & $(0.043)$ & $(0.008)$ & $(0.009)$ & $(0.015)$ \\
\hline \multirow[t]{2}{*}{ SIZE_INFORMAL } & $-0.734 * * *$ & $-0.366 * * *$ & -0.083 & 0.032 & -0.335 & $-0.242 * * *$ & 0.098 & -0.153 \\
\hline & $(0.225)$ & $(0.073)$ & $(0.086)$ & $(0.150)$ & $(0.272)$ & $(0.080)$ & $(0.091)$ & $(0.133)$ \\
\hline Observations & 331 & 331 & 331 & 331 & 331 & 331 & 331 & 331 \\
\hline R-squared & 0.664 & 0.801 & 0.511 & 0.557 & 0.717 & 0.857 & 0.653 & 0.806 \\
\hline State Fixed Effects? & No & No & No & No & Yes & Yes & Yes & Yes \\
\hline Lottery Fixed Effects? & No & No & No & No & Yes & Yes & Yes & Yes \\
\hline F-Stat State Effects & - & - & - & - & $5.010 * * *$ & $5.370 * * *$ & $4.620 * * *$ & $21.110 * * *$ \\
\hline
\end{tabular}

Notes: $* * *$ indicates statistically significant at $1 \%$ level, ** indicates statistically significant at 5\% level, * indicates statistically significant at $10 \%$ level. Standard errors are in parentheses. Basic controls and constant included in all regressions.

Another major difference between the first period and the period presented in table 3.9

and 3.10 is that MISMANAGE seems to have more of an impact in the longer run. Municipalities that experience a significant amount of minor misconduct (MISMANAGE), also experience a high frequency of corrupt acts (PROB_CORRUPT_2). However, these corrupt acts seem to be less severe. ${ }^{30}$ Since these minor acts of misconduct represent less obvious inefficiencies, it is less likely that voters will discover these acts and punish politicians for engaging in them (Ferraz and

${ }^{30}$ Correlate between PROB_CORRUPT_2 and MISMANAGE is 0.433 , while the correlation between PROB_CORRUPT and MISMANAGE is only 0.114. 
Finan, 2011). Given this, an increase in MISMANAGE, holding corruption constant, may be associated with inefficient politicians holding office for an extended period of time. It seems that MISMANAGE has a statistically significant positive effect on formal income per-worker and a statistically significant negative effect on informal income per-worker. This is possibly indicating that these minor acts of misconduct tend to benefit the formal sector at the expense of the informal sector. ${ }^{31}$ However, MISMANAGE still has no statistically significant relationship to total income per-worker or GDP per-capita in any case.

However, just as in table 3.7 and table 3.8, the size of the informal sector (SIZE_INFORMAL) exhibits a negative and statistically significant relationship to both GDP percapita and total income levels, although this effect is slightly smaller in magnitude. Thus, across both time periods, the size of the informal sector has a negative relationship with both GDP percapita and total income levels. ${ }^{32}$ This is robust to the inclusion of a variety of different corruption measures, as well as state and lottery fixed effects. ${ }^{33}$ It is possible, however, that the results are still suffering from omitted variable bias as some unobserved factor may be influencing both the size of the informal sector as well as GDP and income levels. Therefore, these results will be supplemented with an instrumental variable analysis.

\footnotetext{
${ }^{31}$ This fits with the examples of mismanagement given in Ferraz and Finan (2011). A common example of mismanagement they cite is when less than three firms bid for a public contract, despite the Brazilian law stating that at least three firms have to bid. MISMANAGE in this case seems to only benefit the formal sector. ${ }^{32}$ Given that a majority (over $75 \%$ ) of the municipalities experienced at least one instance of corruption, it is unlikely that the lack of significant effects are driven by a skewed distribution due to a large number of zeros. Results are presented in Chapter 3, Appendix B tables 3.B1 and 3.B2 using two subsamples of data based on the municipalities' PROB_CORRUPT score: one sample coming from municipalities experiencing corruption above the median and another sample coming from municipalities experiencing corruption below or equal to the median. As shown in the tables, the statistically significant results found between income and corruption seem to be driven by municipalities experiencing corruption above the median level. As with the main results, these few statistically significant results indicate that corruption has a negative effect.

${ }^{33}$ Municipalities may learn how to hide their corrupt acts better as time progresses, potentially driving the insignificant effect of corruption on GDP and income levels. To test for this I interact each lottery dummy with PROB_CORRUPT, allowing for a potentially more precise measure of corruption. As shown in Chapter 3, Appendix B table 3.B3, the marginal effect of corruption is generally insignificant even with these interactions, matching the main results with state and lottery fixed effects.
} 
A significant portion of informal employment in general fluctuates seasonally (Hussmanns, 2004). More specifically, a lot of the informal employment that fluctuates seasonally is a result of tourism employment (Cukier and Wall, 1994). Furthermore, as argued in Loayza and Rigolini (2011) informal employment in the agricultural sector specifically may be more vulnerable to weather shocks than formal agriculture. Given that the agricultural industry alone makes up over a quarter of informal employment and that much of the non-agricultural informal employment is likely to fluctuate seasonally, it is likely that the size of the informal sector is going to be impacted by weather patterns in each municipality. Therefore, it seems reasonable to expect that the size of the informal sector is going to be dependent upon rainfall and temperature patterns during the summer months, Brazil's peak tourism period (December February).

IPEADATA provides quarterly measurements of both rainfall and temperature patterns across each municipality averaged over a thirty year period. This data is summarizing the weather patterns that were present in the municipalities for each season from $1961-1990$. This paper uses the summer period specifically as this is the peak period for tourism in Brazil and is part of the agricultural growing season. Thus, municipalities with climates more suitable to agricultural and attractive to tourists may be more likely to experience a large amount of informal employment.

Furthermore, it is reasonable to assume that average weather patterns from 1961 to 1990 are otherwise unrelated to GDP per-capita and total income levels. As described in Loayza and Rigolini (2011) the formal economy is less vulnerable to changes in weather patterns than the informal sector as the formal economy often has better access to technology. Thus, while historical rain and temperature patterns may impact the size of the informal sector by creating an 
industrial environment comprised of (informal) firms in the agricultural and tourism sectors, they

likely have no direct impact on current GDP per-capita and income levels.

\begin{tabular}{|c|c|c|c|c|c|c|c|c|}
\hline & GDP_PC_04 & TOTAL_OO & GDP_PC_04 & TOTAL_OO & $G D P \_P C_{-} 10$ & TOTAL_10 & GDP_PC_10 & TOTAL_10 \\
\hline PROB_CORRUPT & $\begin{array}{l}-0.388^{*} \\
(0.200)\end{array}$ & $\begin{array}{c}0.042 \\
(0.092)\end{array}$ & & & $\begin{array}{c}-0.426 * * \\
(0.197)\end{array}$ & $\begin{array}{c}0.058 \\
(0.063)\end{array}$ & & \\
\hline PROB_CORRUPT_2 & & & 0.044 & -0.064 & & & -0.114 & 0.183 \\
\hline SIZE_INFORMAL & $-1.556 * * *$ & 0.269 & $\begin{array}{c}(0.500) \\
-1.583 * * *\end{array}$ & $\begin{array}{c}(0.213) \\
0.277\end{array}$ & $-1.163 * *$ & -0.019 & $\begin{array}{c}(0.414) \\
-1.176 * *\end{array}$ & $\begin{array}{l}(0.137) \\
-0.035\end{array}$ \\
\hline & $(0.550)$ & $(0.246)$ & $(0.548)$ & $(0.245)$ & $(0.522)$ & $(0.191)$ & $(0.519)$ & $(0.189)$ \\
\hline Observations & 404 & 404 & 404 & 404 & 404 & 404 & 404 & 404 \\
\hline R-squared & 0.646 & 0.768 & 0.643 & 0.767 & 0.641 & 0.791 & 0.638 & 0.793 \\
\hline J-Statistic & 0.927 & 0.716 & 1.053 & 0.626 & 0.849 & 1.194 & 0.933 & 1.374 \\
\hline F-Statistic & $22.486 * * *$ & 22.486 *** & $22.427 * * *$ & $22.427 * * *$ & $22.486 * * *$ & $22.486 * * *$ & $22.427 * * *$ & $22.427 * * *$ \\
\hline
\end{tabular}

As can be seen in table 3.11 in all cases the first stage F-statistics always reject the weak instrument null hypothesis according to the Stock and Yogo (2005) critical values and the Jstatistics indicate no evidence to reject the exogeneity of the instruments. Furthermore, the effect of SIZE_INFORMAL on GDP per-capita remains negative and statistically significant in every specification. However, the negative and statistically significant effect of SIZE_INFORMAL on total income per-worker disappears. In addition, PROB_CORRUPT still has a negative and statistically significant impact on GDP per-capita in both periods.

Thus, it appears that the size of the informal sector is negatively related to officially calculated GDP per-capita. This effect is robust to the inclusion of alternative corruption measures, a measurement of nonvisible corruption, and various fixed effects, as well as an instrumental variable analysis. Although this affect may be partially attributed to the fact that officially calculated GDP imperfectly includes the value added from the informal sector, the fact that the size of the informal sector also seems to be negatively related to total income per-worker 
leads to the conclusion that a larger informal sector leads to lower levels of actual output and incomes.

\subsection{Conclusion}

The negative association between average income levels and corruption is well documented. In addition, although the literature is mixed as to the exact direction of the relationship, the idea that corruption and the informal economy are highly connected is widely accepted as well. In particular, a common argument is that the informal economy and corruption are complementary to each other and therefore a higher amount of corruption will be associated with a larger informal economy. Moreover, a larger informal economy is also associated with lower levels of incomes. If this is the case, then it is plausible that the negative association documented between corruption and income levels may be partly due to the effect corruption has on the informal economy.

However, the empirical literature analyzing the links between corruption and income levels almost entirely ignores the effect of the informal economy. This paper exploits a unique data set on corruption and informal sector employment in 476 Brazilian municipalities to estimate whether corruption impacts GDP or income levels once variation in informal economic activity is taken into account. Overall, I find that both corruption and the informal economy are generally associated with poor economic outcomes. However, only the size of the informal economy has a robust statistically significant effect.

In this paper, informal sector size is measured as the share of employees without a formal contract. Thus, a negative association between this measure and output intuitively means that having a larger share of employees working in the informal sector will lower overall output. This 
is likely because production in the informal sector is labor intensive, and therefore less productive than the capital intensive formal sector counterparts.

Importantly, the negative association between informal sector size and output is large in magnitude. For example, one standard deviation increase (0.186) in the share of total employees that are informally employed is associated with a decrease in GDP per-capita of a maximum of about 17 percent to a minimum of about 13 percent, depending on the specification. Further, a one standard deviation increase in the size of the informal sector is associated with a decrease in income (both formal and informal) per-worker of a maximum of about 8 percent to a minimum of about 7 percent. Given that the size of the informal economy varies from a minimum of about 13 percent to a maximum of 98 percent of total employees across municipalities in Brazil, these effects can be extremely large. Thus, the results indicate that the size of the informal economy may be more important for economic outcomes than corruption. 


\section{Chapter 4}

\section{Executive Influence over Reported Corruption Convictions: Are Conviction Rates a Biased Measure of State Level Corruption?}

\subsection{Introduction}

The idea that corruption has a major impact on development is not new. Numerous researchers have empirically estimated the relationship between corruption and economic outcomes using data both from across countries and within (e.g., Mauro, 1995; Mo, 2001; Svensson, 2003). While much of the research focuses on developing countries, where corruption is more prevalent, a subset looks at these relationships in the developed world. ${ }^{34}$ In particular, there are a number of studies that use the US states as the unit of analysis (e.g., Goel and Nelson, 1998; Glaeser and Saks, 2006; Leeson and Sobel, 2008; Alt and Lassen, 2008; Johnson et al., 2011).

Most US state level studies use data on federal corruption convictions from reports by the US Department of Justice's (DOJ) Public Integrity Section (PIN) to measure corruption. This is the only freely available corruption measure for the US that varies both across states and time. However, this data may be problematic for two reasons. First, research has shown that the presidentially appointed federal prosecutors handling a majority of corruption cases tend to make decisions on which cases to take to court based on partisan ties (Gordon, 2009), resulting in a bias of corruption convictions. Second, few studies that using PIN data acknowledge that it is derived from a survey of US Attorneys, not administrative records (Boylan and Long, 2003;

\footnotetext{
${ }^{34}$ See Olken and Pande (2012) for a review of the literature exploring the relationships between corruption and economic outcomes in the developing world.
} 
Cordis and Milyo, 2016), making it relatively easy for attorneys to alter the data in a manner that is politically beneficial. ${ }^{35}$ Therefore, it is possible that the PIN data is politically biased.

Further, even if it is reasonable to assume that the PIN data is unbiased and represents true corruption, ignoring political factors can result in biased conclusions. More specifically, a politically important state, where the stakes are higher for politicians, may experience more corruption. Here, a state's political importance is defined as its importance to win in a presidential election. ${ }^{36}$ In these states, we may see that politicians are more willing to cross the line as the benefits of doing so are higher. If political importance is correlated with key economic outcomes, such as income, growth, or entrepreneurial activity, then empirical results may be biased. The goal of this paper is to show that corruption convictions systematically differ across states due to political factors. These political factors may include biased federal prosecutors, an increase in true corruption stemming from political importance, or both.

The DOJ is a part of the executive branch of government and handles $94 \%$ of all corruption cases in its 94 District Attorney offices across the US (Cordis and Milyo, 2016). Each US Attorney handling these federal corruption cases is appointed by the president and typically serves a four year term. The US Attorneys are also subject to removal by the president. While within administration dismissals are quite rare (Scott, 2007), US Attorneys are commonly replaced when the administration changes power even if their term has not yet expired. When within administration dismissals do occur, it is thought to be for political reasons. For example, the suspected reason behind the dismissal of US Attorneys during the Republican Bush Administration is that these attorneys prosecuted certain high profile Republicans and failed to

\footnotetext{
${ }^{35}$ The terms US Attorney, federal prosecutors, and prosecutors are used interchangeably throughout the paper.

${ }^{36}$ Political importance will be explained in detail in the data section of the paper.
} 
prosecute certain high profile Democrats (Goldstein and Eggen, 2007; Lipton 2007a; Lipton, 2007b; Gordon, 2009; Gordon and Huber, 2009). Given this threat of dismissal, it is unsurprising that these federal prosecutors are susceptible to political influence.

Presidential influence may come in two forms. First, as mentioned above, federal prosecutors may be pressured to prosecute more political opponents than allies. Thus, states may have more corruption convictions when they have more political opponents. However, since a majority of corruption cases do not involve partisan identifiable defendants this effect is likely small. ${ }^{37}$ Second, the presidential administration may attempt to alter overall corruption convictions across states in a way that helps their party's outlook in future elections. This type of presidential influence is the focus of this paper as it is broader and likely more meaningful. More specifically, with this idea of presidential influence in mind, this paper explores how each state's level of political importance in a presidential election influences reported corruption convictions.

Corruption convictions may vary based on the state's political importance for (at least) two reasons. First, corruption, of all levels and types, is one of the most publicized types of crime. Thus, the president, or DOJ more generally, may encourage federal prosecutors to crack down on crimes of corruption in order for the current administration to appear more trustworthy and honest. ${ }^{38}$ These incentives to alter corruption prosecutions, and consequently convictions, will likely be stronger when the state is more important to win in a presidential election, i.e., when the state is more politically important. Second, it is possible that politicians in politically important states are more willing to engage in corruption because the returns for doing so are much higher. In this case, we may also see a boost in corruption convictions within those states

\footnotetext{
${ }^{37}$ Out of the 445 cases examined in Gordon (2009), only 184 had an identifiable party connection.

${ }^{38}$ Naturally, an increase in prosecutions is going to be correlated with an increase in convictions. However, PIN data is only available for the latter.
} 
even without any prosecutorial bias. Regardless of whether the increases in corruption convictions come from prosecutorial bias, or because politicians are actually engaging in more corruption, we will see that corruption convictions differ systematically based on political importance.

It is also important to note that the first reason given above may only hold when the governor of the state is of the opposing party. Boosting corruption convictions may only be perceived positively by voters in states where the governor is of the opposing party. This is because voters may view corruption convictions in that state as reflecting badly on the president's political party. In other words, while an administration may want to boost corruption convictions in politically important states, they may do so more cautiously when the state is run by a political ally. Thus, it will be important to consider the political party of the governor as well.

A precursory look at the data suggests that this is in fact what occurs. I estimate the mean corruption convictions and corruption conviction rates of states across four different groups of interest in table 4.1. First, I split the 50 states into two separate groups of political importance: states with a political importance level that is below the median (called non-politically important states) and states with a political importance level above the median (called politically important states) (table 4.1 Comparison Group 1) ${ }^{39}$ Using these two groups, I show that while the total number of corruption convictions and corruption convictions per 10,000 government employees, are higher in politically important states, the number of corruption convictions per 100,000 people are lower in these same states. Thus, no clear pattern presents itself, however, as

\footnotetext{
${ }^{39}$ Regressions will include IMPORTANCE as a continuous variable, rather than breaking into two groups. This is done here for illustrative purposes only. The median level of political importance over the sample is 0.341 .
} 
mentioned above, we need to also consider the political party of the state's governor to determine how political importance effects the state's number of corruption convictions.

Table 4.1: Testing for differences in the means in PIN corruption data.

\begin{tabular}{|c|c|c|c|c|c|}
\hline \multirow[t]{3}{*}{ Comparison Group } & \multicolumn{2}{|c|}{ (1) } & \multicolumn{2}{|c|}{ (2) } & \\
\hline & \multicolumn{2}{|c|}{ Politically Important States } & \multicolumn{2}{|c|}{ Non-Politically Important States } & Hypothesis \\
\hline & Mean & Obs. & Mean & Obs. & Mean $(1)-$ Mean $(2)>0$ \\
\hline Convictions & 29.713 & 125 & 7.384 & 125 & $* * *$ \\
\hline \multirow[t]{2}{*}{ Rate (gov. emp.) } & 0.393 & 125 & 0.363 & 125 & \\
\hline & \multicolumn{2}{|c|}{ Governor Same Party } & \multicolumn{2}{|c|}{ Governor Opp. Party } & Hypothesis \\
\hline Rate (population) & 0.316 & 82 & 0.336 & 168 & \\
\hline \multirow[t]{3}{*}{ Rate (gov. emp.) } & 0.351 & 82 & 0.391 & 168 & $*$ \\
\hline & \multicolumn{2}{|c|}{ Politically Important \& Same Party } & \multicolumn{2}{|c|}{ Politically Important \& Opp. Party } & Hypothesis \\
\hline & Mean & Obs. & Mean & Obs. & $\operatorname{Mean}(1)-\operatorname{Mean}(2)<0$ \\
\hline Convictions & 23.235 & 42 & 32.991 & 83 & $* *$ \\
\hline Convictions & 7.894 & 40 & 7.144 & 85 & \\
\hline Rate (population) & 0.380 & 40 & .334 & 85 & \\
\hline Rate (gov. emp.) & 0.390 & 40 & .350 & 85 & \\
\hline \multicolumn{6}{|c|}{$\begin{array}{l}\text { Notes: } * * * \text { indicates statistically different at } 1 \% \text { level, } * * \text { indicates statistically different at } 5 \% \text { level, } * \text { indicates statistically } \\
\text { different at } 10 \% \text { level. For the sole purposes of comparison in this table } 4 . \text { only, governor same party means governor is of same } \\
\text { political party as president for the entire presidential term. In addition, politically important versus non-politically important } \\
\text { uses the median (0.34) of IMPORTANCE as its cutoff. }\end{array}$} \\
\hline
\end{tabular}

Comparing states with a governor of the same political party as the president for the entire presidential term with states that have a governor of an opposing party, we see that in all cases corruption convictions and its rate are lower when the governor clearly identifies as being the same party as the president (table 4.1 Comparison Group 2). In two out of the three cases the mean is statistically lower for the states that have a governor of the same party. It is important to note that Cordis and Milyo (2016) show election related crimes such as vote fraud, vote suppression, and campaign financing violations are extremely rare using data from administrative records, thus election crimes cannot explain these differences. 
Taking this one step further and comparing only politically important states, I show that the mean is statistically lower for states that have a governor of the same party in all three cases (table 4.1 Comparison Group 3). Lastly, when comparing only non-politically important states, the significant effects completely disappear (table 4.1 Comparison Group 4). In fact, nonpolitically important states with governors of the same party as the president may experience more corruption convictions, though the means are not statistically greater for those states. Taken together, this preliminary evidence suggests that political importance does have an influence on corruption convictions.

Convictions may be influenced by congressional oversight committees as well, especially since the PIN data is developed as a report to Congress. Congress may influence corruption convictions through "congressional dominance” (Weingast and Moran, 1983; Weingast, 1984; Weingast and Marshall, 1988; Moe, 1987). The actions of PIN, and more broadly the DOJ, are overseen by several different congressional oversight committees. Members of these committees may possess punishment and reward mechanisms that they wield to incentivize the agency in question (PIN) to act in their own best interest, even in the absence of action (Weingast and Moran, 1983). Congressional oversight committees also place a constraint on the executive, making it difficult for the executive to exercise a bias when the members are of the opposing party.

Congressional influence is likely dominated by party loyalty, making the political party of the committee members important. ${ }^{40}$ However, the direction of influence is unclear and

\footnotetext{
${ }^{40}$ For example, according to the Congressional Research Service the average length of service for Representatives was 9.1 years, or 4.6 terms, and 10.2 years, or 17 terms for Senators for the $113^{\text {th }}$ Congress. In both the Senate and House, reelection rates averaged above $80 \%$ and often above $90 \%$ from 1990 to today (Center for Responsive Politics). This indicates that once elected to office, members of congress are usually not concerned about getting reelected.
} 
likely depends on the political importance of the state. On the one hand, corruption convictions may increase in politically important states when committee members are of the same political party as the president simply because the DOJ is no longer monitored by the opposing party. For example, the Democrat dominated Congress spurred the investigations into the reasoning behind the dismissal of several federal prosecutors during the Republican (George W.) Bush administration. However, as mentioned above, since a majority of corruption cases do not involve partisan identifiable defendants (Gordon, 2009), this effect is likely small overall.

Alternatively, having more committee members of the same political party as the president may simply indicate that the state is currently under the control of that specific political party. Despite the apparent control of the political party, a close presidential election in that state could indicate that the image of the presidential party is suffering. Voters may associate corruption convictions with more corruption, not better enforcement, and attribute this to being a characteristic of the political party of the president. Thus, a politically important state with more congressional committee members of the same political party as the president may then experience less corruption convictions as a result of an effort to preserve the party's image. This is true even if committee members do not actively influence convictions. This effect is likely stronger than the executive constraint effect since it does not involve partisan bias in the choice of cases to take on.

There have been several papers exploring the effects both executive influence and congressional influence have on several different government agencies and actions. For example, researchers have found one or both influences to be important in determining how government recovery spending is allocated across states in regards to economic crises (Wright, 1974; Anderson and Tollison, 1991; Couch and Shughart, 1997; Young and Sobel, 2013) and natural 
disasters (Garret and Sobel, 2003). In addition to government spending, presidential and congressional influences have also shown to be important in determining the actions of the Internal Revenue Service (IRS) (Young, et al., 2001), the Federal Trade Commission (FTC) (Faith et al., 1982), the Federal Energy Regulatory Commission (FERC) (Kosnik, 2005), Department of Homeland Security (Coats et al., 2006), and the Center for Disease Control (Ryan, 2014).

This paper relates to these previous studies by showing that corruption convictions do vary based on political factors. I use average federal corruption convictions and conviction rates over five consecutive presidential terms from 1993-2012 to show that states important to win in a presidential election tend to have more corruption convictions overall. This effect becomes smaller in magnitude when these politically important states have a governor and a larger number of congressional committee members of the same political party as the president. Interestingly, it seems that these effects are stronger in Democratic presidential administrations.

The data, along with a further review of the literature is presented in section 2. Section 3 presents the empirical methodology. Section 4 summarizes the results, while section 5 concludes.

\subsection{Data}

The data for this paper is divided into five consecutive four-year periods according to presidential terms served from 1993 to 2012 in an attempt to estimate the effect political and congressional influence has on federal corruption convictions. Overall, the data can be classified into four broad groups: measures of corruption, measures of executive influence, measures of congressional dominance, and basic controls. Sources, a brief description, and summary statistics 
of each variable are given in table 4.2 and table 4.3. The remainder of this section will discuss

the construction and sources of each data group in turn.

Table 4.2: Summary Statistics of Corruption Measures (Dependent Variables) \& Political Influence Measures (Independent Variables).

\begin{tabular}{|c|c|c|c|c|c|}
\hline Variable & Brief Description & Mean & $\begin{array}{l}\text { Std } \\
\text { Dev }\end{array}$ & Min. & Max. \\
\hline \multicolumn{6}{|l|}{ Corruption } \\
\hline \multicolumn{6}{|c|}{ US Department of Justice Public Integrity Section Corruption Convictions } \\
\hline CONVICTIONS & Avg. no. of corruption convictions of public officials in each state. & 18.549 & 22.011 & 0 & 124.25 \\
\hline RATE & Avg. no. of corruption convictions of public officials per 100,000 people. ${ }^{1}$ & 0.329 & 0.216 & 0 & 1.109 \\
\hline RATE_GOV & $\begin{array}{l}\text { Avg. no. of corruption convictions of public officials per } 10,000 \text { gov. } \\
\text { employees. }{ }^{1}\end{array}$ & 0.378 & 0.229 & 0 & 1.263 \\
\hline \multicolumn{6}{|l|}{ Presidential Influence } \\
\hline IMPORTANCE & Political importance of each state; higher number means more import. ${ }^{2}$ & 0.531 & 0.589 & 0.100 & 3.737 \\
\hline ELECTORAL & Number of electoral votes allocated to each state. ${ }^{2}$ & 10.700 & 9.532 & 3 & 55 \\
\hline VOTE_CLOSENESS & Political importance of each state without electoral count. ${ }^{2}$ & & & & \\
\hline SAME_PARTY_AS_PRES & Indicates if governor of state is same political party as president. ${ }^{3}$ & 0.464 & 0.425 & 0 & 1 \\
\hline \multicolumn{6}{|l|}{ Oversight Committees } \\
\hline COMMITTEE & Avg. no. relevant committee members. ${ }^{5}$ & 4.830 & 4.225 & 0 & 27 \\
\hline JUDICIAL & Avg. no. of Judicial committee members. ${ }^{5}$ & 1.162 & 1.502 & 0 & 10 \\
\hline GOV & Avg. no. of Governmental Affairs/Reform committee members. ${ }^{5}$ & 1.140 & 1.271 & 0 & 6 \\
\hline APPROPRIATIONS & Avg. no. of Appropriations committee members. ${ }^{5}$ & 1.816 & 1.484 & 0 & 8 \\
\hline INTELLIGENCE & Avg. no. of Intelligence committee members. ${ }^{5}$ & 0.712 & 0.898 & 0 & 5 \\
\hline COMMITTEE_MAJ_PRES & $\begin{array}{l}\text { Avg. no. of committee members in committee majority party and same } \\
\text { party as president. }\end{array}$ & 1.530 & 2.222 & 0 & 19 \\
\hline \multicolumn{6}{|c|}{$\begin{array}{l}{ }^{1} \text { Data on population and government employment come from the Bureau of Economic Analysis. } \\
{ }^{2} \text { Number of electoral votes comes from the Federal Election Commission. } \\
{ }^{3} \text { Political party of state governor comes from the Book of the States, various years. } \\
{ }^{4} \text { Congressional committee membership data comes from the Almanac of American Politics; committee data not available in year } 2012 . \\
{ }^{5} \text { Enters regressions with house members normalized by congressional representation. }\end{array}$} \\
\hline
\end{tabular}

Table 4.3: Summary Statistics and brief variable descriptions of basic controls.

\begin{tabular}{|c|c|c|c|c|c|}
\hline Variable & Brief Description & Mean & $\begin{array}{l}\text { Std. } \\
\text { Dev. }\end{array}$ & Min. & Max. \\
\hline Basic Controls & $\begin{array}{l}\text { When possible, all basic controls are included as averages over the } \\
\text { relevant presidential term. }\end{array}$ & & & & \\
\hline$J U D \_W A G E$ & $\begin{array}{l}\text { Federal gov. expenditures on salaries and wages per-capita for USDOJ } \\
\text { employees by state. }{ }^{1,4}\end{array}$ & 20.327 & 17.986 & 4.312 & 158.95 \\
\hline$J U D \_A I D$ & Federal gov. aid per-capita for USDOJ programs. & 14.244 & 16.766 & 4.587 & 212.69 \\
\hline FEDERAL_AID & Federal aid per-capita to state and local governments. ${ }^{1,4}$ & 1,422 & 588 & 605 & 4502 \\
\hline PRC_VOTE & Percent of state population that voted in the presidential election. ${ }^{3}$ & 0.423 & 0.059 & 0.299 & 0.570 \\
\hline DENSITY & Thousand people per square mile. ${ }^{1}$ & 0.186 & 0.252 & 0.001 & 1.199 \\
\hline$P O P$ & Population estimates (in thousands). ${ }^{2}$ & 5,753 & 6,326 & 482 & 37,491 \\
\hline INCOME & Personal income per-capita. ${ }^{2,7}$ & 32,868 & 5,772 & 20,916 & 51,081 \\
\hline BACHELORS & Percent of population ages 25 or above with at least a bachelor degree. ${ }^{1}$ & 0.254 & 0.049 & 0.126 & 0.389 \\
\hline MEDIAN_AGE & Median age of population. ${ }^{1}$ & 36.642 & 2.518 & 26.875 & 43.225 \\
\hline FIRST_TERM & Variable indicating if president in office was eligible for reelection. ${ }^{3}$ & 0.6 & 0.491 & 0 & 1 \\
\hline DEMOCRAT & Variable indicating if Democratic president in office. ${ }^{3}$ & 0.6 & 0.491 & 0 & 1 \\
\hline TIME_TREND & Linear time trend. & & & & \\
\hline $\begin{array}{l}1 \text { Data comes from } \\
{ }^{2} \text { Data comes from } \\
{ }^{3} \text { Data comes from } \\
{ }^{4} \text { Data enters regre }\end{array}$ & $\begin{array}{l}\text { es Census Bureau. } \\
\text { of Economic Analysis. } \\
\text { Election Commission. } \\
\text { ged form. }\end{array}$ & & & & \\
\hline
\end{tabular}




\section{i. $\quad$ Corruption Measures}

The main corruption measure comes from the Public Integrity Section's Report to Congress on the Activities and Operations of PIN from various years and is included as an average over the entire presidential term. ${ }^{41}$ These reports list federal corruption convictions by judicial districts within each state. Therefore, one simple measure of corruption this paper will use is the total number of federal corruption convictions in each state, by summing the number of convictions across each judicial district in the state (CONVICTIONS). However, while this will be valuable for comparing politically important states alone, it is less valuable when comparing politically important states with states that are significantly less politically important. In general, one would expect politically important states to have more corruption convictions just because they likely also have a larger population and government workforce. Therefore, I construct two alternative corruption conviction measures that are common in the literature and take this into account.

Specifically, much of the existing research uses federal corruption conviction rates as a measure of corruption across states. Although other variations could be established, the most common federal corruption conviction rate used is the number of corruption convictions per 100,000 people (RATE) (e.g. Glaeser and Saks, 2006). Another measure is the number of corruption convictions per 10,000 government employees (RATE_GOV) (e.g. Goel and Nelson, 1998). However, since relatively few studies use this latter measure and this latter measure

\footnotetext{
${ }^{41}$ I chose to use corruption convictions throughout the entire presidential term as this is when the president is clearly in charge and when the US Attorney will have the most incentive to bias the survey in the president's favor. However, given that convictions are difficult to time, I check the robustness of results looking at average corruption convictions in immediate years surrounding the election as Cordis and Milyo (2013) estimate that the average corruption case takes one to two years from referral to conviction. The results are not sensitive to this specification in terms of the signs of the relationships, however, much of the statistical significance is lost. Results using this alternative measure are available upon request.
} 
produces results almost identical to corruption convictions weighted by population I do not report results use $R A T E \_G O V$, but they are available upon request.

\section{ii. Executive Influence}

A president is more likely going to be politically concerned about a state if he or she is on the verge of winning that state in a presidential election. Additionally, politicians may be more inclined to engage in corruption in these states because the rewards for doing so are much higher. In this section, I develop an index that measures political importance of each state overall. A map of this index is given in figure 4.1.

Figure 4.1: Map of Political Importance across the 48 Contiguous U.S. States.

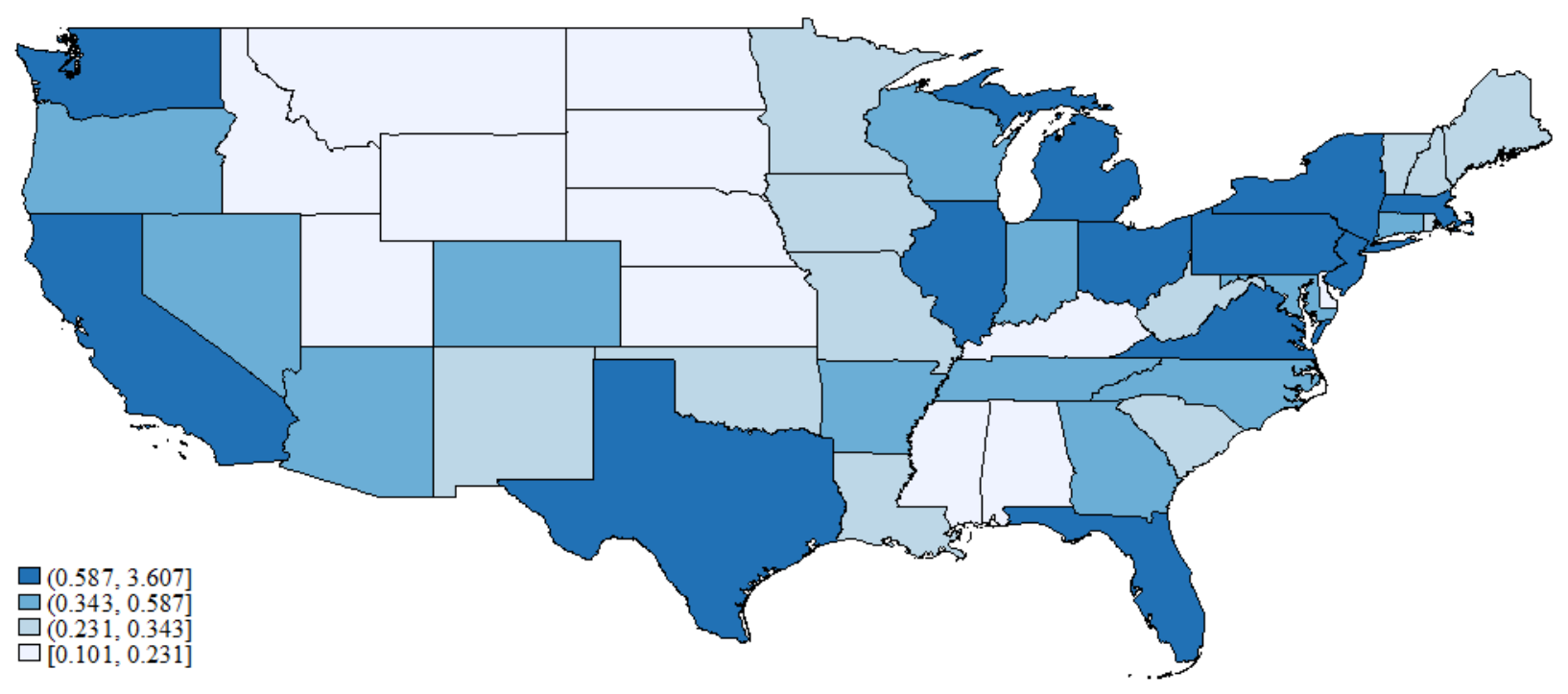

States that are nearly split in their votes are going to be the most important ones. This importance will be further amplified by the number of electoral votes allocated to that state and the easiness of swaying voters in that state. Following Garret and Sobel (2003), I construct a measure of electoral importance that captures both of the above characteristics of politically 
important states. First, I use a formula to calculate the "closeness" of each election. This formula is defined as follows:

$$
\text { CLOSENESS }_{s, t}=1-4 \times\left(P E R C E N T_{-} D E M O C R A T_{s, t}-0.50\right)^{2}
$$

where $s$ indexes the state, $t$ indexes the year of the presidential election, and

PERCENT_DEMOCRAT represents the fraction of votes in the presidential elections that are for the democratic candidate. ${ }^{42}$ Note that the maximum of this formula is 1 , indicating that exactly $50 \%$ of the votes are for the democratic candidate and the election is extremely close in that state. While, the minimum of the formula is 0 , indicating that exactly $100 \%$ (or $0 \%$ ) of the votes were for the democratic candidate and the election was dominated by one party or another in that state.

However, since not all states count the same in presidential elections, CLOSENESS needs to be weighted by electoral votes. Thus, I multiply equation (4.2.1) by the number of electoral votes allocated to the state resulting in the following:

$$
G A R R E T \_S O B E L_{s, t}=C L O S E N E S S_{s, t} \times E L E C T O R A L_{-} V O T E S_{s, t}
$$

where $s, t$ and CLOSENESS are defined as above and ELECTORAL_VOTES represents the number of electoral votes allocated to the state at the time of the presidential election. Equation (4.2.2) is the electoral importance variable used in Garret and Sobel (2003). However, since this paper is interested in the ability of the executive to influence corruption convictions in order to sway voters, it is likely that regardless of the closeness of the election, some states are much easier to sway than others. Thus, similar to the electoral importance measure used in Young et al.

\footnotetext{
${ }^{42}$ Note that this formula treats positive and negative differences between PERCENT_DEMOCRAT and 0.5 exactly the same. The reason being is that this measure looks to focus on the closeness of elections, not necessarily whether the party is winning or losing. However, incentives may be stronger for a presidential administration on the verge of losing a state to alter corruption convictions even more. Thus, this assumption will be discussed further and in some cases, relaxed, in the results section of this paper (table 4.6).
} 
(2001), I multiply equation (4.2.2) by the standard deviation of the percentage of votes for the democratic candidate over the entire sample period for each state. ${ }^{43}$ Thus, the electoral importance variable used in this paper is given by the following:

$$
I M P O R T A N C E_{s, t}=G A R R E T_{-} S O B E L_{s, t} \times S T D \_D E M O C R A T_{s}
$$

where $s, t$, and GARRET_SOBEL are defined as above and STD_DEMOCRAT represents the standard deviation of the percentage of votes for the democratic candidate over the entire sample period for each state. Taken together, this measure says that states that have close elections, with more electoral votes, and a population that is easier to sway are more politically important to the president. ${ }^{44}$

In addition to the political importance of a state, a presidential administration may also be concerned with their party's image in that state. For this reason, executive influence may differ between states that have a governor that is of the same political party as the governor and those that are not. Given that presidential elections and gubernatorial elections are often in separate years, it may very well be the case that the state governor switches parties during a presidential election. To capture this, I include a variable equal to the percentage of years that the governor is of the same political party as the president (SAME_PARTY_AS_PRES). In addition, since executive influence is likely only important in politically important states this variable will be interacted with the political importance variable described above $\left(I M P O R T \times S A M E \_P A R T Y\right)$.

\footnotetext{
${ }^{43}$ Young et al. (2001) actually calculate a variable that is higher for states in which the election was not close and lower for states in which the election was close. Given this, they actually divided their (not) closeness variable by the standard deviation of democrat votes.

${ }^{44}$ Since it is possible that electoral votes dominate this measure, and some states like California with the largest number of electoral votes (55) may be dominated by one political party making them less politically important in reality, I estimate the results with ELECTORAL_VOTES and CLOSENESS $\times$ STD_DEMOCRAT separately as measures of political importance in Chapter 4, Appendix B of this paper. The results remain unchanged in terms of the sign patterns, however they do lose their statistical significance. This indicates that it is important to look at all three together, rather than separately, and shows that including the number of electoral votes in states like California does not lead to incorrect inferences regarding political importance.
} 


\section{iii. $\quad$ Congressional Measures}

Congress may influence corruption convictions through its various oversight committees. According to the Federal Bureau of Investigation (FBI) there are eight primary oversight committees in Congress that regularly oversee the actions of the FBI. ${ }^{45}$ These committees include four Senate committees (Judiciary, Governmental Affairs, Appropriations, and Intelligence) and four House committees (Judiciary, Oversight and Government Reform, Appropriations, and Intelligence). Given that the FBI is a part of the DOJ and that 80 percent of corruption case referrals come from the FBI (Alt and Lassen, 2012), it seems reasonable to assume that together these eight committees exhibit considerable supervision of corruption cases in general.

To begin, I follow the previous literature and simply count the total number of committee members, regardless of political party, each state has on these eight oversight committees (COMMITTEE) for each presidential term. However, states with more members overall are also more politically important making these two variables highly correlated $(r=0.88$ correlation in this sample) and difficult to distinguish in a regression. This occurs because while each state gets exactly two Senators, the number of Representatives is equal to the number of congressional districts in that state, where the number of congressional districts in the state is directly related to the number of electoral votes. Thus, to attempt to control for this effect, I normalize the House committee members by the total number of Representatives that exist for each state.

As mentioned above, the main incentive driving congressman is likely party loyalty. In addition, since each committee has a majority party, it is likely that congressman will have more influence if they are part of the majority party. For example, the 2007 congressional investigation

\footnotetext{
${ }^{45}$ http://www.fbi.gov/news/stories/2004/october/responding_100404.
} 
into why the federal prosecutors were dismissed from duty under the Republican (George W.)

Bush administration likely would not have occurred if Congress were dominated by Republicans instead. To capture these ideas I count the number of committee members each state has that are the same political party as the present and are on committees with a majority party that is the same as the president (COMMITTEE_MAJ_PRES $).{ }^{46}$ As described in the previous section, the effect of committee members of the same party as the president is likely going to be most important in politically important states thus I include and interaction between COMMITTEE_MAJ_PRES and IMPORTANCE as well.

\section{iv. Basic Controls}

In addition to the political variables as described above, I also include several controls that are common in the literature and have been found to influence corruption conviction rates specifically. First, I include three variables that are intended to capture the federal governments involvement in each state (JUD_WAGE, JUD_AID, and FEDERAL_AID) averaged over each presidential term. One way the federal government can influence federal corruption convictions is by decreasing (or increasing) the resources the federal investigation agencies or courts have access to in that state (Alt and Lassen, 2012). To control for this I include per-capita federal government expenditures on salaries and wages and federal aid for US Department of Justice programs by state $\left(J U D \_W A G E ; J U D \_A I D\right)$.

The federal government can also influence activities in general in each state by providing federal aid to the state. To control for this, I include federal aid per-capita given to each state (FEDERAL_AID). Aid in general has been found to impact corruption in the international arena

\footnotetext{
${ }^{46}$ In a previous version, I included only committee members of the majority party, regardless of the president's party finding insignificant results. Therefore, it seems that it is the combination of being in the majority party and being the same party as the president that is what matters.
} 
(e.g., Tavares, 2003; Okada and Samreth, 2012), so it is likely for this to be an important factor here as well.

In general, a democratic society is likely less corrupt than a nondemocratic one (Treisman, 2007). A major reason for this is that politicians in democratic countries can be held accountable for their actions through the voting process. Translating this theory to areas within the US, a state population that is more politically active is also more likely to be aware of and report corrupt activities which could potentially alter the number of corruption conviction in each state. In addition, a more politically active population may actually be easier to sway from a presidential standpoint resulting in the executive having more of an incentive to alter corruption convictions in that state. To control for this I include the percent of the population that votes each presidential election in each state (PRC_VOTE).

In addition to these federal government and political variables I also control for more standard determinants of corruption averaged over the presidential term. For example, I include percent of the adult population with a bachelor degree or higher (BACHELORS), population density (DENSITY), log of total population $(P O P)$, and log of personal income per-capita (INCOME) as in Glaser and Saks (2006). ${ }^{47}$ In addition, I include the median age of the population (MEDIAN_AGE) to reflect any differences in states that vary by age that are not captured by the other variables in the model. Lastly, when possible, dummy variables indicating whether the president is in his or her first term (FIRST_TERM) and whether the president is a democrat or republican (DEMOCRAT) are included. Regional dummy variables are also included

\footnotetext{
${ }^{47}$ Glaeser and Saks (2006) actually include the percent of the population that is living in an urban area rather than population density. However, since this data is only available in Census years and the Census definition of an "urban area" changes over time, this paper is using population density in its place.
} 
according to the ten Census regions, in addition to a yearly time trend (TIME_TREND). All controls are included as averages over the relevant four-year period.

\subsection{Methodology}

This paper uses a least-squares panel data analysis to estimate the effect of executive and congressional influence over the number of corruption convictions and its rate. Namely, I estimate the following relationship:

$$
\begin{aligned}
& \text { CORRUPTION }_{s, t}=\alpha_{0}+\beta_{0} I M P O R T A N C E_{s, t}+\beta_{1} S A M E_{-} P A R T Y \_A S \_P R E S_{s, t}+ \\
& \beta_{2} I M P O R T \times S A M E \_P A R T Y_{s, t}+\beta_{3} C O M_{s, t}+\theta X_{s, t}+\lambda_{r}+\varepsilon_{s, t}
\end{aligned}
$$

where $s, t$, and $r$ index the state, presidential term, and region, respectively; CORRUPTION is one of the measures of corruption convictions as described above; IMPORTANCE and SAME_PARTY_AS_PRES are as described above; IMPORT $\times S A M E \_P A R T Y$ is the interaction between IMPORTANCE and SAME_PARTY_AS_PRES; COMMITTEE is one of the measures of normalized congressional influence as described above; $\theta$ is a vector of coefficients that correspond to the basic controls included in $X$ as described above; $\gamma$ represents linear time trend; $\lambda$ represents Census region dummies; and $\varepsilon$ is the error term. Regional dummies are chosen over state fixed effects for the main results because many of the variables included in the model do not vary greatly over the time periods chosen and thus their impact would likely be overpowered by the fixed effects (see e.g., Glaeser and Saks, 2006). Regressions with state fixed effects are always reported for robustness.

Equation (4.3.1) will first be estimated using total number of normalized committee members (COMMITTEE), and total number of normalized committee members broken down by type of committee (JUDICIAL; GOV; APPROPRIATION; and INTELLIGENCE), as done in the previous literature. I estimate (4.3.1) for democratic and republican administrations separately, to 
see if the effect is different across the political parties. In addition, I estimate (3.1) for democratic majority vote states and republican majority vote states separately, to see if the effect differs depending on whether PERCENT_DEM - 0.5 is greater or less than zero. Essentially, I am allowing PERCENT_DEM $=0.6$ to have a different effect than PERCENT_DEM=0.4. If different effects are found, this may indicate that presidential incentives differ depending on whether or not they are winning or losing a state. In states where the party of the presidential administration is losing the battle, there may be more of an incentive to sway voters in their favor to try to turn the race around.

Lastly, to test if congressional influence is driven by party loyalty I estimate:

$$
\begin{aligned}
& C O R_{s, t}=\alpha_{0}+\beta_{0} I M P O R T A N C E_{s, t}+\beta_{1} S A M E \_P A R T Y \_A S_{-} P R E S_{s, t}+\beta_{2} I M P O R T \times S A M E \_P A R T Y_{s, t} \\
& +\beta_{3} C O M \_M A J \_P R E S_{s, t}+\beta_{4} I M P O R T \times C O M \_M A J \_P R E S_{s, t}+\theta X_{s, t}+\gamma_{t}+\lambda_{r}+\varepsilon_{s, t}
\end{aligned}
$$

where all is defined as in (4.3.1), COM_MAJ_PRES represents the number of committee members in majority power and same party as the president, and IMPORT $\times$ COM_MAJ_PRES is the interaction between IMPORTANCE and COM_MAJ_PRES. In both (4.3.1) and (4.3.2) it is likely that $\beta_{0}>0$, meaning that in politically importance states there are likely going to be more corruption convictions making the current administration appear more trustworthy. Further, in both (4.3.1) and (4.3.2) I expect $\beta_{2}<0$, reducing the positive effect of $\beta_{0}$, as politically important states with a governor of the same party as the president are likely going to have less corruption convictions in order to preserve party image. Importantly, in equation (4.3.2) I expect the positive effect of $\beta_{0}$ to decrease even further when there are more committee members that are of the same political party as the president. Thus, I expect party loyalty and, therefore, executive influence to be dominant. 


\subsection{Results}

For brevity, results are presented only for the main variables of interest: political importance, political party of governor, and the various measures congressional influence. Full results are available in Chapter 4, Appendix A. In every table, excluding the tables presenting marginal effects, column (1) and column (2) include regional fixed effects, while column (3) and column (4) include state fixed effects. Given the little variance in political importance over time, state fixed effects overpower this variable. However, given the potential of omitted variables, results with state fixed effects are included. All congressional measures are normalized by representation.

\section{i. $\quad$ Basic Results}

I present the estimated results of equation (3.1) in their most basic form in table 4.4. I regress executive and congressional influence on corruption convictions using the total number of committee members (panel a) and total number of members broken down by committee type (panel b). In both panels, column (1) and (2) show that both the total number of corruption convictions (CORRUPTION) and the corruption convictions per 100,000 population (RATE) are positively impacted by political importance. In all cases, this positive impact is statistically significant at the one percent level and economically large. For example, a one standard deviation increase in IMPORTANCE (0.589) will lead to an increase of about 14 corruption convictions and an increase of 0.060 in the corruption convictions per 100,000 people when the governor is of the opposing party for the entire presidential term. An increase of 15 corruption convictions explains about 64 percent of a one standard deviation change in the number of convictions. While an increase of 0.07 in RATE explains about 27 percent of a standard deviation 
increase the corruption conviction rate. As expected, this significance disappears when using state level fixed effects.

Table 4.4: The effect of political importance and oversight committee membership on PIN measures of corruption.

\begin{tabular}{|c|c|c|c|c|}
\hline \multicolumn{5}{|c|}{ Panel a: Oversight committee membership in total. } \\
\hline & $\begin{array}{c}\text { CONVICTIONS } \\
\text { (1) }\end{array}$ & $\begin{array}{l}\text { RATE } \\
(2)\end{array}$ & $\begin{array}{c}\text { CONVICTIONS } \\
\text { (3) }\end{array}$ & $\begin{array}{l}\text { RATE } \\
(4)\end{array}$ \\
\hline \multirow{2}{*}{ IMPORTANCE } & $24.504 * * *$ & $0.095 * *$ & 36.711 & 0.288 \\
\hline & $(2.664)$ & $(0.042)$ & $(61.782)$ & $(0.492)$ \\
\hline \multirow[t]{2}{*}{ SAME_PARTY_AS_PRES } & 2.772 & 0.003 & $2.501 *$ & 0.022 \\
\hline & $(1.861)$ & $(0.043)$ & $(1.326)$ & $(0.044)$ \\
\hline \multirow[t]{2}{*}{ IMPORT X SAME_PARTY } & -8.000 & -0.055 & $-9.809 * * *$ & $-0.075^{*}$ \\
\hline & $(4.855)$ & $(0.047)$ & $(3.405)$ & $(0.038)$ \\
\hline \multirow[t]{2}{*}{ COMMITTEE } & 1.089 & 0.017 & 0.152 & 0.013 \\
\hline & $(0.838)$ & $(0.012)$ & $(0.905)$ & $(0.017)$ \\
\hline Observations & 250 & 250 & 250 & 250 \\
\hline $\mathrm{R}^{2}$ & 0.797 & 0.389 & 0.913 & 0.685 \\
\hline State Fixed Effects? & No & No & Yes & Yes \\
\hline \multicolumn{5}{|c|}{ Panel b: Oversight committee membership broken down by type of committee. } \\
\hline & $\begin{array}{c}\text { CONVICTIONS } \\
\text { (1) }\end{array}$ & $\begin{array}{l}\text { RATE } \\
(2)\end{array}$ & $\begin{array}{c}\text { CONVICTIONS } \\
\text { (3) }\end{array}$ & $\begin{array}{l}\text { RATE } \\
(4)\end{array}$ \\
\hline IMPORTANCE & $\begin{array}{c}24.660 * * * \\
(2.530)\end{array}$ & $\begin{array}{c}0.099 * * \\
(0.040)\end{array}$ & $\begin{array}{c}37.943 \\
(61.808)\end{array}$ & $\begin{array}{c}0.326 \\
(0.492)\end{array}$ \\
\hline$S A M E \_P A R T Y \_A S \_P R E S$ & $\begin{array}{c}2.489 \\
(1.878)\end{array}$ & $\begin{array}{l}-0.003 \\
(0.046)\end{array}$ & $\begin{array}{l}2.653 * \\
(1.447)\end{array}$ & $\begin{array}{c}0.029 \\
(0.048)\end{array}$ \\
\hline IMPORT X SAME_PARTY & $\begin{array}{l}-7.745 \\
(4.788)\end{array}$ & $\begin{array}{l}-0.047 \\
(0.046)\end{array}$ & $\begin{array}{c}-9.837 * * * \\
(3.449)\end{array}$ & $\begin{array}{r}-0.077 * \\
(0.039)\end{array}$ \\
\hline JUDICIAL & $\begin{array}{l}-1.333 \\
(1.777)\end{array}$ & $\begin{array}{l}-0.041 \\
(0.025)\end{array}$ & $\begin{array}{c}0.680 \\
(2.058)\end{array}$ & $\begin{array}{c}0.021 \\
(0.029)\end{array}$ \\
\hline GOV & $\begin{array}{c}1.644 \\
(1.747)\end{array}$ & $\begin{array}{c}0.046 \\
(0.030)\end{array}$ & $\begin{array}{c}1.055 \\
(1.718)\end{array}$ & $\begin{array}{c}0.028 \\
(0.041)\end{array}$ \\
\hline APPROPRIATION & $\begin{array}{c}2.451 \\
(1.502)\end{array}$ & $\begin{array}{c}0.046 \\
(0.029)\end{array}$ & $\begin{array}{l}-0.935 \\
(2.034)\end{array}$ & $\begin{array}{l}-0.022 \\
(0.031)\end{array}$ \\
\hline INTELLIGENCE & $\begin{array}{c}2.306 \\
(1.894)\end{array}$ & $\begin{array}{c}0.042 \\
(0.027)\end{array}$ & $\begin{array}{l}-0.162 \\
(1.412)\end{array}$ & $\begin{array}{c}0.020 \\
(0.029)\end{array}$ \\
\hline Observations & 250 & 250 & 250 & 250 \\
\hline $\mathrm{R}^{2}$ & 0.800 & 0.410 & 0.914 & 0.687 \\
\hline State Fixed Effects? & No & No & Yes & Yes \\
\hline
\end{tabular}

However, the interaction, IMPORT $\times S A M E \_P A R T Y$ is negative in every case and statistically significant in every case when state fixed effects are included, greatly reducing the positive impact that IMPORTANCE has. Taking panel a, column (3) for example, a politically important state that has a governor of an opposing party has, on average, 9.8 more corruption 
convictions, than a politically important state with a governor of the same party for the entire presidential term. Thus, politically important states with a governor that is the same political party as the president tend to have lower corruption convictions and corruption convictions rates.

\section{ii. $\quad$ Results Broken Down By Presidential Party}

Next, I estimate equation (3.1) for democratic and republican presidential administrations separately. ${ }^{48}$ These results are presented in table 4.5. As can be seen in the table, democratic administrations seem to be driving the relationship overall as signs remain the same and results remain statistically significant as in table 4.4. When including state-fixed effects, the results for republicans have the same patterns as in table 4.4, however all statistical significances is lost.

Table 4.6 presents the results of equation (3.1) estimated for states that voted a majority democrat and a majority republican, separately. In other words, I split the sample into two groups: (1) PERCENT_DEM - 0.5 greater than zero and the Democratic candidate won the popular vote (panel a); (2) PERCENT_DEM - 0.5 less than zero and the Republican candidate won the popular vote (panel $\boldsymbol{b}$ ). As shown in table 4.6, the results are only significant when the democratic candidate loses the election. Democratic administrations are going to have more of an incentive to sway voters via corruption convictions in states that they are on the verge of losing. In other words, democratic administrations are more likely going to exhibit political influence in states where republicans are winning. Thus, as with table $\mathbf{4 . 5}$, it seems the results are driven by Democratic administrations. However, the general pattern of political importance holds true for both political parties.

\footnotetext{
${ }^{48}$ These results are estimated without the time trend variable as for democratic administration we aren't looking at consecutive periods.
} 


\begin{tabular}{|c|c|c|c|c|}
\hline \multicolumn{5}{|c|}{ Panel a: Democratic Presidential Administrations Only } \\
\hline & $\begin{array}{l}\text { CONVICTIONS } \\
\text { (1) }\end{array}$ & $\begin{array}{c}\text { RATE } \\
(2)\end{array}$ & $\begin{array}{l}\text { CONVICTIONS } \\
\text { (3) }\end{array}$ & $\begin{array}{c}\text { RATE } \\
(4)\end{array}$ \\
\hline IMPORTANCE & $\begin{array}{c}28.698 * * * \\
(2.554)\end{array}$ & $\begin{array}{l}0.077 * \\
(0.039)\end{array}$ & $\begin{array}{c}13.325 \\
(87.534)\end{array}$ & $\begin{array}{l}-0.140 \\
(0.665)\end{array}$ \\
\hline SAME_PARTY_AS_PRES & $\begin{array}{c}4.895 \\
(4.629)\end{array}$ & $\begin{array}{l}-0.033 \\
(0.065)\end{array}$ & $\begin{array}{l}7.466^{*} \\
(4.013)\end{array}$ & $\begin{array}{c}0.109 \\
(0.077)\end{array}$ \\
\hline IMPORT X SAME_PARTY & $\begin{array}{l}-16.648 \\
(10.553)\end{array}$ & $\begin{array}{l}-0.040 \\
(0.094)\end{array}$ & $\begin{array}{c}-22.762 * * \\
(10.053)\end{array}$ & $\begin{array}{c}-0.193 * * \\
(0.086)\end{array}$ \\
\hline СОМMITTEE & $\begin{array}{c}0.444 \\
(0.877) \\
\end{array}$ & $\begin{array}{c}0.009 \\
(0.014) \\
\end{array}$ & $\begin{array}{c}0.304 \\
(0.767) \\
\end{array}$ & $\begin{array}{c}0.011 \\
(0.015) \\
\end{array}$ \\
\hline Observations & 150 & 150 & 150 & 150 \\
\hline $\mathrm{R}^{2}$ & 0.799 & 0.375 & 0.924 & 0.731 \\
\hline State Fixed Effects? & No & No & Yes & Yes \\
\hline \multicolumn{5}{|c|}{ Panel b: Republican Presidential Administrations Only } \\
\hline & $\begin{array}{l}\text { CONVICTIONS } \\
\text { (1) }\end{array}$ & $\begin{array}{c}\text { RATE } \\
(2)\end{array}$ & $\begin{array}{c}\text { CONVICTIONS } \\
\text { (3) }\end{array}$ & $\begin{array}{l}\text { RATE } \\
(4)\end{array}$ \\
\hline IMPORTANCE & $\begin{array}{c}14.218 * * * \\
(2.974)\end{array}$ & $\begin{array}{c}0.115 \\
(0.069)\end{array}$ & $\begin{array}{c}27.381 \\
(112.371)\end{array}$ & $\begin{array}{c}0.742 \\
(2.268)\end{array}$ \\
\hline SAME_PARTY_AS_PRES & $\begin{array}{c}5.135 \\
(3.211)\end{array}$ & $\begin{array}{c}0.115 \\
(0.077)\end{array}$ & $\begin{array}{c}0.250 \\
(5.114)\end{array}$ & $\begin{array}{c}0.056 \\
(0.160)\end{array}$ \\
\hline IMPORT X SAME_PARTY & $\begin{array}{c}1.434 \\
(3.991)\end{array}$ & $\begin{array}{l}-0.082 \\
(0.063)\end{array}$ & $\begin{array}{l}-0.632 \\
(8.240)\end{array}$ & $\begin{array}{l}-0.037 \\
(0.156)\end{array}$ \\
\hline COMMITTEE & $\begin{array}{c}3.167 * * * \\
(0.977)\end{array}$ & $\begin{array}{c}0.045 * * \\
(0.017)\end{array}$ & $\begin{array}{c}2.361 \\
(2.106)\end{array}$ & $\begin{array}{c}0.036 \\
(0.069) \\
\end{array}$ \\
\hline Observations & 100 & 100 & 100 & 100 \\
\hline $\mathrm{R}^{2}$ & 0.865 & 0.482 & 0.970 & 0.845 \\
\hline State Fixed Effects? & No & No & Yes & Yes \\
\hline $\begin{array}{l}\text { Notes: *** indicates statistic } \\
\text { significant at } 10 \% \text { level. Sta } \\
\text { for TIME_TREND and } D E M \\
\text { state-fixed effects. }\end{array}$ & $\begin{array}{l}\text { ificant at } 1 \% \text { level, } \\
\text { ors clustered by sta } \\
\text { Column (1) and cc }\end{array}$ & $\begin{array}{l}\text { s statistica } \\
\text { rentheses. } \\
\text { aclude Cer }\end{array}$ & $\begin{array}{l}\text { at } 5 \% \text { level, * it } \\
\text { is include consta } \\
\text { ed effects, while }\end{array}$ & $\begin{array}{l}\text { tatistically } \\
\text { sic controls e } \\
\text { (3) and (4) in }\end{array}$ \\
\hline
\end{tabular}

\section{iii. $\quad$ Results with Two Interactions}

While executive influence seems to be important, congressional influence as currently measured doesn't seem to have an effect. However, this is likely due to the fact that these committee members are not in the position to influence corruption convictions and I am not properly capturing their personal incentives. Therefore, table 4.7 attempts to account for this by estimating equation (3.2) with the alternative congressional influence measure and its interaction with political importance. 
Table 4.6: The effect of political importance and oversight committee membership on PIN measures of corruption, split into two samples based on whether PERCENT_DEM - .50 is positive or negative.

\begin{tabular}{|c|c|c|c|c|}
\hline & $\begin{array}{l}\text { CONVICTIONS } \\
\text { (1) }\end{array}$ & $\begin{array}{l}\text { RATE } \\
\text { (2) }\end{array}$ & $\begin{array}{c}\text { CONVICTIONS } \\
\text { (3) }\end{array}$ & $\begin{array}{l}\text { RATE } \\
\text { (4) }\end{array}$ \\
\hline IMPORTANCE & $\begin{array}{c}21.003 * * * \\
(2.324)\end{array}$ & $\begin{array}{c}0.016 \\
(0.025)\end{array}$ & $\begin{array}{c}53.402 \\
(62.337)\end{array}$ & $\begin{array}{c}0.490 \\
(0.437)\end{array}$ \\
\hline$S A M E \_P A R T Y \_A S \_P R E S$ & $\begin{array}{c}1.980 \\
(3.397)\end{array}$ & $\begin{array}{l}-0.106 \\
(0.063)\end{array}$ & $\begin{array}{c}4.650 \\
(4.176)\end{array}$ & $\begin{array}{l}-0.051 \\
(0.073)\end{array}$ \\
\hline IMPORT X SAME_PARTY & $\begin{array}{c}-10.464 * * * * \\
(2.921)\end{array}$ & $\begin{array}{l}-0.022 \\
(0.034)\end{array}$ & $\begin{array}{l}-6.303 \\
(5.319)\end{array}$ & $\begin{array}{c}0.018 \\
(0.053)\end{array}$ \\
\hline СOMMITTEE & $\begin{array}{r}-0.050 \\
(1.606) \\
\end{array}$ & $\begin{array}{c}0.023 \\
(0.018) \\
\end{array}$ & $\begin{array}{l}-1.991 \\
(2.029) \\
\end{array}$ & $\begin{array}{l}-0.000 \\
(0.024) \\
\end{array}$ \\
\hline Observations & 102 & 102 & 102 & 102 \\
\hline $\mathrm{R}^{2}$ & 0.859 & 0.448 & 0.949 & 0.759 \\
\hline State Fixed Effects? & No & No & Yes & Yes \\
\hline \multicolumn{5}{|c|}{ Panel a: PERCENT_DEM - .5 is negative (republican majority votes). } \\
\hline & $\begin{array}{c}\text { CONVICTIONS } \\
\text { (1) }\end{array}$ & $\begin{array}{c}\text { RATE } \\
(2)\end{array}$ & $\begin{array}{c}\text { CONVICTIONS } \\
\text { (3) }\end{array}$ & $\begin{array}{l}\text { RATE } \\
\text { (4) }\end{array}$ \\
\hline IMPORTANCE & $\begin{array}{c}56.851 * * * \\
(9.028)\end{array}$ & $\begin{array}{l}0.338^{*} \\
(0.200)\end{array}$ & $\begin{array}{c}39.834 \\
(42.952)\end{array}$ & $\begin{array}{l}-0.213 \\
(0.617)\end{array}$ \\
\hline SAME_PARTY_AS_PRES & $\begin{array}{l}5.214 * * \\
(2.261)\end{array}$ & $\begin{array}{c}0.114 \\
(0.071)\end{array}$ & $\begin{array}{l}4.958^{*} \\
(2.560)\end{array}$ & $\begin{array}{l}0.123 * \\
(0.071)\end{array}$ \\
\hline IMPORT X SAME_PARTY & $\begin{array}{c}-13.260 * * \\
(5.658)\end{array}$ & $\begin{array}{l}-0.193 \\
(0.119)\end{array}$ & $\begin{array}{c}-15.709 * \\
(8.404)\end{array}$ & $\begin{array}{c}-0.219 * * \\
(0.106)\end{array}$ \\
\hline COMMITTEE & $\begin{array}{l}1.297 * \\
(0.756) \\
\end{array}$ & $\begin{array}{c}0.017 \\
(0.017) \\
\end{array}$ & $\begin{array}{c}1.204 \\
(0.733) \\
\end{array}$ & $\begin{array}{c}0.011 \\
(0.026) \\
\end{array}$ \\
\hline Observations & 148 & 148 & 148 & 148 \\
\hline $\mathrm{R}^{2}$ & 0.863 & 0.520 & 0.947 & 0.752 \\
\hline State Fixed Effects? & No & No & Yes & Yes \\
\hline
\end{tabular}

Table 4.7: The effect political importance and oversight committee membership conditional on being the same party as the president on corruption convictions.

\begin{tabular}{lcccc}
\hline & CONVICTIONS & RATE & CONVICTIONS & RATE \\
& $(1)$ & $(2)$ & $(3)$ & 0.236 \\
\hline IMPORTANCE & $25.922^{* * *}$ & $0.100 * *$ & 28.180 & $(0.508)$ \\
SAME_PARTY_AS_PRES & $(2.772)$ & $(0.043)$ & $(63.499)$ & 0.020 \\
& 2.331 & -0.001 & $2.603 *$ & $(0.046)$ \\
IMPORT X SAME_PARTY & $(1.983)$ & $(0.045)$ & $-10.042 * *$ & $-0.072 *$ \\
& -7.405 & -0.048 & $(4.080)$ & $(0.039)$ \\
COMMITTEE_MAJ_PRES & $(4.872)$ & $(0.048)$ & $1.301 *$ & 0.014 \\
& $2.174 * *$ & 0.012 & $(0.700)$ & $(0.013)$ \\
IMPORT X MAJ_PRES & $(0.938)$ & $(0.017)$ & $-2.180 * *$ & $-0.015 *$ \\
& $-2.195 * *$ & -0.008 & $(0.833)$ & $(0.009)$ \\
\hline Observations & $(0.847)$ & $(0.009)$ & 250 & 250 \\
$\mathrm{R}^{2}$ & 250 & 250 & 0.916 & 0.684 \\
State Fixed Effects? & 0.800 & 0.385 & Yes & Yes \\
\hline Notes: *** indicates statistically significant at 1\% level, ** indicates statistically significant at 5\% level, * indicates statistically \\
significant at 10\% level. Standard errors clustered by state are in parentheses. All regressions include constant and basic controls. \\
Column (1) and column (2) include Census region fixed effects, while column (3) and (4) include state-fixed effects. \\
\hline \multicolumn{4}{r}{}
\end{tabular}


As can be seen in the table, the coefficients on both interactions $(I M P O R T \times$

$S A M E \_P A R T Y$; IMPORT $\left.\times C O M \_M A J \_P R E S\right)$ are negative as expected. Further the marginal effects of column (1) and column (2), as shown in table 4.8 and table 4.9, show that the positive effect of IMPORTANCE loses statistical significance and decreases in magnitude when there are a more committee majority members of the same party as the president and when the governor is of the same party as the president. Thus, congressional and executive influences seem to be working in the same direction.

Table 4.8: Conditional marginal effect of IMPORTANCE on corruption convictions, holding COMMITTEE_MAJ_PRES and $S A M E \_P A R T Y \_A S \_P R E S$ at given values.

Panel a: Conditional marginal effect of IMPORTANCE on corruption convictions across different values of COMMITTEE_MAJ_PRES, holding SAME_PARTY_AS_PRES fixed at extreme values.

\begin{tabular}{|c|c|c|c|c|c|}
\hline \multicolumn{2}{|c|}{ COMMITEEE_MAJ_PRES } & \multicolumn{2}{|c|}{$\begin{array}{c}\text { Governor Opposing Party } \\
\text { SAME_PARTY_AS_PRES }=0\end{array}$} & \multicolumn{2}{|c|}{$\begin{array}{c}\text { Governor Same Party } \\
\text { SAME_PARTY_AS PRES }=1\end{array}$} \\
\hline Value Meaning & Value & $d y / d x$ & $p$-value & $d y / d x$ & $p$-value \\
\hline Sample Minimum & 0.000 & 25.922 & 0.000 & 18.517 & 0.004 \\
\hline Sample Median & 0.250 & 25.373 & 0.000 & 17.968 & 0.004 \\
\hline Sample Mean & 0.563 & 24.687 & 0.000 & 17.281 & 0.004 \\
\hline Sample Maximum & 4.500 & 16.046 & 0.000 & 8.640 & 0.030 \\
\hline
\end{tabular}

Panel b: Conditional marginal effect of IMPORTANCE on corruption convictions across different values of SAME_PARTY_AS_PRES, holding COMMITTEE_MAJ_PRES fixed at extreme values.

\begin{tabular}{|c|c|c|c|c|c|}
\hline \multicolumn{2}{|c|}{ SAME_PARTY_AS_PRES } & \multicolumn{2}{|c|}{ COMMITTEE_MAJ_PRES $=0$} & \multicolumn{2}{|c|}{ COMMITTEE_MAJ_PRES $=4.5$} \\
\hline Value Meaning & Value & $d y / d x$ & $p$-value & $d y / d x$ & $p$-value \\
\hline Opposing Party Entire Term & 0.000 & 25.922 & 0.000 & 16.046 & 0.000 \\
\hline Same Party $25 \%$ of Term & 0.250 & 24.071 & 0.000 & 14.195 & 0.000 \\
\hline Same Party $50 \%$ of Term & 0.500 & 22.219 & 0.000 & 12.343 & 0.000 \\
\hline Same Party $75 \%$ of Term & 0.750 & 20.368 & 0.000 & 10.492 & 0.001 \\
\hline Same Party Entire Term & 1.000 & 18.517 & 0.004 & 8.640 & 0.030 \\
\hline
\end{tabular}




\begin{tabular}{|c|c|c|c|c|c|}
\hline \multicolumn{6}{|c|}{$\begin{array}{l}\text { Panel a: Conditional marginal effect of IMPORTANCE on corruption conviction rates across different values of } \\
C O M M I T T E E \_M A J \_P R E S \text {, holding } S A M E \_P A R T Y \_A S \_P R E S \text { fixed at extreme values. }\end{array}$} \\
\hline \multicolumn{2}{|c|}{ COMMITEEE_MAJ_PRES } & \multicolumn{2}{|c|}{$\begin{array}{c}\text { Governor Opposing Party } \\
\text { SAME_PARTY_AS_PRES }=0\end{array}$} & \multicolumn{2}{|c|}{$\begin{array}{c}\text { Governor Same Party } \\
\text { SAME_PARTY_AS PRES }=1\end{array}$} \\
\hline Value Meaning & Value & $d y / d x$ & p-value & $d y / d x$ & $\mathrm{p}$-value \\
\hline Sample Minimum & 0.000 & 0.100 & 0.019 & 0.051 & 0.337 \\
\hline Sample Median & 0.250 & 0.098 & 0.022 & 0.049 & 0.348 \\
\hline Sample Mean & 0.563 & 0.095 & 0.025 & 0.047 & 0.365 \\
\hline Sample Maximum & 4.500 & 0.064 & 0.256 & 0.015 & 0.769 \\
\hline \multicolumn{6}{|c|}{$\begin{array}{l}\text { Panel b: Conditional marginal effect of IMPORTANCE on corruption conviction rates across different values of } \\
S A M E \_P A R T Y \_A S \_P R E S \text {, holding } C O M M I T T E E \_M A J \_P R E S \text { fixed at extreme values. }\end{array}$} \\
\hline \multicolumn{2}{|c|}{ SAME_PARTY_AS_PRES } & \multicolumn{2}{|c|}{ COMMITTEE_MAJ_PRES $=0$} & \multicolumn{2}{|c|}{ COMMITTEE_MAJ_PRES $=4.5$} \\
\hline Value Meaning & Value & $d y / d x$ & $\mathrm{p}$-value & $d y / d x$ & p-value \\
\hline Opposing Party Entire Term & 0.000 & 0.100 & 0.019 & 0.064 & 0.256 \\
\hline Same Party $25 \%$ of Term & 0.250 & 0.087 & 0.031 & 0.052 & 0.313 \\
\hline Same Party $50 \%$ of Term & 0.500 & 0.075 & 0.072 & 0.040 & 0.418 \\
\hline Same Party $75 \%$ of Term & 0.750 & 0.063 & 0.173 & 0.028 & 0.577 \\
\hline Same Party Entire Term & 1.000 & 0.051 & 0.337 & 0.015 & 0.769 \\
\hline
\end{tabular}

\subsection{Conclusion}

In theory, corruption can have a major impact on a variety of economic outcomes. However, the direction of the impact is not always clear. For example, while most researchers argue that corruption is universally bad for growth, other researchers argue that corruption can improve outcomes in certain situations (e.g., Leff, 1964; Huntington, 1968). Thus, being able to empirically test these theories is crucial.

In the US, most theories of corruption are tested using federal corruption conviction rates provided by the US Department of Justice's Public Integrity Section, interpreting a higher rate of corruption convictions to mean there is more corruption in that state. However, these papers have failed to consider how a state's importance in presidential elections might influence the state's corruption, or corruption convictions, to the extent that they are different. This is important for two reasons. First, given that federal corruption convictions are handled by presidentially appointed federal prosecutors that have a significant amount of discretion over case choice, there 
is room for political bias in convictions. More specifically, there may be a particular push in politically important states for corruption convictions as corruption is a highly publicized crime. Second, it is possible that politicians in politically important states are more willing to engage in corruption because the stakes are higher. Regardless of whether the increases in corruption convictions come from prosecutorial bias, or because politicians are actually engaging in more corruption, we will see that corruption convictions differ systematically based on political importance.

Overall, I find evidence that reported federal corruption convictions tend to be higher in politically important states. However, since boosting convictions may not always be perceived positively by voters, it seems that this effect decreases in magnitude and becomes statistically insignificant when states have a governor of the same political party as the president. This is likely because more corruption convictions could possibly be conceived as more corruption, and reflect poorly on the current administration. Similar results hold when the state has more congressional members of the president's party. Thus, corruption convictions are systematically different across states based on political factors.

I hope that future work can develop an alternative, more direct, measure of corruption across the U.S. states. Using this measure it would be interesting to see if the results found here are something specific to corruption convictions, or to corruption in general. If this is something specific to corruption convictions, this supports the idea that it is federal prosecutor bias driving the results. However, if it holds with alternative corruption measures, then perhaps politicians are just more likely going to engage in corruption in politically important states. 


\section{Chapter 5}

\section{Conclusion}

The question of whether corruption is good or bad for growth may seem like an obvious one. Corruption distorts incentives, misallocates resources, and induces uncertainty. However, the empirical literature estimating the consequences of corruption is mixed. In many cases there is a strong negative association between corruption and income levels, in other cases this seemingly robust negative relationship disappears. There are three potential explanations for this: (1) uncertainty regarding corruption is not controlled for when looking at this relationship across countries; (2) the informal sector is ignored; and (3) the measures of corruption are simply not reliable. Chapters 2, 3, and 4 tackle each of these possibilities in turn.

Overall, I find that corruption is negatively associated with economic outcomes. This is found to be true across countries (Chapter 2) and, though less robustly so, within countries (Chapter 3). It seems that some of the mixed results from the cross-country studies stem for the fact that uncertainty regarding corruption is not controlled for. In Chapter 2, I find that the effect of corruption actually depends on the corruption regime in each country. Therefore, it is possible that when a country faces little uncertainty, corruption can be growth enhancing.

Chapter 3, however, shows that corruption may be less important than the size of the informal sector overall in a country where the informal sector is a significant part of the economy. When looking at municipalities within Brazil, I find that the share of employment made up of informal employees has a robustly negative relationship with total income levels, when the effect of corruption is largely insignificant. This is important as much of the countries that have a significant amount of corruption also have an enormous informal sector. 
The conclusion from Chapter 3, however, does not mean that we should stop pursuing anti-corruption policies. It merely suggests that that policies aimed at increasing income should be focused on reducing the size of the informal sector. To do so, one needs to better understand the underlying causes of the informal economy. In low-income countries, corruption is often used to participate in the informal sector. It is possible, then, that reducing corruption does indeed reduce the size of the informal sector.

In developed countries, there are many benefits of partaking in the formal sector. An example of a major benefit is the use of the formal legal system. There are also costs of being a part of the formal sector. This costs include, but are not limited to, paying taxes and abiding by formal rules and regulations. If the costs of engaging in the formal economy outweigh the benefits, individuals will choose to go underground. Future research should be focused on revealing these costs and benefits.

If policy makers find that the benefits firms receive from participating in the formal sector are relatively low, they may think about ways to improve the quality of their public service. Similarly, if policy makers find that the costs to firms for participating in the formal sector are relatively high, they need to think about how to reduce these costs, without sacrificing quality. Perhaps some of the regulations in place are inefficient, causing firms to move underground. In this case, these regulations may not be serving their intended purpose since they are not being followed. Thus, the benefits of these regulations are likely outweighed by the costs.

Relatedly, policy makers need to think more about enforcement. An informal sector that accounts for over half of the workforce as in Brazil indicates that individuals who participate in the informal sector are not being effectively punished. As noted in La Porta and Shleifer (2014), reducing the size of the informal sector in countries where the informal sector is well established 
takes a significant amount of time. This is likely because informality is so well accepted in these countries. Changing this view requires policy makers to be more stringent in their enforcement of rules and regulations. Policy makers can quicken the reduction in informal sector size by encouraging work in the formal sector, and punishing of those who are caught working in the informal sector.

Lastly, I caution researchers in Chapter 4 as I show that one of the most commonly used measures of corruption is politically biased, and therefore unreliable. Special care must be taken when measuring corruption, whether it be internationally or locally. The corruption measure contained in Chapter 3 provides an excellent example on a corruption measure that is reliable. Perhaps more countries could follow Brazil in its extreme transparency allowing researchers to develop novel ways to measure corruption, and possibly increasing political accountability and trust. 


\section{References}

Abed, G. T., Davoodi, H.R. 2002. Corruption, structural reforms, and economic performance in the transition economies. in (Abed and Gupta eds.) Governance, Corruption, and Economic Performance. Washington D.C.: International Monetary Fund.

Acemoglu, D., Johnson, S., Robinson, J.A. 2001. The colonial origins of comparative development: an empirical investigation. American Economic Review 91(5), 1369-1401.

Aidt, T. 2009. Corruption, institutions, and economic development. Oxford Review of Economic Policy 25(2), 271-291.

Alt, J. E., Lassen, D. D. 2008. Political and judicial checks on corruption: Evidence from American state governments. Economics and Politics 20(1), 33-41.

Alt, J. E., Lassen, D. D. 2012. Enforcement and public corruption: Evidence from American states. Journal of Law, Economics, and Organization 10(30), 306-338.

Anderson, G. M., Tollison, R. D. 1991. Congressional influence and patterns of New Deal spending, 1939-1939. Journal of Law and Economics 34(1), 161-175.

Barro, R. J. 1991. Economic growth in a cross-section of countries. Quarterly Journal of Economics 106(2), 407-443.

Barro, R. J., Lee, J. 2010. A new data set of educational attainment in the world, 1950-2010. NBER Working Paper No. 15902.

Barro, R. J., Mankiw, N. G., Sala-i-Martin, X. 1995. Capital mobility in neoclassical models of growth. American Economic Review 85, 103-115.

Barro, R. J., Sala-i-Martin, X. 1992. Convergence. Journal of Political Economy 100(2), 223 251.

Batra, G., Kaufmann, D., Stone, A. H. W. 2003. Investment Climate Around the World: Voices of the Firms from the World Business Environment Survey. Washington D.C.: The World Bank.

Bergh, A., Henrekson, M. 2011. Government size and growth: a survey and interpretation of the evidence. Journal of Economic Surveys 25(5), 872-897.

Berry, W. D., Fording, R. C., Ringquist, E. J., Hanson, R. L., Klarner, C. 2010. Measuring citizen and government ideology in the American states: A re-appraisal. State Politics and Policy Quarterly 10(2), 117 - 135.

Berry, W.D., Ringquist, E. J., Fording, R. C., Hanson, R.L. 1998. Measuring citizen and government ideology in the American states, 1960 - 93. American Journal of Political Science 42(1), 327 - 348.

Bologna, J. 2015. Corruption: the good, the bad, and the uncertain. SSRN Working Paper (http://papers.ssrn.com/sol3/papers.cfm?abstract_id=2379061). 
Bologna, J. 2015a. The effect of informal employment and corruption on income levels in Brazil. Mimeo.

Bologna, J. 2015b. Corruption, product market competition, and institutional quality: empirical evidence from the US states. Mimeo.

Borensztein, E., De Gregorio, J., Lee, J. 1998. How does foreign direct investment affect economic growth? Journal of International Economics 45, 115-135.

Boylan, R. T., Long, C. X. 2003. Measuring public corruption in the American states: A survey of State House reporters 3(4), 420-438.

Campos, J., Lien, D., Pradhan, S. 1999. The impact of corruption on investment: predictability matters. World Development 27(6), 1059-1067.

Choe, J. 2003. Do foreign direct investment and gross domestic investment promote economic growth? Review of Development Economics 7(1), 44-57.

Choi, J. P., Thum, M. 2005. Corruption and the shadow economy. International Economic Review 46(3), 817-836.

Coats, R. M., Karahan, G., Tollison, R. D. 2006. Terrorism and pork-barrel spending. Public Choice 128(1-2), 275- 287.

Cordis, A., Milyo, J. 2013. Measuring public corruption in the United States: Evidence from administrative records of federal prosecutions. University of Missouri Working Paper No. 1322.

Couch, J. F., Shughart II, W. F. 1997. “The Political Economy of the New Deal,” Cheltenham, UK and Northampton, MA: Edward Elgar.

Cravo, T. A., Resende, G.M. 2014. Economic growth in Brazil: a spatial filtering approach. The Annals of Regional Science 50 (2), 555-575.

Cukier, J., Wall, G. 1994. Informal tourism employment: vendors in Bali, Indonesia. Tourism Management 15 (6), $464-467$.

Dal Bó, E., Rossi, M. A. 2007. Corruption and inefficiency: theory and evidence from electric utilities. Journal of Public Economics 91(5-6), 939-962.

Donchev, D. and Ujhelyi, G. 2014. What do corruption indices measure? Economics \& Politics 26(2), 309-331.

Dreher, A., Gassebner, M. 2013. Greasing the wheels? The impact of regulations and corruption on firm entry. Public Choice 155 (3-4), 413-432.

Dreher, A., Herzfeld, T. 2005. The economic costs of corruption: a survey and new evidence. SSRN Working Paper (http://papers.ssrn.com/sol3/papers.cfm?abstract_id=734184).

Dreher, A., Kotsogiannis, C., McCorriston, S. 2009. How do institutions affect corruption and the shadow economy? International Tax and Public Finance 16 (6), 773-796.

Dreher, A., Schneider, F. 2010. Corruption and the shadow economy: an empirical analysis. Public Choice 144 (1), 215-238. 
Faith, R. L., Leavens, D. R., Tollison, R. D. 1982. Antitrust pork barrel. Journal of Law and Economics 25(2), 329-342.

Farrell, D. 2004. The hidden dangers of the informal economy. McKinsey Quarterly 2004, 26-37.

Ferraz, C., Finan, F. 2008. Exposing corrupt politicians: the effects of Brazil's publicly released audits on electoral outcomes. The Quarterly Journal of Economics 123(2), 703-745.

Ferraz, C., Finan, F. 2011. Electoral accountability and corruption: evidence from the audits of local governments. American Economic Review 101(4), 1274 - 1311.

Fisman, R., Svensson, J. 2007. Are corruption and taxations really harmful to growth? Firm level evidence. Journal of Development Economics 83(1), 63-75.

Garrett, T. A., Sobel, R. S. 2003. The political economy of FEMA disaster payments. Economic Inquiry 41(3), 496-509.

Geddes, B., Neto, A.R. 1992. Institutional sources of corruption in Brazil. Third World Quarterly 13(4), 641-661.

Glaeser, E. L., Saks, R. E. 2006. Corruption in America. Journal of Public Economics 90, 10531072.

Goel, R. K., Nelson, M. A. 1998. Corruption and government size: a disaggregated analysis. Public Choice 97(1-2), 107-120.

Goel, R. K., Nelson, M. A. 2011. Measures of corruption and determinants of US corruption. Economics of Governance 12(2), 155-176.

Goldstein, A., Eggen, D. 2007. Renzi aide called U.S. Attorney to ask about probe. The Washington Post, April 26, 2007, http://www.washingtonpost.com/wpdyn/content/article/2007/04/25/AR2007042502707.html.

Gonzales, A., López-Cordóva, J.E., Valladares, E. E. 2007. The incidence of graft on developing-country firms. World Bank Policy Research Working Paper No. 4394.

Gordon, S. C. 2009. Assessing partisan bias in federal public corruption prosecutions. American Political Science Review 103, 534 - 554.

Gordon, S. C., Huber, G. A. 2009. The political economy of prosecution. Annual Review of Law and Social Science 5, 135-56.

Gourinchas, P., Jeanne, O. 2013. Capital flows to developing countries: the allocation puzzle. The Review of Economic Studies 80 (4), 1484 - 1515.

Gwartney, J., Lawson, R., Hall, J. C. 2013. Economic Freedom of the World: 2013 Annual Report. Vancouver: Fraser Institute.

Hall, R.E., Jones, C.I. 1999. Why do some countries produce so much more output per worker than others? The Quarterly Journal of Economics 114(1), 83-116. 
Heckelman, J. C., Powell, B. 2010. Corruption and the institutional environment for growth. Comparative Economic Studies 52, 351-378.

Heckelman, J. C., Wilson, B. 2013. Institutions, lobbying, and economic performance. Economics and Politics 25(3), 360-386.

Hibbs, D. A., Jr., Piculescu, V. 2005. Institutions, corruption and tax evasion in the unofficial economy. Working Paper. Göteborg, University.

Hindriks, J., Keen, M., Muthoo, A. 1999. Corruption, extortion and evasion. Journal of Public Economics 74 (3), 395-430.

Holcombe, R. G., Boudreaux, C. J. 2015. Regulation and corruption. Public Choice 164(1 - 2), 75-85.

Huntington, S. P. 1968. Political Order in Changing Societies. New York: Oxford University Press.

Hussmanns, R. 2005. Measuring the informal economy: from employment in the informal sector to informal employment. Policy Integration Department Working Paper No. 53, Bureau of Statistics International Labour Office, Geneva.

Johnson, N., LaFountain, C., Yamark, S. 2011. Corruption is bad for growth (even in the United States). Public Choice 147(3-4), 377-393.

Johnson, S., Kaufmann, D., Shleifer, A. 1997. The unofficial economy in transition. Brookings Papers on Economic Activity 1997 (2), 159-239.

Kaufmann, D. 2005. Myths and realities of governance and corruption. in (Lopez-Carlos, Porter, and Schwab eds.) The World Economic Forum, Global Competitiveness Report 20052006. New York: Palgrave Macmillan.

Kaufmann, D., Kraay, A., Mastruzzi, M. 2010. The worldwide governance indicators: methodology and analytical issues. World Bank Policy Research Working Paper No. 5430.

Kaufmann, D., Wei, S. 1999. Does "grease money” speed up the wheels of commerce? NBER Working Paper No. 7093.

Kosnik, L. D., 2005. Sources of bureaucratic delay: A case study of FERC dam relicensing. Journal of Law, Economics, and Organization 22(1), 258-287.

La Porta, R. Lopez-de-Silanes, F., Sheifer, A., Vishny, R. 1999. The quality of government. Journal of Law, Economics, and Organization 15(1), 222-279.

La Porta, R., Shleifer, A. 2008. The unofficial economy and economic development. NBER Working Paper Series No. 14520.

La Porta, R., Shleifer, A., 2014. Informality and development. Journal of Economic Perspectives 28(3), $109-126$.

Lambsdorff, J. G. 2003. How corruption affects persistent capital flows. Economics of Governance 4(3), 229-243. 
Leeson, P. T., Sobel, R. S. 2008. Weathering corruption. Journal of Law and Economics 51(4), 667-681.

Leff, N. H. 1964. Economic development through bureaucratic corruption. The American Behavioral Scientist 8 (3), 8-14.

Li, H., Xu, L.C., Zou, H. 2000. Corruption, income distribution, and growth. Economics and Politics 12(2), 155-182.

Lipton, E. 2007a. One prosecutor's ouster central to inquiry. The New York Times, April 19, 2007, http://www.nytimes.com/2007/04/19/washington/19attorneys.html.

Lipton, E. 2007b. Some ask if U.S. attorney dismissals point to pattern of investigating Democrats. The New York Times, May 1, 2007, http://www.nytimes.com/2007/05/01/world/americas/01iht01 corrupt.5510434.html?pagewanted=all.

Loayza, N. A. 1996. The economics of the informal sector: a simple model and some empirical evidence from Latin America. Carnegie-Rochester Conference Series on Public Policy 45, $129-162$.

Loayza, N., Rigolini, J. 2011. Informal employment: safety net or growth engine? World Development 39 (9), 1503-1515.

Lui, F. T. 1985 An equilibrium queuing model of bribery. Journal of Political Economy. 9, 760781.

Mauro, P. 1995. Corruption and growth. Quarterly Journal of Economics 110(3), 681-712.

Mcmillan, J., Zoido, P. 2004. How to subvert democracy: Montesinos in Peru. Journal of Economic Perspectives 18 (4), 69-92.

Méon, P., Sekkat, K. 2005. Does corruption grease or sand the wheels of growth? Public Choice 122, 69-97.

Mo, P. H. 2001. Corruption and economic growth. Journal of Comparative Economics 29, 66 79.

Mocan, N. 2004. What determines corruption? International evidence from micro data. NBER Working Paper No. 10460.

Mocan N. 2008. What determines corruption? International evidence from micro data. Economic Inquiry 46(4), 493-510.

Mocan N. 2009. Corruption, corruption perception, and economic growth. in (Sayan eds.) Economic Performance in the Middle East and North Africa: Institutions, Corruption, and Reform. London: Routledge.

Moe, T. M. 1987. An assessment of the positive theory of 'congressional dominance'. Legislative Studies Quarterly 12(4), 475-520. 
Okada, K., Samreth, S. 2012. The effect of foreign aid on corruption: A quantile regression approach. Economics Letters 115(2), 240-243.

Olken, B. A. 2009. Corruption perceptions vs. corruption reality. Journal of Public Economics 93 (7-8), 950-964.

Olken, B. A., 2007. Monitoring corruption: evidence from a field experiment in Indonesia. Journal of Political Economy 115 (2), 200-249.

Olken, B. A., Barron, P 2009. The simple economics of extortion: evidence from trucking in Aceh. Journal of Political Economy 117(3), 417- 452.

Olken, B. A., Pande R. 2012. Corruption in developing countries. Annual Review of Economics 4, 479-509.

Pederson, S. 2003. The shadow economy in Germany, Great Britain, and Scandinavia: A measurement based on questionnaire surveys. Research Unit Study No. 5, The Rockwool Foundation Research Unit, Copenhagen.

Poole, K. T. 1998. Recovering an issue space from a set of issue scales. American Journal of Political Science 42(3), 954 - 993.

Razafindrakoto, M., Roubaud, F. 2010. Are international databases on corruption reliable? A comparison of expert opinion surveys and household surveys in Sub-Saharan Africa. World Development 38(8), 1057-1069.

Reinikka, R., Svensson, J. 2005. Fighting corruption to improve schooling: evidence from a newspaper campaign in Uganda. Journal of the European Economic Association 3 (2-3), 259-267.

Resende, G. M. 2013. Spatial dimensions of economic growth in Brazil. ISRN Economics 2013. http://dx.doi.org/10.1155/2013/398021.

Rose-Ackerman, S. 2004. The challenge of poor governance and corruption. Mimeo. Copenhagen Consensus and Yale University.

Ryan, M. E. 2014. Allocation infection: The political economy of the Swine Flu (H1N1) vaccine. Economic Inquiry 52(1), 138-154.

Schneider, F. 2005 Shadow economies around the world: what do we really know? European Journal of Political Economy 21(3), 598-642.

Schneider, F. 2007. Shadow economies and corruption all over the world: new estimates for 145 countries. Economics: The Open-Access, Open-Assessment E-Journal 2007-9(2), 1-53. http://dx.doi.org/10.5018/economics-ejournal.ja.2007-9.

Schneider, F., Buehn, A., Montenegro, C. E. 2010. Shadow economics all over the world: new estimates for 162 countries from 1999 to 2007. World Bank Policy Research Working Paper No. 5356.

Schneider, F., Enste, D. H. 2000. Shadow economies: size, causes, and consequences. Journal of Economic Literature 38(1), 77-114. 
Schneider, F., Williams, C.C. 2013. The Shadow Economy. London: The Institute of Economic Affairs.

Sequeira, S., Djankov, S. 2010. An empirical study of corruption in ports. MPRA Paper 21791, University Library of Munich, Germany.

Shleifer, A., Vishny, R. W. 1993. Corruption. Quarterly Journal of Economics 108(3), 599-617.

Silva, M. F. 1999. The political economy of corruption in Brazil. Revista de Administração de Empresas 39(3), 26-41.

Stock, J.H., Yogo, M. 2005. Testing for weak instruments in linear IV regression. NBER Technical Working Paper Series No. 284.

Svensson, J. 2003. Who must pay bribes and how much? Evidence from a cross section of firms. Quarterly Journal of Economics 118(1), 207-230.

Svensson, J., 2005. Eight questions about corruption. Journal of Economic Perspecives. 19(3), 19 -42 .

Swaleheen, M. 2011. Economic growth with endogenous corruption: an empirical study. Public Choice 146, 23-41.

Tavares, J. 2003. Does foreign aid corrupt? Economics Letters 79, 99-106.

Treisman, D. 2007. What have we learned about the causes of corruption from ten years of crossnational empirical research? Annual Review of Political Science 10, 211-244.

Weber Abramo, C. 2008. How much do perceptions of corruption really tell us? Economics: The Open-ACORRUPT_PER_2ess, Open-Assessment E-Journal 2 (2008-3).

Wei, S. 1997. Why is corruption so much more taxing than tax? Arbitrariness kills. NBER Working Paper No. 6255.

Weingast, B. R. 1984. The congressional-bureaucratic system: a principal again perspective (with applications to SEC). Public Choice 44(1), 147-191.

Weingast, B. R., Marshall, W. 1988. The industrial organization of Congress. Journal of Political Economy 96(1), 132-163.

Weingast, B. R., Moran, M. J. 1983. Bureaucratic discretion or congressional control? Regulatory policymaking by the Federal Trade Commission. Journal of Political Economy 91(5), 765-800.

Wiseman, T. 2014. Entrepreneurship, Corruption, and the Size of the U.S. Underground Economies. Journal of Regional Analysis and Policy (forthcoming).

Wright, G. 1974. The political economy of New Deal spending: An econometric analysis. Review of Economics and Statistics 56(1), 30-38.

Young, A. T., Sobel, R. S. 2013. Recovery and Reinvestment Act spending at the state level: Keynesian stimulus or distributive politics? Public Choice 155(3-4), 449-468. 
Young, M., Reksulak, M., Shughart II, W. F. 2001. The political economy of the IRS. Economics and Politics 13(2), 201-220. 


\section{Appendices}

\section{Chapter 2, Appendix A}

Table 2A.1: List of countries included in the World Business Environment Survey.

\begin{tabular}{|c|c|c|c|}
\hline \multicolumn{4}{|c|}{ Country Names } \\
\hline Albania & Czech Republic & Kyrgyz Republic & Slovak Republic \\
\hline Argentina & Dominican Republic & Lithuania & Slovenia \\
\hline Armenia & Ecuador & Madagascar & South Africa \\
\hline Azerbaijan & Egypt, Arab Rep. & Malawi & Spain \\
\hline Bangladesh & El Salvador & Malaysia & Sweden \\
\hline Belarus & Estonia & Mexico & Tanzania \\
\hline Belize & Ethiopia & Moldova & Thailand \\
\hline Bolivia & France & Namibia & Trinidad and Tobago \\
\hline Bosnia and Herzegovina & Georgia & Nicaragua & Tunisia \\
\hline Botswana & Germany & Nigeria & Turkey \\
\hline Brazil & Ghana & Pakistan & Uganda \\
\hline Bulgaria & Guatemala & Panama & Ukraine \\
\hline Cambodia & Haiti & Peru & United Kingdom \\
\hline Cameroon & Honduras & Philippines & United States \\
\hline Canada & Hungary & Poland & Uruguay \\
\hline Chile & India & Portugal & Uzbekistan \\
\hline Colombia & Indonesia & Romania & Venezuela \\
\hline Costa Rica & Italy & Russian Federation & West Bank \\
\hline Cote d'Ivoire & Kazakhstan & Senegal & Zambia \\
\hline Croatia & Kenya & Singapore & Zimbabwe \\
\hline
\end{tabular}

Table 2A.2: Conditional marginal effect of both corruption experience (CORRUPT_EXP) on growth; response bias robustness checks.

Panel a: Average growth from 2000-2005

\begin{tabular}{|c|c|c|c|c|}
\hline & \multicolumn{2}{|c|}{ UNCERT $=1$} & \multicolumn{2}{|c|}{ UNCERT $=6$} \\
\hline & $d y / d x$ & $p$-value & $d y / d x$ & $p$-value \\
\hline Excluding countries in Africa. & 1.549 & 0.107 & -3.408 & 0.008 \\
\hline Excluding firms that left UNCERT blank when CORRUPT_EXP=1. & 1.778 & 0.067 & -2.510 & 0.157 \\
\hline Excluding firms that left either $U N C E R T$ or $C O R R U P T \_E X P$ blank. & 1.601 & 0.099 & -2.407 & 0.210 \\
\hline \multicolumn{5}{|l|}{ Panel b: Average growth from 2000-2011 } \\
\hline & \multicolumn{2}{|c|}{$U N C E R T=1$} & \multicolumn{2}{|c|}{ UNCERT $=6$} \\
\hline & $d y / d x$ & $p$-value & $d y / d x$ & $p$-value \\
\hline Excluding countries in Africa. & 2.533 & 0.005 & -3.562 & 0.001 \\
\hline Excluding firms that left $U N C E R T$ blank when $C O R R U P T \_E X P=1$. & 3.016 & 0.000 & -4.332 & 0.000 \\
\hline Excluding firms that left either $U N C E R T$ or $C O R R U P T \_E X P$ blank. & 2.970 & 0.000 & -4.580 & 0.000 \\
\hline
\end{tabular}




\section{Chapter 3, Appendix A}

Table 3.A1: The effect corruption, as measured by the share of resources ( $\mathrm{R} \$$ ) found to involve corruption, and the informal economy have on GDP per-capita in 2004 and income per-capita from different sources in 2000; without fixed effects.

\begin{tabular}{|c|c|c|c|c|}
\hline & \multirow[b]{2}{*}{$\begin{array}{c}G D P_{(1)} P C_{-} 04 \\
\text { (1) }\end{array}$} & \multicolumn{3}{|c|}{ Types of Income in 2000} \\
\hline & & $\begin{array}{l}\text { TOTAL } \\
\text { (2) }\end{array}$ & $\begin{array}{c}\text { FORMAL } \\
\text { (3) }\end{array}$ & $\begin{array}{c}\text { INFORMAL } \\
\text { (4) }\end{array}$ \\
\hline \multirow{2}{*}{ PROB_CORRUPT } & $-0.417 *$ & -0.044 & -0.051 & $-0.186 *$ \\
\hline & $(0.219)$ & $(0.079)$ & $(0.089)$ & $(0.106)$ \\
\hline \multirow[t]{2}{*}{ SIZE_INFORMAL } & $-0.894 * * *$ & $-0.391 * * *$ & $0.228 * *$ & 0.008 \\
\hline & $(0.202)$ & $(0.078)$ & $(0.108)$ & $(0.105)$ \\
\hline \multirow[t]{2}{*}{ SYNTHESIS } & $0.173 * * *$ & 0.028 & 0.008 & 0.021 \\
\hline & $(0.062)$ & $(0.018)$ & $(0.025)$ & $(0.024)$ \\
\hline \multirow[t]{2}{*}{ POPULATION } & 0.010 & $0.049 * * *$ & $0.086 * * *$ & 0.015 \\
\hline & $(0.041)$ & $(0.013)$ & $(0.017)$ & $(0.019)$ \\
\hline \multirow[t]{2}{*}{$U R B A N$} & -0.017 & $-0.144 * *$ & -0.113 & -0.076 \\
\hline & $(0.207)$ & $(0.066)$ & $(0.091)$ & $(0.088)$ \\
\hline \multirow[t]{2}{*}{ SCHOOL } & $0.163 * * *$ & $0.197 * * *$ & $0.171 * * *$ & $0.127 * * *$ \\
\hline & $(0.053)$ & $(0.020)$ & $(0.026)$ & $(0.025)$ \\
\hline \multirow[t]{2}{*}{ DENSITY } & $-0.115 * * *$ & $-0.059 * * *$ & $-0.056 * * *$ & $-0.048 * * *$ \\
\hline & $(0.028)$ & $(0.009)$ & $(0.012)$ & $(0.013)$ \\
\hline \multirow[t]{2}{*}{ DISTANCE_SP } & 0.030 & $-0.044 * * *$ & $-0.037 *$ & $-0.059 * * *$ \\
\hline & $(0.049)$ & $(0.016)$ & $(0.020)$ & $(0.021)$ \\
\hline \multirow[t]{2}{*}{ TEEN } & -3.391 & $-3.997 * * *$ & -2.064 & $-5.241 * * *$ \\
\hline & $(2.391)$ & $(0.892)$ & $(1.372)$ & $(1.046)$ \\
\hline \multirow[t]{2}{*}{ WORK } & $4.601 * * *$ & $-1.607 * * *$ & -0.897 & $-1.247 * *$ \\
\hline & $(1.242)$ & $(0.486)$ & $(0.729)$ & $(0.610)$ \\
\hline \multirow[t]{2}{*}{ ELDER } & $-5.744 * * *$ & $-4.038 * * *$ & $-2.680 * * *$ & $-5.727 * * *$ \\
\hline & $(1.253)$ & $(0.434)$ & $(0.618)$ & $(0.545)$ \\
\hline \multirow[t]{2}{*}{ AGRICULTURE } & -0.168 & -0.039 & -0.711 & 0.682 \\
\hline & $(1.220)$ & $(0.523)$ & (1.047) & $(0.520)$ \\
\hline \multirow[t]{2}{*}{ CONSTRUCTION } & 1.696 & 0.464 & 0.138 & 1.090 \\
\hline & $(1.743)$ & $(0.668)$ & (1.219) & $(0.787)$ \\
\hline \multirow[t]{2}{*}{ MANUFACTURING } & 0.253 & -0.144 & -0.561 & $0.930^{*}$ \\
\hline & $(1.254)$ & $(0.522)$ & $(1.050)$ & $(0.520)$ \\
\hline \multirow[t]{2}{*}{ TRADE } & -1.534 & 0.252 & -0.560 & $1.147^{*}$ \\
\hline & $(1.470)$ & $(0.562)$ & $(1.021)$ & $(0.623)$ \\
\hline \multirow[t]{2}{*}{ TRANSPORT } & 1.022 & 1.406 & 0.562 & $2.215^{*}$ \\
\hline & $(2.440)$ & $(0.907)$ & $(1.422)$ & (1.152) \\
\hline \multirow[t]{2}{*}{ SERVICES } & 1.122 & 0.467 & -0.325 & 1.050 \\
\hline & $(2.171)$ & $(0.754)$ & (1.304) & $(0.779)$ \\
\hline \multirow[t]{2}{*}{ PROVISION } & -0.479 & -0.698 & -1.592 & 0.107 \\
\hline & $(1.362)$ & $(0.572)$ & $(1.088)$ & $(0.609)$ \\
\hline \multirow[t]{2}{*}{ SOCIAL } & 0.692 & 0.781 & 0.031 & 1.015 \\
\hline & (1.648) & $(0.654)$ & $(1.261)$ & $(0.724)$ \\
\hline \multirow{2}{*}{ GOVERNMENT } & 0.639 & 0.028 & -0.709 & 0.591 \\
\hline & (1.573) & $(0.570)$ & (1.114) & $(0.623)$ \\
\hline \multirow[t]{2}{*}{ OTHER } & -1.987 & -0.001 & -0.516 & 1.049 \\
\hline & $(1.536)$ & $(0.636)$ & (1.112) & $(0.677)$ \\
\hline Observations & 434 & 434 & 434 & 434 \\
\hline R-squared & 0.642 & 0.807 & 0.503 & 0.626 \\
\hline
\end{tabular}




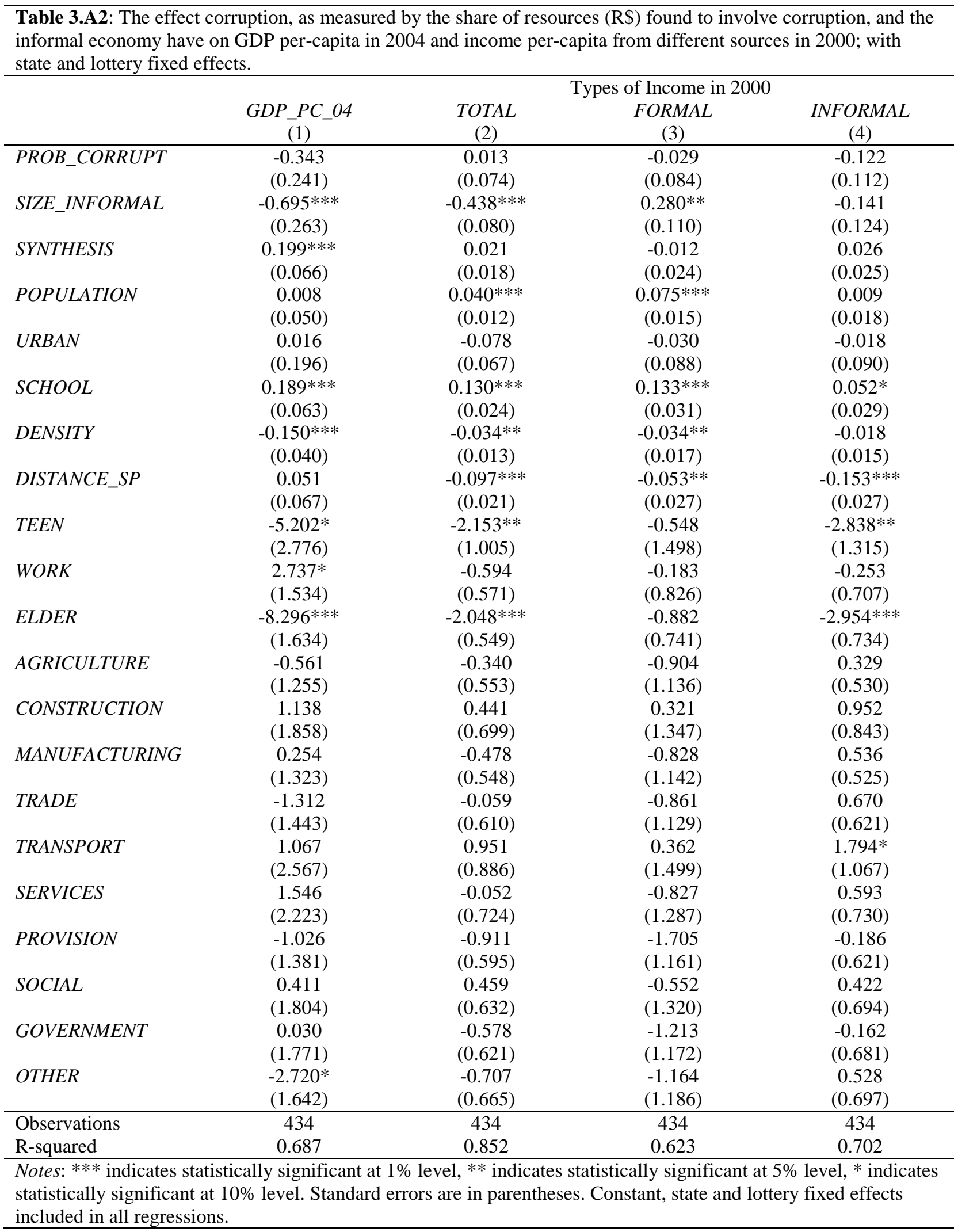




\begin{tabular}{|c|c|c|c|c|}
\hline & & & of Income ir & \\
\hline & $\underset{(1)}{G D P_{-} P C_{-} 04}$ & $\begin{array}{l}\text { TOTAL } \\
\text { (2) }\end{array}$ & $\begin{array}{c}\text { FORMAL } \\
\text { (3) }\end{array}$ & $\begin{array}{c}\text { INFORMAL } \\
\text { (4) }\end{array}$ \\
\hline PROB_CORRUPT & $-0.463 *$ & $\begin{array}{l}-0.106 \\
\end{array}$ & -0.100 & $-0.225^{*}$ \\
\hline & $(0.252)$ & $(0.096)$ & $(0.108)$ & $(0.129)$ \\
\hline MISMANAGE & 0.070 & 0.000 & 0.002 & -0.006 \\
\hline & $(0.044)$ & $(0.008)$ & $(0.012)$ & $(0.010)$ \\
\hline SIZE_INFORMAL & $-0.826 * * *$ & $-0.430 * * *$ & 0.167 & 0.020 \\
\hline & $(0.234)$ & $(0.099)$ & $(0.131)$ & $(0.136)$ \\
\hline SYNTHESIS & $0.159 * *$ & 0.035 & -0.009 & 0.043 \\
\hline & $(0.071)$ & $(0.022)$ & $(0.030)$ & $(0.030)$ \\
\hline POPULATION & 0.001 & $0.055^{* * *}$ & $0.101 * * *$ & 0.017 \\
\hline & $(0.039)$ & $(0.016)$ & $(0.021)$ & $(0.022)$ \\
\hline$U R B A N$ & -0.020 & $-0.159 * *$ & $-0.188 *$ & -0.035 \\
\hline & $(0.231)$ & $(0.076)$ & $(0.100)$ & $(0.108)$ \\
\hline SCHOOL & $0.174 * * *$ & $0.186 * * *$ & $0.147 * * *$ & $0.118 * * *$ \\
\hline & $(0.055)$ & $(0.024)$ & $(0.031)$ & $(0.030)$ \\
\hline DENSITY & $-0.123 * * *$ & $-0.059 * * *$ & $-0.056 * * *$ & $-0.050 * * *$ \\
\hline & $(0.032)$ & $(0.011)$ & $(0.014)$ & $(0.015)$ \\
\hline DISTANCE_SP & 0.007 & $-0.049 * *$ & $-0.050 * *$ & $-0.063 * *$ \\
\hline & $(0.061)$ & $(0.020)$ & $(0.024)$ & $(0.026)$ \\
\hline TEEN & -3.515 & $-4.383 * * *$ & -2.458 & $-5.111 * * *$ \\
\hline & (2.642) & $(1.061)$ & (1.647) & $(1.266)$ \\
\hline WORK & $4.663 * * *$ & $-1.608 * * *$ & -0.536 & $-1.315^{*}$ \\
\hline & $(1.359)$ & $(0.561)$ & $(0.861)$ & $(0.720)$ \\
\hline ELDER & $-5.494 * * *$ & $-4.168 * * *$ & $-2.943 * * *$ & $-5.727 * * *$ \\
\hline & $(1.331)$ & $(0.550)$ & $(0.783)$ & $(0.690)$ \\
\hline AGRICULTURE & -1.019 & -0.578 & $-2.612 * *$ & 1.173 \\
\hline & (2.018) & $(0.898)$ & $(1.022)$ & $(0.742)$ \\
\hline CONSTRUCTION & -0.733 & -0.197 & -2.119 & $1.960^{*}$ \\
\hline & (2.732) & $(1.141)$ & $(1.295)$ & $(1.131)$ \\
\hline MANUFACTURING & -0.679 & -0.741 & $-2.478 * *$ & $1.370^{*}$ \\
\hline & (2.066) & $(0.893)$ & $(1.027)$ & $(0.725)$ \\
\hline TRADE & -1.492 & -0.263 & $-2.227 * *$ & $1.620^{* *}$ \\
\hline & (2.133) & $(0.901)$ & $(1.027)$ & $(0.822)$ \\
\hline TRANSPORT & -1.510 & 0.946 & -1.741 & $3.099 * *$ \\
\hline & $(3.152)$ & $(1.275)$ & $(1.480)$ & $(1.445)$ \\
\hline SERVICES & 1.960 & -0.150 & $-2.506 *$ & 1.646 \\
\hline & (3.855) & (1.209) & (1.430) & $(1.230)$ \\
\hline PROVISION & -1.281 & -1.304 & $-3.576 * * *$ & 0.443 \\
\hline & (2.144) & $(0.946)$ & $(1.100)$ & $(0.866)$ \\
\hline SOCIAL & 0.216 & 0.180 & -1.823 & 1.274 \\
\hline & $(2.530)$ & (1.065) & $(1.284)$ & $(0.988)$ \\
\hline GOVERNMENT & -0.351 & -0.430 & $-2.704 * *$ & 1.138 \\
\hline & $(2.268)$ & $(0.926)$ & (1.110) & $(0.789)$ \\
\hline OTHER & -2.299 & -0.460 & $-2.290 * *$ & $1.466^{*}$ \\
\hline & $(2.310)$ & $(1.016)$ & $(1.163)$ & $(0.871)$ \\
\hline Observations & 331 & 331 & 331 & 331 \\
\hline R-squared & 0.662 & 0.800 & 0.505 & 0.619 \\
\hline
\end{tabular}




\begin{tabular}{|c|c|c|c|c|}
\hline & \multirow[b]{2}{*}{$\underset{(1)}{G D P_{-} P C_{-} 04}$} & \multicolumn{3}{|c|}{ Types of Income in 2000} \\
\hline & & $\begin{array}{l}\text { TOTAL } \\
\text { (2) }\end{array}$ & $\begin{array}{l}\text { FORMAL } \\
\text { (3) }\end{array}$ & $\begin{array}{c}\text { INFORMAL } \\
\text { (4) }\end{array}$ \\
\hline PROB_CORRUPT & $\begin{array}{l}-0.482 \\
(0.304)\end{array}$ & $\begin{array}{c}0.013 \\
(0.091)\end{array}$ & $\begin{array}{l}-0.070 \\
(0.107)\end{array}$ & $\begin{array}{l}-0.065 \\
(0.131)\end{array}$ \\
\hline MISMANAGE & $\begin{array}{c}0.044 \\
(0.050)\end{array}$ & $\begin{array}{c}0.002 \\
(0.010)\end{array}$ & $\begin{array}{c}0.003 \\
(0.013)\end{array}$ & $\begin{array}{l}-0.005 \\
(0.012)\end{array}$ \\
\hline SIZE_INFORMAL & $\begin{array}{l}-0.442 \\
(0.290)\end{array}$ & $\begin{array}{c}-0.438 * * * \\
(0.105)\end{array}$ & $\begin{array}{c}0.294 * * \\
(0.131)\end{array}$ & $\begin{array}{l}-0.138 \\
(0.161)\end{array}$ \\
\hline SYNTHESIS & $\begin{array}{l}0.149^{*} \\
(0.079)\end{array}$ & $\begin{array}{c}0.033 \\
(0.025)\end{array}$ & $\begin{array}{l}-0.036 \\
(0.031)\end{array}$ & $\begin{array}{l}0.060^{*} \\
(0.033)\end{array}$ \\
\hline POPULATION & $\begin{array}{c}0.024 \\
(0.049)\end{array}$ & $\begin{array}{c}0.048 * * * \\
(0.016)\end{array}$ & $\begin{array}{c}0.092 * * * \\
(0.021)\end{array}$ & $\begin{array}{c}0.007 \\
(0.022)\end{array}$ \\
\hline$U R B A N$ & $\begin{array}{c}0.038 \\
(0.236)\end{array}$ & $\begin{array}{l}-0.106 \\
(0.085)\end{array}$ & $\begin{array}{l}-0.101 \\
(0.105)\end{array}$ & $\begin{array}{l}-0.020 \\
(0.116)\end{array}$ \\
\hline SCHOOL & $\begin{array}{c}0.208 * * * \\
(0.076)\end{array}$ & $\begin{array}{c}0.133 * * * \\
(0.029)\end{array}$ & $\begin{array}{c}0.135 * * * \\
(0.039)\end{array}$ & $\begin{array}{c}0.048 \\
(0.035)\end{array}$ \\
\hline DENSITY & $\begin{array}{c}-0.150 * * * \\
(0.047)\end{array}$ & $\begin{array}{l}-0.032^{*} \\
(0.016)\end{array}$ & $\begin{array}{l}-0.029 \\
(0.020)\end{array}$ & $\begin{array}{l}-0.020 \\
(0.019)\end{array}$ \\
\hline DISTANCE_SP & $\begin{array}{c}0.066 \\
(0.092)\end{array}$ & $\begin{array}{c}-0.092 * * * \\
(0.030)\end{array}$ & $\begin{array}{l}-0.060 \\
(0.037)\end{array}$ & $\begin{array}{c}-0.152 * * * \\
(0.037)\end{array}$ \\
\hline TEEN & $\begin{array}{c}-7.578 * * \\
(3.393)\end{array}$ & $\begin{array}{c}-2.972 * * \\
(1.284)\end{array}$ & $\begin{array}{l}-1.808 \\
(1.939)\end{array}$ & $\begin{array}{l}-2.693 \\
(1.693)\end{array}$ \\
\hline WORK & $\begin{array}{l}1.789 \\
(1.774)\end{array}$ & $\begin{array}{l}-0.792 \\
(0.694)\end{array}$ & $\begin{array}{l}-0.401 \\
(1.014)\end{array}$ & $\begin{array}{l}-0.167 \\
(0.831)\end{array}$ \\
\hline ELDER & $\begin{array}{c}-8.767 * * * \\
(2.126)\end{array}$ & $\begin{array}{c}-2.399 * * * \\
(0.703)\end{array}$ & $\begin{array}{l}-1.590 \\
(0.969)\end{array}$ & $\begin{array}{c}-2.931 * * * \\
(0.923)\end{array}$ \\
\hline AGRICULTURE & $\begin{array}{l}-2.058 \\
(2.490)\end{array}$ & $\begin{array}{l}-0.732 \\
(0.969)\end{array}$ & $\begin{array}{c}-2.833 * * \\
(1.165)\end{array}$ & $\begin{array}{c}0.888 \\
(0.696)\end{array}$ \\
\hline CONSTRUCTION & $\begin{array}{l}-2.478 \\
(3.343)\end{array}$ & $\begin{array}{c}0.073 \\
(1.229)\end{array}$ & $\begin{array}{l}-2.214 \\
(1.465)\end{array}$ & $\begin{array}{l}2.376^{* * *} \\
(1.119)\end{array}$ \\
\hline MANUFACTURING & $\begin{array}{l}-1.635 \\
(2.549)\end{array}$ & $\begin{array}{l}-0.926 \\
(0.967)\end{array}$ & $\begin{array}{c}-2.865^{* *} \\
(1.167)\end{array}$ & $\begin{array}{l}1.094 \\
(0.676)\end{array}$ \\
\hline TRADE & $\begin{array}{l}-1.978 \\
(2.476)\end{array}$ & $\begin{array}{l}-0.538 \\
(0.988)\end{array}$ & $\begin{array}{c}-2.689 * * \\
(1.171)\end{array}$ & $\begin{array}{l}1.116 \\
(0.776)\end{array}$ \\
\hline TRANSPORT & $\begin{array}{l}-2.292 \\
(3.659)\end{array}$ & $\begin{array}{c}0.420 \\
(1.299)\end{array}$ & $\begin{array}{l}-2.228 \\
(1.656)\end{array}$ & $\begin{array}{l}2.234^{*} \\
(1.313)\end{array}$ \\
\hline SERVICES & $\begin{array}{c}2.085 \\
(4.223)\end{array}$ & $\begin{array}{l}-0.647 \\
(1.178)\end{array}$ & $\begin{array}{c}-2.988 * * \\
(1.450)\end{array}$ & $\begin{array}{c}1.125 \\
(1.093)\end{array}$ \\
\hline PROVISION & $\begin{array}{l}-2.253 \\
(2.538)\end{array}$ & $\begin{array}{l}-1.465 \\
(1.008)\end{array}$ & $\begin{array}{c}-3.794 * * * \\
(1.206)\end{array}$ & $\begin{array}{c}0.159 \\
(0.808)\end{array}$ \\
\hline SOCIAL & $\begin{array}{l}-0.508 \\
(3.056)\end{array}$ & $\begin{array}{c}0.062 \\
(1.094)\end{array}$ & $\begin{array}{c}-2.387 * \\
(1.359)\end{array}$ & $\begin{array}{c}0.884 \\
(0.884)\end{array}$ \\
\hline GOVERNMENT & $\begin{array}{l}-1.036 \\
(2.773)\end{array}$ & $\begin{array}{l}-1.092 \\
(1.012)\end{array}$ & $\begin{array}{c}-3.222 * * * \\
(1.237)\end{array}$ & $\begin{array}{c}0.104 \\
(0.800)\end{array}$ \\
\hline OTHER & $\begin{array}{l}-3.220 \\
(2.753) \\
\end{array}$ & $\begin{array}{l}-1.057 \\
(1.070) \\
\end{array}$ & $\begin{array}{c}-3.005^{* *} \\
(1.269) \\
\end{array}$ & $\begin{array}{c}0.942 \\
(0.847) \\
\end{array}$ \\
\hline Observations & 331 & 331 & 331 & 331 \\
\hline R-squared & 0.705 & 0.848 & 0.630 & 0.704 \\
\hline
\end{tabular}




\begin{tabular}{|c|c|c|c|c|}
\hline & \multirow[b]{2}{*}{$\begin{array}{c}G D P \_P C \_04 \\
(1)\end{array}$} & \multicolumn{3}{|c|}{ Types of Income in 2000} \\
\hline & & $\begin{array}{l}\text { TOTAL } \\
(2)\end{array}$ & $\begin{array}{c}\text { FORMAL } \\
(3) \\
\end{array}$ & $\begin{array}{c}\text { INFORMAL } \\
\text { (4) }\end{array}$ \\
\hline PROB_CORRUPT_2 & $\begin{array}{c}0.130 \\
(0.474)\end{array}$ & $\begin{array}{l}-0.181 \\
(0.182)\end{array}$ & $\begin{array}{l}-0.240 \\
(0.229)\end{array}$ & $\begin{array}{l}-0.193 \\
(0.246)\end{array}$ \\
\hline SIZE_INFORMAL & $\begin{array}{c}-0.868 * * * \\
(0.201)\end{array}$ & $\begin{array}{c}-0.391 * * * \\
(0.078)\end{array}$ & $\begin{array}{c}0.227 * * \\
(0.108)\end{array}$ & $\begin{array}{c}0.016 \\
(0.105)\end{array}$ \\
\hline SYNTHESIS & $\begin{array}{c}0.180 * * * \\
(0.063)\end{array}$ & $\begin{array}{c}0.026 \\
(0.018)\end{array}$ & $\begin{array}{c}0.006 \\
(0.025)\end{array}$ & $\begin{array}{c}0.021 \\
(0.025)\end{array}$ \\
\hline POPULATION & $\begin{array}{c}0.015 \\
(0.041)\end{array}$ & $\begin{array}{c}0.048 * * * \\
(0.013)\end{array}$ & $\begin{array}{c}0.086^{* * * *} \\
(0.017)\end{array}$ & $\begin{array}{c}0.017 \\
(0.019)\end{array}$ \\
\hline URBAN & $\begin{array}{l}-0.044 \\
(0.206)\end{array}$ & $\begin{array}{c}-0.144 * * \\
(0.066)\end{array}$ & $\begin{array}{l}-0.113 \\
(0.091)\end{array}$ & $\begin{array}{l}-0.084 \\
(0.088)\end{array}$ \\
\hline SCHOOL & $\begin{array}{c}0.168 * * * \\
(0.054)\end{array}$ & $\begin{array}{c}0.195 * * * \\
(0.020)\end{array}$ & $\begin{array}{c}0.169 * * * \\
(0.026)\end{array}$ & $\begin{array}{c}0.126 * * * \\
(0.025)\end{array}$ \\
\hline DENSITY & $\begin{array}{c}-0.117 * * * \\
(0.029)\end{array}$ & $\begin{array}{c}-0.058 * * * \\
(0.010)\end{array}$ & $\begin{array}{c}-0.056 * * * \\
(0.012)\end{array}$ & $\begin{array}{c}-0.048 * * * \\
(0.013)\end{array}$ \\
\hline DISTANCE_SP & $\begin{array}{c}0.029 \\
(0.049)\end{array}$ & $\begin{array}{c}-0.047 * * * \\
(0.016)\end{array}$ & $\begin{array}{c}-0.040 * * \\
(0.020)\end{array}$ & $\begin{array}{c}-0.062^{* * * *} \\
(0.021)\end{array}$ \\
\hline TEEN & $\begin{array}{l}-3.816 \\
(2.401)\end{array}$ & $\begin{array}{c}-3.932 * * * \\
(0.890)\end{array}$ & $\begin{array}{l}-1.973 \\
(1.363)\end{array}$ & $\begin{array}{c}-5.290 * * * \\
(1.068)\end{array}$ \\
\hline WORK & $\begin{array}{c}4.554 * * * \\
(1.246)\end{array}$ & $\begin{array}{c}-1.615^{* * * *} \\
(0.483)\end{array}$ & $\begin{array}{l}-0.907 \\
(0.724)\end{array}$ & $\begin{array}{c}-1.272 * * \\
(0.606)\end{array}$ \\
\hline ELDER & $\begin{array}{c}-5.980 * * * \\
(1.242)\end{array}$ & $\begin{array}{c}-4.015^{* * * *} \\
(0.428)\end{array}$ & $\begin{array}{c}-2.645^{* * * *} \\
(0.611)\end{array}$ & $\begin{array}{c}-5.771 * * * \\
(0.542)\end{array}$ \\
\hline AGRICULTURE & $\begin{array}{c}-0.244 \\
(1.217)\end{array}$ & $\begin{array}{l}-0.057 \\
(0.536)\end{array}$ & $\begin{array}{l}-0.734 \\
(1.054)\end{array}$ & $\begin{array}{c}0.635 \\
(0.520)\end{array}$ \\
\hline CONSTRUCTION & $\begin{array}{l}1.256 \\
(1.654)\end{array}$ & $\begin{array}{c}0.394 \\
(0.657)\end{array}$ & $\begin{array}{c}0.055 \\
(1.203)\end{array}$ & $\begin{array}{c}0.864 \\
(0.823)\end{array}$ \\
\hline MANUFACTURING & $\begin{array}{c}0.190 \\
(1.252)\end{array}$ & $\begin{array}{l}-0.167 \\
(0.534)\end{array}$ & $\begin{array}{l}-0.591 \\
(1.056)\end{array}$ & $\begin{array}{l}0.880^{*} \\
(0.519)\end{array}$ \\
\hline TRADE & $\begin{array}{l}-1.530 \\
(1.477)\end{array}$ & $\begin{array}{c}0.262 \\
(0.578)\end{array}$ & $\begin{array}{l}-0.547 \\
(1.034)\end{array}$ & $\begin{array}{l}1.161^{*} \\
(0.625)\end{array}$ \\
\hline TRANSPORT & $\begin{array}{c}0.888 \\
(2.440)\end{array}$ & $\begin{array}{l}1.430 \\
(0.911)\end{array}$ & $\begin{array}{c}0.596 \\
(1.433)\end{array}$ & $\begin{array}{l}2.204^{*} \\
(1.137)\end{array}$ \\
\hline SERVICES & $\begin{array}{l}1.086 \\
(2.166)\end{array}$ & $\begin{array}{c}0.472 \\
(0.776)\end{array}$ & $\begin{array}{l}-0.317 \\
(1.327)\end{array}$ & $\begin{array}{c}1.045 \\
(0.786)\end{array}$ \\
\hline PROVISION & $\begin{array}{l}-0.521 \\
(1.366)\end{array}$ & $\begin{array}{l}-0.715 \\
(0.585)\end{array}$ & $\begin{array}{l}-1.614 \\
(1.096)\end{array}$ & $\begin{array}{c}0.071 \\
(0.612)\end{array}$ \\
\hline SOCIAL & $\begin{array}{c}0.661 \\
(1.653)\end{array}$ & $\begin{array}{c}0.777 \\
(0.668)\end{array}$ & $\begin{array}{c}0.026 \\
(1.270)\end{array}$ & $\begin{array}{l}1.000 \\
(0.724)\end{array}$ \\
\hline GOVERNMENT & $\begin{array}{c}0.700 \\
(1.575)\end{array}$ & $\begin{array}{l}-0.006 \\
(0.582)\end{array}$ & $\begin{array}{l}-0.756 \\
(1.120)\end{array}$ & $\begin{array}{c}0.566 \\
(0.628)\end{array}$ \\
\hline OTHER & $\begin{array}{l}-2.081 \\
(1.534)\end{array}$ & $\begin{array}{c}-0.007 \\
(0.648)\end{array}$ & $\begin{array}{c}-0.522 \\
(1.121) \\
\end{array}$ & $\begin{array}{c}1.012 \\
(0.671)\end{array}$ \\
\hline Observations & 434 & 434 & 434 & 434 \\
\hline R-squared & 0.639 & 0.807 & 0.505 & 0.624 \\
\hline
\end{tabular}




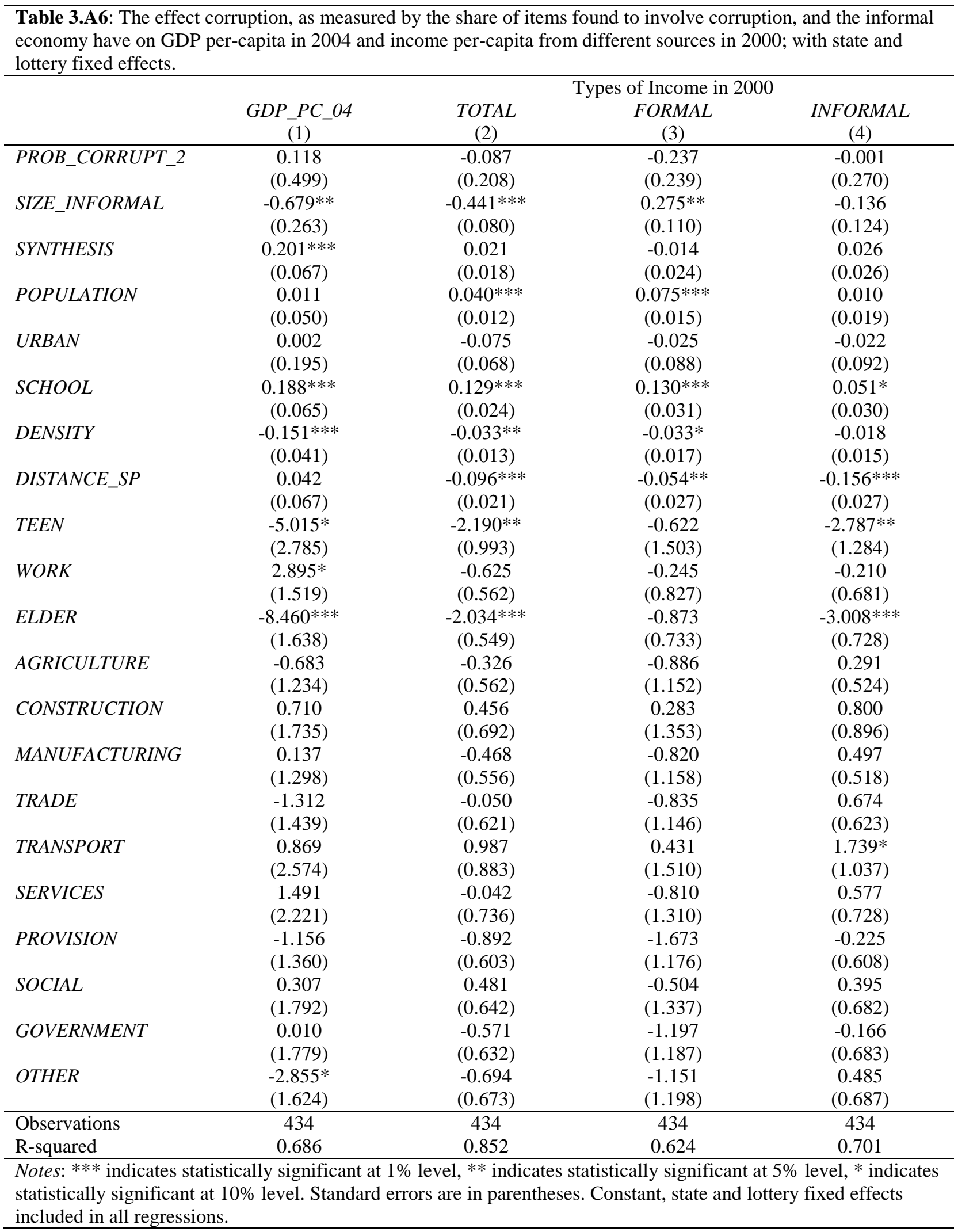




\begin{tabular}{|c|c|c|c|c|}
\hline & \multirow[b]{2}{*}{$\underset{(1)}{G D P_{-} P C_{-} 04}$} & \multicolumn{3}{|c|}{ Types of Income in 2000} \\
\hline & & $\begin{array}{l}\text { TOTAL } \\
\text { (2) }\end{array}$ & $\begin{array}{l}\text { FORMAL } \\
\text { (3) }\end{array}$ & $\begin{array}{c}\text { INFORMAL } \\
\text { (4) }\end{array}$ \\
\hline PROB_CORRUPT_2 & -0.067 & -0.236 & -0.357 & 0.026 \\
\hline MISM $A N A C E$ & $(0.678)$ & $(0.263)$ & $(0.325)$ & $(0.343)$ \\
\hline MISMANAGE & $\begin{array}{c}0.067 \\
(0.049)\end{array}$ & $\begin{array}{c}0.004 \\
(0.009)\end{array}$ & $\begin{array}{c}0.008 \\
(0.013)\end{array}$ & $\begin{array}{l}-0.009 \\
(0.011)\end{array}$ \\
\hline SIZE_INFORMAL & $\begin{array}{c}-0.801 * * * \\
(0.232)\end{array}$ & $\begin{array}{c}-0.432 * * * \\
(0.100)\end{array}$ & $\begin{array}{c}0.159 \\
(0.133)\end{array}$ & $\begin{array}{c}0.034 \\
(0.139)\end{array}$ \\
\hline SYNTHESIS & $\begin{array}{c}0.158 * * \\
(0.071)\end{array}$ & $\begin{array}{c}0.033 \\
(0.023)\end{array}$ & $\begin{array}{l}-0.013 \\
(0.031)\end{array}$ & $\begin{array}{c}0.043 \\
(0.031)\end{array}$ \\
\hline POPULATION & $\begin{array}{c}0.008 \\
(0.040)\end{array}$ & $\begin{array}{c}0.056 * * * \\
(0.016)\end{array}$ & $\begin{array}{c}0.101 * * * \\
(0.021)\end{array}$ & $\begin{array}{c}0.020 \\
(0.023)\end{array}$ \\
\hline$U R B A N$ & $\begin{array}{l}-0.062 \\
(0.228)\end{array}$ & $\begin{array}{c}-0.163 * * \\
(0.076)\end{array}$ & $\begin{array}{l}-0.188^{*} \\
(0.101)\end{array}$ & $\begin{array}{l}-0.057 \\
(0.109)\end{array}$ \\
\hline SCHOOL & $\begin{array}{c}0.181 * * * \\
(0.057)\end{array}$ & $\begin{array}{c}0.184 * * * \\
(0.024)\end{array}$ & $\begin{array}{c}0.144 * * * \\
(0.032)\end{array}$ & $\begin{array}{c}0.123 * * * \\
(0.031)\end{array}$ \\
\hline DENSITY & $\begin{array}{c}-0.126^{* * * *} \\
(0.033)\end{array}$ & $\begin{array}{c}-0.059 * * * \\
(0.011)\end{array}$ & $\begin{array}{c}-0.056^{* * * *} \\
(0.014)\end{array}$ & $\begin{array}{c}-0.051 * * * \\
(0.015)\end{array}$ \\
\hline DISTANCE_SP & $\begin{array}{c}0.007 \\
(0.060)\end{array}$ & $\begin{array}{c}-0.051 * * \\
(0.020)\end{array}$ & $\begin{array}{c}-0.053 * * \\
(0.024)\end{array}$ & $\begin{array}{c}-0.062 * * \\
(0.026)\end{array}$ \\
\hline TEEN & $\begin{array}{l}-3.888 \\
(2.659)\end{array}$ & $\begin{array}{c}-4.360 * * * \\
(1.068)\end{array}$ & $\begin{array}{l}-2.370 \\
(1.647)\end{array}$ & $\begin{array}{c}-5.320 * * * \\
(1.308)\end{array}$ \\
\hline WORK & $\begin{array}{c}4.621 * * * \\
(1.374)\end{array}$ & $\begin{array}{c}-1.616^{* * *} \\
(0.559)\end{array}$ & $\begin{array}{l}-0.541 \\
(0.858)\end{array}$ & $\begin{array}{c}-1.336^{*} \\
(0.724)\end{array}$ \\
\hline ELDER & $\begin{array}{c}-5.623 * * * \\
(1.324)\end{array}$ & $\begin{array}{c}-4.195 * * * \\
(0.545)\end{array}$ & $\begin{array}{c}-2.967 * * * \\
(0.777)\end{array}$ & $\begin{array}{c}-5.790 * * * \\
(0.686)\end{array}$ \\
\hline AGRICULTURE & $\begin{array}{l}-1.148 \\
(1.986)\end{array}$ & $\begin{array}{l}-0.610 \\
(0.918)\end{array}$ & $\begin{array}{c}-2.643 * * \\
(1.055)\end{array}$ & $\begin{array}{l}1.111 \\
(0.724)\end{array}$ \\
\hline CONSTRUCTION & $\begin{array}{l}-0.913 \\
(2.718)\end{array}$ & $\begin{array}{l}-0.272 \\
(1.153)\end{array}$ & $\begin{array}{l}-2.211 * \\
(1.315)\end{array}$ & $\begin{array}{l}1.882^{*} \\
(1.119)\end{array}$ \\
\hline MANUFACTURING & $\begin{array}{l}-0.814 \\
(2.032)\end{array}$ & $\begin{array}{l}-0.783 \\
(0.913)\end{array}$ & $\begin{array}{c}-2.525^{* *} \\
(1.056)\end{array}$ & $\begin{array}{l}1.307^{*} \\
(0.709)\end{array}$ \\
\hline TRADE & $\begin{array}{l}-1.509 \\
(2.116)\end{array}$ & $\begin{array}{l}-0.259 \\
(0.923)\end{array}$ & $\begin{array}{c}-2.219 * * \\
(1.064)\end{array}$ & $\begin{array}{l}1.610 * * \\
(0.817)\end{array}$ \\
\hline TRANSPORT & $\begin{array}{l}-1.653 \\
(3.148)\end{array}$ & $\begin{array}{c}0.937 \\
(1.295)\end{array}$ & $\begin{array}{l}-1.734 \\
(1.512)\end{array}$ & $\begin{array}{l}3.023 * * \\
(1.422)\end{array}$ \\
\hline SERVICES & $\begin{array}{c}1.761 \\
(3.831)\end{array}$ & $\begin{array}{l}-0.184 \\
(1.231)\end{array}$ & $\begin{array}{l}-2.531 * \\
(1.467)\end{array}$ & $\begin{array}{l}1.547 \\
(1.208)\end{array}$ \\
\hline PROVISION & $\begin{array}{l}-1.471 \\
(2.115)\end{array}$ & $\begin{array}{l}-1.339 \\
(0.965)\end{array}$ & $\begin{array}{c}-3.604 * * * \\
(1.128)\end{array}$ & $\begin{array}{c}0.348 \\
(0.847)\end{array}$ \\
\hline SOCIAL & $\begin{array}{c}0.132 \\
(2.500)\end{array}$ & $\begin{array}{c}0.175 \\
(1.086)\end{array}$ & $\begin{array}{l}-1.819 \\
(1.318)\end{array}$ & $\begin{array}{l}1.229 \\
(0.963)\end{array}$ \\
\hline GOVERNMENT & $\begin{array}{l}-0.415 \\
(2.234)\end{array}$ & $\begin{array}{l}-0.469 \\
(0.949)\end{array}$ & $\begin{array}{c}-2.756 * * \\
(1.138)\end{array}$ & $\begin{array}{l}1.114 \\
(0.788)\end{array}$ \\
\hline OTHER & $\begin{array}{l}-2.376 \\
(2.294)\end{array}$ & $\begin{array}{c}-0.492 \\
(1.038)\end{array}$ & $\begin{array}{l}-2.328^{*} \\
(1.199) \\
\end{array}$ & $\begin{array}{l}1.432^{*} \\
(0.853)\end{array}$ \\
\hline Observations & 331 & 331 & 331 & 331 \\
\hline R-squared & 0.659 & 0.800 & 0.506 & 0.615 \\
\hline
\end{tabular}




\begin{tabular}{|c|c|c|c|c|}
\hline & \multirow[b]{2}{*}{$\underset{(1)}{G D P \_P C \_04}$} & \multicolumn{3}{|c|}{ Types of Income in 2000} \\
\hline & & $\begin{array}{l}\text { TOTAL } \\
\text { (2) }\end{array}$ & $\begin{array}{c}\text { FORMAL } \\
\text { (3) }\end{array}$ & $\begin{array}{c}\text { INFORMAL } \\
\text { (4) }\end{array}$ \\
\hline \multirow[t]{2}{*}{$P R O B \_C O R R U P T \_2$} & 0.359 & -0.010 & -0.254 & 0.242 \\
\hline & $(0.718)$ & $(0.262)$ & $(0.331)$ & $(0.327)$ \\
\hline MISMANAGE & 0.034 & 0.002 & 0.006 & -0.009 \\
\hline \multirow[t]{2}{*}{ SIZE_INFORMAL } & $\begin{array}{l}(0.054) \\
-0.403\end{array}$ & $\begin{array}{c}(0.009) \\
-0.440 * * *\end{array}$ & $\begin{array}{c}(0.014) \\
0.285^{* *}\end{array}$ & $\begin{array}{l}(0.012) \\
-0.123\end{array}$ \\
\hline & $(0.287)$ & $(0.107)$ & $(0.133)$ & $(0.164)$ \\
\hline SYNTHESIS & $\begin{array}{l}0.149 * \\
(0.079)\end{array}$ & $\begin{array}{c}0.033 \\
(0.025)\end{array}$ & $\begin{array}{l}-0.037 \\
(0.031)\end{array}$ & $\begin{array}{l}0.060^{*} \\
(0.034)\end{array}$ \\
\hline POPULATION & $\begin{array}{c}0.031 \\
(0.050)\end{array}$ & $\begin{array}{c}0.048 * * * \\
(0.016)\end{array}$ & $\begin{array}{c}0.092 * * * \\
(0.020)\end{array}$ & $\begin{array}{c}0.009 \\
(0.023)\end{array}$ \\
\hline$U R B A N$ & $\begin{array}{l}-0.006 \\
(0.232)\end{array}$ & $\begin{array}{l}-0.104 \\
(0.085)\end{array}$ & $\begin{array}{l}-0.102 \\
(0.105)\end{array}$ & $\begin{array}{l}-0.030 \\
(0.118)\end{array}$ \\
\hline SCHOOL & $\begin{array}{c}0.210 * * * \\
(0.077)\end{array}$ & $\begin{array}{c}0.133 * * * \\
(0.030)\end{array}$ & $\begin{array}{c}0.134 * * * \\
(0.039)\end{array}$ & $\begin{array}{c}0.049 \\
(0.035)\end{array}$ \\
\hline DENSITY & $\begin{array}{c}-0.155^{* * * *} \\
(0.048)\end{array}$ & $\begin{array}{l}-0.032^{*} \\
(0.016)\end{array}$ & $\begin{array}{l}-0.029 \\
(0.019)\end{array}$ & $\begin{array}{l}-0.021 \\
(0.019)\end{array}$ \\
\hline$D I S T A N C E \_S P$ & $\begin{array}{c}0.047 \\
(0.092)\end{array}$ & $\begin{array}{c}-0.092 * * * \\
(0.030)\end{array}$ & $\begin{array}{l}-0.060 \\
(0.037)\end{array}$ & $\begin{array}{c}-0.156 * * * \\
(0.036)\end{array}$ \\
\hline TEEN & $\begin{array}{c}-7.162 * * \\
(3.446)\end{array}$ & $\begin{array}{c}-2.983 * * \\
(1.262)\end{array}$ & $\begin{array}{l}-1.905 \\
(1.937)\end{array}$ & $\begin{array}{l}-2.538 \\
(1.645)\end{array}$ \\
\hline WORK & $\begin{array}{c}2.156 \\
(1.769)\end{array}$ & $\begin{array}{l}-0.802 \\
(0.684)\end{array}$ & $\begin{array}{l}-0.449 \\
(1.016)\end{array}$ & $\begin{array}{l}-0.054 \\
(0.802)\end{array}$ \\
\hline ELDER & $\begin{array}{c}-8.819 * * * \\
(2.120)\end{array}$ & $\begin{array}{c}-2.398 * * * \\
(0.706)\end{array}$ & $\begin{array}{l}-1.619^{*} \\
(0.963)\end{array}$ & $\begin{array}{c}-2.925 * * * \\
(0.919)\end{array}$ \\
\hline AGRICULTURE & $\begin{array}{l}-2.266 \\
(2.384)\end{array}$ & $\begin{array}{l}-0.727 \\
(0.970)\end{array}$ & $\begin{array}{c}-2.833 * * \\
(1.193)\end{array}$ & $\begin{array}{c}0.841 \\
(0.670)\end{array}$ \\
\hline CONSTRUCTION & $\begin{array}{l}-2.603 \\
(3.241)\end{array}$ & $\begin{array}{l}0.076 \\
(1.230)\end{array}$ & $\begin{array}{l}-2.253 \\
(1.491)\end{array}$ & $\begin{array}{c}2.373^{* *} \\
(1.105)\end{array}$ \\
\hline MANUFACTURING & $\begin{array}{l}-1.798 \\
(2.447)\end{array}$ & $\begin{array}{l}-0.921 \\
(0.968)\end{array}$ & $\begin{array}{c}-2.886 * * \\
(1.194)\end{array}$ & $\begin{array}{l}1.070 \\
(0.652)\end{array}$ \\
\hline TRADE & $\begin{array}{l}-1.992 \\
(2.399)\end{array}$ & $\begin{array}{l}-0.537 \\
(0.990)\end{array}$ & $\begin{array}{c}-2.695 * * \\
(1.196)\end{array}$ & $\begin{array}{c}1.117 \\
(0.763)\end{array}$ \\
\hline TRANSPORT & $\begin{array}{l}-2.770 \\
(3.605)\end{array}$ & $\begin{array}{c}0.433 \\
(1.289)\end{array}$ & $\begin{array}{l}-2.199 \\
(1.675)\end{array}$ & $\begin{array}{l}2.107^{*} \\
(1.273)\end{array}$ \\
\hline SERVICES & $\begin{array}{l}1.865 \\
(4.172)\end{array}$ & $\begin{array}{l}-0.641 \\
(1.180)\end{array}$ & $\begin{array}{c}-3.029 * * \\
(1.469)\end{array}$ & $\begin{array}{l}1.101 \\
(1.081)\end{array}$ \\
\hline PROVISION & $\begin{array}{l}-2.584 \\
(2.441)\end{array}$ & $\begin{array}{l}-1.456 \\
(1.007)\end{array}$ & $\begin{array}{c}-3.787 * * * \\
(1.234)\end{array}$ & $\begin{array}{c}0.080 \\
(0.778)\end{array}$ \\
\hline SOCIAL & $\begin{array}{l}-0.689 \\
(2.963)\end{array}$ & $\begin{array}{c}0.067 \\
(1.095)\end{array}$ & $\begin{array}{l}-2.360 * \\
(1.390)\end{array}$ & $\begin{array}{c}0.826 \\
(0.855)\end{array}$ \\
\hline GOVERNMENT & $\begin{array}{l}-1.297 \\
(2.694)\end{array}$ & $\begin{array}{l}-1.084 \\
(1.013)\end{array}$ & $\begin{array}{c}-3.235^{* *} \\
(1.260)\end{array}$ & $\begin{array}{c}0.052 \\
(0.791)\end{array}$ \\
\hline OTHER & $\begin{array}{l}-3.379 \\
(2.657) \\
\end{array}$ & $\begin{array}{l}-1.052 \\
(1.071) \\
\end{array}$ & $\begin{array}{c}-3.019 * * \\
(1.295) \\
\end{array}$ & $\begin{array}{c}0.915 \\
(0.821) \\
\end{array}$ \\
\hline Observations & 331 & 331 & 331 & 331 \\
\hline R-squared & 0.702 & 0.848 & 0.630 & 0.704 \\
\hline
\end{tabular}




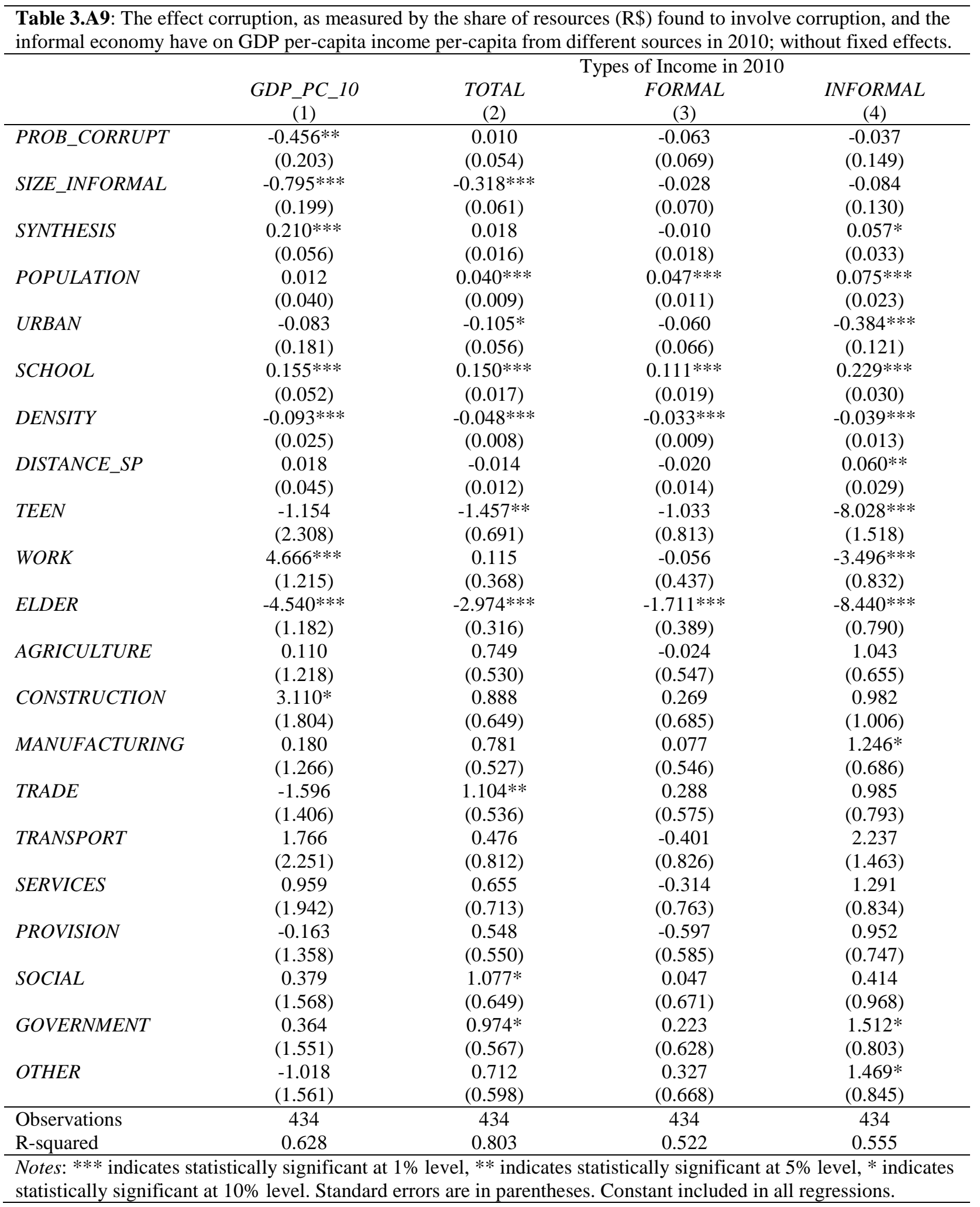




\begin{tabular}{|c|c|c|c|c|}
\hline & & & of Income in & \\
\hline & $\begin{array}{c}G D P \_P C_{-} 10 \\
(1)\end{array}$ & $\begin{array}{l}\text { TOTAL } \\
\text { (2) }\end{array}$ & $\begin{array}{c}\text { FORMAL } \\
\text { (3) }\end{array}$ & $\begin{array}{c}\text { INFORMAL } \\
\text { (4) }\end{array}$ \\
\hline PROB_CORRUPT & -0.299 & -0.002 & -0.085 & 0.133 \\
\hline & $(0.207)$ & $(0.051)$ & $(0.065)$ & $(0.104)$ \\
\hline SIZE_INFORMAL & $\begin{array}{c}-0.609 * * \\
(0.255)\end{array}$ & $\begin{array}{c}-0.260 * * * \\
(0.065)\end{array}$ & $\begin{array}{c}0.095 \\
(0.074)\end{array}$ & $\begin{array}{c}-0.251 * * \\
(0.124)\end{array}$ \\
\hline SYNTHESIS & $\begin{array}{c}0.250 * * * \\
(0.058)\end{array}$ & $\begin{array}{c}0.020 \\
(0.015)\end{array}$ & $\begin{array}{l}-0.006 \\
(0.018)\end{array}$ & $\begin{array}{c}0.037 \\
(0.026)\end{array}$ \\
\hline POPULATION & $\begin{array}{l}-0.004 \\
(0.047)\end{array}$ & $\begin{array}{c}0.045 * * * \\
(0.009)\end{array}$ & $\begin{array}{c}0.050 * * * \\
(0.011)\end{array}$ & $\begin{array}{c}0.053 * * * \\
(0.016)\end{array}$ \\
\hline$U R B A N$ & $\begin{array}{l}-0.081 \\
(0.172)\end{array}$ & $\begin{array}{l}-0.089 \\
(0.056)\end{array}$ & $\begin{array}{l}-0.034 \\
(0.069)\end{array}$ & $\begin{array}{c}-0.221 * * \\
(0.093)\end{array}$ \\
\hline SCHOOL & $\begin{array}{c}0.167 * * * \\
(0.063)\end{array}$ & $\begin{array}{c}0.116 * * * \\
(0.018)\end{array}$ & $\begin{array}{c}0.098 * * * \\
(0.021)\end{array}$ & $\begin{array}{l}0.046^{*} \\
(0.027)\end{array}$ \\
\hline DENSITY & $\begin{array}{c}-0.114 * * * \\
(0.033)\end{array}$ & $\begin{array}{c}-0.026 * * \\
(0.010)\end{array}$ & $\begin{array}{l}-0.018 \\
(0.011)\end{array}$ & $\begin{array}{c}0.013 \\
(0.013)\end{array}$ \\
\hline DISTANCE_SP & $\begin{array}{c}0.017 \\
(0.064)\end{array}$ & $\begin{array}{l}-0.001 \\
(0.017)\end{array}$ & $\begin{array}{c}0.003 \\
(0.020)\end{array}$ & $\begin{array}{c}-0.078 * * * \\
(0.025)\end{array}$ \\
\hline TEEN & $\begin{array}{l}-2.727 \\
(2.738)\end{array}$ & $\begin{array}{l}-1.207 * \\
(0.727)\end{array}$ & $\begin{array}{l}-1.118 \\
(0.848)\end{array}$ & $\begin{array}{l}-2.519^{*} \\
(1.383)\end{array}$ \\
\hline WORK & $\begin{array}{c}3.209 * * \\
(1.470)\end{array}$ & $\begin{array}{c}0.238 \\
(0.399)\end{array}$ & $\begin{array}{c}0.012 \\
(0.481)\end{array}$ & $\begin{array}{c}0.754 \\
(0.719)\end{array}$ \\
\hline ELDER & $\begin{array}{c}-6.604 * * * \\
(1.437)\end{array}$ & $\begin{array}{c}-1.690 * * * \\
(0.429)\end{array}$ & $\begin{array}{l}-0.906^{*} \\
(0.493)\end{array}$ & $\begin{array}{c}-2.581 * * * \\
(0.751)\end{array}$ \\
\hline AGRICULTURE & $\begin{array}{c}-0.232 \\
(1.237)\end{array}$ & $\begin{array}{c}0.431 \\
(0.570)\end{array}$ & $\begin{array}{l}-0.276 \\
(0.619)\end{array}$ & $\begin{array}{c}0.486 \\
(0.603)\end{array}$ \\
\hline CONSTRUCTION & $\begin{array}{c}2.299 \\
(1.834)\end{array}$ & $\begin{array}{c}0.926 \\
(0.689)\end{array}$ & $\begin{array}{c}0.378 \\
(0.743)\end{array}$ & $\begin{array}{c}0.674 \\
(0.778)\end{array}$ \\
\hline MANUFACTURING & $\begin{array}{c}0.403 \\
(1.309)\end{array}$ & $\begin{array}{c}0.508 \\
(0.570)\end{array}$ & $\begin{array}{l}-0.162 \\
(0.619)\end{array}$ & $\begin{array}{c}0.692 \\
(0.613)\end{array}$ \\
\hline TRADE & $\begin{array}{l}-1.026 \\
(1.394)\end{array}$ & $\begin{array}{c}0.679 \\
(0.582)\end{array}$ & $\begin{array}{l}-0.205 \\
(0.643)\end{array}$ & $\begin{array}{c}0.267 \\
(0.638)\end{array}$ \\
\hline TRANSPORT & $\begin{array}{l}1.438 \\
(2.397)\end{array}$ & $\begin{array}{l}-0.099 \\
(0.796)\end{array}$ & $\begin{array}{l}-0.886 \\
(0.860)\end{array}$ & $\begin{array}{l}1.166 \\
(1.172)\end{array}$ \\
\hline SERVICES & $\begin{array}{l}1.328 \\
(1.956)\end{array}$ & $\begin{array}{c}0.332 \\
(0.675)\end{array}$ & $\begin{array}{l}-0.616 \\
(0.715)\end{array}$ & $\begin{array}{c}0.553 \\
(0.695)\end{array}$ \\
\hline PROVISION & $\begin{array}{l}-0.645 \\
(1.365)\end{array}$ & $\begin{array}{c}0.264 \\
(0.588)\end{array}$ & $\begin{array}{l}-0.782 \\
(0.651)\end{array}$ & $\begin{array}{c}0.884 \\
(0.664)\end{array}$ \\
\hline SOCIAL & $\begin{array}{l}-0.203 \\
(1.669)\end{array}$ & $\begin{array}{l}1.015 \\
(0.661)\end{array}$ & $\begin{array}{l}-0.151 \\
(0.708)\end{array}$ & $\begin{array}{l}-0.208 \\
(0.842)\end{array}$ \\
\hline GOVERNMENT & $\begin{array}{l}-0.304 \\
(1.741)\end{array}$ & $\begin{array}{c}0.490 \\
(0.607)\end{array}$ & $\begin{array}{l}-0.286 \\
(0.704)\end{array}$ & $\begin{array}{l}-0.058 \\
(0.701)\end{array}$ \\
\hline OTHER & $\begin{array}{l}-1.596 \\
(1.663) \\
\end{array}$ & $\begin{array}{c}0.240 \\
(0.649) \\
\end{array}$ & $\begin{array}{l}-0.170 \\
(0.734) \\
\end{array}$ & $\begin{array}{c}0.431 \\
(0.702) \\
\end{array}$ \\
\hline Observations & 434 & 434 & 434 & 434 \\
\hline R-squared & 0.681 & 0.855 & 0.633 & 0.802 \\
\hline
\end{tabular}




\begin{tabular}{|c|c|c|c|c|}
\hline & & & of Income in & \\
\hline & $\underset{(1)}{G D P_{-} P C_{-} 10}$ & $\begin{array}{l}\text { TOTAL } \\
\text { (2) }\end{array}$ & $\begin{array}{c}\text { FORMAL } \\
\text { (3) }\end{array}$ & $\begin{array}{c}\text { INFORMAL } \\
\text { (4) }\end{array}$ \\
\hline \multirow[t]{2}{*}{ PROB_CORRUPT } & $-0.425^{*}$ & -0.017 & $\begin{array}{l}-0.100 \\
\end{array}$ & -0.119 \\
\hline & $(0.220)$ & (0.063) & $(0.080)$ & $(0.167)$ \\
\hline \multirow{2}{*}{ MISMANAGE } & 0.052 & -0.001 & $0.014 *$ & $-0.044 * * *$ \\
\hline & $(0.035)$ & $(0.006)$ & $(0.007)$ & $(0.014)$ \\
\hline \multirow[t]{2}{*}{ SIZE_INFORMAL } & $-0.761 * * *$ & $-0.374 * * *$ & -0.094 & 0.019 \\
\hline & $(0.226)$ & $(0.072)$ & $(0.085)$ & $(0.148)$ \\
\hline \multirow[t]{2}{*}{ SYNTHESIS } & $0.193 * * *$ & 0.012 & -0.011 & 0.055 \\
\hline & $(0.061)$ & $(0.019)$ & $(0.023)$ & $(0.039)$ \\
\hline \multirow[t]{2}{*}{ POPULATION } & -0.002 & $0.048 * * *$ & $0.053 * * *$ & $0.079 * * *$ \\
\hline & $(0.037)$ & $(0.011)$ & $(0.013)$ & $(0.027)$ \\
\hline \multirow{2}{*}{$U R B A N$} & -0.108 & $-0.132 * *$ & -0.049 & $-0.414 * * *$ \\
\hline & $(0.193)$ & $(0.063)$ & $(0.077)$ & $(0.140)$ \\
\hline \multirow[t]{2}{*}{ SCHOOL } & $0.174 * * *$ & $0.135 * * *$ & $0.101 * * *$ & $0.221 * * *$ \\
\hline & $(0.052)$ & $(0.019)$ & $(0.022)$ & $(0.033)$ \\
\hline \multirow[t]{2}{*}{ DENSITY } & $-0.094 * * *$ & $-0.048 * * *$ & $-0.035^{* * *}$ & $-0.029 * *$ \\
\hline & $(0.026)$ & $(0.009)$ & $(0.010)$ & $(0.014)$ \\
\hline \multirow[t]{2}{*}{ DISTANCE_SP } & 0.008 & -0.018 & -0.013 & 0.056 \\
\hline & $(0.054)$ & $(0.015)$ & $(0.016)$ & $(0.035)$ \\
\hline \multirow[t]{2}{*}{ TEEN } & -0.738 & $-1.878^{* *}$ & -0.992 & $-7.860 * * *$ \\
\hline & (2.564) & $(0.780)$ & $(0.970)$ & (1.659) \\
\hline \multirow[t]{2}{*}{ WORK } & $4.893 * * *$ & 0.205 & 0.232 & $-3.416 * * *$ \\
\hline & $(1.333)$ & (0.409) & $(0.502)$ & $(0.930)$ \\
\hline \multirow[t]{2}{*}{ ELDER } & $-4.045^{* * *}$ & $-2.964 * * *$ & $-1.760 * * *$ & $-8.115^{* * *}$ \\
\hline & $(1.262)$ & $(0.400)$ & $(0.513)$ & (0.919) \\
\hline \multirow[t]{2}{*}{ AGRICULTURE } & -1.026 & 0.111 & -0.343 & -0.082 \\
\hline & (1.982) & $(0.828)$ & (1.013) & (1.113) \\
\hline \multirow[t]{2}{*}{ CONSTRUCTION } & 0.119 & 0.095 & -0.112 & -1.008 \\
\hline & (2.756) & (1.061) & (1.272) & (1.488) \\
\hline \multirow[t]{2}{*}{ MANUFACTURING } & -1.246 & 0.147 & -0.243 & 0.108 \\
\hline & (2.021) & $(0.816)$ & (1.008) & (1.137) \\
\hline \multirow[t]{2}{*}{ TRADE } & -2.024 & 0.502 & -0.024 & -0.155 \\
\hline & (2.037) & $(0.802)$ & $(0.981)$ & (1.180) \\
\hline \multirow{2}{*}{ TRANSPORT } & -0.988 & -0.472 & -1.264 & 1.806 \\
\hline & (2.927) & (1.118) & (1.293) & (1.939) \\
\hline \multirow[t]{2}{*}{ SERVICES } & 1.227 & -0.124 & -0.640 & 0.251 \\
\hline & (3.439) & (1.063) & (1.263) & (1.358) \\
\hline \multirow[t]{2}{*}{ PROVISION } & -1.137 & -0.130 & -0.929 & -0.157 \\
\hline & (2.073) & $(0.831)$ & (1.043) & (1.167) \\
\hline \multirow[t]{2}{*}{ SOCIAL } & -0.200 & 0.539 & -0.315 & -1.033 \\
\hline & $(2.357)$ & $(0.967)$ & (1.186) & $(1.401)$ \\
\hline \multirow{2}{*}{ GOVERNMENT } & -1.008 & 0.495 & -0.029 & 0.732 \\
\hline & $(2.171)$ & $(0.868)$ & (1.083) & $(1.256)$ \\
\hline \multirow[t]{2}{*}{ OTHER } & -1.339 & 0.077 & -0.173 & 0.820 \\
\hline & $(2.306)$ & $(0.902)$ & (1.097) & $(1.276)$ \\
\hline Observations & 331 & 331 & 331 & 331 \\
\hline R-squared & 0.668 & 0.800 & 0.512 & 0.557 \\
\hline
\end{tabular}




\begin{tabular}{|c|c|c|c|c|}
\hline & \multirow[b]{2}{*}{$\underset{(1)}{G D P_{-} P C_{-} 10}$} & \multicolumn{3}{|c|}{ Types of Income in 2010} \\
\hline & & $\begin{array}{l}\text { TOTAL } \\
\text { (2) }\end{array}$ & $\begin{array}{c}\text { FORMAL } \\
\text { (3) }\end{array}$ & $\begin{array}{c}\text { INFORMAL } \\
\text { (4) }\end{array}$ \\
\hline PROB_CORRUPT & $\begin{array}{l}-0.313 \\
(0.254)\end{array}$ & $\begin{array}{l}-0.013 \\
(0.058)\end{array}$ & $\begin{array}{c}-0.129 * \\
(0.077)\end{array}$ & $\begin{array}{c}0.228 \\
(0.142)\end{array}$ \\
\hline MISMANAGE & $\begin{array}{c}0.027 \\
(0.038)\end{array}$ & $\begin{array}{c}0.005 \\
(0.008)\end{array}$ & $\begin{array}{c}0.024 * * * \\
(0.008)\end{array}$ & $\begin{array}{l}-0.026^{*} \\
(0.014)\end{array}$ \\
\hline SIZE_INFORMAL & $\begin{array}{l}-0.380 \\
(0.274)\end{array}$ & $\begin{array}{c}-0.259 * * * \\
(0.080)\end{array}$ & $\begin{array}{c}0.084 \\
(0.091)\end{array}$ & $\begin{array}{l}-0.176 \\
(0.134)\end{array}$ \\
\hline SYNTHESIS & $\begin{array}{c}0.216 * * * \\
(0.067)\end{array}$ & $\begin{array}{c}0.022 \\
(0.020)\end{array}$ & $\begin{array}{c}0.004 \\
(0.023)\end{array}$ & $\begin{array}{c}0.049 \\
(0.031)\end{array}$ \\
\hline POPULATION & $\begin{array}{c}0.010 \\
(0.044)\end{array}$ & $\begin{array}{c}0.054 * * * \\
(0.011)\end{array}$ & $\begin{array}{c}0.054 * * * \\
(0.013)\end{array}$ & $\begin{array}{c}0.050 * * * \\
(0.019)\end{array}$ \\
\hline$U R B A N$ & $\begin{array}{l}-0.113 \\
(0.192)\end{array}$ & $\begin{array}{l}-0.099 \\
(0.070)\end{array}$ & $\begin{array}{l}-0.018 \\
(0.084)\end{array}$ & $\begin{array}{c}-0.217^{* *} \\
(0.110)\end{array}$ \\
\hline SCHOOL & $\begin{array}{c}0.187 * * * \\
(0.069)\end{array}$ & $\begin{array}{c}0.120 * * * \\
(0.023)\end{array}$ & $\begin{array}{c}0.117 * * * \\
(0.026)\end{array}$ & $\begin{array}{l}0.058^{*} \\
(0.032)\end{array}$ \\
\hline DENSITY & $\begin{array}{c}-0.107 * * * \\
(0.037)\end{array}$ & $\begin{array}{c}-0.027 * * \\
(0.012)\end{array}$ & $\begin{array}{l}-0.017 \\
(0.013)\end{array}$ & $\begin{array}{c}0.021 \\
(0.015)\end{array}$ \\
\hline DISTANCE_SP & $\begin{array}{c}0.030 \\
(0.087)\end{array}$ & $\begin{array}{c}0.014 \\
(0.023)\end{array}$ & $\begin{array}{c}0.036 \\
(0.026)\end{array}$ & $\begin{array}{l}-0.062 * \\
(0.034)\end{array}$ \\
\hline TEEN & $\begin{array}{l}-3.870 \\
(3.333)\end{array}$ & $\begin{array}{c}-2.118 * * \\
(0.875)\end{array}$ & $\begin{array}{l}-1.721^{*} \\
(1.008)\end{array}$ & $\begin{array}{l}-2.401 \\
(1.609)\end{array}$ \\
\hline WORK & $\begin{array}{l}2.927^{*} \\
(1.675)\end{array}$ & $\begin{array}{c}0.044 \\
(0.451)\end{array}$ & $\begin{array}{l}-0.039 \\
(0.528)\end{array}$ & $\begin{array}{c}0.745 \\
(0.804)\end{array}$ \\
\hline ELDER & $\begin{array}{c}-6.619 * * * \\
(1.802)\end{array}$ & $\begin{array}{c}-1.964 * * * \\
(0.526)\end{array}$ & $\begin{array}{l}-1.074 * \\
(0.588)\end{array}$ & $\begin{array}{c}-2.565 * * * \\
(0.893)\end{array}$ \\
\hline AGRICULTURE & $\begin{array}{l}-1.990 \\
(2.327)\end{array}$ & $\begin{array}{l}-0.124 \\
(0.919)\end{array}$ & $\begin{array}{l}-0.616 \\
(1.124)\end{array}$ & $\begin{array}{l}-0.058 \\
(0.855)\end{array}$ \\
\hline CONSTRUCTION & $\begin{array}{l}-1.363 \\
(3.160)\end{array}$ & $\begin{array}{l}0.355 \\
(1.137)\end{array}$ & $\begin{array}{c}0.145 \\
(1.379)\end{array}$ & $\begin{array}{c}0.518 \\
(1.160)\end{array}$ \\
\hline MANUFACTURING & $\begin{array}{l}-1.756 \\
(2.397)\end{array}$ & $\begin{array}{l}-0.071 \\
(0.916)\end{array}$ & $\begin{array}{l}-0.568 \\
(1.124)\end{array}$ & $\begin{array}{c}0.182 \\
(0.868)\end{array}$ \\
\hline TRADE & $\begin{array}{l}-2.250 \\
(2.299)\end{array}$ & $\begin{array}{c}0.121 \\
(0.886)\end{array}$ & $\begin{array}{l}-0.637 \\
(1.081)\end{array}$ & $\begin{array}{l}-0.531 \\
(0.851)\end{array}$ \\
\hline TRANSPORT & $\begin{array}{l}-2.265 \\
(3.356)\end{array}$ & $\begin{array}{l}-0.959 \\
(1.181)\end{array}$ & $\begin{array}{l}-1.682 \\
(1.394)\end{array}$ & $\begin{array}{l}1.084 \\
(1.477)\end{array}$ \\
\hline SERVICES & $\begin{array}{c}1.021 \\
(3.708)\end{array}$ & $\begin{array}{l}-0.300 \\
(1.040)\end{array}$ & $\begin{array}{c}-0.867 \\
(1.231)\end{array}$ & $\begin{array}{l}-0.174 \\
(1.003)\end{array}$ \\
\hline PROVISION & $\begin{array}{l}-2.032 \\
(2.381)\end{array}$ & $\begin{array}{l}-0.447 \\
(0.917)\end{array}$ & $\begin{array}{l}-1.326 \\
(1.131)\end{array}$ & $\begin{array}{c}0.012 \\
(0.891)\end{array}$ \\
\hline SOCIAL & $\begin{array}{l}-1.162 \\
(2.737)\end{array}$ & $\begin{array}{c}0.580 \\
(1.022)\end{array}$ & $\begin{array}{c}-0.579 \\
(1.259)\end{array}$ & $\begin{array}{c}-0.939 \\
(1.101)\end{array}$ \\
\hline GOVERNMENT & $\begin{array}{c}-1.998 \\
(2.569)\end{array}$ & $\begin{array}{l}-0.065 \\
(0.948)\end{array}$ & $\begin{array}{l}-0.802 \\
(1.187)\end{array}$ & $\begin{array}{c}-0.648 \\
(0.926)\end{array}$ \\
\hline OTHER & $\begin{array}{c}-2.078 \\
(2.639) \\
\end{array}$ & $\begin{array}{c}-0.338 \\
(0.992) \\
\end{array}$ & $\begin{array}{c}-0.749 \\
(1.193)\end{array}$ & $\begin{array}{c}0.002 \\
(0.949) \\
\end{array}$ \\
\hline Observations & 331 & 331 & 331 & 331 \\
\hline R-squared & 0.718 & 0.855 & 0.655 & 0.805 \\
\hline
\end{tabular}




\begin{tabular}{|c|c|c|c|c|}
\hline & \multirow[b]{2}{*}{$\underset{(1)}{G D P_{-} P C_{-} 10}$} & \multicolumn{3}{|c|}{ Types of Income in 2010} \\
\hline & & $\begin{array}{l}\text { TOTAL } \\
(2)\end{array}$ & $\begin{array}{c}\text { FORMAL } \\
(3) \\
\end{array}$ & $\begin{array}{c}\text { INFORMAL } \\
\text { (4) }\end{array}$ \\
\hline PROB_CORRUPT_2 & $\begin{array}{c}0.042 \\
(0.394)\end{array}$ & $\begin{array}{c}0.144 \\
(0.123)\end{array}$ & $\begin{array}{c}0.137 \\
(0.130)\end{array}$ & $\begin{array}{l}-0.138 \\
(0.270)\end{array}$ \\
\hline SIZE_INFORMAL & $\begin{array}{c}-0.769 * * * \\
(0.197)\end{array}$ & $\begin{array}{c}-0.316^{* * * *} \\
(0.060)\end{array}$ & $\begin{array}{l}-0.022 \\
(0.069)\end{array}$ & $\begin{array}{l}-0.084 \\
(0.131)\end{array}$ \\
\hline SYNTHESIS & $\begin{array}{c}0.216^{* * * *} \\
(0.056)\end{array}$ & $\begin{array}{c}0.020 \\
(0.016)\end{array}$ & $\begin{array}{l}-0.007 \\
(0.019)\end{array}$ & $\begin{array}{l}0.055^{*} \\
(0.033)\end{array}$ \\
\hline POPULATION & $\begin{array}{c}0.018 \\
(0.040)\end{array}$ & $\begin{array}{c}0.040 * * * \\
(0.009)\end{array}$ & $\begin{array}{c}0.048 * * * \\
(0.011)\end{array}$ & $\begin{array}{c}0.075 * * * \\
(0.023)\end{array}$ \\
\hline URBAN & $\begin{array}{l}-0.111 \\
(0.180)\end{array}$ & $\begin{array}{l}-0.107^{*} \\
(0.055)\end{array}$ & $\begin{array}{l}-0.066 \\
(0.065)\end{array}$ & $\begin{array}{c}-0.384 * * * \\
(0.121)\end{array}$ \\
\hline SCHOOL & $\begin{array}{c}0.160 * * * \\
(0.054)\end{array}$ & $\begin{array}{c}0.152 * * * \\
(0.017)\end{array}$ & $\begin{array}{c}0.113 * * * \\
(0.019)\end{array}$ & $\begin{array}{c}0.228 * * * \\
(0.030)\end{array}$ \\
\hline DENSITY & $\begin{array}{c}-0.095 * * * \\
(0.025)\end{array}$ & $\begin{array}{c}-0.048 * * * \\
(0.008)\end{array}$ & $\begin{array}{c}-0.034 * * * \\
(0.008)\end{array}$ & $\begin{array}{c}-0.039 * * * \\
(0.013)\end{array}$ \\
\hline DISTANCE_SP & $\begin{array}{c}0.016 \\
(0.046)\end{array}$ & $\begin{array}{l}-0.013 \\
(0.012)\end{array}$ & $\begin{array}{l}-0.018 \\
(0.014)\end{array}$ & $\begin{array}{c}0.059 * * \\
(0.029)\end{array}$ \\
\hline TEEN & $\begin{array}{l}-1.562 \\
(2.343)\end{array}$ & $\begin{array}{c}-1.529 * * \\
(0.686)\end{array}$ & $\begin{array}{l}-1.163 \\
(0.816)\end{array}$ & $\begin{array}{c}-7.982 * * * \\
(1.533)\end{array}$ \\
\hline WORK & $\begin{array}{c}4.612 * * * \\
(1.220)\end{array}$ & $\begin{array}{c}0.118 \\
(0.367)\end{array}$ & $\begin{array}{l}-0.062 \\
(0.438)\end{array}$ & $\begin{array}{c}-3.502 * * * \\
(0.830)\end{array}$ \\
\hline ELDER & $\begin{array}{c}-4.774 * * * \\
(1.189)\end{array}$ & $\begin{array}{c}-3.005 * * * \\
(0.316)\end{array}$ & $\begin{array}{c}-1.776 * * * \\
(0.384)\end{array}$ & $\begin{array}{c}-8.424 * * * \\
(0.797)\end{array}$ \\
\hline AGRICULTURE & $\begin{array}{c}0.021 \\
(1.231)\end{array}$ & $\begin{array}{c}0.758 \\
(0.516)\end{array}$ & $\begin{array}{l}-0.030 \\
(0.528)\end{array}$ & $\begin{array}{l}1.029 \\
(0.663)\end{array}$ \\
\hline CONSTRUCTION & $\begin{array}{c}2.618 \\
(1.706)\end{array}$ & $\begin{array}{l}0.915 \\
(0.620)\end{array}$ & $\begin{array}{c}0.217 \\
(0.651)\end{array}$ & $\begin{array}{c}0.925 \\
(1.019)\end{array}$ \\
\hline MANUFACTURING & $\begin{array}{c}0.103 \\
(1.276)\end{array}$ & $\begin{array}{l}0.795 \\
(0.513)\end{array}$ & $\begin{array}{l}0.078 \\
(0.528)\end{array}$ & $\begin{array}{l}1.228^{*} \\
(0.697)\end{array}$ \\
\hline TRADE & $\begin{array}{l}-1.587 \\
(1.424)\end{array}$ & $\begin{array}{l}1.096 * * \\
(0.524)\end{array}$ & $\begin{array}{c}0.283 \\
(0.559)\end{array}$ & $\begin{array}{c}0.993 \\
(0.799)\end{array}$ \\
\hline TRANSPORT & $\begin{array}{l}1.639 \\
(2.269)\end{array}$ & $\begin{array}{c}0.450 \\
(0.804)\end{array}$ & $\begin{array}{l}-0.445 \\
(0.814)\end{array}$ & $\begin{array}{c}2.255 \\
(1.465)\end{array}$ \\
\hline SERVICES & $\begin{array}{c}0.924 \\
(1.954)\end{array}$ & $\begin{array}{c}0.649 \\
(0.695)\end{array}$ & $\begin{array}{l}-0.324 \\
(0.742)\end{array}$ & $\begin{array}{c}1.294 \\
(0.843)\end{array}$ \\
\hline PROVISION & $\begin{array}{l}-0.216 \\
(1.372)\end{array}$ & $\begin{array}{c}0.559 \\
(0.537)\end{array}$ & $\begin{array}{l}-0.595 \\
(0.568)\end{array}$ & $\begin{array}{c}0.938 \\
(0.753)\end{array}$ \\
\hline SOCIAL & $\begin{array}{c}0.346 \\
(1.590)\end{array}$ & $\begin{array}{l}1.078^{*} \\
(0.636)\end{array}$ & $\begin{array}{l}0.043 \\
(0.654)\end{array}$ & $\begin{array}{c}0.411 \\
(0.975)\end{array}$ \\
\hline GOVERNMENT & $\begin{array}{c}0.409 \\
(1.564)\end{array}$ & $\begin{array}{l}1.003^{*} \\
(0.555)\end{array}$ & $\begin{array}{c}0.257 \\
(0.612)\end{array}$ & $\begin{array}{l}1.486^{*} \\
(0.809)\end{array}$ \\
\hline OTHER & $\begin{array}{l}-1.120 \\
(1.577) \\
\end{array}$ & $\begin{array}{c}0.712 \\
(0.585)\end{array}$ & $\begin{array}{c}0.310 \\
(0.649) \\
\end{array}$ & $\begin{array}{l}1.464^{*} \\
(0.852)\end{array}$ \\
\hline Observations & 434 & 434 & 434 & 434 \\
\hline R-squared & 0.624 & 0.804 & 0.522 & 0.555 \\
\hline
\end{tabular}




\begin{tabular}{|c|c|c|c|c|}
\hline & & & of Income il & \\
\hline & $\begin{array}{c}G D P_{(1)} P C_{-} 10 \\
\end{array}$ & $\begin{array}{l}\text { TOTAL } \\
\text { (2) }\end{array}$ & $\begin{array}{c}\text { FORMAL } \\
\text { (3) }\end{array}$ & $\begin{array}{c}\text { INFORMAL } \\
(4)\end{array}$ \\
\hline \multirow[t]{2}{*}{ PROB_CORRUPT_2 } & 0.263 & $0.259^{* *}$ & $0.243^{*}$ & 0.364 \\
\hline & $(0.424)$ & (0.119) & (0.144) & $(0.223)$ \\
\hline \multirow[t]{2}{*}{ SIZE_INFORMAL } & $-0.590 * *$ & $-0.253 * * *$ & 0.105 & $-0.247 * *$ \\
\hline & $(0.254)$ & $(0.064)$ & (0.074) & $(0.124)$ \\
\hline \multirow[t]{2}{*}{ SYNTHESIS } & $0.253 * * *$ & 0.023 & -0.003 & 0.040 \\
\hline & $(0.059)$ & $(0.016)$ & $(0.018)$ & $(0.026)$ \\
\hline \multirow[t]{2}{*}{ POPULATION } & -0.000 & $0.046 * * *$ & $0.051 * * *$ & $0.052 * * *$ \\
\hline & $(0.047)$ & $(0.009)$ & $(0.011)$ & $(0.016)$ \\
\hline \multirow[t]{2}{*}{$U R B A N$} & -0.097 & $-0.095^{*}$ & -0.043 & $-0.226 * *$ \\
\hline & $(0.172)$ & $(0.056)$ & $(0.068)$ & $(0.094)$ \\
\hline \multirow[t]{2}{*}{ SCHOOL } & $0.168 * * *$ & $0.119 * * *$ & $0.100 * * *$ & $0.051 *$ \\
\hline & $(0.064)$ & $(0.018)$ & $(0.022)$ & $(0.027)$ \\
\hline \multirow[t]{2}{*}{ DENSITY } & $-0.116 * * *$ & $-0.026 * *$ & $-0.019 *$ & 0.013 \\
\hline & (0.034) & $(0.010)$ & $(0.011)$ & (0.013) \\
\hline \multirow{2}{*}{ DISTANCE_SP } & 0.009 & -0.001 & 0.001 & $-0.074 * * *$ \\
\hline & (0.064) & $(0.017)$ & $(0.020)$ & $(0.025)$ \\
\hline \multirow[t]{2}{*}{ TEEN } & -2.506 & -1.112 & -0.994 & $-2.443 *$ \\
\hline & $(2.758)$ & $(0.725)$ & $(0.847)$ & $(1.381)$ \\
\hline \multirow{2}{*}{ WORK } & $3.396^{* *}$ & 0.318 & 0.117 & 0.818 \\
\hline & $(1.469)$ & $(0.397)$ & $(0.477)$ & $(0.718)$ \\
\hline \multirow[t]{2}{*}{ ELDER } & $-6.761 * * *$ & $-1.715^{* * *}$ & $-0.967 * *$ & $-2.555 * * *$ \\
\hline & $(1.446)$ & $(0.424)$ & $(0.485)$ & $(0.757)$ \\
\hline \multirow{2}{*}{ AGRICULTURE } & -0.356 & 0.400 & -0.331 & 0.486 \\
\hline & (1.214) & $(0.540)$ & $(0.591)$ & $(0.571)$ \\
\hline \multirow[t]{2}{*}{ CONSTRUCTION } & 1.927 & 0.924 & 0.273 & 0.842 \\
\hline & (1.718) & $(0.654)$ & $(0.711)$ & $(0.725)$ \\
\hline \multirow[t]{2}{*}{ MANUFACTURING } & 0.289 & 0.488 & -0.207 & 0.707 \\
\hline & (1.283) & $(0.542)$ & $(0.593)$ & $(0.583)$ \\
\hline \multirow[t]{2}{*}{ TRADE } & -1.043 & 0.652 & -0.227 & 0.223 \\
\hline & $(1.381)$ & $(0.556)$ & (0.619) & (0.613) \\
\hline \multirow[t]{2}{*}{ TRANSPORT } & 1.210 & -0.190 & -1.009 & 1.101 \\
\hline & $(2.410)$ & $(0.776)$ & $(0.841)$ & $(1.165)$ \\
\hline \multirow[t]{2}{*}{ SERVICES } & 1.266 & 0.308 & -0.649 & 0.537 \\
\hline & $(1.950)$ & $(0.640)$ & $(0.683)$ & $(0.668)$ \\
\hline \multirow[t]{2}{*}{ PROVISION } & -0.786 & 0.219 & -0.851 & 0.863 \\
\hline & (1.343) & $(0.560)$ & $(0.627)$ & (0.637) \\
\hline \multirow[t]{2}{*}{ SOCIAL } & -0.330 & 0.956 & -0.225 & -0.262 \\
\hline & (1.659) & (0.628) & (0.679) & $(0.812)$ \\
\hline \multirow[t]{2}{*}{ GOVERNMENT } & -0.334 & 0.471 & -0.307 & -0.080 \\
\hline & $(1.746)$ & $(0.581)$ & $(0.681)$ & $(0.675)$ \\
\hline \multirow[t]{2}{*}{ OTHER } & -1.729 & 0.213 & -0.225 & 0.442 \\
\hline & $(1.647)$ & $(0.622)$ & $(0.707)$ & $(0.677)$ \\
\hline Observations & 434 & 434 & 434 & 434 \\
\hline R-squared & 0.680 & 0.856 & 0.634 & 0.802 \\
\hline $\begin{array}{l}\text { Notes: ** } \\
\text { statisticall } \\
\text { included i }\end{array}$ & $\begin{array}{l}\text { y significal } \\
\text { level. Stan }\end{array}$ & $\begin{array}{l}\text { 1,* indi } \\
\text { e in pares }\end{array}$ & $\begin{array}{l}\text { lly signifi } \\
\text { ant, state }\end{array}$ & $\begin{array}{l}\text { evel, * indic } \\
\text { ixed effects }\end{array}$ \\
\hline
\end{tabular}




\begin{tabular}{|c|c|c|c|c|}
\hline & \multirow[b]{2}{*}{$\underset{(1)}{G D P_{-} P C_{-} 10}$} & \multicolumn{3}{|c|}{ Types of Income in 2010} \\
\hline & & $\begin{array}{l}\text { TOTAL } \\
\text { (2) }\end{array}$ & $\begin{array}{l}\text { FORMAL } \\
\text { (3) }\end{array}$ & $\begin{array}{c}\text { INFORMAL } \\
\text { (4) }\end{array}$ \\
\hline \multirow[t]{2}{*}{$P R O B \_C O R R U P T \_2$} & 0.047 & 0.186 & 0.125 & 0.169 \\
\hline & $(0.587)$ & $(0.184)$ & $(0.205)$ & $(0.341)$ \\
\hline \multirow{2}{*}{ MISMANAGE } & 0.048 & -0.005 & 0.010 & $-0.048 * * *$ \\
\hline & $(0.040)$ & $(0.007)$ & $(0.008)$ & $(0.015)$ \\
\hline \multirow[t]{2}{*}{ SIZE_INFORMAL } & $-0.734 * * *$ & $-0.366^{* * *}$ & -0.083 & 0.032 \\
\hline & $(0.225)$ & $(0.073)$ & $(0.086)$ & $(0.150)$ \\
\hline \multirow[t]{2}{*}{ SYNTHESIS } & $0.193 * * *$ & 0.014 & -0.010 & 0.056 \\
\hline & $(0.061)$ & $(0.020)$ & $(0.023)$ & $(0.039)$ \\
\hline \multirow[t]{2}{*}{ POPULATION } & 0.005 & $0.050 * * *$ & $0.055 * * *$ & $0.082 * * *$ \\
\hline & $(0.037)$ & $(0.011)$ & $(0.013)$ & $(0.027)$ \\
\hline \multirow{2}{*}{$U R B A N$} & -0.149 & $-0.139 * *$ & -0.062 & $-0.430 * * *$ \\
\hline & $(0.190)$ & $(0.063)$ & $(0.076)$ & $(0.138)$ \\
\hline \multirow[t]{2}{*}{ SCHOOL } & $0.182 * * *$ & $0.138 * * *$ & $0.104 * * *$ & $0.225 * * *$ \\
\hline & $(0.054)$ & $(0.020)$ & $(0.023)$ & $(0.034)$ \\
\hline \multirow[t]{2}{*}{ DENSITY } & $-0.096 * * *$ & $-0.049 * * *$ & $-0.036 * * *$ & $-0.029 * *$ \\
\hline & $(0.026)$ & $(0.009)$ & $(0.010)$ & $(0.014)$ \\
\hline \multirow[t]{2}{*}{ DISTANCE_SP } & 0.009 & -0.016 & -0.012 & 0.058 \\
\hline & $(0.054)$ & $(0.015)$ & $(0.017)$ & $(0.036)$ \\
\hline \multirow[t]{2}{*}{ TEEN } & -1.133 & $-1.984 * *$ & -1.141 & $-8.048 * * *$ \\
\hline & (2.593) & $(0.786)$ & $(0.979)$ & $(1.695)$ \\
\hline \multirow{2}{*}{ WORK } & $4.853 * * *$ & 0.202 & 0.221 & $-3.429 * * *$ \\
\hline & $(1.344)$ & $(0.408)$ & $(0.507)$ & $(0.935)$ \\
\hline \multirow[t]{2}{*}{ ELDER } & $-4.165 * * *$ & $-2.971 * * *$ & $-1.790 * * *$ & $-8.151 * * *$ \\
\hline & $(1.259)$ & $(0.402)$ & $(0.513)$ & $(0.927)$ \\
\hline \multirow[t]{2}{*}{ AGRICULTURE } & -1.143 & 0.108 & -0.370 & -0.114 \\
\hline & (1.948) & $(0.793)$ & $(0.977)$ & $(1.077)$ \\
\hline \multirow[t]{2}{*}{ CONSTRUCTION } & -0.030 & 0.118 & -0.130 & -1.026 \\
\hline & (2.735) & $(1.018)$ & $(1.230)$ & (1.454) \\
\hline \multirow[t]{2}{*}{ MANUFACTURING } & -1.364 & 0.152 & -0.264 & 0.083 \\
\hline & $(1.985)$ & $(0.782)$ & $(0.972)$ & (1.109) \\
\hline \multirow[t]{2}{*}{ TRADE } & -2.043 & 0.495 & -0.033 & -0.166 \\
\hline & $(2.016)$ & $(0.771)$ & $(0.948)$ & (1.154) \\
\hline \multirow{2}{*}{ TRANSPORT } & -1.131 & -0.498 & -1.310 & 1.749 \\
\hline & (2.928) & (1.091) & (1.263) & (1.906) \\
\hline \multirow[t]{2}{*}{ SERVICES } & 1.040 & -0.141 & -0.690 & 0.190 \\
\hline & (3.414) & (1.028) & $(1.225)$ & $(1.315)$ \\
\hline \multirow[t]{2}{*}{ PROVISION } & -1.315 & -0.144 & -0.975 & -0.213 \\
\hline & $(2.040)$ & $(0.797)$ & (1.009) & $(1.133)$ \\
\hline \multirow[t]{2}{*}{ SOCIAL } & -0.285 & 0.524 & -0.342 & -1.067 \\
\hline & (2.329) & $(0.929)$ & (1.148) & (1.367) \\
\hline \multirow{2}{*}{ GOVERNMENT } & -1.055 & 0.513 & -0.027 & 0.736 \\
\hline & (2.134) & $(0.836)$ & $(1.051)$ & (1.223) \\
\hline OTHER & -1.403 & 0.086 & -0.181 & 0.812 \\
\hline & $(2.288)$ & $(0.871)$ & (1.063) & $(1.246)$ \\
\hline Observations & 331 & 331 & 331 & 331 \\
\hline R-squared & 0.664 & 0.801 & 0.511 & 0.557 \\
\hline
\end{tabular}




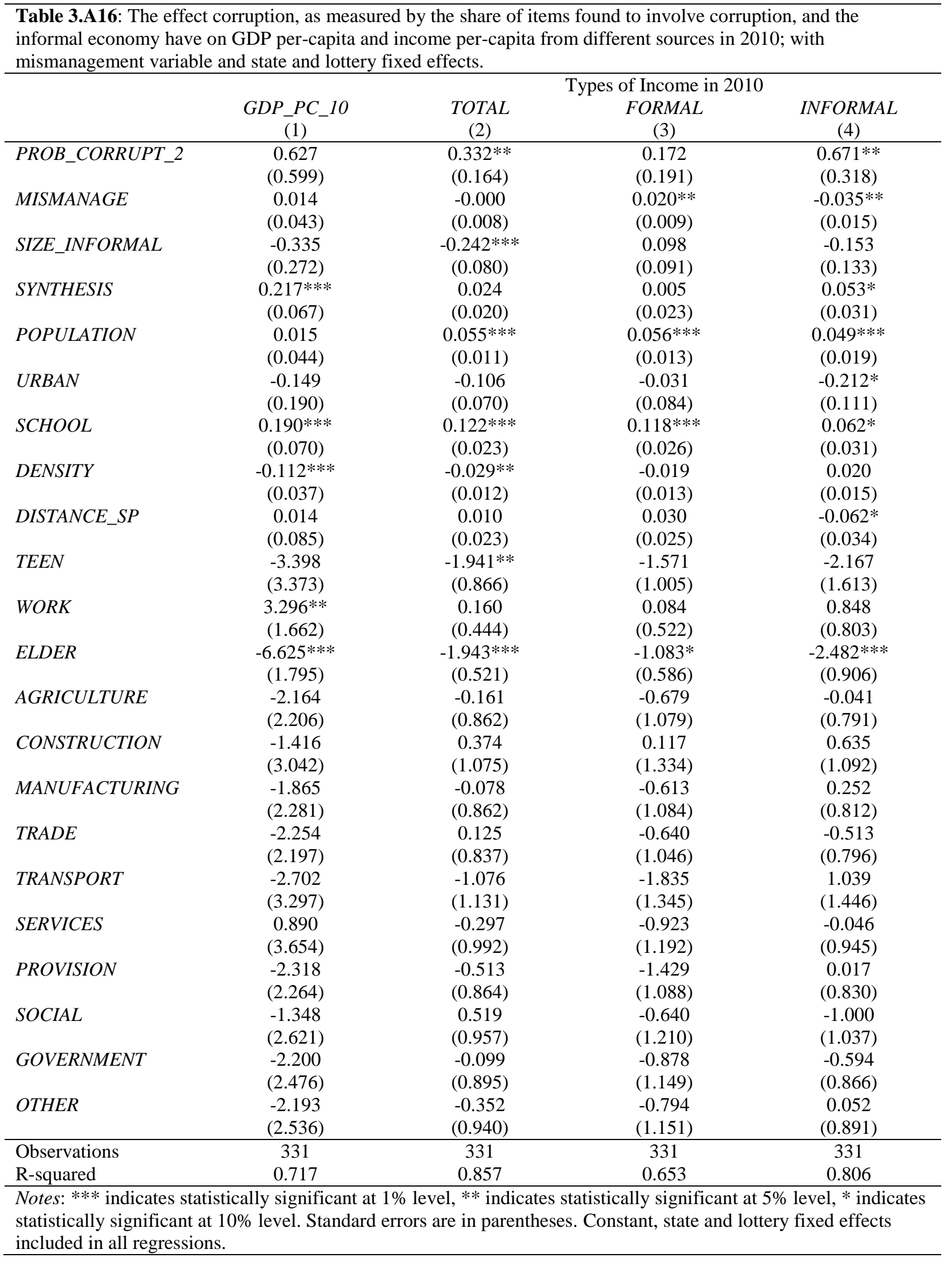




\begin{tabular}{|c|c|c|c|c|}
\hline & $\underset{(1)}{G D P_{-} P C_{-} 04}$ & $\begin{array}{c}\text { TOTAL_OO } \\
\text { (2) }\end{array}$ & GDP_PC_04 & $\begin{array}{c}\text { TOTAL_OO } \\
\text { (4) }\end{array}$ \\
\hline PROB_CORRUPT & $\begin{array}{l}-0.388^{*} \\
(0.200)\end{array}$ & $\begin{array}{c}0.042 \\
(0.092)\end{array}$ & & \\
\hline$P R O B \_C O R R U P T \_2$ & & & $\begin{array}{c}0.044 \\
(0.500)\end{array}$ & $\begin{array}{l}-0.064 \\
(0.213)\end{array}$ \\
\hline SIZE_INFORMAL & $\begin{array}{c}-1.556^{* * * *} \\
(0.550)\end{array}$ & $\begin{array}{c}0.269 \\
(0.246)\end{array}$ & $\begin{array}{c}-1.583^{* * * *} \\
(0.548)\end{array}$ & $\begin{array}{c}0.277 \\
(0.245)\end{array}$ \\
\hline SYNTHESIS & $\begin{array}{c}0.161 * * * \\
(0.062)\end{array}$ & $\begin{array}{c}0.034 \\
(0.021)\end{array}$ & $\begin{array}{c}0.166 * * * \\
(0.063)\end{array}$ & $\begin{array}{c}0.033 \\
(0.022)\end{array}$ \\
\hline POPULATION & $\begin{array}{c}0.026 \\
(0.037)\end{array}$ & $\begin{array}{c}0.064 * * * \\
(0.015)\end{array}$ & $\begin{array}{c}0.033 \\
(0.038)\end{array}$ & $\begin{array}{c}0.063 * * * \\
(0.015)\end{array}$ \\
\hline$U R B A N$ & $\begin{array}{c}0.101 \\
(0.208)\end{array}$ & $\begin{array}{c}-0.199 * * \\
(0.082)\end{array}$ & $\begin{array}{c}0.078 \\
(0.208)\end{array}$ & $\begin{array}{c}-0.196 * * \\
(0.081)\end{array}$ \\
\hline SCHOOL & $\begin{array}{c}0.126^{* *} \\
(0.058)\end{array}$ & $\begin{array}{c}0.236 * * * \\
(0.025)\end{array}$ & $\begin{array}{c}0.129 * * \\
(0.058)\end{array}$ & $\begin{array}{c}0.235 * * * \\
(0.026)\end{array}$ \\
\hline DENSITY & $\begin{array}{c}-0.122 * * * \\
(0.030)\end{array}$ & $\begin{array}{c}-0.053 * * * \\
(0.010)\end{array}$ & $\begin{array}{c}-0.125^{* * *} \\
(0.031)\end{array}$ & $\begin{array}{c}-0.053 * * * \\
(0.010)\end{array}$ \\
\hline DISTANCE_SP & $\begin{array}{c}0.049 \\
(0.052)\end{array}$ & $\begin{array}{c}-0.065^{* * *} \\
(0.017)\end{array}$ & $\begin{array}{c}0.049 \\
(0.051)\end{array}$ & $\begin{array}{c}-0.065 * * * \\
(0.017)\end{array}$ \\
\hline TEEN & $\begin{array}{l}-2.792 \\
(2.193)\end{array}$ & $\begin{array}{c}-4.263 * * * \\
(1.093)\end{array}$ & $\begin{array}{l}-2.975 \\
(2.192)\end{array}$ & $\begin{array}{c}-4.214 * * * \\
(1.099)\end{array}$ \\
\hline WORK & $\begin{array}{c}4.825 * * * \\
(1.232)\end{array}$ & $\begin{array}{c}-1.472 * * * \\
(0.555)\end{array}$ & $\begin{array}{c}4.826 * * * \\
(1.243)\end{array}$ & $\begin{array}{c}-1.471 * * * \\
(0.556)\end{array}$ \\
\hline ELDER & $\begin{array}{c}-5.445 * * * \\
(1.285)\end{array}$ & $\begin{array}{c}-4.426 * * * \\
(0.533)\end{array}$ & $\begin{array}{c}-5.540 * * * \\
(1.276)\end{array}$ & $\begin{array}{c}-4.410 * * * \\
(0.532)\end{array}$ \\
\hline AGRICULTURE & $\begin{array}{c}0.091 \\
(1.073)\end{array}$ & $\begin{array}{l}-0.218 \\
(0.643)\end{array}$ & $\begin{array}{l}0.030 \\
(1.074)\end{array}$ & $\begin{array}{l}-0.215 \\
(0.650)\end{array}$ \\
\hline CONSTRUCTION & $\begin{array}{c}1.217 \\
(1.508)\end{array}$ & $\begin{array}{c}0.122 \\
(0.803)\end{array}$ & $\begin{array}{c}0.752 \\
(1.422)\end{array}$ & $\begin{array}{c}0.170 \\
(0.793)\end{array}$ \\
\hline MANUFACTURING & $\begin{array}{l}-0.159 \\
(1.141)\end{array}$ & $\begin{array}{c}0.207 \\
(0.663)\end{array}$ & $\begin{array}{l}-0.262 \\
(1.148)\end{array}$ & $\begin{array}{c}0.218 \\
(0.671)\end{array}$ \\
\hline TRADE & $\begin{array}{l}-1.426 \\
(1.362)\end{array}$ & $\begin{array}{l}-0.103 \\
(0.660)\end{array}$ & $\begin{array}{l}-1.399 \\
(1.374)\end{array}$ & $\begin{array}{l}-0.103 \\
(0.670)\end{array}$ \\
\hline TRANSPORT & $\begin{array}{l}1.139 \\
(2.283)\end{array}$ & $\begin{array}{l}2.383^{* *} \\
(1.050)\end{array}$ & $\begin{array}{l}1.039 \\
(2.304)\end{array}$ & $\begin{array}{l}2.411^{* *} \\
(1.050)\end{array}$ \\
\hline SERVICES & $\begin{array}{c}1.082 \\
(1.987)\end{array}$ & $\begin{array}{c}0.352 \\
(0.839)\end{array}$ & $\begin{array}{l}1.060 \\
(1.986)\end{array}$ & $\begin{array}{c}0.358 \\
(0.850)\end{array}$ \\
\hline PROVISION & $\begin{array}{l}-0.450 \\
(1.237)\end{array}$ & $\begin{array}{l}-0.996 \\
(0.699)\end{array}$ & $\begin{array}{l}-0.489 \\
(1.241)\end{array}$ & $\begin{array}{l}-0.998 \\
(0.703)\end{array}$ \\
\hline SOCIAL & $\begin{array}{l}1.111 \\
(1.513)\end{array}$ & $\begin{array}{c}0.649 \\
(0.791)\end{array}$ & $\begin{array}{c}1.109 \\
(1.521)\end{array}$ & $\begin{array}{c}0.652 \\
(0.799)\end{array}$ \\
\hline GOVERNMENT & $\begin{array}{l}1.043 \\
(1.439)\end{array}$ & $\begin{array}{c}0.231 \\
(0.716)\end{array}$ & $\begin{array}{c}1.081 \\
(1.450)\end{array}$ & $\begin{array}{c}0.219 \\
(0.724)\end{array}$ \\
\hline OTHER & $\begin{array}{c}-1.794 \\
(1.358)\end{array}$ & $\begin{array}{c}0.090 \\
(0.782)\end{array}$ & $\begin{array}{l}-1.867 \\
(1.356)\end{array}$ & $\begin{array}{c}0.100 \\
(0.793)\end{array}$ \\
\hline Observations & 404 & 404 & 404 & 404 \\
\hline R-squared & 0.646 & 0.768 & 0.643 & 0.767 \\
\hline J-Statistic & 0.927 & 0.716 & 1.053 & 0.626 \\
\hline F-Statistic & $22.486 * * *$ & $22.486^{* * *}$ & $22.427 * * *$ & $22.427 * * *$ \\
\hline $\begin{array}{l}\text { Notes: } * * * \text { indicates } \\
\text { statistically significar } \\
\text { and } R A I N \text { are instrum }\end{array}$ & $\begin{array}{l}\text { lly significar } \\
\text { level. Stanc } \\
\text { SIZE_INFO }\end{array}$ & $\begin{array}{l}\text { el, } * * \text { indic } \\
\text { are in paren }\end{array}$ & $\begin{array}{l}\text { ally significa } \\
\text { tant included }\end{array}$ & $\begin{array}{l}\text { level, * indic } \\
\text { gressions. } T E\end{array}$ \\
\hline
\end{tabular}




\begin{tabular}{|c|c|c|c|c|}
\hline & $\underset{(1)}{G D P_{-} P C_{-} 10}$ & $\begin{array}{c}\text { TOTAL_10 } \\
\text { (2) }\end{array}$ & GDP_PC_10 & $\begin{array}{c}\text { TOTAL_10 } \\
\text { (4) }\end{array}$ \\
\hline PROB_CORRUPT & $\begin{array}{c}-0.426 * * \\
(0.197)\end{array}$ & $\begin{array}{c}0.058 \\
(0.063)\end{array}$ & & \\
\hline PROB_CORRUPT_2 & & & $\begin{array}{l}-0.114 \\
(0.414)\end{array}$ & $\begin{array}{c}0.183 \\
(0.137)\end{array}$ \\
\hline SIZE_INFORMAL & $\begin{array}{c}-1.163 * * \\
(0.522)\end{array}$ & $\begin{array}{l}-0.019 \\
(0.191)\end{array}$ & $\begin{array}{c}-1.176 * * \\
(0.519)\end{array}$ & $\begin{array}{l}-0.035 \\
(0.189)\end{array}$ \\
\hline SYNTHESIS & $\begin{array}{c}0.206 * * * \\
(0.057)\end{array}$ & $\begin{array}{l}0.031^{*} \\
(0.018)\end{array}$ & $\begin{array}{c}0.209 * * * \\
(0.058)\end{array}$ & $\begin{array}{l}0.033^{*} \\
(0.018)\end{array}$ \\
\hline POPULATION & $\begin{array}{c}0.027 \\
(0.037)\end{array}$ & $\begin{array}{c}0.047 * * * \\
(0.010)\end{array}$ & $\begin{array}{c}0.033 \\
(0.037)\end{array}$ & $\begin{array}{c}0.046 * * * \\
(0.010)\end{array}$ \\
\hline$U R B A N$ & $\begin{array}{c}0.016 \\
(0.184)\end{array}$ & $\begin{array}{l}-0.106^{*} \\
(0.062)\end{array}$ & $\begin{array}{l}-0.009 \\
(0.185)\end{array}$ & $\begin{array}{l}-0.104 * \\
(0.061)\end{array}$ \\
\hline SCHOOL & $\begin{array}{l}0.139 * * \\
(0.057)\end{array}$ & $\begin{array}{c}0.168^{* * * *} \\
(0.020)\end{array}$ & $\begin{array}{c}0.140 * * \\
(0.057)\end{array}$ & $\begin{array}{c}0.170 * * * \\
(0.020)\end{array}$ \\
\hline DENSITY & $\begin{array}{c}-0.097 * * * \\
(0.026)\end{array}$ & $\begin{array}{c}-0.047 * * * \\
(0.009)\end{array}$ & $\begin{array}{c}-0.099 * * * \\
(0.026)\end{array}$ & $\begin{array}{c}-0.047 * * * \\
(0.009)\end{array}$ \\
\hline DISTANCE_SP & $\begin{array}{c}0.032 \\
(0.046)\end{array}$ & $\begin{array}{l}-0.023^{*} \\
(0.013)\end{array}$ & $\begin{array}{c}0.030 \\
(0.046)\end{array}$ & $\begin{array}{l}-0.019 \\
(0.013)\end{array}$ \\
\hline TEEN & $\begin{array}{c}0.100 \\
(2.037)\end{array}$ & $\begin{array}{c}-1.646 * * \\
(0.828)\end{array}$ & $\begin{array}{l}-0.027 \\
(2.042)\end{array}$ & $\begin{array}{c}-1.705 * * \\
(0.830)\end{array}$ \\
\hline WORK & $\begin{array}{c}5.060 * * * \\
(1.142)\end{array}$ & $\begin{array}{c}0.161 \\
(0.389)\end{array}$ & $\begin{array}{c}5.064 * * * \\
(1.149)\end{array}$ & $\begin{array}{c}0.158 \\
(0.389)\end{array}$ \\
\hline ELDER & $\begin{array}{c}-4.459 * * * \\
(1.188)\end{array}$ & $\begin{array}{c}-3.313 * * * \\
(0.374)\end{array}$ & $\begin{array}{c}-4.550 * * * \\
(1.188)\end{array}$ & $\begin{array}{c}-3.313 * * * \\
(0.373)\end{array}$ \\
\hline AGRICULTURE & $\begin{array}{c}0.361 \\
(1.122)\end{array}$ & $\begin{array}{c}0.752 \\
(0.546)\end{array}$ & $\begin{array}{l}0.285 \\
(1.137)\end{array}$ & $\begin{array}{c}0.772 \\
(0.526)\end{array}$ \\
\hline CONSTRUCTION & $\begin{array}{l}2.824^{*} \\
(1.637)\end{array}$ & $\begin{array}{c}0.816 \\
(0.677)\end{array}$ & $\begin{array}{c}2.307 \\
(1.534)\end{array}$ & $\begin{array}{c}0.894 \\
(0.639)\end{array}$ \\
\hline MANUFACTURING & $\begin{array}{c}0.065 \\
(1.169)\end{array}$ & $\begin{array}{l}0.955^{*} \\
(0.552)\end{array}$ & $\begin{array}{l}-0.045 \\
(1.190)\end{array}$ & $\begin{array}{l}0.967 * \\
(0.533)\end{array}$ \\
\hline TRADE & $\begin{array}{l}-1.725 \\
(1.315)\end{array}$ & $\begin{array}{l}0.977 * \\
(0.554)\end{array}$ & $\begin{array}{l}-1.691 \\
(1.335)\end{array}$ & $\begin{array}{l}0.968^{*} \\
(0.538)\end{array}$ \\
\hline TRANSPORT & $\begin{array}{c}2.374 \\
(2.097)\end{array}$ & $\begin{array}{c}0.940 \\
(0.848)\end{array}$ & $\begin{array}{c}2.313 \\
(2.132)\end{array}$ & $\begin{array}{c}0.896 \\
(0.836)\end{array}$ \\
\hline SERVICES & $\begin{array}{c}0.930 \\
(1.768)\end{array}$ & $\begin{array}{c}0.721 \\
(0.721)\end{array}$ & $\begin{array}{c}0.916 \\
(1.786)\end{array}$ & $\begin{array}{c}0.713 \\
(0.696)\end{array}$ \\
\hline PROVISION & $\begin{array}{l}-0.149 \\
(1.300)\end{array}$ & $\begin{array}{c}0.423 \\
(0.581)\end{array}$ & $\begin{array}{l}-0.210 \\
(1.311)\end{array}$ & $\begin{array}{c}0.451 \\
(0.561)\end{array}$ \\
\hline SOCIAL & $\begin{array}{c}0.851 \\
(1.429)\end{array}$ & $\begin{array}{l}1.290^{*} \\
(0.662)\end{array}$ & $\begin{array}{c}0.854 \\
(1.452)\end{array}$ & $\begin{array}{l}1.284 * * \\
(0.644)\end{array}$ \\
\hline GOVERNMENT & $\begin{array}{c}0.788 \\
(1.432)\end{array}$ & $\begin{array}{l}1.076^{*} \\
(0.588)\end{array}$ & $\begin{array}{c}0.809 \\
(1.452)\end{array}$ & $\begin{array}{l}1.093^{*} \\
(0.569)\end{array}$ \\
\hline OTHER & $\begin{array}{c}-0.675 \\
(1.404)\end{array}$ & $\begin{array}{c}0.908 \\
(0.623)\end{array}$ & $\begin{array}{c}-0.746 \\
(1.415)\end{array}$ & $\begin{array}{c}0.909 \\
(0.605)\end{array}$ \\
\hline Observations & 404 & 404 & 404 & 404 \\
\hline R-squared & 0.641 & 0.791 & 0.638 & 0.793 \\
\hline J-Statistic & 0.849 & 1.194 & 0.933 & 1.374 \\
\hline F-Statistic & $22.486^{* * *}$ & $22.486^{* * *}$ & $22.427 * * *$ & $22.427 * * *$ \\
\hline $\begin{array}{l}\text { Notes: } * * * \text { indicates } \\
\text { statistically significant } \\
\text { and } R A I N \text { are instrum }\end{array}$ & $\begin{array}{l}\text { lly significan } \\
\text { level. Stand } \\
\text { SIZE_INFO }\end{array}$ & $\begin{array}{l}\text { el, } * * \text { indic } \\
\text { are in paren }\end{array}$ & $\begin{array}{l}\text { ally significa } \\
\text { stant included }\end{array}$ & $\begin{array}{l}\text { level, * indic } \\
\text { gressions. } T E\end{array}$ \\
\hline
\end{tabular}




\section{Chapter 3, Appendix B}

Table 3.B1: The effect of corruption and the informal economic have on GDP and income per-capita in 2000, splitting sample into two halves.

\begin{tabular}{|c|c|c|c|c|c|c|c|c|}
\hline & \multicolumn{4}{|c|}{ Corruption Above the Median } & \multicolumn{4}{|c|}{ Corruption Below or Equal to the Median } \\
\hline & \multicolumn{5}{|c|}{ Types of Income in 2000} & \multicolumn{3}{|c|}{ Types of Income in 2000} \\
\hline & $\begin{array}{c}G D P_{-} P C_{-} 04 \\
(1)\end{array}$ & $\begin{array}{c}\text { TOTAL } \\
(2) \\
\end{array}$ & $\begin{array}{c}\text { FORMAL } \\
(3)\end{array}$ & $\begin{array}{c}\text { INFORMAL } \\
(4) \\
\end{array}$ & $\begin{array}{c}G D P_{-} P C_{-} 04 \\
(1)\end{array}$ & $\begin{array}{c}\text { TOTAL } \\
(2) \\
\end{array}$ & $\begin{array}{c}\text { FORMAL } \\
\text { (3) }\end{array}$ & $\begin{array}{c}\text { INFORMAL } \\
(4) \\
\end{array}$ \\
\hline \multirow[t]{2}{*}{ PROB_CORRUPT } & $-0.546^{* *}$ & 0.002 & 0.039 & $-0.215^{*}$ & 2.082 & -2.367 & -2.291 & -0.535 \\
\hline & $(0.270)$ & $(0.092)$ & $(0.105)$ & $(0.114)$ & $(5.738)$ & $(2.002)$ & $(2.536)$ & $(2.510)$ \\
\hline \multirow[t]{2}{*}{ SIZE_INFORMAL } & $-1.194 * * *$ & $-0.348 * * *$ & $0.296 *$ & 0.105 & $-0.849 * *$ & $-0.551 * * *$ & 0.018 & -0.163 \\
\hline & $(0.243)$ & $(0.101)$ & $(0.155)$ & $(0.123)$ & $(0.337)$ & $(0.112)$ & $(0.144)$ & $(0.171)$ \\
\hline Observations & 216 & 216 & 216 & 216 & 218 & 218 & 218 & 218 \\
\hline R-squared & 0.640 & 0.799 & 0.519 & 0.614 & 0.660 & 0.815 & 0.521 & 0.646 \\
\hline $\begin{array}{l}\text { Notes: } * * * \text { indicat } \\
\text { significant at } 10 \% \\
\text { available upon req }\end{array}$ & $\begin{array}{l}\text { atistically } \\
\text { 1. Standar }\end{array}$ & ficant at & $\begin{array}{l}\text { vel, ** } \\
\text { theses. }\end{array}$ & $\begin{array}{l}\text { es statis } \\
\text { controls }\end{array}$ & $\begin{array}{l}\text { signific } \\
\text { onstant i }\end{array}$ & $\begin{array}{l}5 \% \text { leve } \\
\text { ed in all }\end{array}$ & $\begin{array}{l}\text { icates st } \\
\text { ions. Fu }\end{array}$ & $\begin{array}{l}\text { ically } \\
\text { sults }\end{array}$ \\
\hline
\end{tabular}

Table 3.B2: The effect of corruption and the informal economic have on GDP and income per-capita in 2010, splitting sample into two halves.

\begin{tabular}{|c|c|c|c|c|c|c|c|c|}
\hline & \multicolumn{4}{|c|}{ Corruption Above the Median } & \multicolumn{4}{|c|}{ Corruption Below the Median } \\
\hline & \multicolumn{5}{|c|}{ Types of Income in 2010} & \multicolumn{3}{|c|}{ Types of Income in 2010} \\
\hline & $\begin{array}{c}G D P_{-} P C_{-} 10 \\
\text { (1) }\end{array}$ & $\begin{array}{l}\text { TOTAL } \\
\text { (2) }\end{array}$ & $\begin{array}{c}\text { FORMAL } \\
\text { (3) }\end{array}$ & $\begin{array}{c}\text { INFORMAL } \\
\text { (4) }\end{array}$ & $\begin{array}{c}G D P_{-} P C_{-} 10 \\
\text { (1) }\end{array}$ & $\begin{array}{l}\text { TOTAL } \\
\text { (2) }\end{array}$ & $\begin{array}{c}\text { FORMAL } \\
\text { (3) }\end{array}$ & $\begin{array}{c}\text { INFORMAL } \\
\text { (4) }\end{array}$ \\
\hline PROB_CORRUPT & $\begin{array}{c}-0.560 * * \\
(0.266)\end{array}$ & $\begin{array}{c}0.045 \\
(0.064)\end{array}$ & $\begin{array}{l}-0.024 \\
(0.077)\end{array}$ & $\begin{array}{c}0.089 \\
(0.167)\end{array}$ & $\begin{array}{c}0.869 \\
(5.176)\end{array}$ & $\begin{array}{l}-0.525 \\
(1.895)\end{array}$ & $\begin{array}{c}0.769 \\
(2.114)\end{array}$ & $\begin{array}{c}1.716 \\
(3.841)\end{array}$ \\
\hline SIZE_INFORMAL & $\begin{array}{c}-1.033 * * * \\
(0.261)\end{array}$ & $\begin{array}{c}-0.313 * * * \\
(0.078)\end{array}$ & $\begin{array}{l}-0.014 \\
(0.088)\end{array}$ & $\begin{array}{l}-0.167 \\
(0.175)\end{array}$ & $\begin{array}{c}-0.839 * * * \\
(0.313)\end{array}$ & $\begin{array}{c}-0.399 * * * \\
(0.088)\end{array}$ & $\begin{array}{l}-0.136 \\
(0.107)\end{array}$ & $\begin{array}{l}-0.052 \\
(0.208)\end{array}$ \\
\hline Observations & 216 & 216 & 216 & 216 & 218 & 218 & 218 & 218 \\
\hline R-squared & 0.646 & 0.796 & 0.528 & 0.521 & 0.633 & 0.805 & 0.530 & 0.579 \\
\hline
\end{tabular}

Notes: *** indicates statistically significant at $1 \%$ level, ** indicates statistically significant at $5 \%$ level, * indicates statistically significant at $10 \%$ level. Standard errors are in parentheses. Basic controls and constant included in all regressions. 
Table 3.B3: The effect of corruption on GDP and income per-capita, allowing the effect to differ across lotteries.

\begin{tabular}{|c|c|c|c|c|c|c|c|c|}
\hline & \multicolumn{5}{|c|}{ Types of Income in 2000} & \multicolumn{3}{|c|}{ Types of Income in 2010} \\
\hline & $\begin{array}{c}G D P \_P C \_04 \\
(1)\end{array}$ & $\begin{array}{l}\text { TOTAL } \\
(2)\end{array}$ & $\begin{array}{c}\text { FORMAL } \\
\text { (3) }\end{array}$ & $\begin{array}{c}\text { INFORMAL } \\
\text { (4) }\end{array}$ & $\begin{array}{c}G D P \_P C_{-} 10 \\
(1)\end{array}$ & $\begin{array}{c}\text { TOTAL } \\
(2) \\
\end{array}$ & $\begin{array}{c}\text { FORMAL } \\
\text { (3) }\end{array}$ & $\begin{array}{c}\text { INFORMAL } \\
\text { (4) }\end{array}$ \\
\hline \multirow[t]{2}{*}{ Lottery 1} & $-1.054 * *$ & $-0.318 * *$ & -0.090 & $-0.548 * * *$ & -0.544 & -0.087 & $-0.242 * *$ & $0.324 * *$ \\
\hline & $(0.475)$ & $(0.141)$ & $(0.169)$ & $(0.193)$ & $(0.442)$ & $(0.098)$ & $(0.111)$ & $(0.160)$ \\
\hline \multirow[t]{2}{*}{ Lottery 2} & -1.158 & $-1.024 * *$ & $-1.356^{*}$ & $-0.903 * *$ & -1.836 & -0.225 & -0.484 & -1.015 \\
\hline & $(1.103)$ & $(0.420)$ & $(0.775)$ & $(0.391)$ & $(1.120)$ & $(0.258)$ & $(0.352)$ & $(0.624)$ \\
\hline \multirow[t]{2}{*}{ Lottery 3} & 0.249 & $0.316^{* *}$ & 0.291 & $0.413 *$ & 0.297 & 0.123 & 0.144 & $0.625^{*}$ \\
\hline & $(0.432)$ & $(0.153)$ & $(0.233)$ & $(0.219)$ & $(0.555)$ & $(0.138)$ & $(0.171)$ & $(0.367)$ \\
\hline \multirow[t]{2}{*}{ Lottery 4} & -0.608 & -0.106 & -0.107 & -0.243 & -0.580 & -0.082 & $-0.274 * * *$ & -0.025 \\
\hline & $(0.577)$ & $(0.140)$ & $(0.165)$ & $(0.364)$ & $(0.504)$ & $(0.115)$ & $(0.092)$ & $(0.186)$ \\
\hline \multirow[t]{2}{*}{ Lottery 5} & -0.037 & $-0.440 *$ & $-0.934 * * *$ & -0.198 & -0.577 & 0.016 & -0.076 & $0.697 * *$ \\
\hline & $(0.684)$ & $(0.262)$ & $(0.350)$ & $(0.368)$ & $(0.491)$ & $(0.245)$ & $(0.263)$ & $(0.330)$ \\
\hline \multirow[t]{2}{*}{ Lottery 6} & -1.700 & -0.251 & -0.424 & 0.050 & -0.671 & -0.206 & -0.021 & -0.196 \\
\hline & $(1.268)$ & $(0.397)$ & $(0.408)$ & $(0.527)$ & (1.099) & $(0.325)$ & $(0.375)$ & $(0.400)$ \\
\hline \multirow[t]{2}{*}{ Lottery 7} & -0.376 & 0.299 & 0.196 & 0.109 & -0.108 & $0.350 * *$ & 0.153 & 0.220 \\
\hline & $(0.629)$ & $(0.295)$ & (0.308) & (0357) & $(0.551)$ & $(0.161)$ & (0.199) & $(0.376)$ \\
\hline \multirow[t]{2}{*}{ Lottery 8} & -0.009 & 0.234 & 0.160 & 0.042 & 0.211 & -0.041 & -0.152 & -0.201 \\
\hline & $(0.514)$ & $(0.142)$ & $(0.197)$ & $(0.156)$ & $(0.443)$ & $(0.142)$ & $(0.163)$ & $(0.253)$ \\
\hline \multirow[t]{2}{*}{ Lottery 9} & 0.324 & 0.229 & -0.041 & 0.227 & -0.208 & 0.142 & 0.049 & $0.494 *$ \\
\hline & $(0.689)$ & $(0.180)$ & $(0.295)$ & $(0.233)$ & $(0.553)$ & $(0.161)$ & $(0.238)$ & $(0.277)$ \\
\hline \multirow[t]{2}{*}{ Lottery 10} & -0.288 & 0.095 & 0.192 & -0.307 & -0.301 & -0.063 & -0.053 & -0.097 \\
\hline & $(0.413)$ & $(0.148)$ & $(0.186)$ & $(0.245)$ & $(0.376)$ & $(0.094)$ & $(0.158)$ & $(0.137)$ \\
\hline
\end{tabular}




\section{Chapter 4, Appendix A}

\begin{tabular}{|c|c|c|c|c|}
\hline & $\begin{array}{c}\text { CONVICTIONS } \\
\text { (1) }\end{array}$ & $\begin{array}{l}\text { RATE } \\
\text { (2) }\end{array}$ & $\begin{array}{c}\text { CONVICTIONS } \\
\text { (3) }\end{array}$ & $\begin{array}{c}\text { RATE } \\
\text { (4) }\end{array}$ \\
\hline \multirow[t]{2}{*}{ IMPORTANCE } & $24.504 * * *$ & $0.095^{* *}$ & 36.711 & 0.288 \\
\hline & (2.664) & $(0.042)$ & (61.782) & $(0.492)$ \\
\hline \multirow[t]{2}{*}{ SAME_PARTY_AS_PRES } & 2.772 & 0.003 & $2.501 *$ & 0.022 \\
\hline & (1.861) & $(0.043)$ & (1.326) & $(0.044)$ \\
\hline \multirow[t]{2}{*}{ IMPORT X SAME_PARTY } & -8.000 & -0.055 & $-9.809 * * *$ & $-0.075^{*}$ \\
\hline & $(4.855)$ & $(0.047)$ & (3.405) & $(0.038)$ \\
\hline \multirow[t]{2}{*}{ COMMITTEE } & 1.089 & 0.017 & 0.152 & 0.013 \\
\hline & $(0.838)$ & $(0.012)$ & (0.905) & $(0.017)$ \\
\hline \multirow{2}{*}{$J U D_{-} W A G E$} & 2.562 & 0.069 & -0.931 & -0.040 \\
\hline & (1.959) & $(0.042)$ & (1.663) & $(0.042)$ \\
\hline \multirow[t]{2}{*}{$J U D \_A I D$} & 1.525 & 0.022 & -0.260 & 0.025 \\
\hline & $(1.719)$ & $(0.031)$ & (1.498) & $(0.037)$ \\
\hline \multirow[t]{2}{*}{ FEDERAL_AID } & $10.679 * *$ & $0.238 * * *$ & 1.017 & -0.137 \\
\hline & $(4.078)$ & $(0.082)$ & $(6.033)$ & $(0.193)$ \\
\hline \multirow[t]{2}{*}{ PRC_VOTE } & 5.054 & 0.395 & 40.034 & -0.014 \\
\hline & (30.004) & $(0.514)$ & (47.755) & $(0.985)$ \\
\hline \multirow[t]{2}{*}{ DENSITY } & -4.322 & $0.169^{* *}$ & 13.367 & -0.518 \\
\hline & (5.729) & $(0.070)$ & (115.010) & (1.349) \\
\hline \multirow[t]{2}{*}{$P O P$} & $7.782 * * *$ & $-0.067^{*}$ & -10.627 & -0.384 \\
\hline & (1.903) & $(0.035)$ & (26.775) & $(0.414)$ \\
\hline \multirow{2}{*}{ INCOME } & 12.025 & 0.095 & 16.409 & 0.163 \\
\hline & (8.908) & $(0.223)$ & $(17.049)$ & $(0.617)$ \\
\hline \multirow[t]{2}{*}{ BACHELORS } & -31.996 & -0.252 & -60.665 & -0.983 \\
\hline & (36.994) & (0.770) & (42.564) & $(0.877)$ \\
\hline \multirow[t]{2}{*}{$M E D I A N \_A G E$} & -0.460 & -0.008 & -0.845 & -0.022 \\
\hline & $(0.627)$ & $(0.011)$ & $(0.863)$ & $(0.031)$ \\
\hline \multirow[t]{2}{*}{ FIRST_TERM } & -0.945 & -0.031 & -0.582 & -0.006 \\
\hline & $(0.853)$ & $(0.019)$ & (1.018) & $(0.035)$ \\
\hline \multirow{2}{*}{ DEMOCRAT } & 0.450 & -0.002 & 0.445 & -0.035 \\
\hline & $(1.373)$ & $(0.029)$ & $(2.172)$ & $(0.042)$ \\
\hline \multirow[t]{2}{*}{$T I M E \_T R E N D$} & -1.412 & -0.025 & 0.979 & $0.074 *$ \\
\hline & (1.149) & $(0.020)$ & $(2.270)$ & $(0.044)$ \\
\hline Obs. & 250 & 250 & 250 & 250 \\
\hline $\mathrm{R}^{2}$ & 0.797 & 0.389 & 0.913 & 0.685 \\
\hline State Fixed Effects? & No & No & Yes & Yes \\
\hline \multicolumn{5}{|c|}{$\begin{array}{l}\text { Notes: *** indicates statistically significant at } 1 \% \text { level, ** indicates statistically significant at } 5 \% \text { level, * } \\
\text { indicates statistically significant at } 10 \% \text { level. Standard errors clustered by state are in parentheses. All regression } \\
\text { include constant. Column (1) and column (2) include Census region fixed effects, while column (3) and (4) } \\
\text { include state-fixed effects. }\end{array}$} \\
\hline
\end{tabular}


Table 4.A2: The effect of political importance and oversight committee membership broken down by type of committee on PIN measures of corruption.

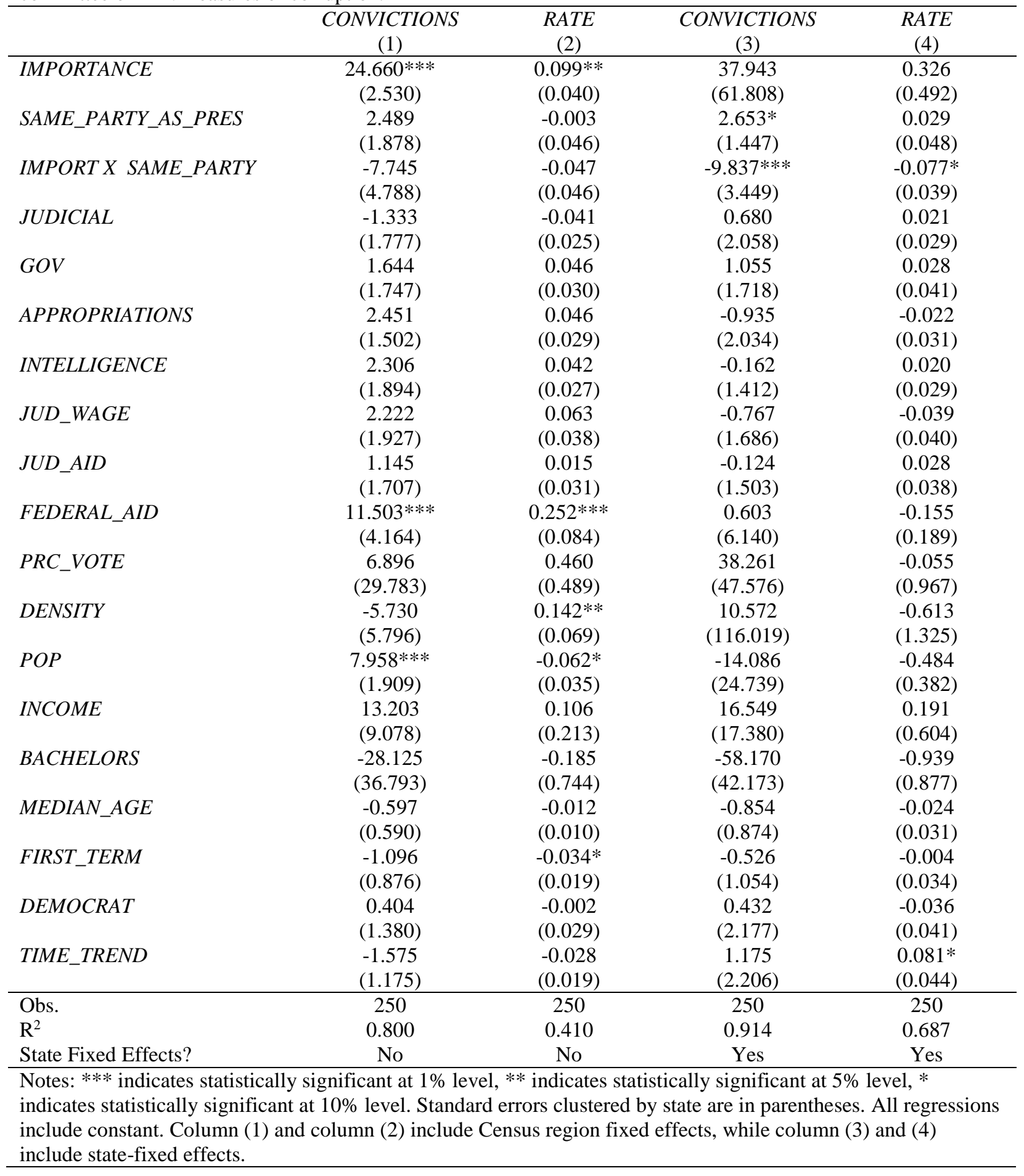


Table 4.A3: The effect of political importance and oversight committee membership on PIN measures of corruption, for democratic presidential administrations only.

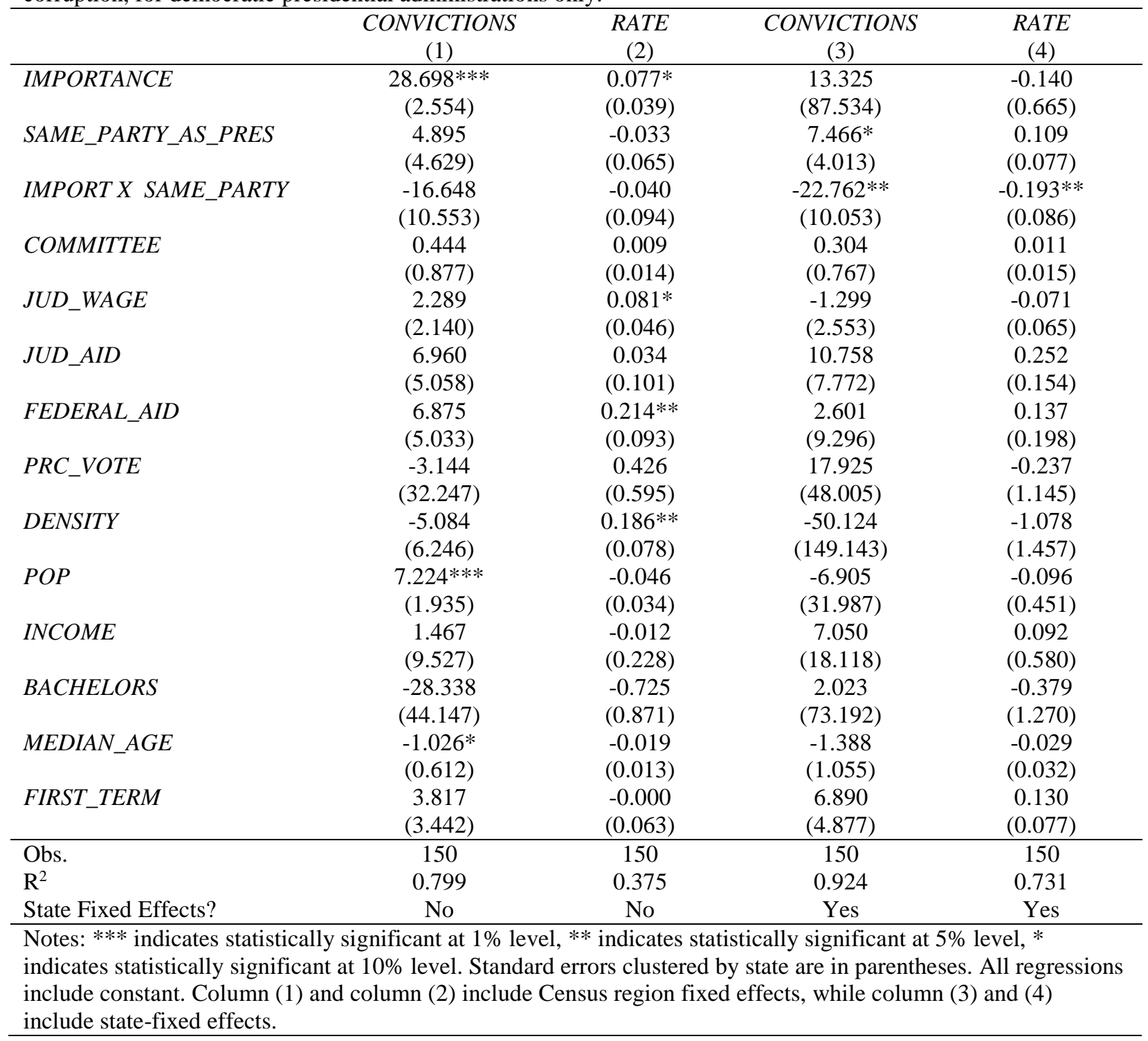


Table 4.A4: The effect of political importance and oversight committee membership on PIN measures of corruption, for republican presidential administrations only.

\begin{tabular}{|c|c|c|c|c|}
\hline & $\begin{array}{c}\text { CONVICTIONS } \\
(1)\end{array}$ & $\begin{array}{l}\text { RATE } \\
(2)\end{array}$ & $\begin{array}{c}\text { CONVICTIONS } \\
(3) \\
\end{array}$ & $\begin{array}{l}\text { RATE } \\
(4) \\
\end{array}$ \\
\hline \multirow[t]{2}{*}{ IMPORTANCE } & $14.218 * * *$ & 0.115 & 27.381 & 0.742 \\
\hline & $(2.974)$ & $(0.069)$ & $(112.371)$ & $(2.268)$ \\
\hline \multirow[t]{2}{*}{$S A M E \_P A R T Y \_A S \_P R E S$} & 5.135 & 0.115 & 0.250 & 0.056 \\
\hline & $(3.211)$ & $(0.077)$ & $(5.114)$ & $(0.160)$ \\
\hline \multirow[t]{2}{*}{ IMPORT X SAME_PARTY } & 1.434 & -0.082 & -0.632 & -0.037 \\
\hline & $(3.991)$ & $(0.063)$ & $(8.240)$ & $(0.156)$ \\
\hline \multirow[t]{2}{*}{ COMMITTEE } & $3.167 * * *$ & $0.045^{* *}$ & 2.361 & 0.036 \\
\hline & $(0.977)$ & $(0.017)$ & $(2.106)$ & $(0.069)$ \\
\hline \multirow[t]{2}{*}{$J U D \_W A G E$} & 2.441 & 0.046 & -5.389 & -0.152 \\
\hline & $(2.580)$ & $(0.045)$ & $(6.003)$ & $(0.119)$ \\
\hline \multirow[t]{2}{*}{$J U D \_A I D$} & 2.729 & 0.045 & -0.434 & 0.034 \\
\hline & $(2.137)$ & $(0.044)$ & $(2.603)$ & $(0.101)$ \\
\hline \multirow[t]{2}{*}{ FEDERAL_AID } & 6.173 & 0.167 & -15.922 & -0.822 \\
\hline & $(4.639)$ & $(0.108)$ & $(25.586)$ & $(0.889)$ \\
\hline \multirow[t]{2}{*}{$P R C_{-} V O T E$} & 29.397 & 0.634 & 35.253 & -1.074 \\
\hline & $(31.716)$ & $(0.569)$ & $(85.797)$ & $(2.168)$ \\
\hline \multirow[t]{2}{*}{ DENSITY } & -0.976 & 0.167 & 138.947 & 0.640 \\
\hline & $(4.945)$ & $(0.126)$ & $(412.006)$ & $(5.876)$ \\
\hline \multirow[t]{2}{*}{ POP } & $8.661 * * *$ & $-0.099 * *$ & -32.688 & -1.555 \\
\hline & $(2.126)$ & $(0.048)$ & $(83.138)$ & $(2.251)$ \\
\hline \multirow[t]{2}{*}{ INCOME } & 17.776 & 0.177 & 43.803 & 1.977 \\
\hline & $(11.081)$ & $(0.298)$ & $(82.361)$ & $(2.045)$ \\
\hline \multirow[t]{2}{*}{ BACHELORS } & -49.583 & -0.061 & -156.299 & -3.900 \\
\hline & $(41.387)$ & $(0.902)$ & (141.037) & $(3.220)$ \\
\hline \multirow[t]{2}{*}{$M E D I A N \_A G E$} & 0.397 & 0.008 & -3.712 & -0.052 \\
\hline & $(0.629)$ & $(0.011)$ & $(6.173)$ & $(0.133)$ \\
\hline \multirow[t]{2}{*}{ FIRST_TERM } & -1.394 & -0.039 & -4.183 & -0.086 \\
\hline & $(1.535)$ & $(0.046)$ & $(10.241)$ & $(0.164)$ \\
\hline Obs. & 150 & 150 & 150 & 150 \\
\hline $\mathrm{R}^{2}$ & 0.865 & 0.482 & 0.970 & 0.845 \\
\hline State Fixed Effects? & No & No & Yes & Yes \\
\hline \multicolumn{5}{|c|}{$\begin{array}{l}\text { Notes: } * * * \text { indicates statistically significant at } 1 \% \text { level, } * * \text { indicates statistically significant at } 5 \% \text { level, * } \\
\text { indicates statistically significant at } 10 \% \text { level. Standard errors clustered by state are in parentheses. All regressions } \\
\text { include constant. Column (1) and column (2) include Census region fixed effects, while column (3) and (4) } \\
\text { include state-fixed effects. }\end{array}$} \\
\hline
\end{tabular}


Table 4.A5: The effect of political importance and oversight committee membership on PIN measures of corruption, for when PERCENT_DEM - .50 is positive only.

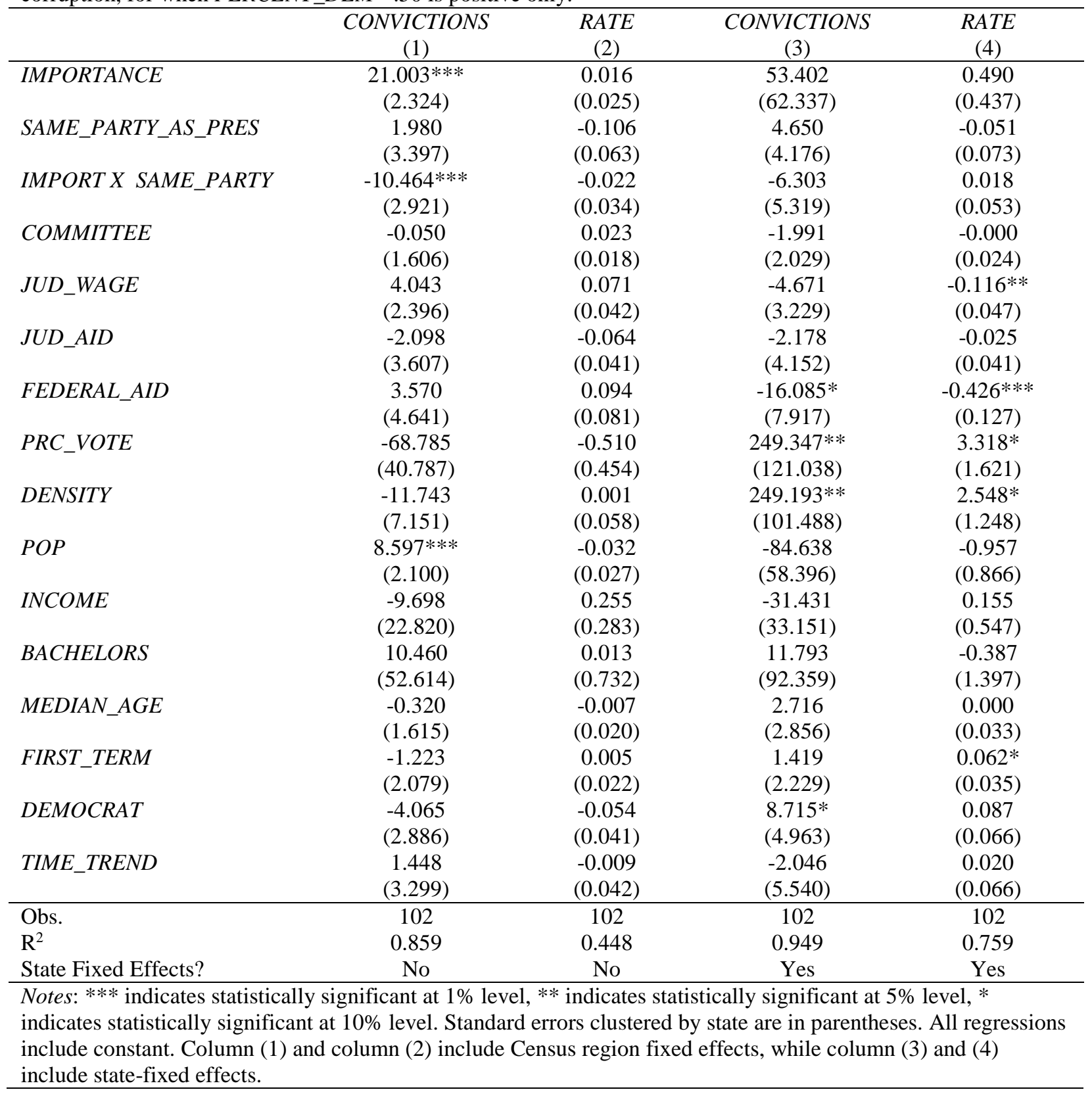


Table 4.A6: The effect of political importance and oversight committee membership on PIN measures of corruption, for when PERCENT_DEM - .50 is positive only.

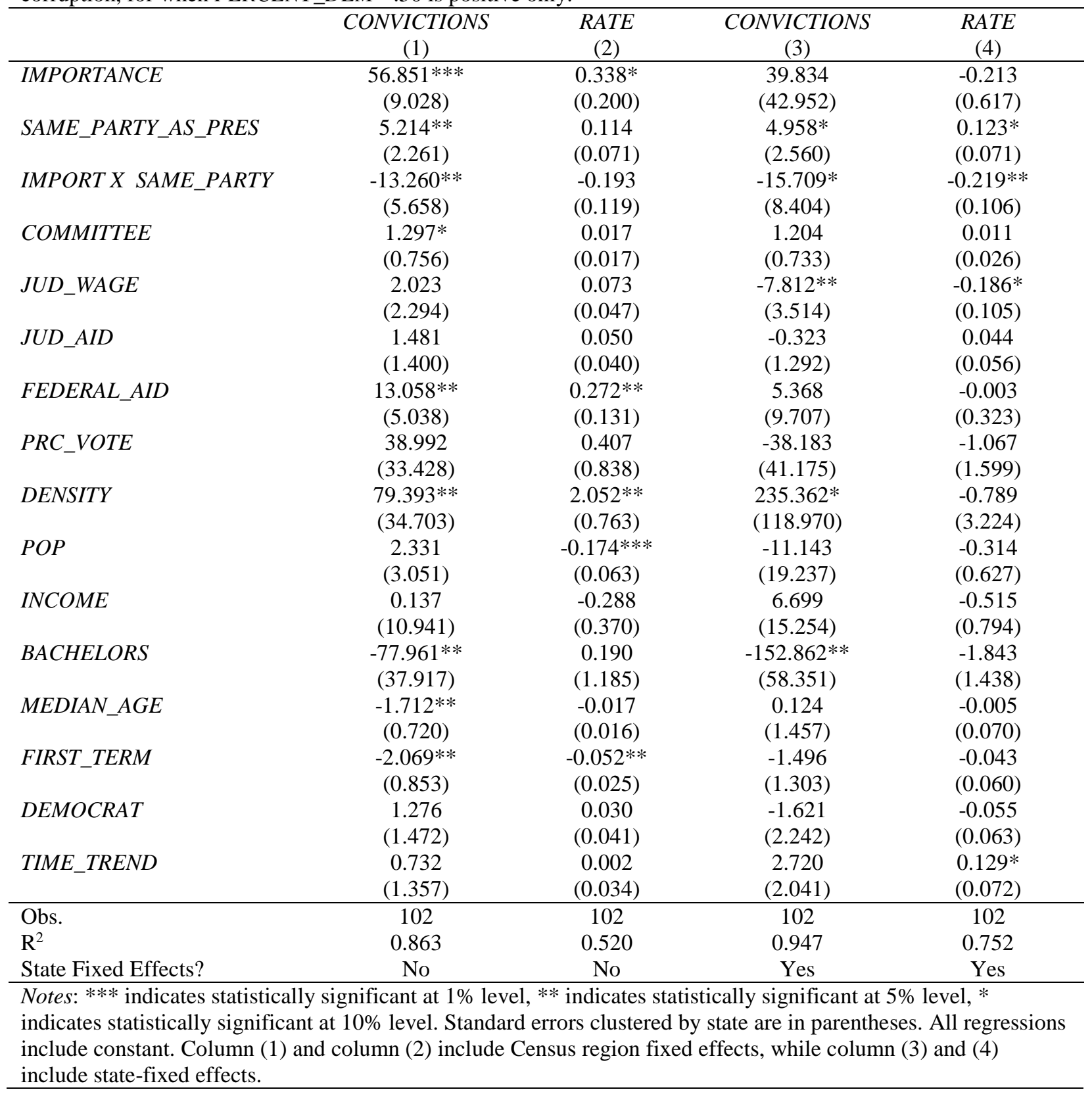


Table 4.A7: The effect political importance and oversight committee membership conditional on being the same party as the president on corruption convictions.

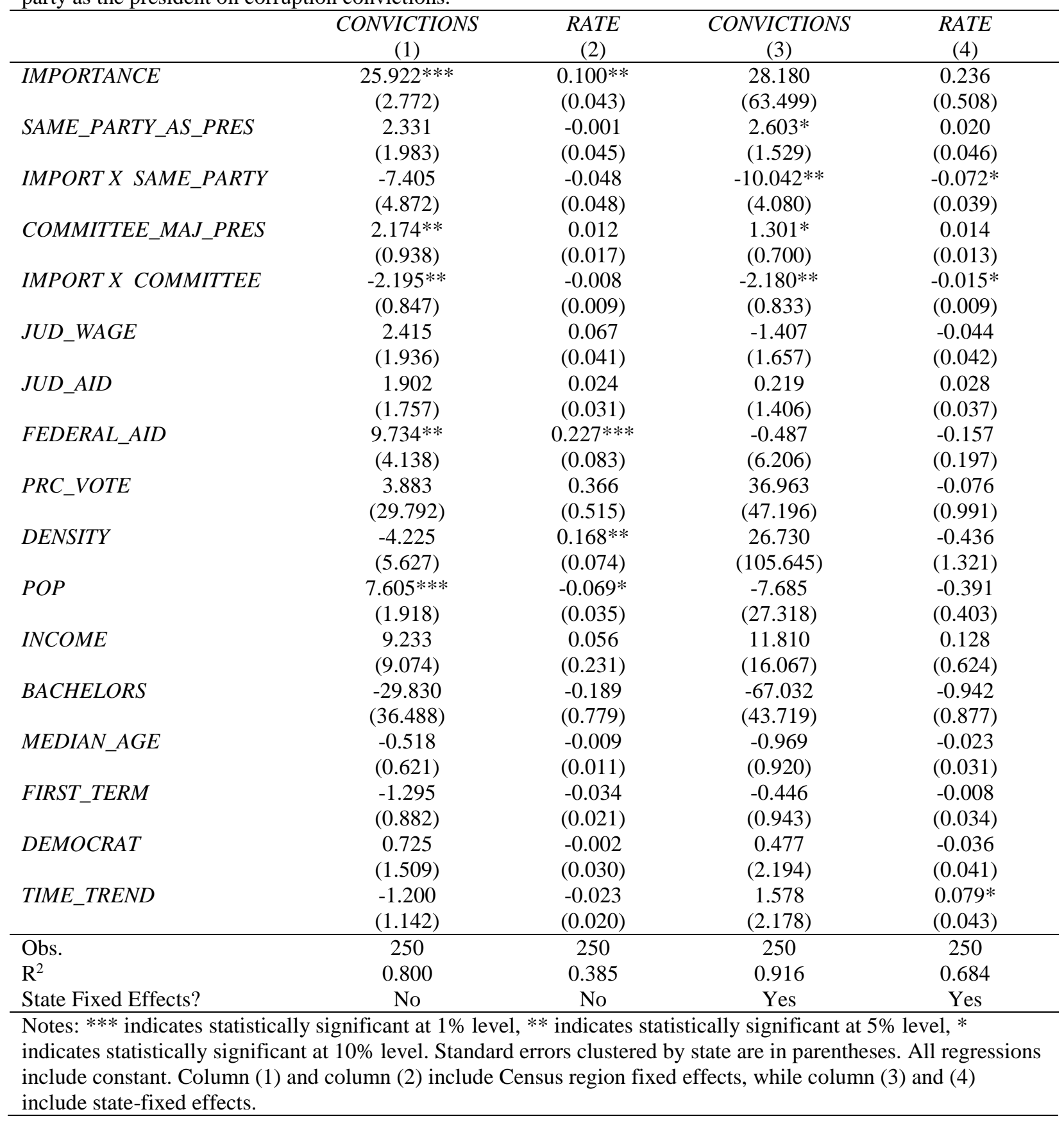




\section{Chapter, 4 Appendix B}

Table 4.B1: The effect of electoral votes and oversight committee membership in total on PIN measures of corruption.

\begin{tabular}{|c|c|c|c|c|}
\hline & $\begin{array}{c}\text { CONVICTIONS } \\
\text { (1) }\end{array}$ & $\begin{array}{l}\text { RATE } \\
(2)\end{array}$ & $\begin{array}{c}\text { CONVICTIONS } \\
\text { (3) }\end{array}$ & $\begin{array}{c}\text { RATE } \\
(4) \\
\end{array}$ \\
\hline \multirow[t]{2}{*}{ ELECTORAL } & $2.029 * * *$ & $0.007 *$ & 1.272 & 0.002 \\
\hline & $(0.179)$ & $(0.004)$ & $(2.663)$ & $(0.020)$ \\
\hline \multirow[t]{2}{*}{ SAME_PARTY_AS_PRES } & 3.108 & 0.002 & $3.580 * *$ & 0.030 \\
\hline & $(2.194)$ & $(0.049)$ & $(1.721)$ & $(0.051)$ \\
\hline \multirow[t]{2}{*}{ ELECT X SAME_PARTY } & -0.441 & -0.003 & $-0.598 * *$ & $-0.005 * *$ \\
\hline & $(0.269)$ & $(0.003)$ & $(0.236)$ & $(0.002)$ \\
\hline \multirow[t]{2}{*}{ COMMITTEE } & 0.551 & 0.015 & 0.049 & 0.013 \\
\hline & $(0.729)$ & $(0.013)$ & $(0.913)$ & $(0.017)$ \\
\hline \multirow[t]{2}{*}{$J U D \_W A G E$} & $3.301 *$ & $0.071 *$ & -0.935 & -0.043 \\
\hline & $(1.877)$ & $(0.042)$ & $(1.608)$ & $(0.043)$ \\
\hline \multirow[t]{2}{*}{$J U D \_A I D$} & 0.546 & 0.020 & -0.184 & 0.025 \\
\hline & $(1.476)$ & $(0.030)$ & $(1.506)$ & $(0.037)$ \\
\hline \multirow[t]{2}{*}{ FEDERAL_AID } & 5.764 & $0.226 * *$ & 1.105 & -0.141 \\
\hline & $(4.054)$ & $(0.086)$ & $(6.423)$ & $(0.196)$ \\
\hline \multirow[t]{2}{*}{$P R C_{-}$VOTE } & 12.774 & 0.408 & 47.762 & 0.041 \\
\hline & $(27.622)$ & $(0.502)$ & $(47.286)$ & $(0.992)$ \\
\hline \multirow[t]{2}{*}{ DENSITY } & 3.443 & $0.194 * * *$ & 2.361 & -0.547 \\
\hline & $(3.788)$ & $(0.072)$ & (102.907) & $(1.298)$ \\
\hline \multirow[t]{2}{*}{$P O P$} & 0.884 & $-0.082 *$ & -3.789 & -0.255 \\
\hline & $(1.921)$ & $(0.046)$ & $(21.734)$ & $(0.403)$ \\
\hline \multirow[t]{2}{*}{ INCOME } & 12.292 & 0.098 & 16.403 & 0.177 \\
\hline & (7.709) & $(0.228)$ & $(16.461)$ & $(0.621)$ \\
\hline \multirow[t]{2}{*}{ BACHELORS } & -24.696 & -0.245 & -71.269 & -1.099 \\
\hline & $(34.083)$ & $(0.775)$ & $(45.521)$ & $(0.890)$ \\
\hline \multirow[t]{2}{*}{$M E D I A N \_A G E$} & -0.004 & -0.007 & -0.858 & -0.021 \\
\hline & $(0.609)$ & $(0.011)$ & $(0.969)$ & $(0.031)$ \\
\hline \multirow[t]{2}{*}{ FIRST_TERM } & -0.665 & -0.030 & -0.502 & -0.004 \\
\hline & $(0.736)$ & $(0.019)$ & $(1.065)$ & $(0.036)$ \\
\hline \multirow[t]{2}{*}{ DEMOCRAT } & 0.880 & -0.001 & 0.493 & -0.034 \\
\hline & (1.403) & $(0.029)$ & $(2.285)$ & $(0.042)$ \\
\hline \multirow[t]{2}{*}{ TIME_TREND } & -1.179 & -0.025 & 0.662 & 0.068 \\
\hline & $(1.136)$ & $(0.020)$ & $(2.194)$ & $(0.045)$ \\
\hline Obs. & 250 & 250 & 250 & 250 \\
\hline $\mathrm{R}^{2}$ & 0.821 & 0.388 & 0.911 & 0.683 \\
\hline State Fixed Effects? & No & No & Yes & Yes \\
\hline \multicolumn{5}{|c|}{$\begin{array}{l}\text { Notes: } * * * \text { indicates statistically significant at } 1 \% \text { level, } * * \text { indicates statistically significant at } 5 \% \text { level, } * \\
\text { indicates statistically significant at } 10 \% \text { level. Standard errors clustered by state are in parentheses. All regressions } \\
\text { include constant. Column (1) and column (2) include Census region fixed effects, while column (3) and (4) } \\
\text { include state-fixed effects. }\end{array}$} \\
\hline
\end{tabular}




\begin{tabular}{|c|c|c|c|c|}
\hline & $\begin{array}{c}\text { CONVICTIONS } \\
\text { (1) }\end{array}$ & $\begin{array}{l}\text { RATE } \\
\text { (2) }\end{array}$ & $\begin{array}{c}\text { CONVICTIONS } \\
\text { (3) }\end{array}$ & $\begin{array}{l}\text { RATE } \\
\text { (4) }\end{array}$ \\
\hline ELECTORAL & $\begin{array}{c}2.116^{* * * *} \\
(0.180)\end{array}$ & $\begin{array}{l}0.007^{*} \\
(0.003)\end{array}$ & $\begin{array}{c}1.261 \\
(2.653)\end{array}$ & $\begin{array}{c}0.004 \\
(0.018)\end{array}$ \\
\hline SAME_PARTY_AS_PRES & $\begin{array}{l}2.661 \\
(2.339)\end{array}$ & $\begin{array}{l}-0.002 \\
(0.050)\end{array}$ & $\begin{array}{l}3.380^{*} \\
(1.958)\end{array}$ & $\begin{array}{c}0.027 \\
(0.051)\end{array}$ \\
\hline ELECT X SAME_PARTY & $\begin{array}{l}-0.405 \\
(0.283)\end{array}$ & $\begin{array}{l}-0.002 \\
(0.003)\end{array}$ & $\begin{array}{c}-0.568 * * \\
(0.270)\end{array}$ & $\begin{array}{l}-0.004 * \\
(0.002)\end{array}$ \\
\hline COMMITTEE_MAJ_PRES & $\begin{array}{c}2.032 * * \\
(0.936)\end{array}$ & $\begin{array}{c}0.010 \\
(0.018)\end{array}$ & $\begin{array}{l}1.474^{*} \\
(0.742)\end{array}$ & $\begin{array}{l}0.016 \\
(0.013)\end{array}$ \\
\hline ELECT X COMMITTEE & $\begin{array}{c}-0.122^{* *} \\
(0.059)\end{array}$ & $\begin{array}{l}-0.000 \\
(0.001)\end{array}$ & $\begin{array}{c}-0.117 * * \\
(0.045)\end{array}$ & $\begin{array}{c}-0.001^{* *} \\
(0.000)\end{array}$ \\
\hline$J U D \_W A G E$ & $\begin{array}{l}3.277^{*} \\
(1.858)\end{array}$ & $\begin{array}{l}0.069^{*} \\
(0.041)\end{array}$ & $\begin{array}{l}-1.144 \\
(1.527)\end{array}$ & $\begin{array}{l}-0.045 \\
(0.043)\end{array}$ \\
\hline$J U D \_A I D$ & $\begin{array}{c}0.813 \\
(1.482)\end{array}$ & $\begin{array}{c}0.022 \\
(0.030)\end{array}$ & $\begin{array}{c}0.261 \\
(1.425)\end{array}$ & $\begin{array}{l}0.028 \\
(0.037)\end{array}$ \\
\hline FEDERAL_AID & $\begin{array}{c}4.989 \\
(4.148)\end{array}$ & $\begin{array}{c}0.216^{* * *} \\
(0.087)\end{array}$ & $\begin{array}{c}0.075 \\
(6.574)\end{array}$ & $\begin{array}{l}-0.157 \\
(0.199)\end{array}$ \\
\hline PRC_VOTE & $\begin{array}{c}13.669 \\
(27.628)\end{array}$ & $\begin{array}{c}0.386 \\
(0.506)\end{array}$ & $\begin{array}{c}45.027 \\
(46.490)\end{array}$ & $\begin{array}{l}-0.019 \\
(0.998)\end{array}$ \\
\hline DENSITY & $\begin{array}{c}3.657 \\
(3.815)\end{array}$ & $\begin{array}{c}0.194 * * \\
(0.075)\end{array}$ & $\begin{array}{c}10.297 \\
(97.954)\end{array}$ & $\begin{array}{l}-0.506 \\
(1.278)\end{array}$ \\
\hline$P O P$ & $\begin{array}{c}0.618 \\
(1.943)\end{array}$ & $\begin{array}{l}-0.086^{*} \\
(0.045)\end{array}$ & $\begin{array}{l}-3.950 \\
(21.957)\end{array}$ & $\begin{array}{l}-0.296 \\
(0.375)\end{array}$ \\
\hline INCOME & $\begin{array}{l}10.908 \\
(8.013)\end{array}$ & $\begin{array}{c}0.065 \\
(0.237)\end{array}$ & $\begin{array}{c}11.609 \\
(16.121)\end{array}$ & $\begin{array}{c}0.136 \\
(0.629)\end{array}$ \\
\hline BACHELORS & $\begin{array}{l}-25.413 \\
(33.701)\end{array}$ & $\begin{array}{l}-0.185 \\
(0.784)\end{array}$ & $\begin{array}{l}-74.992 \\
(46.979)\end{array}$ & $\begin{array}{l}-1.034 \\
(0.894)\end{array}$ \\
\hline MEDIAN_AGE & $\begin{array}{l}-0.032 \\
(0.595)\end{array}$ & $\begin{array}{l}-0.008 \\
(0.011)\end{array}$ & $\begin{array}{l}-0.992 \\
(1.014)\end{array}$ & $\begin{array}{l}-0.023 \\
(0.031)\end{array}$ \\
\hline FIRST_TERM & $\begin{array}{l}-0.909 \\
(0.760)\end{array}$ & $\begin{array}{l}-0.033 \\
(0.021)\end{array}$ & $\begin{array}{l}-0.558 \\
(1.012)\end{array}$ & $\begin{array}{l}-0.007 \\
(0.035)\end{array}$ \\
\hline DEMOCRAT & $\begin{array}{l}1.041 \\
(1.492)\end{array}$ & $\begin{array}{l}-0.002 \\
(0.030)\end{array}$ & $\begin{array}{l}0.341 \\
(2.309)\end{array}$ & $\begin{array}{l}-0.037 \\
(0.042)\end{array}$ \\
\hline TIME_TREND & $\begin{array}{c}-1.062 \\
(1.140)\end{array}$ & $\begin{array}{l}-0.023 \\
(0.020)\end{array}$ & $\begin{array}{l}1.285 \\
(2.140)\end{array}$ & $\begin{array}{l}0.075^{*} \\
(0.044)\end{array}$ \\
\hline Obs. & 250 & 250 & 250 & 250 \\
\hline $\mathrm{R}^{2}$ & 0.823 & 0.384 & 0.913 & 0.683 \\
\hline State Fixed Effects? & No & No & Yes & Yes \\
\hline \multicolumn{5}{|c|}{$\begin{array}{l}\text { Notes: } * * * \text { indicates statistically significant at } 1 \% \text { level, } * * \text { indicates statistically significant at } 5 \% \text { level, * } \\
\text { indicates statistically significant at } 10 \% \text { level. Standard errors clustered by state are in parentheses. All regression } \\
\text { include constant. Column (1) and column (2) include Census region fixed effects, while column (3) and (4) } \\
\text { include state-fixed effects. }\end{array}$} \\
\hline
\end{tabular}




\begin{tabular}{|c|c|c|c|c|}
\hline & $\begin{array}{c}\text { CONVICTIONS } \\
\text { (1) }\end{array}$ & $\begin{array}{l}\text { RATE } \\
\text { (2) }\end{array}$ & $\begin{array}{c}\text { CONVICTIONS } \\
\text { (3) }\end{array}$ & $\begin{array}{l}\text { RATE } \\
\text { (4) }\end{array}$ \\
\hline VOTE_CLOSENESS & $\begin{array}{l}280.206^{*} \\
(141.205)\end{array}$ & $\begin{array}{c}2.202 \\
(1.633)\end{array}$ & $\begin{array}{c}265.342 \\
(223.711)\end{array}$ & $\begin{array}{c}6.602 \\
(10.602)\end{array}$ \\
\hline$S A M E \_P A R T Y \_A S \_P R E S$ & $\begin{array}{l}-1.047 \\
(3.879)\end{array}$ & $\begin{array}{c}0.104 \\
(0.091)\end{array}$ & $\begin{array}{c}0.670 \\
(3.706)\end{array}$ & $\begin{array}{c}0.105 \\
(0.084)\end{array}$ \\
\hline VOTE X SAME_PARTY & $\begin{array}{l}-17.726 \\
(95.141)\end{array}$ & $\begin{array}{l}-2.638 \\
(1.781)\end{array}$ & $\begin{array}{l}-69.902 \\
(85.095)\end{array}$ & $\begin{array}{l}-2.539 \\
(1.639)\end{array}$ \\
\hline COMMITTEE & $\begin{array}{c}1.205 \\
(0.883)\end{array}$ & $\begin{array}{c}0.018 \\
(0.012)\end{array}$ & $\begin{array}{l}-0.176 \\
(1.137)\end{array}$ & $\begin{array}{c}0.011 \\
(0.017)\end{array}$ \\
\hline$J U D \_W A G E$ & $\begin{array}{l}1.986 \\
(2.395)\end{array}$ & $\begin{array}{c}0.066 \\
(0.040)\end{array}$ & $\begin{array}{l}-1.374 \\
(2.158)\end{array}$ & $\begin{array}{l}-0.048 \\
(0.044)\end{array}$ \\
\hline$J U D \_A I D$ & $\begin{array}{l}3.931^{*} \\
(2.168)\end{array}$ & $\begin{array}{c}0.031 \\
(0.033)\end{array}$ & $\begin{array}{l}-0.326 \\
(1.468)\end{array}$ & $\begin{array}{c}0.024 \\
(0.040)\end{array}$ \\
\hline FEDERAL_AID & $\begin{array}{c}23.136 * * * \\
(6.053)\end{array}$ & $\begin{array}{c}0.274 * * * \\
(0.086)\end{array}$ & $\begin{array}{c}2.763 \\
(6.879)\end{array}$ & $\begin{array}{l}-0.111 \\
(0.189)\end{array}$ \\
\hline PRC_VOTE & $\begin{array}{l}-10.012 \\
(34.284)\end{array}$ & $\begin{array}{c}0.245 \\
(0.565)\end{array}$ & $\begin{array}{c}47.070 \\
(48.966)\end{array}$ & $\begin{array}{l}-0.051 \\
(0.992)\end{array}$ \\
\hline DENSITY & $\begin{array}{l}-3.555 \\
(6.980)\end{array}$ & $\begin{array}{c}0.154 * * \\
(0.073)\end{array}$ & $\begin{array}{c}17.916 \\
(104.891)\end{array}$ & $\begin{array}{l}-0.315 \\
(1.248)\end{array}$ \\
\hline$P O P$ & $\begin{array}{c}20.222 * * * \\
(3.269)\end{array}$ & $\begin{array}{l}-0.031 \\
(0.028)\end{array}$ & $\begin{array}{c}9.419 \\
(19.564)\end{array}$ & $\begin{array}{l}-0.256 \\
(0.337)\end{array}$ \\
\hline INCOME & $\begin{array}{c}12.371 \\
(14.063)\end{array}$ & $\begin{array}{c}0.101 \\
(0.229)\end{array}$ & $\begin{array}{c}20.181 \\
(16.954)\end{array}$ & $\begin{array}{c}0.200 \\
(0.628)\end{array}$ \\
\hline BACHELORS & $\begin{array}{l}-50.482 \\
(49.366)\end{array}$ & $\begin{array}{l}-0.189 \\
(0.808)\end{array}$ & $\begin{array}{l}-70.787 \\
(55.710)\end{array}$ & $\begin{array}{l}-0.965 \\
(0.898)\end{array}$ \\
\hline$M E D I A N \_A G E$ & $\begin{array}{l}-0.848 \\
(0.761)\end{array}$ & $\begin{array}{l}-0.008 \\
(0.012)\end{array}$ & $\begin{array}{l}-0.255 \\
(1.002)\end{array}$ & $\begin{array}{l}-0.015 \\
(0.033)\end{array}$ \\
\hline FIRST_TERM & $\begin{array}{l}-1.395 \\
(1.037)\end{array}$ & $\begin{array}{l}-0.030 \\
(0.020)\end{array}$ & $\begin{array}{l}-0.393 \\
(0.991)\end{array}$ & $\begin{array}{l}-0.005 \\
(0.034)\end{array}$ \\
\hline DEMOCRAT & $\begin{array}{c}0.208 \\
(1.660)\end{array}$ & $\begin{array}{c}0.002 \\
(0.028)\end{array}$ & $\begin{array}{l}1.563 \\
(2.295)\end{array}$ & $\begin{array}{l}-0.023 \\
(0.042)\end{array}$ \\
\hline TIME_TREND & $\begin{array}{c}-3.186 * * \\
(1.487) \\
\end{array}$ & $\begin{array}{r}-0.032^{*} \\
(0.018) \\
\end{array}$ & $\begin{array}{l}-0.920 \\
(2.102) \\
\end{array}$ & $\begin{array}{c}0.057 \\
(0.046) \\
\end{array}$ \\
\hline Obs. & 250 & 250 & 250 & 250 \\
\hline $\mathrm{R}^{2}$ & 0.712 & 0.384 & 0.901 & 0.683 \\
\hline State Fixed Effects? & No & No & Yes & Yes \\
\hline $\begin{array}{l}\text { Notes: *** indicates statist } \\
\text { indicates statistically signi } \\
\text { include constant. Column } \\
\text { include state-fixed effects. }\end{array}$ & $\begin{array}{l}\text { nnificant at } 1 \% \text { le } \\
10 \% \text { level. Stand } \\
\text { olumn (2) include }\end{array}$ & $\begin{array}{l}\text { indicates } \\
\text { ors cluster } \\
\text { us region } \mathrm{f}\end{array}$ & $\begin{array}{l}\text { cally significant a } \\
\text { tate are in parentl } \\
\text { fects, while colur }\end{array}$ & $\begin{array}{l}\text { vel, * } \\
\text { ll regressior } \\
\text { and (4) }\end{array}$ \\
\hline
\end{tabular}




\begin{tabular}{|c|c|c|c|c|}
\hline & $\begin{array}{c}\text { CONVICTIONS } \\
\text { (1) }\end{array}$ & $\begin{array}{l}\text { RATE } \\
\text { (2) }\end{array}$ & $\begin{array}{c}\text { CONVICTIONS } \\
\text { (3) }\end{array}$ & $\begin{array}{l}\text { RATE } \\
\text { (4) }\end{array}$ \\
\hline VOTING_CLOSENESS & $\begin{array}{l}287.419^{*} \\
(145.981)\end{array}$ & $\begin{array}{c}2.351 \\
(1.742)\end{array}$ & $\begin{array}{c}241.254 \\
(215.886)\end{array}$ & $\begin{array}{c}6.448 \\
(11.034)\end{array}$ \\
\hline SAME_PARTY_AS_PRES & $\begin{array}{l}-2.036 \\
(4.247)\end{array}$ & $\begin{array}{c}0.094 \\
(0.097)\end{array}$ & $\begin{array}{c}0.455 \\
(3.778)\end{array}$ & $\begin{array}{c}0.102 \\
(0.087)\end{array}$ \\
\hline VOTE X SAME_PARTY & $\begin{array}{c}-3.348 \\
(99.417)\end{array}$ & $\begin{array}{l}-2.476 \\
(1.871)\end{array}$ & $\begin{array}{l}-68.513 \\
(86.327)\end{array}$ & $\begin{array}{l}-2.499 \\
(1.684)\end{array}$ \\
\hline COMMITTEE_MAJ_PRES & $\begin{array}{l}2.653 \\
(2.462)\end{array}$ & $\begin{array}{c}0.028 \\
(0.038)\end{array}$ & $\begin{array}{l}3.857 * \\
(1.968)\end{array}$ & $\begin{array}{l}0.026 \\
(0.039)\end{array}$ \\
\hline VOTE X COMMITTEE & $\begin{array}{l}-26.499 \\
(41.108)\end{array}$ & $\begin{array}{l}-0.403 \\
(0.675)\end{array}$ & $\begin{array}{c}-77.300 * * \\
(37.902)\end{array}$ & $\begin{array}{l}-0.457 \\
(0.703)\end{array}$ \\
\hline$J U D \_W A G E$ & $\begin{array}{l}1.749 \\
(2.364)\end{array}$ & $\begin{array}{c}0.062 \\
(0.039)\end{array}$ & $\begin{array}{l}-1.858 \\
(2.207)\end{array}$ & $\begin{array}{l}-0.053 \\
(0.045)\end{array}$ \\
\hline$J U D \_A I D$ & $\begin{array}{l}4.153^{*} \\
(2.253)\end{array}$ & $\begin{array}{c}0.033 \\
(0.033)\end{array}$ & $\begin{array}{l}-0.273 \\
(1.420)\end{array}$ & $\begin{array}{c}0.024 \\
(0.040)\end{array}$ \\
\hline FEDERAL_AID & $\begin{array}{c}22.690 * * * \\
(6.154)\end{array}$ & $\begin{array}{c}0.268 * * * \\
(0.088)\end{array}$ & $\begin{array}{c}2.254 \\
(6.880)\end{array}$ & $\begin{array}{l}-0.122 \\
(0.192)\end{array}$ \\
\hline PRC_VOTE & $\begin{array}{l}-13.721 \\
(34.413)\end{array}$ & $\begin{array}{c}0.190 \\
(0.562)\end{array}$ & $\begin{array}{c}43.642 \\
(48.251)\end{array}$ & $\begin{array}{l}-0.105 \\
(1.007)\end{array}$ \\
\hline DENSITY & $\begin{array}{l}-3.830 \\
(6.835)\end{array}$ & $\begin{array}{c}0.152 * * \\
(0.075)\end{array}$ & $\begin{array}{c}33.494 \\
(102.608)\end{array}$ & $\begin{array}{l}-0.226 \\
(1.284)\end{array}$ \\
\hline$P O P$ & $\begin{array}{c}20.173 * * * \\
(3.279)\end{array}$ & $\begin{array}{l}-0.033 \\
(0.028)\end{array}$ & $\begin{array}{c}8.704 \\
(20.236)\end{array}$ & $\begin{array}{l}-0.293 \\
(0.336)\end{array}$ \\
\hline INCOME & $\begin{array}{c}10.157 \\
(14.155)\end{array}$ & $\begin{array}{c}0.061 \\
(0.238)\end{array}$ & $\begin{array}{c}20.237 \\
(16.970)\end{array}$ & $\begin{array}{c}0.197 \\
(0.636)\end{array}$ \\
\hline BACHELORS & $\begin{array}{l}-45.465 \\
(49.450)\end{array}$ & $\begin{array}{l}-0.091 \\
(0.815)\end{array}$ & $\begin{array}{l}-71.904 \\
(54.645)\end{array}$ & $\begin{array}{l}-0.885 \\
(0.909)\end{array}$ \\
\hline MEDIAN_AGE & $\begin{array}{l}-0.861 \\
(0.770)\end{array}$ & $\begin{array}{l}-0.008 \\
(0.013)\end{array}$ & $\begin{array}{l}-0.037 \\
(1.108)\end{array}$ & $\begin{array}{l}-0.015 \\
(0.033)\end{array}$ \\
\hline FIRST_TERM & $\begin{array}{l}-2.010^{*} \\
(1.110)\end{array}$ & $\begin{array}{l}-0.034 \\
(0.022)\end{array}$ & $\begin{array}{l}-0.108 \\
(0.935)\end{array}$ & $\begin{array}{l}-0.005 \\
(0.033)\end{array}$ \\
\hline DEMOCRAT & $\begin{array}{c}0.258 \\
(1.772)\end{array}$ & $\begin{array}{c}0.003 \\
(0.029)\end{array}$ & $\begin{array}{c}2.294 \\
(2.373)\end{array}$ & $\begin{array}{l}-0.020 \\
(0.042)\end{array}$ \\
\hline TIME_TREND & $\begin{array}{c}-3.231 * * \\
(1.517)\end{array}$ & $\begin{array}{l}-0.030 \\
(0.019)\end{array}$ & $\begin{array}{l}-0.935 \\
(2.207)\end{array}$ & $\begin{array}{c}0.059 \\
(0.047)\end{array}$ \\
\hline Obs. & 250 & 250 & 250 & 250 \\
\hline $\mathrm{R}^{2}$ & 0.711 & 0.379 & 0.902 & 0.682 \\
\hline State Fixed Effects? & No & No & Yes & Yes \\
\hline \multicolumn{5}{|c|}{$\begin{array}{l}\text { Notes: } * * * \text { indicates statistically significant at } 1 \% \text { level, } * * \text { indicates statistically significant at } 5 \% \text { level, * } \\
\text { indicates statistically significant at } 10 \% \text { level. Standard errors clustered by state are in parentheses. All regressior } \\
\text { include constant. Column (1) and column (2) include Census region fixed effects, while column (3) and (4) } \\
\text { include state-fixed effects. }\end{array}$} \\
\hline
\end{tabular}


Jamie Bologna

Department of Economics

Email: jbologna@mix.wvu.edu

West Virginia University

Phone: 1-724-882-0074

1601 University Avenue

Website: www.jamielbologna.com

P.O. Box 6025

Morgantown, WV 26506-6025

Updated: February 2016

Education:

Ph.D., Economics, West Virginia University, expected May 2016

Dissertation Defended: November 2015

Dissertation: Three Essays on the Economics of Corruption

Dissertation Chair: Andrew T. Young

B.S., Business Economics, (summa cum laude), Penn State Behrend, 2011

Research Interests:

Primary: Growth and Development Economics, Economics of Corruption

Secondary: New Institutional Economics, Urban and Regional Economics, Spatial Econometric

Analysis

Papers Published/Forthcoming:

"The Effect of Informal Employment and Corruption on Income Levels in Brazil" Journal of Comparative Economics (forthcoming). http://papers.ssrn.com/sol3/papers.cfm?abstract id=2489057

"Crises and Government: Some Empirical Evidence," (with Andrew T. Young) Contemporary Economic Policy (forthcoming). http://papers.ssrn.com/sol3/papers.cfm?abstract id=2313846

"A Spatial Analysis of Incomes and Institutional Quality: Evidence from US Metropolitan Areas," (with Donald J. Lacombe and Andrew T. Young) Journal of Institutional Economics (forthcoming). http://dx.doi.org/10.1017/S1744137415000156

"Entrepreneurship and Corruption: Evidence from Brazilian Municipalities," (with Amanda Ross) (2015) Public Choice 165(1), 59-77. http://link.springer.com/article/10.1007\%2Fs11127-015-0292-5

"A Spatial Analysis of Entrepreneurship and Institutional Quality: Evidence from U.S. Metropolitan Areas," (2015) Journal of Regional Analysis and Policy 44(2), 109-131. http://www.jrap-journal.org/pastvolumes/2010/v44/jrap_v44_n2_a2_bologna.pdf

"Is the Internet an Effective Mechanism for Reducing Corruption Experience? Evidence from a Cross-Section of Countries," (2014) Applied Economics Letters 21(10), 687-691. http://www.tandfonline.com/doi/abs/10.1080/13504851.2014.884692? journalCode=rael20

\section{Papers with Revisions Requested:}

"Contagious Corruption, Informal Employment, and Income: Evidence from Brazilian Municipalities" at The Annals of Regional Science http://papers.ssrn.com/sol3/papers.cfm?abstract_id=2557648 
"Corruption, Product Market Competition, and Institutional Quality: Empirical Evidence from the US States" at Economic Inquiry http://papers.ssrn.com/sol3/papers.cfm?abstract_id $=2662203$

\section{Papers Under Review:}

"Corruption: The Good, the Bad, and the Uncertain" http://papers.ssrn.com/sol3/papers.cfm?abstract_id $=2379061$

"Executive Influence over Reported Corruption Convictions: Are Conviction Rates a Biased Measure of US State-Level Corruption?" http://papers.ssrn.com/sol3/papers.cfm?abstract_id $=2662208$

"Political Influence over the Number of Corruption Convictions: Evidence from Detailed Individual Case Files" http://papers.ssrn.com/sol3/papers.cfm?abstract id $=2731250$

\section{Working Papers:}

"Does the Effect Corruption has on Income Inequality Depend on the Informal Sector?" (with Sean E. Mulholland) (September 2015)

"Does Corruption Impact the Informal-Formal Sector Wage Gap? Evidence from Brazil" (with Amir B. Ferreira Neto) (April 2015)

\section{Book Chapters:}

"Economic Freedom Research: Some Comments and Suggestions," (with Joshua C. Hall) in Joshua C. Hall (eds.) Economic Freedom and Economic Education, Ideas and Influence of James Gwartney. Volume VI in The Annual Proceedings of the Wealth and Well-Being of Nations. (2014): Beloit, Beloit College Press.

"Sub-national Indices of Economic Freedom," (with Dean Stansel) in Richard J. Cebula, Joshua C. Hall, Franklin G. Mixon, and James E. Payne (eds.) Economic Behavior, Economic

Freedom, and Entrepreneurship. (forthcoming): Edward Elgar.

\section{Teaching Experience:}

West Virginia University

Principles of Microeconomics, Spring 2013, Fall 2015

Principles of Microeconomics (online), Summer 2015

Survey of Economics (130 students), Fall 2014

Intermediate Macroeconomic Theory, Summer 2014

Principles of Macroeconomics (online), Summer 2013

\section{Conference and Seminar Presentations:}

2016: Penn State Behrend Black School of Business Economics and Liberty Lecture Series (scheduled), The Association of Private Enterprise Education Conference (scheduled), George Mason University Mercatus Center (scheduled), University of Puget Sound Department of Economics, Rochester Institute of Technology Department of Economics, University of Louisville Department of Economics, University of Evansville Schroeder School of Business, Texas Tech University Free Market Institute and Department of Agricultural and Applied Economics, Berry College Department of Economics 
2015: West Virginia University Department of Economics, Southern Economic Association Conference, Saint Vincent College Alex G. McKenna School of Business, Economics, and Government, Western Economic Association International, Southern Regional Science Association Conference, Public Choice Society Conference

2014: Southern Economic Association Conference, The Association of Private Enterprise Education Conference, Public Choice Society Conference

2013: Southern Economic Association Conference, Ohio State University Omicron Delta Epsilon and the Free Enterprise Society Lecture Series

2012: The Association of Private Enterprise Education

\section{Fellowships, Awards, and Grants:}

Best Doctoral Student Award, West Virginia University, 2016

Jon Vilasuso Advanced Doctoral Student Award, West Virginia University, 2015

Jon Vilasuso Doctoral Student Publication Award, West Virginia University, 2014

Humane Studies Fellowship, Institute for Humane Studies, 2013 - Present

Tom and Sharon DeWitt Fellowship, West Virginia University, 2013 - 2015

Kendrick Summer Research Grant, West Virginia University, 2012, 2013

The Adam Smith Fellowship, Mercatus Center, 2012 - 2013

\section{Academic Association Memberships:}

American Economic Association

Association of Private Enterprise Education

Public Choice Society

Southern Economics Association

\section{Journal Referee:}

Applied Economics Letters

Applied Economics

Journal of Entrepreneurship and Public Policy

Journal of Private Enterprise

Contemporary Economic Policy 


\section{References:}

Dr. Andrew T. Young

Associate Professor of Economics

P.O. Box 6025

West Virginia University

Office Phone: (304) 293-4526

Email: andrew.young@mail.wvu.edu

Dr. Amanda Ross

Assistant Professor of Economics

P.O. Box 6025

West Virginia University

Office Phone: (304) 293-7869

Email: amanda.ross@mail.wvu.edu
Dr. Joshua C. Hall

Associate Professor of Economics

P.O. Box 6025

West Virginia University

Office Phone: (304) 293-7870

Email: joshua.hall@mail.wvu.edu 